\title{
INVENTÁRIO QUALI-QUANTITATIVO DA ARBORIZAÇÃO E INFRA-ESTRUTURA DAS PRAÇAS DA CIDADE DE VINHEDO (SP)
}

\author{
ISABEL CRISTINA FIALHO HARDER
}

Dissertação apresentada à Escola Superior de Agricultura "Luiz de Queiroz", da Universidade de São Paulo, para obtenção do título de Mestre em Agronomia, Área de Concentração: Fitotecnia.

P I R A C I C A B A

Estado de São Paulo - Brasil

Novembro - 2002 


\section{INVENTÁRIO QUALI-QUANTITATIVO DA ARBORIZAÇÃO E INFRA-ESTRUTURA DAS PRAÇAS DA CIDADE DE VINHEDO (SP)}

\section{ISABEL CRISTINA FIALHO HARDER}

Engenheira Agrônoma

Orientador: Prof. Dr. ROBERVAL DE CÁSSIA SALVADOR RIBEIRO

Dissertação apresentada à Escola Superior de

Agricultura "Luiz de Queiroz", da Universidade de São

Paulo, para obtenção do título de Mestre em

Agronomia, Área de Concentração: Fitotecnia.

P I R A C I C A B A

Estado de São Paulo - Brasil

Novembro - 2002 
Dados Internacionais de Catalogação na Publicação (CIP)

DIVISÃO DE BIBLIOTECA E DOCUMENTAÇÃO - ESALQ/USP

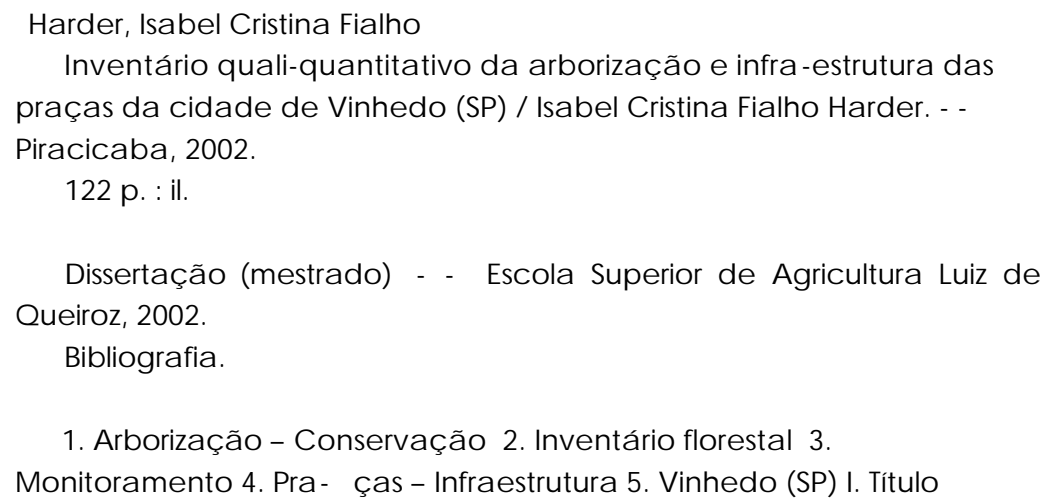

CDD 715.2

\section{"Permitida a cópia total ou parcial deste documento, desde que citada a fonte - $O$ autor"}


À minha mãe, Engenheira Agrônoma Nilva de Oliveira Fialho, pelo amor, dedicação, incentivo e grande contribuição cien tífica.

Ao meu filho Luís Henrique, por ter preenchido minha vida deluz e alegria durante este trabalho.

Ao meu marido Georges, pelo amor, carinho e incentivo nesta jornada.

Ao meu pai Henrique e aos meus padrinhos Alcides e Doris, com muito a mor e saudade.

À minha irmã Ana Silvia, ao meu cunhado Marco e a minha sobrinha Victória pelo, carinho, amizade e companheirismo.

À Eucelina, minha segunda mãe, pela paciência e compreen sã o. 


\section{AGRADECIMENTOS}

A Deus, por ter iluminado o meu caminho, guiando meus passos na direção certa, auxiliando-me a galgar mais um degrau na busca do aprimoramento científico.

Ao Prof. Dr. Roberval de Cássia Salvador Ribeiro, pela atenção, interesse, confiança, amizade e orientação segura no decorrer deste trabalho.

À Prof $^{\mathrm{a}}$. Dr ${ }^{\mathrm{a}}$. Maria Esmeralda Soares Payão Demattê, pela co-orientação, carinho, atenção e pelas valiosas sugestões e correções.

À Universidade de São Paulo, através do Departamento de Produção Vegetal da ESALQ, pela oportunidade da realização deste aprimoramento científico.

Ao CNPq, pelo apoio financeiro.

À Prefeitura Municipal de Vinhedo, em especial ao Exmo. Sr. Prefeito Milton Serafim e ao Secretário de Esporte e Lazer Sr. Odair Fernando Seraphim, pelo apoio logístico.

Aos professores do Departamento de Produção Vegetal, que contribuíram diretamente para minha formação e aprimoramento nos caminhos da Agronomia, ao longo de todos esses anos de convívio.

A todos os colegas e funcionários do curso de pós-graduação em Fitotecnia, pela amizade e companheirismo, os quais tornaram mais agradável esta empreitada.

À banca do exame de qualificação, Prof. Dr. Pedro Jacob Christoffoleti, Prof'. Dr $^{\mathrm{a}}$. Ana Maria Liner Pereira Lima e Prof. Dr. Valdemar Antonio Demétrio, pela valiosas contribuições.

Ao Prof. Dr. Durval Dourado Neto, Coordenador do PPG em Fitotecnia, pela amizade e exemplos profissional e pessoal. 
Aos amigos Dr. Armando Reis Tavares, Ms. Francismar Francisco Alves Aguiar, Bióloga Flávia Gouvea Pozzuto, Ms. Ivan André Alvarez, Dr. José Marcos Barbosa, Prof. Dr. Luís Mauro Barbosa, Ms. Márcia Celestino Macedo, Ms. Roselaine Faraldo Myr Sekiya, Ms. Shoey Kanashiro e Ms. Taís Oetterer de Andrade, pela amizade e confiança, contribuindo com valiosas sugestões.

À futura Bióloga Regina A. Kuhn Munhoz e Engenheira Agrônoma Maria do Carmo Saviello Define, pela amizade, incentivo e valiosa contribuição nos levantamentos de campo e compilação dos dados.

Ao Técnico em Edificações Alexandre Torricelli do Amaral, pela amizade e paciência na digitalização, ilustração e diagramação do Anexo $\mathrm{D}$ e da cópia desse trabalho em CD-ROM.

Ao Dr. Ivan José Antunes Ribeiro, diretor do CAPTA - Frutas de Jundiaí, pela confiança e pelo incentivo.

Aos colegas do Instituto de Botânica, pela amizade e pelo companheirismo.

Aos novos colegas do CAPTA - Frutas de Jundiaí, pelo companheirismo e a oportunidade de novos trabalhos.

Enfim, a todos que, direta ou indiretamente, contribuíram para a realização deste trabalho. 


\section{SUMÁRIO}

Página

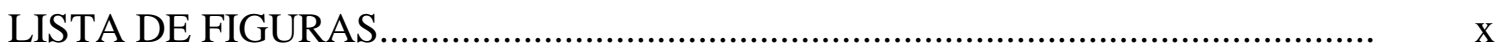

LISTA DE TABELAS...............................................................................

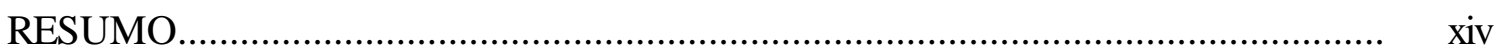

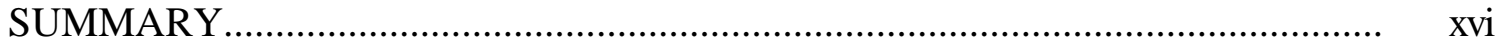

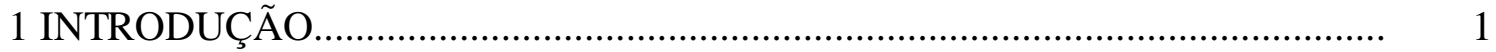

2 REVISÃO DE LITERATURA.......................................................................

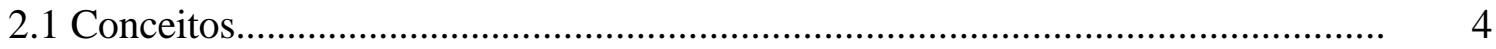

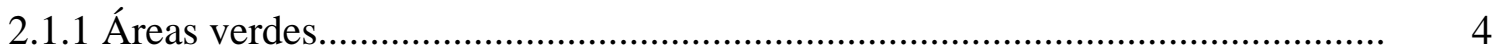

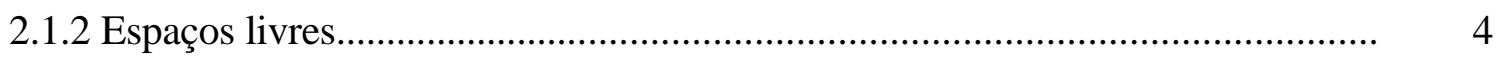

2.1.3 Arborização urbana...................................................................................... 5

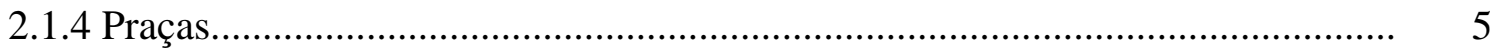

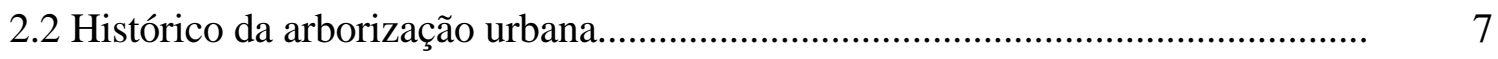

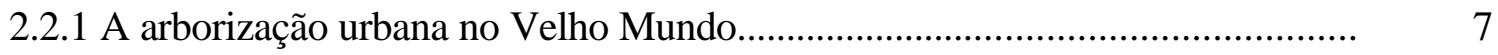

2.2.2 A arborização urbana no Brasil...................................................................... 9

2.2.3 A arborização da capital e do interior do Estado de São Paulo.......................... 9

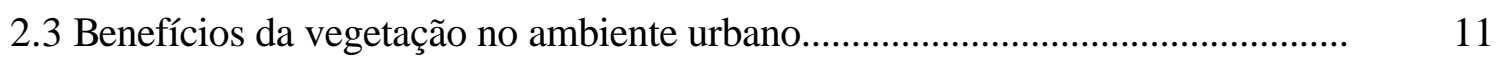

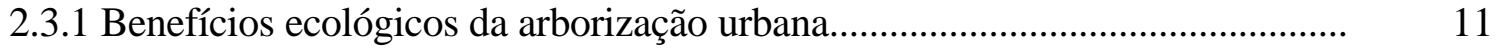

2.3.2 Benefícios estéticos da arborização urbana.................................................... 12

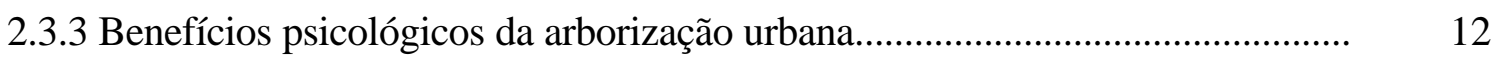

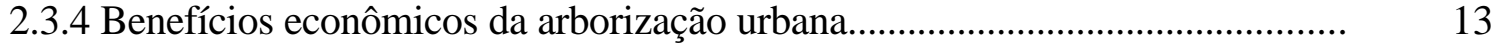

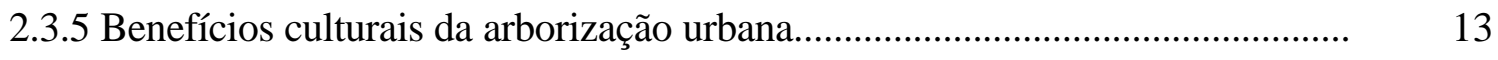

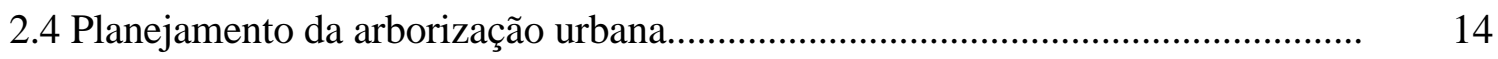

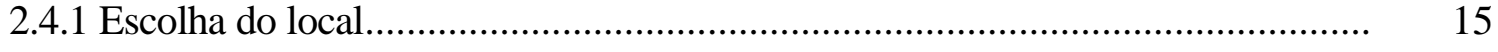

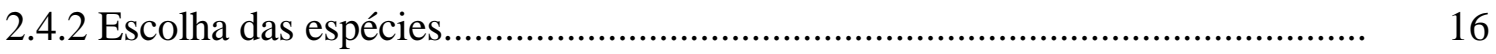


2.4.3 Plano Diretor de Arborização.............................................................................. 21

2.5 Inventário.......................................................................................... 24

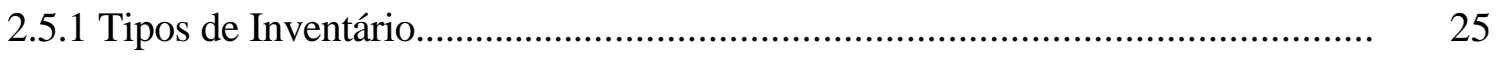

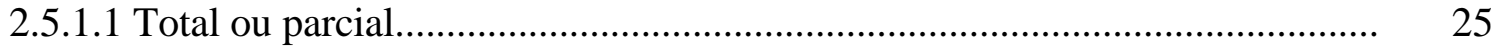

2.5.1.2 Quantitativo, qualitativo ou quali-quantitativo............................................. 25

2.6 Índice de áreas verdes................................................................................... 26

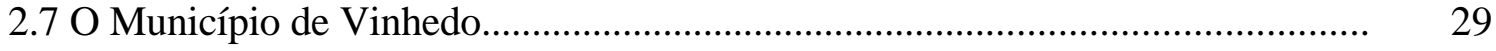

2.7.1 Histórico do Município................................................................................... 29

2.7.2 Praças de Vinhedo..................................................................................... 30

2.7.3 Legislação ambiental municipal........................................................................ 31

3 MATERIAL E MÉTODOS........................................................................... 33

3.1 Caracterização do local................................................................................... 33

3.1.1 Dados físicos......................................................................................

3.1.2 Dados bióticos.......................................................................................... 34

3.1.3 Dados antrópicos..................................................................................... 35

3.2 Diagnóstico........................................................................................... 35

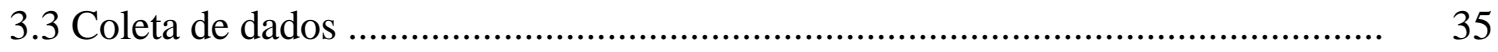

3.3.1 Caracterização dos bairros........................................................................ 36

3.3.2 Codificação dos bairros e praças...................................................................... 37

3.3.3 Inventário da arborização das praças.................................................................. 37

3.3.4 Infra-estrutura das praças............................................................................. 40

3.3.4.1 Estado de conservação de elementos naturais e construídos............................ 41

3.3.4.2 Estado de consolidação da vegetação arbórea.................................................... 43

3.3.5 Outros aspectos observados....................................................................... 43

3.3.6 Classificação das áreas por categorias................................................................. 44

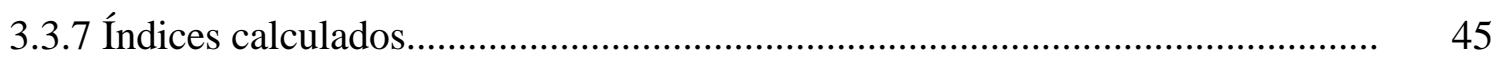

3.3.7.1 Índice de áreas verdes (IAV)..................................................................... 45

3.3.7.1.1 Índice de áreas verdes total (IAVT)..........................................................

3.3.7.1.2 Índice de áreas verdes para parque de vizinhança (IAVPV)........................ 45

3.3.7.1.3 Índice de áreas verdes para parque de bairro (IAVPB)................................. 45 
3.3.7.2 Índice de cobertura vegetal (ICV)..............................................................

3.3.7.3 Índice de áreas verdes utilizáveis (IAVU)......................................................

3.3.7.4 Índice de área verde por bairro (AVB).............................................................. 46

4 RESULTADOS E DISCUSSÃO........................................................................... 47

4.1 Situação geral............................................................................................ 47

4.1.1 Situação das praças..................................................................................... 47

4.1.1.1 Descrição das áreas analisadas......................................................................... 47

4.1.1.1.1 Praça B1P1 (Uderico Reichel)................................................................ 47

4.1.1.1.2 Praça B1P2 (Padre Luiz Sais).................................................................... 48

4.1.1.1.3 Praça B1P3 (sem nome).......................................................................... 48

4.1.1.1.4 Praça B1P4 (Vila João XXIII)................................................................. 48

4.1.1.1.5 Praça B1P5 (Uderico Reichel)................................................................... 49

4.1.1.1.6 Praça B2P1 (Aquário)............................................................................ 49

4.1.1.1.7 Praça B2P2 (sem nome)...................................................................... 50

4.1.1.1.8 Praça B3P1 (Dom Martinho Albert Roth)................................................... 50

4.1.1.1.9 Praça B3P2 (da Vitória)........................................................................ 50

4.1.1.1.10 Praça B4P1 (da Biquinha).................................................................. 51

4.1.1.1.11 Praça B4P2 (Comendador Paulo Storani)................................................ 51

4.1.1.1.12 Praça B5P1 (Sant'Ana)......................................................................... 51

4.1.1.1.13 Praça B5P2 (Centro de Convivência)........................................................ 52

4.1.1.1.14 Praça B5P3 (Corazzari) ........................................................................ 52

4.1.1.1.15 Praça B5P4 (sem nome) ..................................................................... 53

4.1.1.1.16 Praça B5P5 (sem nome)....................................................................... 53

4.1.1.1.17 Praça B6P1 (Prefeito Jair Mendes de Barro)............................................... 53

4.1.1.1.18 Praça B6P2 (sem nome).................................................................... 53

4.1.1.1.19 Praça B6P3 (sem nome)....................................................................... 54

4.1.1.1.20 Praça B6P4 (sem nome)...................................................................... 54

4.1.1.1.21 Praça B7P1 (sem nome)....................................................................... 54

4.1.1.1.22 Praça B8P1 (Centro de lazer do trabalhador "Aurora Sudário")................ 59

4.2 Situação da arborização................................................................................... 59 


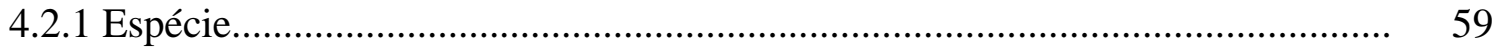

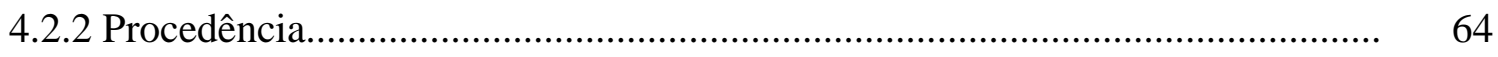

4.2.3 Conformação geral..................................................................................... 65

4.2.3.1 Ocorrência de podas................................................................................... 67

4.2.3.2 Altura da primeira bifurcação...................................................................... 68

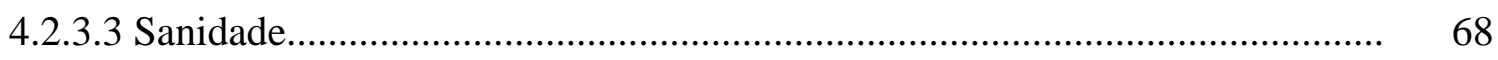

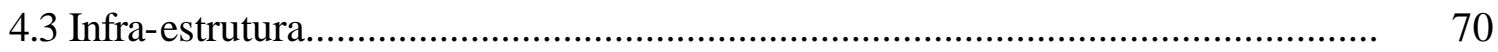

4.3.1 Limpeza e estado de conservação de elementos naturais e construídos............. $\quad 75$

4.3.2 Estado de consolidação da vegetação arbórea..................................................... 78

4.3.3 Classificação das praças em categorias.............................................................. 79

4.4 Índices calculados........................................................................................ 81

4.4.1 Índice de cobertura vegetal....................................................................... 81

4.4.2 Índice de áreas verdes...................................................................................... 82

4.4.2.1 Índice de áreas verdes total (IAVT) ........................................................... 82

4.4.2.2 Índice de áreas verdes para parque de vizinhança (IAVPV)............................ 83

4.4.2.3 Índice de áreas verdes para parque de bairro (IAVPB)................................... 83

4.4.3 Índice de áreas verdes utilizáveis (IAVU)....................................................... 84

4.4.4 Índice de área verde por bairro (AVB).......................................................... 84

4.5 Setorização de bairros.................................................................................... 85

4.6 Correlação entre o nível sócio-econômico do bairro e a arborização de praças... 86

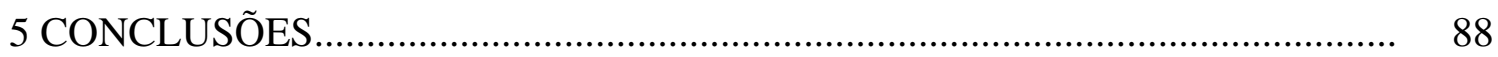

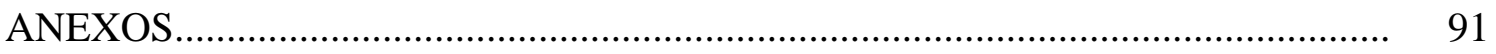

REFERÊNCIAS BIBLIOGRÁFICAS.............................................................. 96

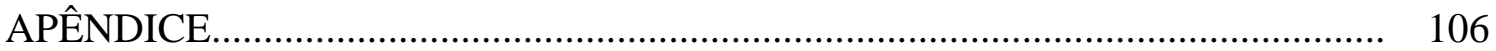




\section{LISTA DE FIGURAS}

Página

1 Localização do município de Vinhedo, no Estado de São Paulo....................... 33

2 Mapa da cobertura vegetal natural do Município de Vinhedo.......................... 34

3 Estrutura da prancheta dendrométrica..................................................... 40

4 Aspecto geral das praças B1P1 (Uderico Reichel); B1P2 (Padre Luiz Sais), B1P3 (sem nome), B1P4 (Vila João XXIII), B1P5 (Uderico Reichel) e B2P1 (Aquário) da cidade de Vinhedo (SP), 2002.

5 Aspecto geral do "playground" da praça B2P1 (Aquário) e aspecto geral das praças B2P2 (sem nome), B3P1 (Dom Martinho Albert Roth), B3P2 (da Vitória), B4P1 (Biquinha) e B4P2 (Comendador Paulo Storani) da cidade de Vinhedo (SP), 2002.

6 Aspecto geral das praças B5P1 (Sant'Ana), B5P2 (Centro de Convivência), B5P2a (Centro de Convivência), B5P3 (Corazzari), B5P4 (sem nome) e B5P5 (sem nome) da cidade de Vinhedo (SP), 2002.

7 Aspecto geral das praças B6P1 (Prefeito Jair Mendes de Barros), B6P2 (sem nome), B6P3 (sem nome), B6P4 (sem nome), B7P1 (sem nome) e B8P1 (Centro de lazer do trabalhador "Aurora Sudário") da cidade de Vinhedo (SP), 2002.

8 Freqüência de espécies distribuídas por bairro e classificadas em nativas e exóticas, presentes na cidade de Vinhedo (SP), 2002

9 Conformação geral das árvores, expressos em percentagem, presentes nas praças existentes nos bairros inventariados da cidade de Vinhedo (SP), 2002 .

10 Tipos de podas executadas nas árvores dos diferentes bairros (B1 a B8) das praças da cidade de Vinhedo (SP), 2002. 
11 Altura da primeira bifurcação observada em árvores existentes nas praças 68 dos diferentes bairros (B1 a B8) da cidade de Vinhedo (SP), 2002.................

12 Grau de sanidade apresentado pelas árvores existentes nas praças dos diferentes bairros (B1 a B8) da cidade de Vinhedo (SP), 2002 ........................ 


\section{LISTA DE TABELAS}

Página

1 Espécies recomendadas para arborização urbana no Estado de São Paulo em locais anteriormente revestidos por vegetação de cerrado, apresentando espécie; dados de porte (pequeno $=\mathrm{P}$ : abaixo de $12 \mathrm{~m}$ de altura; médio $=\mathrm{M}$ : de 12 a $18 \mathrm{~m}$ de altura; grande = G: acima de 18m de altura); velocidade de crescimento (rápido: mais que $1 \mathrm{~m}$ em um ano; regular: $1 \mathrm{~m}$ em um ano; lento: menos de $1 \mathrm{~m}$ em um ano); informações fenológicas.

2 Espécies arbóreas recomendadas para utilização em áreas urbanas, com ocorrência em Cerrado, apresentando: nome científico; porte (pequeno $=\mathrm{P}$ : menos de $5 \mathrm{~m}$ de altura; médio = M: entre 5 a $10 \mathrm{~m}$ de altura; grande $=\mathrm{G}$ : mais de $10 \mathrm{~m}$ de altura); deciduidade; desenvolvimento no campo (lento: menos de $2 \mathrm{~m}$ em dois anos; moderado: 2 a $3 \mathrm{~m}$ em dois anos; rápido: mais de $3 \mathrm{~m}$ em dois anos); cor da flor e do fruto.....

3 Sugestão de índices urbanísticos para espaços livres.

4 Codificação e denominação dos bairros e praças existentes na cidade de Vinhedo, 2002.

5 Espécies inventariadas em todas as praças de Vinhedo (SP), quantidade de indivíduos por espécie e sua freqüência (expressa em percentagem), no ano 2002

6 Espécies de maior freqüência, expressa em percentagem, observadas nas praças de Vinhedo (SP), 2002.

7 Espécies arbóreas com frequiência acima de 10\%, presentes nos diferentes bairros da cidade de Vinhedo (SP), 2002.

8 Freqüência das espécies por praças, classificadas em nativas, exóticas e não identificadas, na cidade de Vinhedo (SP), 2002. 
9 Grau de sanidade (expresso em percentagem) das árvores, classificado como saudável, recuperável e irrecuperável nas praças da cidade de Vinhedo (SP), 2002

10 Existência de pavimentação, iluminação, equipamentos e construções (expressos em percentagem) nas praças dos diferentes bairros (B1 a B8) da cidade de Vinhedo (SP), 2002.

11 Existência de pavimentação, iluminação, equipamentos e construções nas praças dos diferentes bairros (B1 a B8) da cidade de Vinhedo (SP), 2002

12 Relação das praças da cidade de Vinhedo (SP) com seus equipamentos, 2002

13 Limpeza e estado de conservação de elementos naturais e construídos das praças do município de Vinhedo (SP), 2002 (dados em percentagem).

14 Valores médios de CAP (circunferência a altura do peito) e altura das árvores $(\mathrm{H})$ inventariadas e estado de consolidação das praças, na cidade de Vinhedo (SP), 2002

15 Estado de consolidação da vegetação arbórea das praças dos bairros de Vinhedo (SP), 2002.

16 Área total e classificação por categoria das praças existentes nos diferentes bairros da cidade de Vinhedo (SP), 2002.

17 Áreas das praças classificadas em parques de vizinhança e de bairro, nos diferentes bairros estudados na cidade de Vinhedo (SP), 2002.

18 Índice de área verde por bairro obtido nas praças dos diferentes bairros da cidade de Vinhedo (SP), 2002

19 Localização dos bairros dentro da setorização, indicando a quantidade de praças e sua área de cobertura vegetal arbórea, na cidade de Vinhedo (SP), 2002

20 Correlação por bairro da freqüência de praças, frequiência total de árvores, área de cobertura vegetal arbórea existente nas praças e custo médio do metro quadrado de terreno, na cidade de Vinhedo (SP), 2002. 


\title{
INVENTÁRIO QUALI-QUANTITATIVO DA ARBORIZAÇÃO E INFRA- ESTRUTURA DAS PRAÇAS DA CIDADE DE VINHEDO (SP)
}

\author{
Autora: ISABEL CRISTINA FIALHO HARDER \\ Orientador: Prof. Dr. ROBERVAL DE CÁSSIA SALVADOR RIBEIRO
}

\section{RESUMO}

O inventário das espécies arbóreas e da infra-estrutura das praças da cidade de Vinhedo, foi efetuado verificando-se inclusive os equipamentos oferecidos e o estado geral de conservação. Os levantamentos foram feitos no perímetro urbano, excetuandose os condomínios, as áreas de parques e as de preservação de mananciais. Para a caracterização dos bairros, foram utilizados dois parâmetros: a setorização adotada pela prefeitura e planta de valores imobiliários. Foi realizado o inventário da vegetação arbórea, no qual foram considerados apenas os indivíduos com CAP (circunferência à altura do peito) acima de $10 \mathrm{~cm}$ e foram levantadas as seguintes informações: nomes comum e científico das espécies; CAP; altura; aspecto geral; diâmetro de copa; latitude e longitude por meio de GPS; presença de pragas, doenças ou parasitas; ocorrência de podas (drástica e/ou de condução); fitossanidade da raiz, tronco e copa. Nas praças, os itens analisados foram: nome da praça, localização, área total de cada praça, número total de árvores e elementos arquitetônicos. Foram levantadas 22 praças, totalizando 764 indivíduos divididos em 23 famílias botânicas, com 55 espécies além de 32 espécies que não foram identificadas até o momento. A espécie de maior ocorrência foi Syagrus romanzoffiana (jerivá), com 31,94\%. Em 63,64\% das praças, menos de $50 \%$ das 
espécies eram exóticas. A maior parte dos indivíduos apresentou aspecto geral normal, demostrando prática de tratos culturais adequados. Na maioria dos casos, as podas foram feitas corretamente, ou não houve a necessidade de nenhuma intervenção. Do total de 22 praças, apenas cinco apresentaram bom estado geral de conservação tanto dos elementos naturais, como dos construídos. Em 68,18\% das praças da cidade, foram encontradas árvores com altura superior a $6 \mathrm{~m}$, mostrando que eram áreas que necessitavam apenas de procedimentos de manutenção de rotina. Por outro lado $22,72 \%$ das praças necessitavam de práticas de manutenção mais direcionadas ao desenvolvimento das árvores, tais como adubações periódicas, capina, podas de condução. Finalmente, em 13,64\% das praças deveriam ocorrer intervenções tanto de manutenção, como de recuperação por meio de novos plantios, ou mesmo, de planejamento para remodelação da área. A cidade de Vinhedo apresentou carência de praças em muitos bairros, pois, dos 31 existentes, apenas oito possuíam alguma área disponível. Os bairros localizados no setor S2 (áreas próximas ao centro ou em bairros onde há apenas comércio local) possuíam maior percentagem de praças $(40,91 \%)$ e de cobertura vegetal $\left(19.466,04 \mathrm{~m}^{2}\right)$. Esses bairros apresentaram arborização melhor que a dos outros setores, principalmente em relação aos localizados em áreas predominantemente industriais, como é o caso de S4. Foi possível observar que a arborização está diretamente ligada ao valor do imóvel. As praças com melhor estado de conservação estavam localizadas em bairros de maior nível sócio-econômico. A cidade de Vinhedo apresentou os seguintes índices cobertura vegetal: $0,55 \mathrm{~m}^{2}$ de copa/habitante; áreas verdes: $2,19 \mathrm{~m}^{2}$ de praça/habitante; áreas verdes para parque de vizinhança: $0,65 \mathrm{~m}^{2}$ de parque de vizinhança/habitante; áreas verdes para parque de bairro: $1,55 \mathrm{~m}^{2}$ de parque de bairro/habitante; áreas verdes utilizáveis: $1,95 \mathrm{~m}^{2}$ de praças utilizáveis/habitante e área verde por bairro: $0,1633 \mathrm{~m}^{2}$ de praças/bairro. 


\title{
QUALI-QUANTITATIVE SURVEY OF THE ARBORIZATION AND INFRASTRUCTURE OF THE SQUARES OF THE CITY OF VINHEDO (SP)
}

\author{
Author: ISABEL CRISTINA FIALHO HARDER \\ Adviser: Prof. Dr. ROBERVAL DE CÁSSIA SALVADOR RIBEIRO
}

\section{SUMMARY}

A quali-quantitative survey of the tree species and the general state of the infrastructure of the squares was carried out at the city of Vinhedo. The surveys were made in the urban area, excepting the private housing estates, as well as areas of parks and natural resources. The inventory of the trees was carried out by selecting only individuals with trunk (circumference at the height of $1.30 \mathrm{~m}$ ) in excess of $10 \mathrm{~cm}$. The following parameters were assessed: common and scientific names of the species; trunk circumference at $1.30 \mathrm{~m}$; height; general state; tree-top diameter; latitude and longitude by means of GPS; presence of plagues, diseases or parasites; occurrence and type of pruning (drastic and/or of training); sanitary state of roots, trunks and tree-tops. Regarding the squares it was also analyzed: name of the square, location, total area of each square, total number of trees and architectural elements. Two parameters were also used for the characterization of the squares: the borough system, as adopted by the city prefecture and the real value of the estates. A total of 22 squares have been surveyed, making up to 764 individuals, comprising 23 botanical families, 55 species, not including 32 species which have not been identified yet. The species of higher frequency showed to be the palm Syagrus romanzoffiana with $31,94 \%$ of the individuals. Less than $50 \%$ of the species were exotic in $63,64 \%$ of the squares. The majority of the individuals 
showed good general state, where pruning has been made correctly or did not have the need to be made. Out of 22 squares only 5 were found to be in good state of conservation for both natural and constructed elements. In $68,18 \%$ of the squares trees were taller than $6 \mathrm{~m}$, only feasible to routine maintenance, whilst $22.72 \%$ of the squares were in need of better management for the proper development of the trees such as: periodic fertilizations, weeding, prunings tarining; and finally $13.64 \%$ of the squares were in need of better maintenance, new planting or planning for renovation. The city of Vinhedo showed a lack of squares in many boroughs. Out of 31 boroughs only 8 had squares. Squares located in sector S2 (areas near to the city center or with local shops), have showed the largest percentage of squares (40,91\%) and plant coverage $\left(19.466,04 \mathrm{~m}^{2}\right)$. These borough had a better arborization when compared to those found in predominantly industrials areas, such as S4. It was possible to observe that the arborization is directly related to the value of the property. The squares with better arborization were located in boroughs with higher priced estates. The following indexes were found for the city of Vinhedo: plant coverage - $0,55 \mathrm{~m}^{2}$ tree-top/inhabitant; green areas - $2,19 \mathrm{~m}^{2}$ of square/inhabitant; green areas per neighborhood park - $0,65 \mathrm{~m}^{2}$ neighborhood park/inhabitant; green areas per park of borough - $1,55 \mathrm{~m}^{2}$ park of borough/inhabitant; utilizable green areas - 1,95 $\mathrm{m}^{2}$ usable squares/inhabitant and green area per borough $0,1633 \mathrm{~m}^{2}$ square/ borough. 


\section{INTRODUÇÃO}

A crise ambiental do mundo tem sido amplamente discutida; porém, a questão do ambiente urbano é relegada a segundo plano tanto na teoria quanto na prática dos movimentos ambientalistas e ecológicos (Busarello, 1990).

$\mathrm{O}$ crescimento desordenado que a maioria das cidades brasileiras tem apresentado nas últimas décadas e a ocupação irregular do solo têm dificultado a execução de planejamentos adequados que viabilizem uma integração da área construída com a vegetada, sejam estas naturais ou mesmo artificiais, provocando uma significativa queda de qualidade de vida, principalmente nos grandes centros (Bianchi \& Graziano, 1992; Detzel, 1992).

A ocupação dos espaços na malha urbana, de forma desordenada, nem sempre propicia a reserva de áreas destinadas à implantação de praças e parques. Não existe a correspondente relação entre a necessidade do homem moderno de espaços para fins recreativos e de lazer e sua disponibilidade (Santos \& Teixeira, 2001).

A arborização urbana caracteriza-se como um dos mais importantes elementos que compõem o ecossistema das cidades e que, pelos benefícios que produz, deveria ser uma preocupação permanente de todo e qualquer planejamento urbano (Veras, 1986).

O plantio de árvores no desenho urbano deve ser planejado dando especial atenção aos aspectos culturais e de memória da cidade, harmonizando-os com as necessidades ecológicas e de preservação da diversidade biológica (São Paulo, s.d.).

Nos últimos dez anos, o município paulista de Vinhedo vem sofrendo alteração no desenvolvimento urbano, causada, principalmente, pelo aumento da sua população, composta hoje, em grande parte, por indivíduos vindos de São Paulo, que, a princípio, possuíam casas para lazer e que hoje passaram a residir na cidade. 
O número de condomínios e residências tem crescido rapidamente, causando forte impacto na vegetação da região. De acordo com Milano \& Dalcin (2000), deve-se considerar a existência de benefícios econômicos e sociais das árvores nas cidades, quer sejam de ordem ecológica (clima e poluição), biológica (saúde física do homem) ou psicológica (saúde mental do homem). Os benefícios econômicos indiretos, segundo Grey \& Deneke (1978), podem ser sentidos na valorização de áreas e imóveis pela presença da vegetação.

A arborização torna-se mais importante no contexto urbano à medida que as cidades crescem verticalmente ou se expandem horizontalmente. Nos dois casos, a artificialização do meio urbano e suas consequiências na qualidade ambiental são facilmente percebidas pela população que vem sofrendo seus efeitos, tornando-se, a cada dia, mais consciente dessa situação (Motta, 1998). A arborização contribui também para caracterizar e dar identidade e qualidade aos espaços nos seus diversos níveis de complexidade, criando referenciais simbólicos ou reforçando aqueles já existentes (Busarello, 1990).

Segundo Soares (1998), uma arborização correta e harmoniosa, ao mesmo tempo em que espelha a cultura e o grau de civilização de uma cidade, constitui-se num dos mais sólidos elementos de sua valorização.

A cobertura vegetal, ao contrário de muitos outros recursos físicos da cidade, é relacionada, pela maioria dos cidadãos, mais como uma função de satisfação psicológica e cultural do que com funções físicas (Nucci, 2001).

A arborização das praças da cidade de Vinhedo contribui de forma significativa para o total da área verde pública. Grande parte dessas áreas é utilizada para lazer, principalmente por crianças e idosos, e apresenta, em sua grande maioria, espécies arbóreas.

Avaliações periódicas, por meio de inventários, são de extrema importância para determinar as características atuais da arborização, não estando este tipo de atividade necessariamente relacionado a locais com implantações inadequadas ou sem critérios de manutenção, e sim, a quaisquer locais arborizados. Considerando essa situação, o monitoramento, que resulta de avaliações sistemáticas, pode atingir objetivos tais como: 
programas de poda para evitar problemas com fiação; identificação de espécies promissoras; realização de controle fitossanitário; determinação de benefícios; necessidades de aprimoramento das técnicas de tutoramento (Milano et al., 1992b).

Hoje, o plantio de árvores no espaço urbano já não pode ser realizado de forma amadorística, e as necessidades urbanas a serem mitigadas passam, além do estético, pelo psicológico, econômico, social e político. Essa visão mais globalizante e essa necessidade técnica de amenizar problemas tão variados fazem com que seja procurado um termo mais abrangente: floresta urbana. Hoje, árvores enfileiradas já não são suficientes para a melhoria da qualidade vida e, desde o século passado, já por imposição da industrialização, o homem vem procurando aumentar a massa arbórea no tecido urbano com a criação dos parques municipais e metropolitanos. Assim, a diferença básica entre a arborização urbana e a floresta urbana está na mudança de visão do elemento árvore, de individual para coletivo (Gonçalves, 2000).

Sob estas considerações, o objetivo do presente trabalho consistiu em avaliar a qualidade física das praças do município de Vinhedo (SP) e sua arborização, utilizando procedimentos metodológicos que possibilitaram a identificação e análise das praças. Pretendeu-se, ainda, formar uma base de dados para o planejamento ou replanejamento das estruturas e arborização desses locais.

Com a aplicação dos procedimentos metodológicos, tornou-se possível:

- efetuar um diagnóstico da situação geral das praças, seu estado de conservação, da infra-estrutura existente e arborização;

- definir formas de acompanhamento e, ou, monitoramento das áreas existentes;

- proporcionar subsídios para elaboração de planos de arborização das praças sobre bases técnico-científicas. 


\section{REVISÃO DE LITERATURA}

\subsection{Conceitos}

\subsection{1 Áreas verdes}

"Área verdes" é um termo geral que se aplica a diversos tipos de espaços urbanos que têm em comum: serem abertos (ao ar livre); serem acessíveis; serem relacionados com saúde e recreação ativa e passiva e proporcionam interação das atividades humanas com o meio ambiente (Geiser et al., 1976; Demattê, 1997).

São consideradas áreas verdes tanto áreas públicas como particulares. Podem ser representadas por uma paisagem natural pouco alterada no seu estado original, ou uma paisagem quase inteiramente artificial, com pouca evidência de jardinagem ou arborização. São espaços tipicamente abertos, não ocupados completamente por prédios ou outras estruturas construídas. Podem ser jardins, praças, parques, bosques, alamedas, balneários, campings, praças de esporte, "playgrounds", "playlots", cemitérios, aeroportos, corredores de linhas de transmissão, faixas de domínio de vias de transporte, margens de rios e lagos. Desde que devidamente tratados, também se incluem os depósitos abandonados de lixo, as áreas de tratamento de esgoto e outros espaços semelhantes. (Demattê, 1997).

\subsubsection{Espaços livres}

São espaços livres as áreas não construídas e não destinadas a grandes infraestruturas, no interior e nas proximidades dos setores reservados à construção (Lapoix, 1979).

Lima et al. (1994) citaram que outro termo muito utilizado é o traduzido do inglês "open space", espaço aberto, e que, ainda na década de 60 , foi considerado como 
uma área monitorada para a produção ou preservação de recursos naturais, para incremento da saúde, para bem-estar, conforto, segurança pública, corredores, e de expansão urbana. Segundo os autores, o conceito mais abrangente é o de espaço livre, integrando os demais e contrapondo-se ao espaço construído, em áreas urbanas. Segundo Cavalheiro \& Del Picchia (1992), do ponto de vista conceitual, uma área verde é sempre um espaço livre. Entre os espaços livres, temos assim as áreas verdes, onde há o predomínio de vegetação arbórea, e que englobam as praças, os jardins públicos, os parques urbanos, os canteiros centrais e trevos de vias públicas, todos com funções estética e ecológica; entretanto as árvores das vias públicas não devem ser consideradas como tal, porque não apresentam distribuição em maciços (Lima et al. 1994).

\subsubsection{Arborização urbana}

Define-se arborização urbana como o conjunto de áreas públicas ou privadas com cobertura arbórea natural ou cultivada que uma cidade apresenta. Podem ser inseridas, ainda, as áreas verdes com cobertura não arbórea (Grey \& Deneke, 1978; Sanchotene, 1994).

Kirchner et al. (1990) subdividiram o termo arborização urbana em três setores: áreas verdes públicas, áreas verdes privadas e arborização de ruas. No entanto, comentaram que a simples existência desses três setores não caracteriza um sistema de arborização urbana, devendo, para tanto, existir um adequado planejamento capaz de organizar os setores e normatizar o seu uso.

\subsubsection{Praças}

Praças são espaços livres urbanos utilizados como local público. São pontos de encontro cuja principal função é de incentivar a vida comunitária e o lazer. (Lima et al., 1994; Demattê, 1997).

São áreas verdes com dimensões, em geral, entre $100 \mathrm{~m}^{2}$ e 10 hectares, porém não se pode padronizar a praça quanto ao tamanho sem conhecer antes o seu entorno (Demattê, 1997; Porto Alegre, 2001). 
Podem ser distinguidos dois tipos de praças: o espaço vazio que restou depois da construção dos edifícios e o espaço aberto planejado. São exemplos do primeiro tipo as praças medievais, onde não há vegetação. Do segundo tipo, ocorre a praça planejada, onde o elemento vegetal passa a ser valorizado, assim como qualquer outro fator de conforto e ornamentação. (Longhi et al., 2001; Demattê, 1997).

As praças podem ser dotadas ou não de vegetação. Quando não possuem vegetação, são chamadas de praças secas e, no caso de terem vegetação, são consideradas jardins (Lima et al., 1994; Porto Alegre, 2001).

Segundo Chimenti (2001), as concepções modernas do uso de espaços livres caracterizam uma nova formação da praça pública, em que foram gradativamente introduzidos itens como o lazer infantil e as atividades esportivas. A disposição da vegetação é um fator importante no que se refere à qualidade dos projetos, já que serve como elemento de formação de espaços.

Em geral, as praças são projetadas sob o aspecto funcional, no que tange ao traçado e materiais, relevando a importância dos elementos vegetais nesses ambientes, não só como estruturadores, mas como responsáveis por efeitos de cor, aroma, sombra, luz, brilho e mobilidade (Santos \& Teixeira, 2001).

Por fazer parte da vida comunitária, a praça reflete os costumes, as crenças e outros aspectos da cultura de seus usuários. Planejada ou não, ela tem valores simbólicos ligados aos seus freqüentadores. (Demattê, 1997).

$\mathrm{Na}$ cidade de Vinhedo, algumas das áreas destinadas a praça seguem as concepções modernas, detectadas pela presença de "playgound" e áreas para esportes. Porém, a existência constante de bancos mostra preocupação com o uso dos espaços para o lazer passivo. A vegetação é utilizada como delimitador de espaços, ficando restrita, em sua maior parte, a canteiros. Esses espaços também refletem as características e o interesse da comunidade do entorno, principalmente pela intensidade de uso e estado de conservação das áreas. 


\subsection{Histórico da arborização urbana}

Ao longo da História, pode-se verificar que os espaços abertos e públicos sofreram transformações no seu conceito e na expressão formal e espacial, principalmente quanto ao modo de ver a paisagem urbana, ao tratamento e a cultura desses locais. Em diversos momentos, a praça apresentou-se como espaço de mercado, local de culto, de esporte e político. (Porto Alegre, 2001).

Em 1850, muitos cidadãos americanos eram fazendeiros, com $20 \%$ da população morando nas cidades. Em 1920, 50\% da população era urbana, composta por famílias rurais e imigrantes recém-chegados. Hoje, somente $3 \%$ da população tem o compromisso de produzir comida, e mais de $80 \%$ dos americanos podem ser classificados como urbanos. (Miller, 1996).

A utilização de árvores como elemento componente do meio urbano não é recente. A importância estética e até espiritual das árvores foi registrada na história da civilização pelos egípcios, fenícios, persas, gregos, chineses e romanos, compondo jardins e bosques sagrados, destacando e emoldurando templos, e determinando conhecimentos rudimentares sobre as árvores e sua manutenção. (Milano \& Dalcin, 2000).

\subsubsection{A arborização urbana no Velho Mundo}

Nas cidades gregas do século VI a.C, a estrutura de ocupação do espaço refletia o sistema político vigente. A cidade articulava-se em torno da Ágora (praça central), que tinha a função de congregar a população, para que se pudesse discutir a política da república. Reunia também templos das diversas divindades que, ao contrário do que muitos acreditam, eram arborizados. Suas árvores eram uma homenagem aos deuses que representavam e, certamente, tinham a função de melhorar as condições microclimáticas, pois eram de grande porte e proporcionavam sombreamento intenso, podendo amenizar as temperaturas locais. (Lima et al., 1994; Demattê, 1997).

O Fórum Romano apresentava o produto típico da arquitetura urbana, cercada de monumentos e estátuas, sendo o local onde se erguiam os edifícios públicos mais 
significativos. Os jardins eram poucos e privativos, mas muito freqüentados pelos que tinham acesso às mansões. (Porto Alegre, 2001).

$\mathrm{Na}$ Renascença, a praça e a estrutura urbana passaram a adaptar-se uma à outra, e foi nesse período que surgiram as cidades burguesas (Porto Alegre, 2001). O homem passou a buscar e cultivar espécies trazidas de outras regiões, colecionadas e exibidas nos jardins botânicos (Milano \& Dalcin, 2000).

No período barroco, a praça era formada de planos estabelecidos por eixos, ressaltando infinitos caminhos, pela sua monumentalidade e traçados radio-concêntricos. As formas geométricas e a escala enorme fizeram com que a praça barroca se abrisse de forma espacial para a cidade. (Porto Alegre, 2001).

O jardim público, que tem alguns exemplos já no século XVIII, projetou-se de modo intenso, pois a população urbana necessitava de espaços verdes para o lazer e o contato com a natureza. $\mathrm{O}$ afastamento do habitante da cidade das suas origens naturais, do contato com o campo, gerou essa intensificação da nostalgia em relação à vegetação. (Terra, 2000).

Por volta de 1700, as árvores passaram a ser cada vez mais marcantes nas cidades, principalmente como elemento da composição urbana e, finalmente, marcando presença nas "urbes" por volta de 1800, com os "squares" de Londres e os "boulevards" de Paris, seguindo até os dias de hoje como componentes obrigatórios do ambiente urbano (Grey \& Deneke, 1978; Milano \& Dalcin, 2000). Nesse período, cidades como Paris e Berlim, respectivamente, sofreram uma total reforma urbana por obra dos paisagistas Haussmann e Lenne, com a oferta de Parques, Alamedas e "Promenades" para a população (Lima et al., 1994).

Até a Revolução Industrial, as áreas verdes tinham uma função de representação para as autoridades e aristocracia, mas não existiram, com esse caráter, durante toda a Idade Média (Lima et al., 1994). Nesse mesmo período, as praças eram a expressão física da urbanização e, nas cidades fortificadas, eram implantadas em áreas vazias que ficavam espalhadas entre as construções, muito próximas, para atividades coletivas da cidade (Porto Alegre, 2001). 
A praça é um espaço ancestral que se confunde com a própria origem do conceito ocidental urbano (Segawa, 1996). O mesmo não se pode afirmar do jardim ou do parque públicos, criações efetivamente materializadas a partir do século 17, quando apareceram os parques arborizados (Porto Alegre, 2001).

\subsubsection{A arborização urbana no Brasil}

Um dos primeiros jardins públicos do Brasil foi o Passeio Público do Rio de Janeiro, construído em 1779 para servir população da cidade (Terra, 2000). Embora destinado a um público restrito, pois era circundado por um muro, o Passeio Público carioca foi o primeiro jardim estruturado às proximidades do contexto urbano e éz parte de uma série de outros, como os de Belém, Olinda, Vila Rica e São Paulo (Goya, 1992).

Em 1808, foi criado o Real Horto (atual Instituto de Pesquisa Jardim Botânico do Rio de Janeiro) com a finalidade de aclimatação e cultivo de especiarias vindas da Índia. Porém, só a partir de 1822 a visitação da área, até então privilégio da corte, foi aberta ao público em geral. (Milano \& Dalcin, 2000).

\subsubsection{A arborização da capital e do interior do Estado de São Paulo}

O manejo da vegetação pelo homem europeu na cidade de São Paulo remonta à sua fundação, inicialmente com os jesuítas, que plantaram, junto a sua própria igreja, plantas trazidas da Europa cultivadas ao lado de espécies indígenas (Goya, 1992).

A cidade colonial paulista, por seu próprio traçado, com ruas estreitas e edificações sem recuos frontais ou laterais, não permitia a arborização de suas vias. Com a Proclamação da Independência em 1822, na capital paulista, o hábito de passear ao ar livre teve seu início principalmente com as apresentações em espaços abertos e com a utilização do Passeio Público. (Goya, 1992).

As praças públicas eram todas acanhadas e irregulares, destacando-se apenas as do Palácio (Pátio do Colégio), da Sé e da Câmara Municipal. Por volta de 1840, notavase uma mudança no comportamento em relação ao tratamento dos espaços públicos, com jardins e alguma arborização, por meio da remodelação do Jardim Público e, 
principalmente, da arborização, pavimentação e iluminação das ruas da cidade (Goya, 1992).

Além da experiência pioneira do "Jardim Botânico", depois "Passeio Público", na cidade de São Paulo, as árvores apareceram primeiramente nas praças. Somente na segunda metade do século XIX apareceram na arborização de ruas, ainda que, muitas vezes, pela mão de particulares. (Goya, 1992).

Entre 1900 e 1930, várias obras foram inauguradas em São Paulo, destacando-se a Praça da Luz, o Parque Dom Pedro II, os Jardins do Ipiranga, o Parque Trianon, o Parque do Anhangabaú, a Praça Ramos de Azevedo, o Parque da Água Branca e o Horto Florestal. Nessa época, iniciou-se também a recuperação da área que viria a se tornar o Parque do Ibirapuera. (Braga, s.d.).

Com o crescimento da cidade, esse conjunto extremamente bem articulado foi desfigurado, com o alargamento de vias e a retirada da arborização. Mesmo parques como o Anhangabaú sucumbiram ao automóvel já nos anos trinta, e o Parque Dom Pedro II, na década de 50. (Goya, 1992).

Nos anos 40 e 50, muitas famílias passaram a residir em prédios de apartamentos. A praça-jardim não desapareceu, porém ir à praça deixou de ser um hábito de todos, para se tornar um hábito de segmentos e faixas etárias. Os coretos não eram mais necessários, as formas de lazer diversificaram-se e eram aceitos apenas uns poucos elementos decorativos. A disposição da vegetação tornou-se totalmente diversa em relação ao passado, as árvores delimitavam o contorno das praças e criaram-se espaços abertos e fechados. Essa praça sempre continha "playground", quadra ou quadras poliesportivas, espelhos d'água e, eventualmente, uma arena, que, de certo modo, substituiu o antigo coreto. Esses projetos passaram a ser concebidos dentro de uma receita padrão e, muitas vezes, não avaliavam as verdadeiras necessidades da comunidade a que se pretendia atender. (Macedo, 1999).

O café foi responsável, direta e indiretamente, pela ocupação de maior parte do território paulista, atingindo, em fins do século XIX, além de todo o Vale do Paraíba, a região de Campinas, de onde se irradiava em diversas direções para o interior (Goya, 1990). A praça surgiu em decorrência do traçado em forma de tabuleiro de xadrez, 
marcada pela presença da igreja matriz, com algumas melhorias das vias públicas, do saneamento e iluminação no seu entorno (Porto Alegre, 2001).

\subsection{Benefícios da vegetação no ambiente urbano}

Embora o meio urbano apresente padrões de qualidade ambiental aquém dos desejáveis para uma vida saudável, aproximadamente metade da população mundial vive em cidades, sendo que, no Brasil, esse valor chega aos $73 \%$ da população (Milano, 1990). A árvore, no conjunto dos fatores ambientais, desempenha várias funções que agem diretamente sobre a saúde física e mental do homem e no metabolismo da cidade (Hoehne, 1944; Mello Filho 1985). Entre os principais benefícios, destacam-se seus valores ecológico, estético, psicológico, econômico e cultural (Sousa \& Bueno, 2000).

\subsubsection{Benefícios ecológicos da arborização urbana}

São considerados benefícios ecológicos (Sanchotene, 1994; Cavalheiro, 1994):

- estabilidade climática, por meio da diminuição da temperatura e do aumento da umidade do ar ;

- melhoria das condições do solo urbano;

- melhoria do ciclo hidrológico;

- redução da poluição atmosférica, por meio da fotossíntese;

- melhoria das condições de conforto acústico e redução da intensidade da luz refletida;

- $\quad$ aumento da diversidade e quantidade da fauna nas cidades.

Uma única árvore não afeta significativamente sua vizinhança em termos climáticos, mas várias árvores distribuídas no local, ou grupo destas, certamente influenciarão no microclima. Para poder cumprir essas funções, formando as chamadas “ilhas de amenização”, a arborização urbana deve ser planejada. (Silva, 2000).

A copa das árvores oferece sombra, barreiras acústica e visual, e proteção térmica, além de fornecer abrigo e alimentação aos poucos animais capazes de adaptação eficaz ao meio urbano, especialmente aves de pequeno porte (Mello Filho, 1985; Kirchner et al., 1990). 


\subsubsection{Benefícios estéticos da arborização urbana}

A maioria das pessoas considera o fator estético como o principal na arborização urbana, em virtude da aparência das árvores ser direta e imediatamente perceptível, por meio da dinâmica imposta pelas árvores, com a alternância de sua aparência em função das estações do ano e de seu estado fenológico (foliação, floração e frutificação); as árvores são importantíssimas para a renovação da paisagem urbana quebrando a monotonia e a frieza típica das construções (Mello Filho, 1985; Detzel, 1990).

Da mesma maneira, a poluição visual pode ser diminuída pelo uso de árvores que, colocadas em situações ideais, atuam obstruindo a visão ou desviando a atenção do observador para outro ponto e transmitindo noções de referência para dimensões e espaços (Detzel, 1990; Cavalheiro, 1994).

\subsubsection{Benefícios psicológicos da arborização urbana}

A existência de bosques, parques, praças e outras áreas verdes possibilita, ainda, recreação e lazer aos habitantes urbanos, especialmente às populações de baixa renda (Detzel,1990; Sanchotene, 1994).

A arborização urbana proporciona à comunidade envolvida oportunidade de maior aproximação, aconchego e relacionamento com seus semelhantes (Biondi et al., 1990; Detzel, 1990). Por sua relação com o exercício do lazer e pelo contato com a vegetação, desempenha um papel positivo em relação ao estado psicológico coletivo da população urbana (Mello Filho, 1982).

A humanização e melhoria do ambiente urbano e a geração de melhores condições de vida e de convivência resultarão das intervenções pelas ações municipais integradas em cada área urbana, adequando-se as características, diversidade e especialização dos elementos componentes do espaço (Busarello, 1990).

Nos ambientes altamente alterados das cidades, a presença de árvores melhora a convivência da população com as estruturas típicas urbanas (Milano et al., 1992b). O reconhecimento dessa importância, em alguns casos, só se dá após esta ter sido suprimida, com a conseqüente eliminação dos benefícios (Detzel, 1992). 


\subsubsection{Benefícios econômicos da arborização urbana}

A presença da vegetação arbórea contribui para a qualificação ambiental e paisagística dos imóveis, valorizando-os economicamente (Sanchotene, 1994).

A importância da arborização para o meio urbano é tanto mais reconhecida quanto maior for a percepção de seus efeitos na melhoria das cidades. Conseqüentemente, a valorização monetária das árvores urbanas será tanto maior quanto mais reconhecida for sua importância (Detzel, 1992). Pode-se também perceber as diferenças existentes entre regiões arborizadas e aquelas desprovidas de vegetação arbórea, quanto ao valor monetário das propriedades (Silva, 2000).

Não se pode esquecer que, quando parques e áreas verdes são estabelecidos de forma adequada, geram empregos diretos e indiretos, contribuem para a manutenção da saúde física e mental do homem e propiciam a geração de divisas, pelo considerável aumento do consumo de bens e serviços (Detzel, 1992).

\subsubsection{Benefícios culturais da arborização urbana}

$\mathrm{O}$ processo de ressaltar os espaços da cidade permite tornar mais clara a estruturação da paisagem urbana para seus habitantes, que terão marcos e referências concretas para participação na gestão do seu habitat (Busarello, 1990).

Temos como alguns exemplos as cidades de Pretória, na África do Sul, e Sevilha, na Espanha, onde as ruas são arborizadas com jacarandá mimoso (Jacaranda mimosaefolia), espécie nativa da América do Sul. Em Belém do Pará, a arborização viária com mangueiras (Mangifera indica) é considerada uma atração turística da cidade, com visita obrigatória, mesmo não sendo estas árvores nativas do Brasil. 


\subsection{Planejamento da arborização urbana}

A arborização das cidades representa a persistência do elemento natural dentro da estrutura urbana, decorrente da realização do processo cultural cujo desenvolvimento é a característica marcante da evolução da espécie humana (Mello Filho, 1985).

Em todas as cidades, vamos encontrar praças ou outras áreas "verdes" ou livres onde a população tem opção de desfrutar suas horas de lazer, mas o rápido aumento populacional, aliado à especulação imobiliária e, principalmente, à falta de planejamento do espaço urbano, têm sido fatores quase sempre determinantes se não na redução das áreas verdes, pelo menos na sua não ampliação. Outro fator de importância refere-se não somente à existência desses espaços verdes na cidade, mas à sua distribuição espacial, que deveria ser feita de maneira a atender a toda a população do município. (Lima et al., 1990).

Arborizar não é somente plantar, mas sim, antes de tudo, estudar detalhadamente todos os pontos básicos que se relacionam com o urbanismo, como também com a espécie ornamental a ser empregada (Serafim, 1951).

Planejar significa dar ordem na evolução de um espaço que possa melhor servir às necessidades futuras; para tanto, é necessário conhecer esse espaço, visando ao atendimento das necessidades urbanas por espaços livres (Goya, 1990). Realizada de forma planejada, a arborização de cidades apresenta-se como uma opção para a melhoria da qualidade ambiental urbana (Detzel, 1992).

Os benefícios do planejamento são obtidos por meio da educação e conscientização ambiental, que levam ao respeito à vegetação urbana (Milano et al., 1992c).

A grande maioria das cidades brasileiras não contou com um planejamento prévio de sua arborização e, conseqüentemente, apresenta sérios problemas de manejo, assim como outras cidades que contaram com planejamento da arborização, porém, pela insuficiência de dados e pesquisas, igualmente apresentaram problemas. É possível considerar três hipóteses de planejamento: o prévio, o planejamento considerando a arborização existente e o replanejamento de ambas as situações anteriores, considerando o dinamismo do meio urbano (Kirchner et al., 1990). 
Planejar, implantar e manter a arborização de uma cidade pressupõe, além de obter melhoria estética e visual do meio urbano, propiciar vários outros benefícios à sua população. Entretanto, assim como os benefícios variam em qualidade e quantidade, em função das características dos espaços arborizados, diferem as potencialidades de espaços arborizáveis de cidade para cidade. (Milano, 1990).

O resultado do planejamento é um sistema de arborização urbana que deve, necessariamente, atender aos objetivos pré-determinados e sofrer um contínuo processo de avaliação e controle. Os acertos e erros advindos desse planejamento devem ser devidamente informados, propiciando, assim, a possibilidade de um replanejamento corretivo e complementar (Kirchner et al., 1990).

Segundo Lapoix (1979), é difícil estabelecer normas para os espaços urbanos sem determinar fundamentos científicos sobre: o desejo expresso dos habitantes segundo níveis sócio-econômicos, sócio-culturais e etários; a densidade de freqüência aceitável para o espaço em função de sua natureza ecológica; a freqüência previsível ou constatada; os custos de implantação, gestão e animação das áreas em questão.

\subsubsection{Escolha do local}

As áreas públicas livres de edificação não se distribuem igualmente pelos diferentes segmentos sociais. Setores ocupados por populações mais carentes são menos favorecidos quanto às áreas livres, tanto em distribuição quanto em tratamento (Goya, 1990). É necessário que se pense com cuidado no ordenamento dos espaços livres dentro do tecido urbano, visando não só à uma otimização do meio físico, mas também à melhoria na oferta de áreas livres para o lazer da população (Cavalheiro \& Del Picchia, 1992).

Os loteamentos clandestinos, em sua maioria, mesmo depois de oficializados, possuem poucas porções de áreas livres. Por essas razões, é recomendado o estabelecimento de uma política de ampliação das áreas livres com a criação de parques, especialmente nos setores de maior carência dessas áreas. (Goya, 1990).

Para a escolha de espaços destinados a novas áreas, Griffith \& Silva (1987) sugeriram espaços já incorporados na cidade. Estes espaços localizam-se dentro da zona 
urbanizada. Muitas dessas áreas foram rejeitadas ou abandonadas por algum motivo, e podem ser utilizadas como alternativas para a criação de áreas verdes públicas, por causa da vantagem de se localizarem dentro da área urbana, onde é mais necessário o espaço verde. $\mathrm{O}$ uso dessas áreas tem como inconveniente o alto custo de aquisição, a freqüente irregularidade na sua configuração e a pequena superfície, em geral, se comparadas às áreas mais periféricas.

Embora possuam características semelhantes, as áreas verdes públicas e privadas devem ser consideradas de forma diferenciada. As primeiras são de responsabilidade da administração pública e visam sobretudo ao atendimento das necessidades como um todo. No segundo caso, estão respaldadas pelo direito de propriedade e, assim, são freqüentes as irregularidades, com proprietários suprimindo áreas importantes ao ambiente e sociedade urbanos. (Kirchner et al., 1990).

Implantar áreas verdes e arborizar cidades são tarefas de caráter altamente técnico e que exigem a integração de órgãos públicos das diferentes esferas governamentais cujas atividades exercidas têm interferência na arborização e no planejamento urbano como um todo (Sanchotene, 1994).

Se é inevitável que parte dos habitantes possua maior contiguidade e usufrua melhor os espaços de uso público, esse privilégio deve restringir-se ao mínimo possível, mediante melhor distribuição e ampliação do Sistema de Áreas Verdes, de modo que o usufrutuário não tenha que despender, andando normalmente, mais do que dez minutos para alcançar o equipamento mais próximo (Lorusso, 1992).

É desejável que cada bairro tenha sua praça com tudo de essencial que uma praça deve oferecer (Demattê, 1997).

\subsubsection{Escolha das espécies}

A escolha das espécies vegetais deve estar baseada em critérios técnicocientíficos, que envolvem a análise das condições ambientais locais e as características fisiológicas e morfológicas das árvores (Milano et al., 1992b).

Para alcançar o desenvolvimento satisfatório e o estado sadio das árvores, é necessário, também, o planejamento prévio de práticas de manutenção, entre as quais 
monitoramento, irrigação, adubação, poda e controle fitossanitário são fundamentais (Milano et al., 1992b).

O plantio de espécies de árvores nativas em ruas, avenidas, parques e praças públicas de nossas cidades é uma prática insignificante, a despeito da riqueza de nossa flora. Isto ocorre exclusivamente por desconhecimento de nossas espécies. Estima-se que aproximadamente $80 \%$ das árvores cultivadas nas ruas das cidades brasileiras são da flora exótica. Evidentemente, nem todas as espécies de árvores da nossa flora prestam-se adequadamente para o plantio em áreas urbanas. A grande maioria, entretanto, pode ser plantada em praças, parques e grandes avenidas. (Lorenzi, 1998).

Toledo Filho \& Parente (1988) observaram a existência de 53 espécies nativas com porte médio e grande, nas praças de algumas cidades da região de Campinas (SP), que podem ser recomendadas para arborização urbana, como forma de proteger e valorizar a flora local. As espécies estudadas pelos autores caracterizam-se pela beleza do conjunto, tronco, folhas e flores, e são recomendadas para a arborização de parques, vias públicas e locais amplos dos centros urbanos. Destas 53 espécies, 10 são recomendadas para arborização urbana no Estado de São Paulo em locais anteriormente revestidos por vegetação de cerrado, caso do Município de Vinhedo. Essas espécies estão relacionadas na Tabela 1, onde estão apresentados dados de porte, hábito de crescimento e informações fenológicas.

Barbosa et al. (2001) comentaram que o Brasil possui $20 \%$ do número de espécies estimadas para todo o Planeta, e que a Mata Atlântica e o Cerrado são ricos em biodiversidade e estão muito ameaçados. Na Tabela 2, são apresentadas espécies arbóreas recomendadas pelos autores, para utilização em áreas urbanas, com ocorrência em Cerrado, apresentando nome científico, porte, deciduidade, desenvolvimento no campo, cor de flor e do fruto.

Toledo Filho \& Parente (1988) e Barbosa et al. (2001) discordaram em alguns parâmetros, o que pode ser justificado pela diferença de local de ocorrência dos exemplares observados, ou seja, em áreas urbanas e em áreas de florestas urbanas. 
Tabela 1. Espécies recomendadas para arborização urbana no Estado de São Paulo em locais anteriormente revestidos por vegetação de cerrado, apresentando espécie; dados de porte (pequeno = P: abaixo de $12 \mathrm{~m}$ de altura; médio $=\mathrm{M}$ : de 12 a $18 \mathrm{~m}$ de altura; grande = G: acima de $18 \mathrm{~m}$ de altura); velocidade de crescimento (rápido: mais que $1 \mathrm{~m}$ em um ano; regular: $1 \mathrm{~m}$ em um ano; lento: menos de $1 \mathrm{~m}$ em um ano); informações fenológicas.

\begin{tabular}{|c|c|c|c|c|c|c|}
\hline \multirow[t]{2}{*}{ Espécie } & \multirow[t]{2}{*}{ Nome popular } & \multirow[t]{2}{*}{ Porte } & \multirow[t]{2}{*}{ Crescimento } & \multicolumn{2}{|c|}{ Floração } & \multirow[t]{2}{*}{ Frutificação } \\
\hline & & & & Cor & Época & \\
\hline Anadenanthera macrocarpa Benth. Brenan & Angico-vermelho & $\mathrm{G}$ & rápido & branco & nov/dez & ago/set \\
\hline Caryocar brasiliensis Camb. & Piqui & $P$ & regular & creme & $\mathrm{jan} / \mathrm{fev}$ & ago/set \\
\hline Copaifera langsdorffii Desf. & Óleo-de-copaíba & $\mathrm{G}$ & lento & branco & jun/jul & ago/set \\
\hline Dipteryx alata Vog. & Cumbaru & M & rápido & creme & fev/mar & out/nov \\
\hline Platymenia reticulata Benth. & Vinhático & $\mathrm{P}$ & regular & branco & $\mathrm{fev} / \mathrm{mar}$ & ago/set \\
\hline Platypodium elegans Vog. & Jacarandá-do-campo & $\mathrm{G}$ & lento & amarelo & set/out & ago/set \\
\hline Pterodon pubescens Benth. & Faveiro & $\mathrm{M}(\mathrm{G})$ & rápido & rosa & out/nov & ago/set \\
\hline Tabebuia ochracea (Cham.) Stand. & Ipê-amarelo & $\mathrm{M}$ & lento & amarelo & ago/set & set/out \\
\hline Terminalia brasiliensis Camb. & Amarelinho & M & lento & verde & ago/set & set/out \\
\hline Vitex montevidensis Cham. & Tarumã & $\mathrm{P}$ & regular & roxa & out/dez & $\mathrm{jan} / \mathrm{fev}$ \\
\hline
\end{tabular}

Fonte: Adaptado de Toledo Filho \& Parente (1988) 
Tabela 2. Espécies arbóreas recomendadas para utilização em áreas urbanas, com ocorrência em Cerrado, apresentando: nome científico; porte (pequeno = P: menos de $5 \mathrm{~m}$ de altura; médio $=\mathrm{M}$ : entre 5 a $10 \mathrm{~m}$ de altura; grande $=\mathrm{G}$ : mais de $10 \mathrm{~m}$ de altura); deciduidade; desenvolvimento no campo (lento: menos de $2 \mathrm{~m}$ em dois anos; moderado: 2 a $3 \mathrm{~m}$ em dois anos; rápido: mais de $3 \mathrm{~m}$ em dois anos); cor da flor e do fruto.

\begin{tabular}{|c|c|c|c|c|c|}
\hline Espécie & Porte & Deciduidade & Desenvolvimento & Cor de flor & Cor do fruto \\
\hline Platypodium elegans Vog. & $\mathrm{M}$ & semidecídua & lento & amarelo/esverdeado & roxo \\
\hline Anadenanthera falcata (Benth) Spreng. & G & decídua & rápido & creme & esverdeado \\
\hline Stryphnodendron adstringens (Mart.) Coville & $\mathrm{P}$ & decídua & lento & esverdeado & marrom \\
\hline Machaerium acutifolium Vog. & G & semidecídua & moderado & branco/vermelho/amarelo & marrom \\
\hline Sclerolobium aureum (Tul.) Benth. & M & decídua & lento & amarelo & esverdeado \\
\hline Dalbergia miscolobium Benth. & M & ermanente/semidecídua & lento & esverdeado/roxo & marrom \\
\hline Lafoensia pacari St. Hil. & $\mathrm{G}$ & decídua & moderado & amarelo/marrom & marrom \\
\hline Ouratea spectabilis (Mart.) Engl. & $\mathrm{P}$ & decídua & lento & amarelo & vermelho \\
\hline Tabebuia ochracea (Cham.) Standl. & M & decídua & moderado & amarelo & esverdeado/marrom \\
\hline Aspidosperma macrocarpon Mart. & G & decídua & lento & branco & marrom \\
\hline Tabebuia caraiba (Mart.) Bur. & G & ermanente/semidecídua & lento & amarelo & esverdeado/marrom \\
\hline Cybistax antisyphilitica (Mart.) Mart. & M & decídua & lento & esverdeado & esverdeado \\
\hline Cordia trichotoma (Vell.) Arab. ex Steud. & $\mathrm{G}$ & decídua & rápido & creme & marrom \\
\hline
\end{tabular}

Fonte: Adaptado de Barbosa et al. (2001) 
Feliciano et al. (1992) avaliaram o desempenho de cinco espécies da Mata Atlântica na arborização de dois bairros distintos da cidade de Recife (PE) e constataram que o principal problema apresentado pelas espécies consistiu em falhas de sobrevivência ocasionadas por depredações ou danos físicos às árvores, variáveis conforme o bairro. No bairro com predominância de população de baixa renda, houve maior grau de depredação que no bairro com população de nível médio.

Segundo Grey \& Deneke (1978), o limite máximo de freqüência para que uma espécie não tenha sua longevidade e sobrevivência ameaçadas parcial ou totalmente pelo ataque de pragas e ou doenças é de 10 a $15 \%$ da composição total.

É comum, na arborização urbana, poucas espécies representarem a maior parte dos indivíduos da população, apesar de este fato não ser desejável, tanto por razões estéticas quanto fitossanitárias (Silva, 2000). Do ponto de vista paisagístico, não são recomendados plantios em blocos heterogêneos, ou seja, aqueles plantados em conjuntos com espécies diversas, porém esse tipo de plantio passa a ser interessante do ponto de vista ecológico, por garantir o alimento à avifauna durante todo o ano (Santiago, 1985).

No trabalho realizado na Universidade Federal de Minas Gerais, no Campus Pampulha, Motta (1998) obteve, como fator de destaque, a diversidade de espécies em sua composição. Foram encontradas mais de 200 espécies, provenientes, em sua maioria, de arborização implantada. A freqüência com que cada espécie contribuiu para a arborização não ultrapassou 6,0\%. O mesmo pode ser notado na cidade de Brasília (DF), onde foram encontradas pelo menos 214 espécies de plantas, sendo 63,55\% de porte arbóreo; nenhuma espécie apresentou ocorrência superior a 7\% (Rodrigues et al., 1994).

Essas situações diferem completamente dos valores encontrados na maioria dos levantamentos efetuados no Brasil. Em Botucatu (SP), a espécie mais plantada, Caesalpinia pelthophoroides, compreende $70,60 \%$ da população de árvores inventariadas na parte central e antiga da cidade (Sousa et al., 1990). Em levantamento realizado em 295 municípios de São Paulo, as espécies de maior ocorrência foram Caesalpinia pelthophoroides, para a qual 53,22\% (157) dos municípios apresentavam freqüência alta, 26,78\% (79) freqüência média e 9,15\% (27) baixa freqüência; Bauhinia variegata e B. variegata var. candida, para a qual 13,22\% (39) dos municípios 
apresentavam freqüência alta, 34,24\% (101) freqüência média e 26,78\% (79) baixa frequiência; Tabebuia spp., para a qual 17,29\% (51) dos municípios apresentavam freqüência alta, 46,78\% (138) freqüência média e 71,87\% (212) baixa freqüência (Winters et al., 1992). Em Vitória (ES), 66,9\% das árvores plantadas na cidade pertenciam a três espécies: Licania tomentosa, Caesalpinia pelthophoroides e Cassia ferruginea (Milano et al., 1992c). Em Manaus, a espécie Licania tomentosa (oitizeiro) predominou com $29,43 \%$ do total, seguida por Terminalia catappa, com 17,87\% (Costa \& Higuchi, 1999). No bairro centro de Santa Maria (RS), as espécies de maior ocorrência, de acordo com Santos \& Teixeira (1990), foram Ligustrum lucidum (20,38\%), Tabebuia chrysotricha (14,64\%) e Lagerstroemia indica (14,59\%). Ainda para Santa Maria (RS), Teixeira et al. (1994) relataram que as espécies de maior ocorrência nas ruas e áreas verdes dos loteamentos da cidade, foram Tipuana tipu $(19,05 \%)$ e Lagerstroemia indica (14,06\%), sendo que as demais espécies ficaram abaixo de $10 \%$ de ocorrência. Em Curitiba, 19\% foram Lagerstroemia indica e 15,4\% foram Ligustrum lucidum (Milano et al., 1992b). Em São Carlos (SP), a espécie de maior ocorrência foi a Michelia champaca (magnólia), com 24,95\%, seguida por Murraya paniculata, com 12,68\% (Rachid, 1999). Michi \& Couto (1996), em trabalho realizado em Piracicaba, afirmaram que 17,9\% das árvores de ruas do município são Caesalpinia pelthophoroides e 17,6\% são Tipuana tipu.

\subsubsection{Plano Diretor de Arborização}

Para o planejamento da ocupação do solo urbano, é fundamental que se realizem pesquisas interdisciplinares envolvendo trabalhos de levantamento da flora e fauna da região, de caracterização do solo em cada setor da área urbana, das necessidades da população da cidade, etc., de forma a oferecerem subsídios que contribuam para a elaboração de projetos que venham a minimizar os efeitos negativos que o crescimento desordenado das áreas urbanas possam causar (Bianchi \& Graziano, 1992).

O planejamento da arborização urbana não deve tratar isoladamente de um programa de arborização de ruas e de um sistema de áreas verdes, mas sim, planejar o todo, inter-relacionando e integrando esses dois componentes. Tal linha de ação 
permitirá sempre tirar proveito das potencialidades próprias de cada cidade para arborização, tanto em termos quantitativos como qualitativos. (Milano, 1990).

Embora quase todas as cidades brasileiras tenham praças, parques e outras áreas verdes, poucas têm esses espaços organizados de modo que não sejam apenas mais uma coleção avulsa de espaços abertos (Griffith \& Silva, 1987).

De acordo com Milano (1990), o plano do sistema de áreas verdes não precisa, necessariamente, obedecer a um plano diretor, mas deve ser orientado por um modelo orgânico que viabilize seu desenvolvimento coerentemente com o crescimento urbano. A melhor maneira de avaliar um sistema de áreas verdes é observar a qualidade de distribuição dessas áreas. Busca-se otimizar e racionalizar a aplicação dos recursos disponíveis, estabelecer crédito dentro e fora da administração pública e conseguir apoio externo.

Considerando tais aspectos, a manutenção e implantação da vegetação na área urbana constitui, hoje, aspecto fundamental da política e administração pública das cidades (Kirchner et al., 1990).

Em decorrência desse fato, Lorusso (1990, p.139) discutiu a necessidade do desenvolvimento de ações a curto prazo, tendo como metas:

$$
\begin{aligned}
& \text { "assegurar através da força legal o máximo possível da } \\
& \text { cobertura vegetal existente; fomentar a arborização pública } \\
& \text { através de novos plantios, obedecendo criteriosamente às } \\
& \text { potencialidades e limitações locais; viabilizar a desapropriação } \\
& \text { de áreas relevantes e/ou significativas para implantação de áreas } \\
& \text { verdes de uso público; implantar e/ou incrementar programas de } \\
& \text { monitoramento e fiscalização; desenvolver programas } \\
& \text { alternativos e/ou de Educação Ambiental”. }
\end{aligned}
$$

A realidade, entretanto, normalmente é outra. Segundo Milano (1990), em geral, quando existem os planos urbanos para as áreas verdes, eles são estáticos, fragmentados e não proporcionam instrumentos capazes de explorar o potencial da árvore, nem como elemento de definição do espaço urbano, nem para a conquista de novos espaços abertos que atendam às demandas da população. 
A fiscalização e o controle da vegetação são realizados por meio da Lei Federal 4771/65, que instituiu o Código Florestal Brasileiro, e o Instituto Brasileiro de Meio Ambiente e Recursos Naturais Renováveis, órgão federal, que tem a competência dessa fiscalização no País. Entretanto, nas cidades de maior porte, delega-se essa função `as prefeituras municipais (Sanchotene, 1994).

Ainda conforme Sanchotene (1994), diversos municípios criaram e aprovaram Planos Diretores de Desenvolvimento Urbano, assim como leis e decretos mais restritivos do que a Lei Federal, dentro de suas realidades locais. Tais instrumentos incluem, em geral, a determinação de padrões de preservação para os diferentes tipos de áreas verdes públicas e particulares, que, em linhas gerais, resumem-se em: árvores localizadas em calçadas, parques, praças e jardins públicos só podem receber tratamento por parte do poder público; árvores localizadas em áreas particulares acabam por receber diferentes tratamentos em cada município.

Relativamente às áreas verdes públicas, Sanchotene (1994) comentou que um dos grandes problemas é a ocupação indevida, seja clandestina, por sub-habitações, ou consensual, por atividades comerciais, associações de bairros, entre outras, e reafirmou a necessidade de uma legislação forte que disponha sobre a proteção das áreas destinadas a praças e parques nos municípios, no que se refere a sua ocupação e tipos de atividades.

O tratamento dispensado à vegetação existente e a projetos novos de arborização em loteamentos deve observar as disposições legais e técnicas do órgão municipal competente e ser elaborado de comum acordo com os demais órgãos direta ou indiretamente envolvidos, para que a vegetação tenha condições de prosperidade e perpetuação, beneficiando efetivamente os seus usuários (Sanchotene, 1994).

Segundo Winters et al. (1992), no levantamento realizado em 295 municípios de São Paulo, foi observado que, em 26,44\% deles, a arborização seguiu um projeto e, em $69,15 \%$, foi aleatória. 


\subsection{Inventário}

A realização de processos de avaliação de áreas verdes contribui notadamente para os objetivos de tornar o ambiente urbano menos artificial e mais humano, propiciando sua ampla gestão por parte do poder público (Lorusso, 1992).

A realização de inventários da arborização urbana é de fundamental importância para garantir a geração dos benefícios proporcionados pela arborização (Takahashi, 1994). Segundo a autora, é uma prática comum em países desenvolvidos, mas no Brasil, teve início apenas na década de 80. A partir de então, iniciou-se uma discussão mais ampla sobre sua real necessidade, os principais métodos, os parâmetros a serem mensurados, os custos, a equipe e os equipamentos necessários para a realização de um inventário.

Segundo Sousa \& Bueno (2000), os inventários já são de domínio público e vêm sendo utilizados em várias cidades brasileiras. Permitem identificar, qualificar e quantificar as espécies existentes na arborização; por isso, são denominados qualitativos e quantitativos. Por meio deles, pode-se conhecer, além das espécies arbóreas existentes, a altura, o diâmetro da copa, a altura da primeira bifurcação, o DAP (diâmetro a altura do peito), as condições fitossanitárias das árvores, e até avaliar as mais adaptáveis e resistentes ao local, as notáveis, de valor histórico ou paisagístico, etc., assim como a freqüência de ocorrência de cada espécie e a quantidade total de árvores.

Os objetivos gerais da realização de um inventário arbóreo podem ser resumidos da seguinte forma: conhecer o patrimônio arbóreo; definir uma política de administração a longo prazo; estabelecer previsões orçamentárias para o futuro; preparar um programa de gerenciamento das árvores; identificar necessidades de manejo; definir prioridades nas intervenções; localizar áreas para o plantio; detectar árvores com necessidades de tratamento ou renovação; utilizar a árvore como vetor de comunicação; funcionar, ainda, como instrumento de persuasão e esclarecimento dos administradores e usuários do local inventariado (Motta, 1998). 


\subsubsection{Tipos de Inventários}

\subsubsection{Total ou parcial}

Um dos primeiros aspectos a serem considerados na definição de um inventário diz respeito a sua abrangência, uma vez que pode ser total para cidades de pequeno e médio porte e parcial para as de grande porte (Motta, 1998).

No inventário total, os dados são coletados em toda a área de levantamento. Já no inventário parcial, opta-se pelo levantamento de certas áreas ou ruas de maior interesse, por meio de um sistema de amostragem de apenas uma parte da população (Motta, 1998).

\subsubsection{Quantitativo, qualitativo ou quali-quantitativo}

Os inventários para avaliação da arborização urbana podem ter caráter quantitativo, qualitativo ou quali-quantitativo. Os dados necessários em cada categoria dependerão dos objetivos, das estratégias e dos procedimentos operacionais dos órgãos responsáveis pela administração desses serviços (Motta, 1998).

A realização de um inventário quantitativo total da arborização de ruas (enumeração completa), além de possibilitar a definição e mapeamento de população de árvores de rua da cidade, permite a identificação da composição real da arborização. Entretanto, considerada a dinâmica normal do processo de arborização, os dados apresentados expressam precisão absoluta apenas até o momento de término da coleta de dados em campo (Milano \& Soares, 1990).

Avaliações periódicas são de extrema importância para determinar as características atuais da arborização, não estando esse tipo de atividade necessariamente relacionado a locais com implantações inadequadas ou sem critérios de manutenção, e sim, a quaisquer locais arborizados. Considerando esta situação, o monitoramento, que resulta de avaliações sistemáticas, pode levar aos seguintes objetivos: programas de poda; identificação de espécies promissoras; controle fitossanitário; determinação de benefícios; necessidades das técnicas de tutoramento (Milano et al., 1992b). 
Essas informações, quando corretamente utilizadas, são instrumentos tanto para o planejamento de novos plantios como para a adequação das práticas de manejo. $\mathrm{O}$ monitoramento sistematizado, por meio dessas avaliações, além de permitir a redefinição dos programas de arborização, possibilita avaliar indiretamente o nível de conscientização e educação ambiental da população em função do estado de conservação e proteção das árvores, assim como a presença e características dos plantios voluntários (Milano et al., 1992a).

Admitindo-se que índices quantitativos, isoladamente, normalmente expressam pouco da realidade da arborização urbana e que caracterizações qualitativas amplas são muitas vezes duvidosas pela dificuldade de obtê-las, somente avaliações e análises combinadas (quali-quantitativas) possibilitam considerações efetivamente úteis. Nesse sentido, é preciso conhecer tanto a quantidade como a distribuição da vegetação no meio urbano, sua situação em termos de propriedade e, se possível, suas características de qualidade (Milano et al., 1992b).

Quando da execução de avaliações da arborização urbana, as áreas verdes de uso público são consideradas as que melhor se prestam a esse fim, por não requererem métodos complicados de avaliação, bastando apenas que se mantenham atualizados os cadastros existentes. Estes devem ser atualizados à medida que surjam novas áreas ou que se procedam a alterações quaisquer naquelas já existentes. Constituem-se em áreas de fácil monitoramento, pois suas características físicas dificilmente são objeto de modificações (Lorusso, 1992).

\section{6 Índice de áreas verdes}

Segundo Nucci (2001), uma questão muito discutida quando se fala em vegetação urbana diz respeito ao índice de áreas verdes. Muitas cidades procuram aumentar seus índices colocando todo espaço não construído como área verde, muitas vezes considerando até a projeção das copas das árvores sobre as calçadas (Cavalheiro \& Nucci, 1998).

Conforme Milano (1990), embora esses índices levem apenas à indicação da ocupação dos espaços urbanos pela vegetação e tenham caráter principalmente 
ambiental, a maioria deles tem caráter social, uma vez que estão ligados a recreação pública e são definidos em relação ao número de habitantes.

Nucci (2001) concordou quando afirmou que, para ser calculado o índice de área verde, devem ser consideradas somente as áreas verdes públicas localizadas na zona urbana e ligadas ao uso direto da população residente na área urbana.

Conforme Nucci \& Cavalheiro (1996) encontram-se na literatura índices que se organizam de acordo com a faixa etária, o tamanho mínimo do espaço, a distância das residências, a área servida, entre outros fatores, sendo que estes índices são sugestões e estão relacionados à realidade de outros países, e não podem ser aplicados diretamente no âmbito nacional. Ainda segundo os autores, esses índices variam de 4 a $10 \mathrm{~m}^{2} /$ habitante para áreas junto às habitações e unidades de vizinhança somando-se, de um modo geral as faixas etárias e as diversas formas de uso.

Cavalheiro \& Del Picchia (1992) discutiram a existência do índice de $12 \mathrm{~m}^{2}$ de área verde/habitante considerado ideal, arraigado e difundido no Brasil e atribuído à ONU, OMS ou FAO. Os autores afirmaram que este índice não é conhecido por aquelas instituições, e supõem que deve se referir somente às categorias de parques de bairro e distritais/setoriais, ou seja, áreas públicas com possibilidades de lazer ao ar livre.

Em 1996, a Sociedade Brasileira de Arborização Urbana (SBAU) propôs como índice mínimo para áreas verdes públicas destinadas a recreação o valor de $15 \mathrm{~m}^{2}$ /habitante (Sociedade Brasileira de Arborização Urbana, 1996).

Como a maioria das cidades brasileiras encontra-se muito aquém do mínimo, Macedo et al. (1997) sugeriram que, além de quantificar áreas verdes em m²/habitante, estas devem ser também classificadas de acordo com a faixa etária, o tamanho mínimo do espaço, distância da residência, etc., de acordo com o modelo de Jantsen (1973), citado por Cavalheiro \& Del Picchia (1992), conforme a Tabela 3.

Segundo Nucci (2001) outros índices devem ser calculados, tais como:

- índice de cobertura vegetal: em que se consideram todas as manchas de vegetação, como, por exemplo, as copas das árvores;

- índice de áreas verdes utilizáveis: quando a área verde não apresenta condições de uso e, após a qualificação das áreas verdes, dever-se-ia recalcular o índice de áreas 
verdes ndicando a quantidade de áreas verdes utilizáveis pela comunidade de acordo com suas qualificações.

Tabela 3. Sugestão de índices urbanísticos para espaços livres.

\begin{tabular}{|c|c|c|c|c|}
\hline CATEGORIAS & $\mathbf{m}^{2} / \mathbf{h a b}^{*}$ & Área mínima & $\begin{array}{l}\text { Distância da } \\
\text { Residência }\end{array}$ & Propriedade \\
\hline \multicolumn{5}{|l|}{ Vizinhança } \\
\hline Até 6 anos & 0,75 & $150 \mathrm{~m}^{2}$ & até $100 \mathrm{~m}$ & público ou particular \\
\hline 6 a 10 anos & 0,75 & $450 \mathrm{~m}^{2}$ & até $500 \mathrm{~m}$ & público ou particular \\
\hline 10 a 17 anos & 0,75 & $5.000 \mathrm{~m}^{2}$ & $1.000 \mathrm{~m}$ & público \\
\hline Parque de bairro & 6,0 & 10ha & $1.000 \mathrm{~m}$ ou $10 \mathrm{~min}$. & público \\
\hline $\begin{array}{c}\text { Parque distrital ou } \\
\text { setorial }\end{array}$ & $6,0-7,0$ & 100ha & $\begin{array}{l}1.200 \mathrm{~m} \text { ou } 30 \mathrm{~min} / \\
\text { veículo }\end{array}$ & público \\
\hline Parque regional & s/ ref.** & $\begin{array}{l}\text { 200ha } \\
\text { área com água }\end{array}$ & $\begin{array}{l}\text { qualquer parte da } \\
\text { cidade }\end{array}$ & público \\
\hline Cemitério & 4,5 & s/ ref.** & s/ ref.** & público ou particular \\
\hline Área para esporte & 5,5 & $\begin{array}{l}\text { 3-5ha } \\
1.500 \mathrm{hab}\end{array}$ & perto das escolas & público ou particular \\
\hline Balneário & $\begin{array}{c}1,0 \\
1 / 10\end{array}$ & $\begin{array}{c}2 \mathrm{ha} \\
0,2 \mathrm{ha}\end{array}$ & perto das escolas & público ou particular \\
\hline Horta comunitária & 12,0 & $300 \mathrm{~m}^{2}$ & s/ ref. $* *$ & público ou particular \\
\hline Verde viário & s/ ref. $* *$ & s/ ref. $* *$ & junto ao sistema viário & público \\
\hline
\end{tabular}

Fonte: Jantzen ${ }^{1}$ citado por Cavalheiro \& Del Picchia (1992).

${ }^{1}$ JANTZEN, F. et al.. Grunflachenbedarf Parkanlagen. Hamburg, Conf.Dir.D.P.J.R.F.A., 1973. 43P. 


\subsection{O Município de Vinhedo}

\subsubsection{Histórico do Município}

A Cidade de Vinhedo tem 53 anos, porém sua história remonta à época do ciclo do ouro, por volta de 1615 e 1620, com as Bandeiras. Surgiram assim diversas Vilas, dentre as quais a de Sant'Anna de Mogi das Três Cruzes, Itu, Jundiaí, entre outras. (Vinhedo, 2002).

Jundiaí era rota obrigatória das Bandeiras que demandavam o interior paulista e, como ocorria com os demais núcleos, possuía seus pequenos "postos avançados", por onde os bandeirantes procuravam, muitas vezes, avançar um pouco mais para o interior. Surgiram, assim, algumas estradas que cortavam a região em direção a São Paulo e Santos, servindo, principalmente, para transporte dos produtos obtidos no sertão ou conduzindo boiadas. (Vinhedo, 2002).

Uma dessas pouquíssimas estradas ficou efetivamente conhecida como a "Estrada da Boiada", onde havia uma casinha ao lado de uma pequena roça, que passou a ser ponto de descanso para os viajantes, antes da chegada a São Paulo (Vinhedo, 2002).

Em 1840, nascia a Vila de Rocinha, que, até então, era denominada Cachoeira, pois fazia parte de uma grande fazenda de café com este nome e que pertencia aos Barões de Arari. Atraente por sua situação geográfica e por sua proximidade a Jundiaí, Rocinha passou a receber novos moradores e foi tomando aspectos de uma vila, onde no centro, foi construída uma pequena capela dedicada a Sant'Anna (Vinhedo, 2002).

Em meados do século XIX, nas décadas finais do escravismo, formou-se, na região, o mais significativo quilombo da Província de São Paulo: o "Quilombo da Rocinha", que, por ser perseguido constantemente, deslocou-se por diversas fazendas da região (Vinhedo, 2002).

No dia 31 de outubro de 1908, o presidente do Estado de São Paulo, M. J. de Albuquerque Lins, promulgou a Lei que "Cria o Distrito de Paz de Rocinha, no município de Jundiahy", sendo iniciada, nesse período a implantação dos serviços urbanos como água, esgoto e iluminação pública (Vinhedo, 2002). 
O Distrito era cortado pela Companhia Paulista de Estradas de Ferro, bastante movimentada para a época, e a partir daí, surgiram os primeiros trechos arruados, e o lugar passou a assumir condições urbanas de um povoado em desenvolvimento. Nunca deixou de ser ponto de passagem no caminho de ligação da Capital do Estado com as cidades do Planalto Paulista, tanto por ferrovia como por rodovia, sendo que, pelo centro da vila, passava a Estrada Velha de São Paulo a Campinas (Vinhedo, 2002).

Além das grandes fazendas de café, a agricultura do Distrito de Rocinha passou a caracterizar-se principalmente pela grande quantidade de videiras predominantes em seus vales e encostas, e em sua decorrência, surgiram indústrias vinícolas caseiras (Vinhedo, 2002).

A pequena vila prosperou agrícola, comercial e industrialmente e, na década de quarenta, surgiram os primeiros movimentos em prol da emancipação políticoadministrativa. Nessa época, foram cotados quatro nomes: Vinhalândia, Videiral, Arariúna, ou Vinhedo, e o Instituto Brasileiro de Geografia e Estatística (IBGE) analisou e escolheu Vinhedo. (Vinhedo, 2002).

No ano de 1948, foi emancipada por meio do Decreto Lei $\mathrm{n}^{\mathrm{o}} 233$ e, em dois de abril de 1949, o novo prefeito e os treze vereadores tomaram posse e incumbiram-se de administrar a nova cidade; por essa razão, esta data foi escolhida para comemorar o aniversário da cidade (Vinhedo, 2002).

A agricultura deixou de ser seu principal ramo da economia e já na década de 20 foi construída a primeira indústria. Hoje, a indústria é responsável por $80 \%$ da arrecadação do município, com mais de 150 empresas instaladas. (Vinhedo, 2002).

A cidade de Vinhedo acolhe uma enorme população de paulistanos que ocupam, com suas casas de veraneio, boa parte dos condomínios existentes na cidade. Nos finais de semana, o número de habitantes chega a aumentar em 15 por cento. (Vinhedo, 2002).

\subsubsection{Praças de Vinhedo}

A primeira praça de que se tem notícia no município é a Praça de Sant'Ana, a qual confunde a sua criação com a fundação da cidade. Os primeiros relatos da sua existência estão ligados à Lei $n^{o}$ 115/53, de 24 de março de 1953, quando passou, de 
Praça da Matriz a ser denominada Praça Olavo Guimarães, sendo que, em 13 de julho de 1964, passou a ter a denominação atual, pela da Lei n ${ }^{\circ} 385 / 64$.

Em 1972, pelo Decreto Municipal n ${ }^{\circ}$ 53/72, passaram a receber as denominações atuais as praças Dom Uldarico Reichel e Padre Luiz Sais. A Praça Comendador Paulo Storani recebeu sua denominação em 24 de outubro de 1977, pelo Decreto Municipal n ${ }^{\circ}$ $139 / 77$.

Sobre a denominação da Praça Corazzari, esta ocorreu em 11 de agosto de 1982 pelo Decreto Municipal no 096/82.

A praça onde se situa o Centro de Convivência passou a denominar-se Praça Nova República em 29 de março de 1985, pelo Decreto Municipal no 041/85.

Em 22 de abril de 1987, duas outras praças, até então sem nome, passaram a ser denominadas Praça Dom Martinho Albert Roth e Praça Prefeito Jair Mendes de Barros, pelo Decreto n ${ }^{\circ}$ 044/87 e Decreto $n^{\circ}$ 046/87 respectivamente.

A Praça da Vitória passou a ser reconhecida por este nome a partir de 11 de agosto de 1987, pelo Decreto ${ }^{\circ}$ 092/87.

A Praça do Aquário foi inaugurada em 1990, sendo um dos pontos mais movimentados do município. Com lago, viveiro e "playground", a praça recebe muitos

visitantes que buscam o lazer e a tranqüilidade. À noite, o local transforma-se em mais um ponto de encontro dos jovens (Vinhedo, 2002). Porém, conforme Lei $\mathrm{n}^{\mathrm{o}}$ 1.701/90, esta praça denomina-se Praça José Mele.

Em 22 de março de 1999, pela Lei Municipal no 2.392, foi dada a denominação ao Centro de Lazer do Trabalhador "Aurora Bueno Sudário".

As outras áreas encontradas durante o levantamento não possuem, atualmente, denominação oficial.

\subsubsection{Legislação ambiental municipal}

O município também é muito jovem, quanto à legislação ambiental. A primeira lei de que se tem notícia é a de $n^{\circ} 1.216 / 84$, datada de 30 de agosto de 1984 e que trata da criação e regulamentação do COMDEMA (Conselho Municipal do Meio Ambiente), órgão consultivo e de assessoramento da Prefeitura Municipal, em questões referentes 
ao equilíbrio ecológico e ao combate à poluição ambiental. Esse Conselho era composto por cinco membros nomeados pelo prefeito.

Em 27 de novembro de 2000, pela lei no 2.538, foi instituída a "Semana do Meio Ambiente" no calendário turístico da cidade, a ser comemorada de 5 a 11 de junho.

Em 12 de abril de 2002, a Prefeitura criou, pela da lei $n^{\circ} 2.634$, que revogou a lei $\mathrm{n}^{\circ}$ 1.216, o CONDEMA (Conselho Municipal de Defesa do Meio Ambiente) e o FMMA (Fundo Municipal do Meio Ambiente).

O Conselho tem por objetivo promover a participação organizada da sociedade civil no processo de discussão e definição da política ambiental em questões referentes à preservação, conservação, defesa, recuperação e melhoria do meio ambiente na cidade, além de propor a instituição do Código Municipal do Meio Ambiente, que deverá contemplar questões relativas à Política de Meio Ambiente e aos Sistemas de Licenciamento e Controle Ambiental Municipal, e incluir os dispositivos de infrações e penalidades em decorrência da fiscalização e autuação dos infratores. É composto por vinte e seis membros de várias entidades e instituições.

São recursos do FMMA: os previstos no orçamento municipal; transferências do Estado e da União; empréstimos nacionais e internacionais; doações vindas de acordos de compensação entre o Ministério Público e infratores ambientais; resultados de aplicações de multas de infração e taxas referentes a licenciamentos ambientais e doações de pessoas físicas ou jurídicas.

Por ser um município jovem, a cidade de Vinhedo ainda está no início no que se refere às legislações pertinentes ao manejo e conservação do ambiente. Para que possam surgir leis adequadas ao perfil da cidade, são necessários inventários como o deste trabalho, visando orientar a população para o incremento e manutenção das áreas existentes e apresentando propostas coerentes dentro do contexto urbano de criação e implantação de novas áreas. 


\section{MATERIAL E MÉTODOS}

\subsection{Caracterização do local}

\subsubsection{Dados físicos}

O município de Vinhedo localiza-se a $23^{\circ} 01^{\prime} 46^{\prime \prime}$ de latitude sul e $46^{\circ} 58^{\prime} 30^{\prime \prime}$ de longitude oeste, tem área de $82 \mathrm{~km}^{2}$ e está situado na região sudeste do Estado de São Paulo, a $76 \mathrm{~km}$ da capital, como mostra a Figura 1. Apresenta topografia de conformação suave, rebaixada, com altitudes variando de 700 a 900m (Vinhedo, 2002).

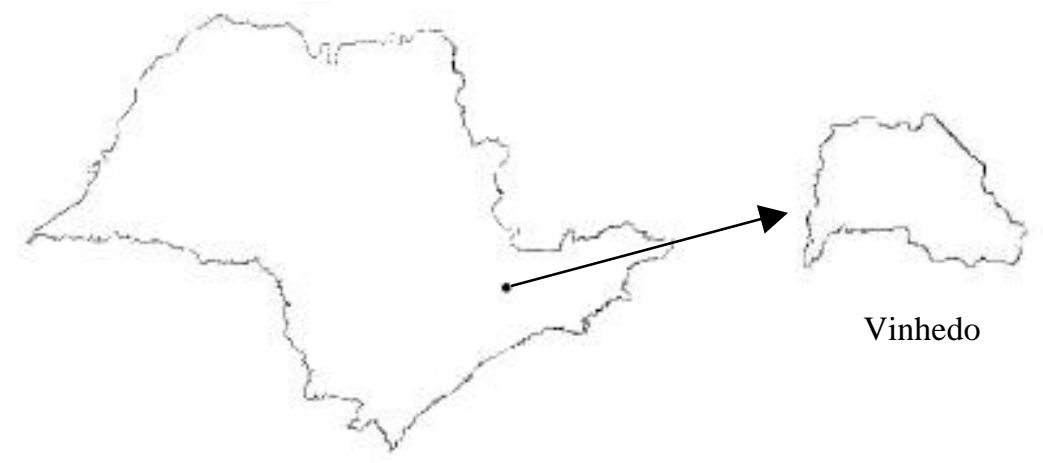

Figura 1 - Localização do município de Vinhedo, no Estado de São Paulo (adaptado de São Paulo, 1993)

O clima, segundo a classificação de Köppen, é Cwa, ou seja, clima subtropical com duas estações definidas, úmida e quente. Apresenta regime pluvial marcado por chuvas de verão e inverno seco. Possui verões cuja temperatura máxima média do mês mais quente é de $28^{\circ} \mathrm{C}$, sendo que, durante o inverno, o mês mais frio apresenta temperatura média inferior a $19^{\circ} \mathrm{C}$. Sua pluviosidade média anual é de $1.404 \mathrm{~mm}$ (Vinhedo, 2002). 


\subsubsection{Dados bióticos}

Os solos da região do município de Vinhedo são do tipo LVA22, ou seja, latossolo vermelho-amarelo, com boa drenagem interna, distrófico, com textura argilosa, além de cambissolos háplicos e distróficos com textura média e argilosa, sendo ambos com horizonte A moderado e proeminente (Oliveira et. al., 1999; Oliveira, 1999).

A vegetação nativa da região é composta basicamente por cerrado, cerradão e capoeira, distribuída conforme mostra a Figura 2. O cerrado é conceituado como vegetação xeromorfa, preferencialmente de clima estacional (mais ou menos seis meses secos), podendo ser encontrada também em clima ombrófilo. O cerradão pertence a um subgrupo do cerrado e apresenta formação típica e característica, restrita a áreas areníticas lixiviadas com solos profundos, ocorrendo em clima tropical eminentemente estacional, e a capoeira é um estádio sucessional que pode ser detectado por sensoriamento remoto em escala de 1:100.000 (Veloso et al., 1991).
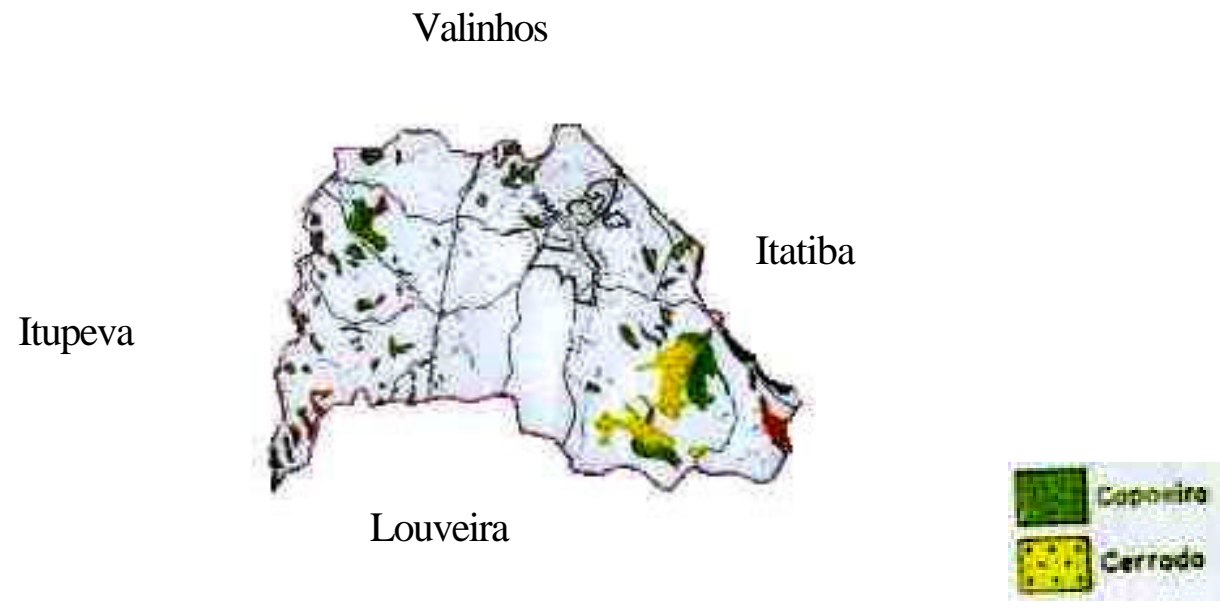

Figura 2 - Mapa da cobertura vegetal natural do Município de Vinhedo (adaptado de São Paulo, 1993) 


\subsubsection{Dados antrópicos}

De acordo com o último censo do IBGE de 2000 (Instituto Brasileiro de Geografia e Estatística, 2002), o município de Vinhedo apresenta população de 47.215 habitantes. Destes, 46.174 residem na área urbana e 1.041 na área rural. Possui também uma população flutuante de aproximadamente 15.000 habitantes. Apresenta densidade demográfica de 522 habitantes por $\mathrm{km}^{2}$.

\subsection{Diagnóstico}

O diagnóstico ambiental foi realizado com a finalidade de se conhecerem os espaços livres existentes e sua distribuição física no município. Foi feito por meio de revisão bibliográfica em literatura específica e da coleta de dados. Esses espaços foram catalogados como praças, de acordo com sua qualidade de uso, podendo ser bons, regulares, ruins e sem qualidade de uso, porém com potencial.

Foi realizado o diagnóstico das espécies arbóreas e da infra-estrutura das praças da cidade de Vinhedo, verificando os equipamentos oferecidos e o estado geral de conservação. Também foi feito um levantamento fotográfico das áreas em estudo, tendo como finalidade retratar as situações descritas. Todas as árvores foram locadas com uso de Sistema Global de Posicionamento (Global Positioning System - GPS), com o intuito de obter a localização mais precisa de cada exemplar arbóreo (Apêndice).

As áreas foram separadas dentro dos bairro em que foram encontradas, considerando-se somente o perímetro urbano.

Esses dados constituíram a essência do trabalho, que visa a analisar a situação dos espaços livres existentes, ao mesmo tempo em que forma uma base de dados para o planejamento ou replanejamento, manejo e monitoramento da arborização local.

\subsection{Coleta de dados}

Os levantamentos foram feitos no perímetro urbano da cidade de Vinhedo, excetuando-se os condomínios, as áreas de parques (Parque da Uva, Represa e Cristo) e as de preservação de manaciais. 
Os dados foram coletados durante os meses de abril e maio de 2002, concomitantemente de praças e árvores, de bairro a bairro. Foram utilizados dois tipos de formulários, sendo um para a caracterização das praças (Anexo A) e outro para a caracterização dos indivíduos arbóreos (Anexo B).

Para a localização das áreas, foi consultada a planta do município de 1997 (Anexo D). Nesse mapa, algumas praças aparecem identificadas e com coloração diferenciada, porém há outras áreas que não estão identificadas como praças, mas possuem a mesma coloração. Todas essas áreas isentas de identificação foram vistoriadas, sendo que foram excluídas as encostas, parques e áreas de preservação de manancial. Além desse tipo de consulta foi, utilizado o conhecimento dos moradores dos bairros para localizar alguns espaços que não estavam demarcados no mapa, mas são utilizados pela população local.

Após a identificação das áreas de estudo, começaram efetivamente os levantamentos, iniciando-se sempre pela definição do bairro e caracterização da praça, seguidas pelo inventário arbóreo.

\subsubsection{Caracterização dos bairros}

A cidade de Vinhedo possui 31 bairros, sendo que apenas oito apresentaram áreas destinadas à praças, totalizando 22 delas.

Para a caracterização dos bairros, foram utilizados dois parâmetros.

O primeiro foi definido pela setorização de áreas feita pela Prefeitura Municipal de Vinhedo, onde são englobados mais que um bairro. Essa setorização se divide da seguinte forma (Anexo D):

S1 - Estritamente Residencial, onde estão localizadas as áreas de condomínios ou de loteamentos de alto padrão, onde não existem áreas de acesso público;

S2 - Residencial, que são áreas próximas ao centro ou localizadas em bairros onde há apenas comércio local;

S3 - Misto, locais onde coexistem residências, comércio e serviços;

S4 - Predominante Industrial, onde existe uma grande concentração de indústrias e apenas residências, em sua maioria, de baixo padrão; 
S5 - Industrial, área estritamente industrial, com apenas algumas moradias, na sua maioria, clandestinas;

S6 - Preservação de Manancial, áreas de manancial, porém onde estão surgindo alguns loteamentos.

O segundo parâmetro foi avaliado por meio da utilização da Planta de Valores Imobiliários para exercício de 2002 que regula a forma de apuração do valor venal dos imóveis para efeito de lançamento dos Impostos Sobre a Propriedade Predial e Territorial Urbana do Município de Vinhedo, editada em 1 de dezembro de 2001 pelo Decreto Municipal no 149.

\subsubsection{Codificação dos bairros e praças}

Para efeito de análise, os Bairros foram codificados com a letra e as praças, com as letras $\mathrm{B}$ e $\mathrm{P}$, em que $\mathrm{B}$ é o bairro onde se localiza a praça e $\mathrm{P}$, a área inventariada. Essa codificação pode ser observada na Tabela 4.

\subsubsection{Inventário da arborização das praças}

Foi realizado o inventário da vegetação arbórea, no qual foram considerados apenas os indivíduos com CAP acima de $10 \mathrm{~cm}$, usando-se de fita métrica. As plantas com CAP inferior àquele valor não foram consideradas, por apresentarem grande risco de morte, principalmente por eventuais depredações.

Foram levantados os seguintes dados: nomes comum e científico das espécies; CAP; altura; aspecto geral; diâmetro de copa nos sentidos norte/sul e leste/oeste; latitude e longitude; existência de flores e frutos; presença de pragas, doenças ou parasitas; ocorrência de podas (drástica e/ou de condução); fitossanidade da raiz, tronco e copa; necessidade de intervenção; presença de epífitas, liquens e briófitas.

Para identificar as espécies, foi coletado material botânico das plantas, que foi comparado com a literatura específica, além de consulta a especialistas. Algumas plantas ainda não foram identificadas por falta de material botânico adequado.

Após a identificação das espécies, estas foram separadas em três grupos, quanto à procedência: 
- nativa: plantas originárias do território brasileiro;

- exótica: plantas não originárias do território brasileiro;

- não identificadas: plantas que não foram identificadas até o momento (Anexo C).

Tabela 4. Codificação e denominação dos bairros e praças existentes na cidade de Vinhedo, 2002.

\begin{tabular}{|c|c|c|c|}
\hline \multicolumn{2}{|r|}{ BAIRRO } & \multicolumn{2}{|r|}{ PRAÇA } \\
\hline Código & Nome & Código & Nome \\
\hline \multirow{6}{*}{ B1 } & \multirow{6}{*}{ João XXIII } & B1P1 & Uderico Reichel \\
\hline & & $\mathrm{B} 1 \mathrm{P} 2$ & Padre Luiz Sais \\
\hline & & B1P3 & sem nome \\
\hline & & B1P4 & Vila João XXIII \\
\hline & & B1P5 & Uderico Reichel \\
\hline & & $\mathrm{B} 2 \mathrm{P} 1$ & Aquário \\
\hline \multirow[t]{2}{*}{ B2 } & \multirow[t]{2}{*}{ Aquário } & $\mathrm{B} 2 \mathrm{P} 2$ & sem nome \\
\hline & & B3P1 & Dom Martinho Albert Roth \\
\hline \multirow[t]{2}{*}{ B3 } & \multirow[t]{2}{*}{ Santa Rosa } & B3P2 & Da Vitória \\
\hline & & B4P1 & Biquinha \\
\hline \multirow[t]{3}{*}{ B4 } & \multirow[t]{3}{*}{ Vila Planalto } & B4P2 & Comendador Paulo Storani, \\
\hline & & B5P1 & De Sant'Ana \\
\hline & & B5P2 & Centro de Convivência \\
\hline \multirow[t]{4}{*}{ B5 } & \multirow[t]{4}{*}{ Centro } & B5P3 & Corazzari \\
\hline & & B5P4 & sem nome \\
\hline & & B5P5 & sem nome \\
\hline & & B6P1 & Prefeito Jair Mendes de Barros \\
\hline \multirow[t]{3}{*}{ B6 } & \multirow[t]{3}{*}{ Jardim Três Irmãos } & B6P2 & sem nome \\
\hline & & B6P3 & sem nome \\
\hline & & B6P4 & sem nome \\
\hline \multirow[t]{2}{*}{ B7 } & \multirow[t]{2}{*}{ Jardim Von Zuben } & B7P1 & sem nome \\
\hline & & & Centro de Lazer do Trabalhador \\
\hline B8 & Capela & B8P1 & "Aurora Sudário" \\
\hline
\end{tabular}


Quanto a conformação geral da árvore, foi analisado e dividido em:

- aspecto normal: quando a maioria das características foi mantida;

- aspecto anormal: quando houve descaracterização do indivíduo por podas mal feitas, drásticas ou ausência de podas de condução.

Quanto à ocorrência de podas, estas foram separadas em dois tipos:

- de limpeza e condução: quando foi realizada a poda para retirada de ramos secos, doentes ou mal formados, sem alterar a estrutura típica da espécie;

- drástica: quando foi realizada a poda para a retirada de ramos grossos, alterando a estrutura da espécie.

Foi medida a altura de ocorrência da primeira ramificação a partir do colo da planta. A literatura específica recomenda que a primeira ramificação ocorra acima de $2 \mathrm{~m}$ do solo, porém, como grande parte das árvores se encontrava fora da área de circulação de pedestres, este dado não apresentou grande relevância.

Foram analisados os aspectos físicos da raiz, tronco e copa divididos em três categorias:

- saudável: isento de sinais de pragas, doenças ou injúrias mecânicas, apresentando forma característica da espécie;

- recuperável: com sinais de pragas, doenças ou injúrias mecânicas, mas que podem ser tratadas;

- irrecuperável: com alto índice de pragas, doenças ou injúrias mecânicas. São plantas que quando apresentam um dos itens (raiz, tronco ou copa) com esta condição deve ser suprimidas.

Para a obtenção da altura, foi utilizada a prancheta dendrométrica. Segundo Batista (s.d.), este instrumento é, talvez, o hipsômetro (instrumento de medição de altura de árvores) mais simples e de maior facilidade de construção. A Figura 3 mostra a sua estrutura, composta basicamente de uma tábua e de um pêndulo. Para determinar a altura total, é feito o somatório das alturas h1 e h2, obtidas por meio de duas visadas, sendo a primeira na base da árvore (h1) e a segunda no topo (h2), a uma distância de 10 metros entre o observador e a árvores. 


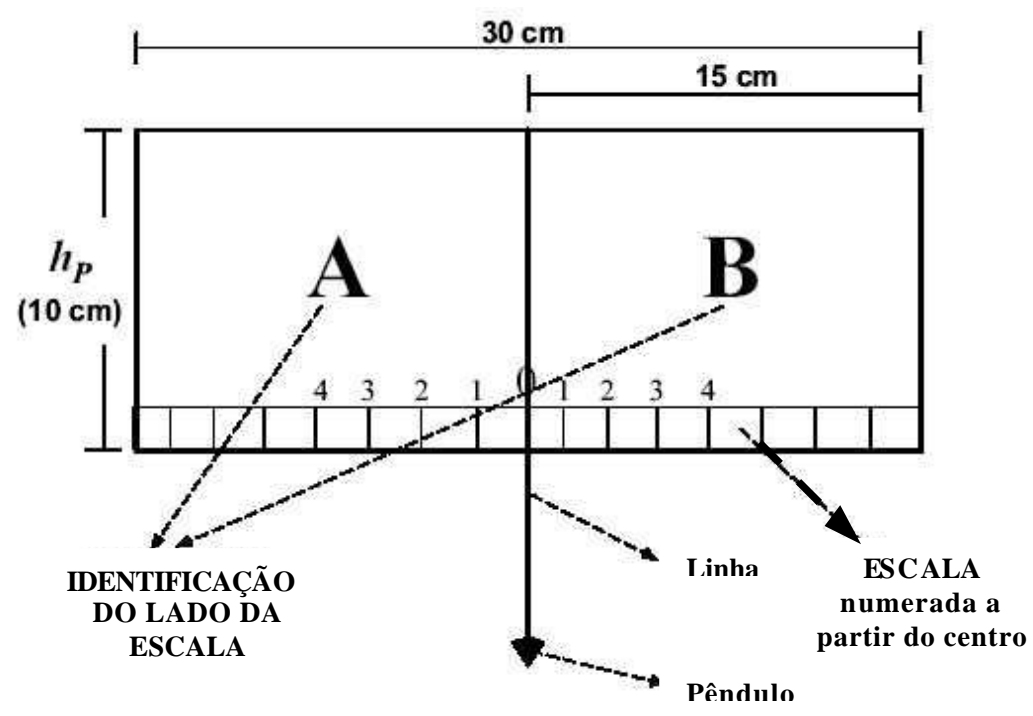

Figura 3 - Estrutura da prancheta dendrométrica (Batista, s.d.)

Para medir o diâmetro de copa, foi utilizada trena de $30 \mathrm{~m}$ e foram consideradas duas medidas, uma no sentido norte/sul e outra no sentido leste/oeste, visando a verificar a uniformidade da copa quanto ao seu desenvolvimento e levantar o índice de cobertura arbórea. As direções foram definidas com uso de bússola existente no GPS.

Foram anotados todos os indivíduos que apresentavam qualquer quantidade de flores e frutos.

Avaliou-se também se havia ocorrência de pragas, doenças ou parasitas.

Para a localização dos indivíduos, foi utilizado o aparelho GPS Etrex Garmin, da Seção de Sementes do Instituto de Botânica de São Paulo.

\subsubsection{Infra-estrutura das praças}

Para os levantamentos, foram considerados os seguintes ítens:

- nome da praça: de acordo com placas existentes no local; em alguns casos, as áreas ainda não foram nomeadas;

- localização: foram anotadas as ruas adjacentes às praças e principalmente o bairro;

- planta baixa: as áreas foram demarcadas na planta geral do município (Anexo D);

- $\quad$ área total de cada praça: foi medidas in loco; 
- número total de exemplares arbóreos, que apresentavam CAP (circunferência de tronco a $1,30 \mathrm{~m}$ do solo) acima de $10 \mathrm{~cm}$;

- elementos arquitetônicos: bancos, "playground", áreas para esportes, espelho d'água, iluminação, pavimentação, sanitários, construções, lixeiras, telefones públicos e outros itens de interesse.

Nas 22 praças, foram ainda analisadas a qualidade da pavimentação, da iluminação e a existência de equipamentos e construções, a saber:

- pavimentação: se possuíam pavimentação, qual o estado de conservação, e se não possuíam pavimentação.

- iluminação: se apresentavam iluminação, qual o estado de conservação, e se não possuíam iluminação.

- existência de equipamentos e construções: verificou-se, também, a existência ou não de equipamentos, como banco, "playground", áreas para esporte, sanitários, pergolados, viveiros de pássaros, coreto e outros.

\subsubsection{Estado de conservação de elementos naturais e construídos}

O estado de conservação dos elementos naturais e construídos também foi aferido visualmente, mediante análise dos seguintes pontos: limpeza, construções, arbustos, canteiros e gramados. Foram classificados em bom, razoável, ruim e inexistente.

\section{a) Gramados:}

- bom: apresentaram-se bem vegetados, com baixa incidência de plantas invasoras, sem falhas, aparados;

- razoável: apresentaram-se com média incidência de plantas invasoras, pequenas falhas, aparados;

- ruim: apresentaram-se com alta incidência de plantas invasoras, grandes falhas, não aparados;

- inexistente: não apresentavam nenhum tipo de cobertura com gramado. 
b) Canteiros:

- bom: com baixa incidência de plantas invasoras, sem falhas, com delimitação de alvenaria;

- razoável: com média incidência de plantas invasoras, com pequenas falhas, com delimitação de alvenaria;

- ruim: com alta incidência de plantas invasoras, com grandes falhas, sem delimitação;

- inexistente: não apresentavam nenhum tipo de cobertura vegetal.

c) Arbustos:

- bom: com podas de condução e limpeza, sem pragas e doenças;

- razoável: com podas de condução e limpeza, com pequena incidência de pragas e doenças;

- ruim: sem podas de condução e limpeza, com alta incidência de pragas e doenças;

- inexistente: não apresentavam nenhum tipo de vegetação arbustiva.

d) Construções (banheiros, pergolados, viveiros de pássaros, coreto, etc.):

- bom: com pintura em bom estado, sem remendos, sem rachaduras;

- razoável: com pintura com pequenas manchas, sem remendos, sem rachaduras;

- ruim: sem pintura, com remendos, com rachaduras;

- inexistente: não apresentavam nenhum tipo de construção.

e) Limpeza:

- bom: sem lixo no passeio, no gramado ou nos canteiros;

- razoável: com pequena quantidade de lixo no passeio, no gramado ou nos canteiros;

- ruim: com grande quantidade de lixo no passeio, no gramado ou nos canteiros;

- $\quad$ inexistente: não apresentavam nenhum tipo de limpeza.

Foram analisadas também as áreas incompletas, que são aquelas que se apresentaram sem arborização, arbustos ou mesmo canteiros, o que ocasionava desequilíbrio paisagístico. 


\subsubsection{Estado de consolidação da vegetação arbórea}

A análise deste item foi feito por meio da seguinte classificação da vegetação arbórea:

- áreas não consolidadas: apresentam altura média das árvores inferior a 2,0m e CAP médio até $10 \mathrm{~cm}$; estão incluídas as áreas que não possuem vegetação arbórea;

- áreas em consolidação: apresentam árvores com altura média entre 2,1 e 6,0m e CAP médio de 11 a 50cm;

- áreas consolidadas: apresentam árvores com altura média superior a 6,1m e CAP médio acima de $50 \mathrm{~cm}$.

As áreas foram demarcadas, com cores diferentes, em planta baixa (Anexo D), segundo a seguinte classificação:

- verde: para áreas consolidadas;

- amarelo: para áreas em consolidação;

- vermelho: para áreas não consolidadas.

\subsubsection{Outros aspectos observados}

Foram anotados outros aspectos relevantes que não se incluíram nos anteriores, tais como:

a) Faixa etária dos freqüentadores:

- crianças e adolescentes: entre 0 e 17 anos;

- adultos: entre 18 e 50 anos

- idosos: acima de 50 anos.

\section{b) Volume de utilização:}

- baixo: estão disponíveis mais de 50\% de bancos, "playground" e áreas para esporte;

- médio: com 30\% a 50\% dos bancos, "playground" e áreas para esporte disponíveis;

- alto: com menos de 30\% dos bancos, "playground" e áreas para esporte disponíveis.

\section{c) Forma de usos:}

- lazer passivo: quando a população apenas contempla a paisagem, pratica leitura ou jogos de carta e dominó; 
- lazer ativo: quando são praticados esportes; jogos com bola e utilização de "playground".

\section{d) Procedência da população:}

- próxima: se os utilitários residem em locais próximos às áreas (distância mais de 10 minutos de caminhada);

- distante: quando os usuários têm que se deslocar utilizando algum meio de transporte.

e) Acesso:

- fácil: com ponto de ônibus nas proximidades e fácil estacionamento para veículos;

- difícil: sem ponto de ônibus nas proximidades e de difícil estacionamento para veículos.

\section{f) Comércio:}

- local: se existem lojas ladeando a praça;

- ambulante: se existem barracas distribuídas no perímetro da praça.

\subsubsection{Classificação das praças em categorias}

Para a classificação das praças em categorias, foi utilizada a sugestão de índices urbanísticos para espaços lvres, conforme o modelo de Jantzen citado por Cavalheiro \& Del Picchia (1992).

Para a classificação das áreas, foi levado em consideração apenas o tamanho das praças e não foram calculados os índices de área por habitante, por não terem sido encontrados dados sobre as populações de cada bairro. 


\subsection{7 Índices calculados}

\subsubsection{1 Índice de áreas verdes (IAV)}

\subsubsection{1 Índice de áreas verdes total (IAVT)}

Para calcular o índice de áreas verdes da cidade de Vinhedo, foi considerado o somatório das áreas totais das praças, expresso em metro quadrado, dividido pelo número de habitantes da área urbana.

$$
\text { IAVT }=\frac{\sum \text { das áreas totais das praças }}{\mathrm{N}^{\mathrm{o}} \text { de habitantes da área urbana }}
$$

\subsubsection{2 Índice de áreas verdes para parque de vizinhança (IAVPV)}

$$
\mathrm{IAVPV}=\frac{\Sigma \text { das áreas de parque de vizinhança }}{\mathrm{N}^{\mathrm{o}} \text { de habitantes da área urbana }}
$$

\subsubsection{3 Índice de áreas verdes para parque de bairro (IAVPB)}

$$
\text { IAVPB }=\frac{\sum \text { das áreas de parque de bairro }}{\mathrm{N}^{\mathrm{o}} \text { de habitantes da área urbana }}
$$

\subsubsection{2 Índice de cobertura vegetal (ICV)}

Para obtenção do ICV, foi utilizado o somatório áreas de copa, expresso em $\mathrm{m}^{2}$, dividido pelo número total de habitantes da área urbana.

$$
\mathrm{ICV}=\frac{\Sigma \text { das áreas de copa }}{\mathrm{N}^{\mathrm{o}} \text { de habitantes da área urbana }}
$$

As áreas dos canteiros sem arborização não foram consideradas. 


\subsubsection{3 Índice de áreas verdes utilizáveis (IAVU)}

O cálculo do índice de áreas verdes utilizáveis foi obtido por meio da seguinte fórmula:

$$
\mathrm{IAVU}=\frac{\sum \text { das áreas }\left(\mathrm{m}^{2}\right) \text { da praças totalmente utilizáveis }}{\mathrm{N}^{\mathrm{o}} \text { de habitantes da área urbana }}
$$

As praças foram classificadas em totalmente utilizáveis, parcialmente utilizáveis e sem condições de uso:

- totalmente utilizáveis: com presença de bancos, gramados, canteiros, arbustos, limpeza e construções em bom estado de conservação;

- parcialmente utilizáveis: com presença de bancos; gramados, canteiros, arbustos, limpeza e construções em estado razoável de conservação;

- sem condições de uso: sem presença de bancos; gramados, canteiros, arbustos, limpeza e construções em estado ruim de conservação;

\subsubsection{4 Índice de área verde por bairro (AVB)}

$\mathrm{O}$ cálculo da porcentagem de área verde por bairro foi obtido pela seguinte fórmula:

$$
\mathrm{IAVB}=\frac{\sum \text { das áreas }\left(\mathrm{m}^{2}\right) \text { da praças de cada bairro }}{\text { Área total do bairro }}
$$




\section{RESULTADOS E DISCUSSÃO}

\subsection{Situação geral}

A cidade de Vinhedo (SP) possui 31 bairros, sendo que apenas oito apresentam áreas destinadas a praças, totalizando 22 destas. A data de implantação da cobertura vegetal dessas praças, não está documentada, mas tão somente a sua data de denominação mediante decretos da Câmara Municipal, o que não se permite precisar as datas de plantio das espécies vegetais ou de introdução de elementos construídos.

\subsubsection{Situação das praças}

\subsubsection{Descrição das praças analisadas}

\subsection{Praça B1P1 (Uderico Reichel)}

Localizada no bairro João XXIII, possui $450 \mathrm{~m}^{2}$, com 11 exemplares arbóreos apresentando altura média de 11,94m e CAP médio de 1,50m indicando a presença de indivíduos adultos. Existem oito bancos de alvenaria, e a praça apresenta boa iluminação e pavimentação. Não possui canteiros ou arbustos, e o gramado e a limpeza geral encontram-se em bom estado. É freqüentada apenas pela população do entorno, composta principalmente por idosos e crianças 0 a 6 anos que utilizam a área para lazer passivo. Seu volume de utilização é médio, possui apenas comércio local e seu acesso é fácil (Figura 4). 


\subsection{Praça B1P2 (Padre Luiz Sais)}

Esta praça também se encontra no bairro João XXIII e possui $400 \mathrm{~m}^{2}$. São oito exemplares arbóreos com altura média de 12,01m e CAP médio de 1,45m, distribuídos em toda a área restritos aos canteiros, que são bem delimitados. É uma área com vegetação consolidada. Possui 15 bancos de alvenaria, apresenta boa iluminação e pavimentação. Seu estado de conservação é bom. Possui algumas mesas de alvenaria, muito utilizadas para jogos de carta ou dominó e que estão bem conservadas. É freqüentada apenas pela população próxima, composta pelas mais diversas faixas etárias, com alto grau de utilização e, nos finais de semana, apresenta algum comércio ambulante. A manutenção é feita pelos próprios moradores, tendo grande importância para os habitantes locais. É de fácil acesso (Figura 4).

\subsection{Praça B1P3 (sem nome)}

Está localizada no bairro João XXIII, possui $750 \mathrm{~m}^{2}$ e 13 exemplares arbóreos com altura média de 13,24m e CAP médio de 1,35m, apresentando vegetação consolidada. Possui 13 bancos de alvenaria e "playground". Apresenta boa iluminação, porém não há pavimentação. Encontra-se em estado razoável de conservação. É intensamente freqüentada, principalmente de crianças de 6 a 10 anos, para recreação. $\mathrm{O}$ fato de não haver nenhum tipo de revestimento causa dificuldade de uso nas estações chuvosas. É de fácil acesso e não possui nenhum tipo de comércio (Figura 4).

\subsection{Praça B1P4 (Vila João XXIII )}

Localiza-se no bairro João XXIII. Com $1.000 \mathrm{~m}^{2}$ e um total de 33 exemplares arbóreos com altura média de $6,80 \mathrm{~m}$ e CAP médio de $0,65 \mathrm{~m}$ em sua grande maioria plantados pela própria população. Esses plantios, futuramente, causarão um adensamento inadequado, pois não foram observados os espaçamentos mínimos para o desenvolvimento dessas plantas, além de estar ocorrendo sombreamento denso. Possui 24 bancos de alvenaria e apresenta iluminação razoável e boa pavimentação. Encontrase em bom estado de conservação. É freqüentada principalmente pela população idosa das proximidades com finalidade de contemplação e descanso. Essas pessoas também 
são responsáveis pela manutenção da área. É uma área de grande importância aos moradores locais, sendo seu acesso fácil e possuindo comércio local. Seu volume de utilização é alto, principalmente nos finais de semana (Figura 4).

\subsection{Praça B1P5 (Uderico Reichel)}

Localizada no bairro João XXIII, provavelmente é proveniente de um desmembramento da praça B1P1, com o surgimento de ruas adjacentes. Possui $400 \mathrm{~m}^{2}$ e sete exemplares arbóreos com altura média de 8,83m e CAP médio de 1,20m, mostrando que também se trata de uma área com vegetação consolidada. Possui cinco bancos de alvenaria, situação precária de iluminação, pavimentação e conservação. Não possui canteiros ou arbustos, e o gramado encontra-se em estado ruim. É muito freqüentada para recreação, principalmente crianças de 6 a 10 anos, provenientes de residências próximas à praça. Seu volume de utilização é médio. $\mathrm{O}$ fato de não haver nenhum tipo de revestimento causa dificuldade de uso nas estações chuvosas. Apresenta fácil acesso (Figura 4).

\subsection{Praça B2P1 (Aquário)}

Esta praça localiza-se no bairro Aquário, possui $32.000 \mathrm{~m}^{2}$ e 181 exemplares arbóreos, com altura média de 6,80m e CAP médio de $0,70 \mathrm{~m}$, sendo que grande parte é composta por palmeiras. Possui 157 bancos de alvenaria; "playground" cercado, todo revestido de areia, com banheiro infantil, horário pré-determinado de funcionamento e restrição de idade; espelho d'água abastecido por uma nascente existente na própria área, ocupando aproximadamente um terço da área total, permitindo sua travessia através do estreitamento do leito, cruzado por pontes de madeira; viveiros para aves; pergolado com plantas escandentes; pista de "cooper"; bebedouros e banheiros são outros equipamentos existentes na área. É freqüentada por grande volume de pessoas das mais diversas faixas etárias, advindas de vários pontos da cidade, principalmente nos finais de semana, para lazer ativo e passivo, além de utilizarem os bares adjacentes. Apresenta algum comércio ambulante, principalmente nos finais de semana. Recentemente, foram instaladas câmeras de circuito fechado de televisão com o intuito de inibir eventuais 
roubos e delitos como vandalismo. Apresenta lixeiras distribuídas ao longo de toda a praça. Sua situação de iluminação, pavimentação e conservação é boa e seu acesso é fácil (Figuras 4 e 5).

\subsection{Praça B2P2 (sem nome)}

Também se localiza no bairro Aquário, possui $800 \mathrm{~m}^{2}$ e 15 exemplares arbóreos com altura média de 8,42m e CAP médio de 0,83m, indicando que a área tem arborização consolidada. Situa-se ao lado da praça Aquário, o que, provavelmente, explica seu baixo volume de utilização. Grande parte da área é sombreada, possui 25 bancos de alvenaria e um coreto, onde são realizadas aulas de catecismo nos finais de semana. Apresenta boa situação em termos de iluminação, pavimentação e conservação. Possui lixeiras de alvenaria distribuídas ao longo da praça e é fácil (Figura 5).

\subsection{Praça B3P1 (Dom Martinho Albert Roth)}

Está localizada no bairro Santa Rosa, possui $2.700 \mathrm{~m}^{2}$ e 34 exemplares arbóreos com altura média de $8,31 \mathrm{~m}$ e CAP médio de 0,83m, indicando que a área temarborização consolidada. Possui três bancos de alvenaria e apresenta iluminação precária, com apenas um poste; não há nenhum tipo de pavimentação. $O$ terreno apresenta desníveis acentuados e foi observada grande quantidade de lixo e entulho. O seu estado de conservação, tanto em relação aos gramados quanto de limpeza é ruim. Não tem canteiros, arbustos ou construções. Não é utilizada pela população, apesar do acesso ser fácil. Fica em frente ao cemitério e ao lado do velório municipal. Está necessitando de intervenção urgente (Figura 5).

\subsection{Praça B3P2 (da Vitória)}

Localiza-se também no bairro Santa Rosa, possui $242 \mathrm{~m}^{2}$ e 16 exemplares arbóreos com altura média de $8,31 \mathrm{~m}$ e CAP médio de $0,83 \mathrm{~m}$, indicando que a área tem arborização consolidada, porém, do total de espécies, 10 são palmeiras. Apresenta sombreamento denso. Existem dois bancos de alvenaria. Os canteiros estão em situação precária e os arbustos estão em boas condições. Apresenta situação razoável de 
conservação, com boa pavimentação, embora sua iluminação seja precária. A área é utilizada para depósito de material de uma pequena empresa de jardinagem, que possui seu acesso exclusivo pela praça. Apesar de seu acesso ser fácil, apresenta volume baixo de utilização e, mesmo assim, somente é utilizada como ponto de descanso para pedestres (Figura 5).

\subsection{Praça B4P1 (da Biquinha)}

Localizada na Vila Planalto, possui $594 \mathrm{~m}^{2}$ e 12 exemplares arbóreos com altura média de 9,73m e CAP médio de 0,78m (indicando arborização consolidada) cinco bancos de alvenaria e uma bica, que se encontra desativada e canalizada. Apresenta boa pavimentação e razoável estado de conservação e iluminação. Durante o levantamento, a praça estava passando por remodelamento. Fica próxima à praça Comendador Paulo Storani (B4P2), mas não é utilizada pela população, apesar do fácil acesso (Figura 5).

\subsection{Praça B4P2 (Comendador Paulo Storani)}

Também está situada na Vila Planalto, possui $4.000 \mathrm{~m}^{2}$ e 33 exemplares arbóreos, bem distribuídos, com altura média de 6,52m e CAP médio de 0,80m, indicando que a área tem arborização consolidada. A proporção entre sol e sombra está bem equilibrada.

Apresenta sete bancos de alvenaria e "playground" revestido de areia. É freqüentada principalmente por crianças de 0 a 6 anos, para recreação. Aproximadamente dois terços da área são permeáveis. Apresenta bom estado de conservação, pavimentação e iluminação. É uma das únicas áreas que possui acesso para deficientes físicos, porém este se encontra em estado precário. Seu acesso é fácil (Figura 5).

\subsection{Praça B5P1 (Sant'Ana)}

Localizada no Centro, é a praça mais antiga da cidade, sendo ladeada quase que totalmente por comércio. Possui $2.250 \mathrm{~m}^{2}$ e 62 exemplares arbóreos, distribuídos em canteiros delimitados, com altura média de 7,32m e CAP médio de 0,92m, indicando que a área tem arborização consolidada. A proporção entre sol e sombra está bem equilibrada. Existem 10 bancos de madeira, banheiros, caixa de correio, bebedouro e 
lixeiras. A maior parte do piso é impermeável. É utilizada pela população como ligação entre as ruas Nove de Julho (principal do comércio) e Humberto Pescarini (onde se encontra a Prefeitura) e por pequenos grupos de idosos para lazer e descanso. Abriga comércio ambulante nos finais de semana e é muito utilizada para feiras de artesanato. Existe um pequeno quiosque que comercializa artesanato diariamente, sendo a verba revertida para instituições de caridade. Apresenta bom estado de conservação, iluminação e pavimentação (Figura 6).

\subsection{Praça B5P2 (Centro de Convivência)}

Localizada no Centro, possui $10.000 \mathrm{~m}^{2}$ e 240 exemplares arbóreos com altura média de $8,73 \mathrm{~m}$ e CAP médio de $0,72 \mathrm{~m}$, indicando que a área tem arborização consolidada, distribuída em canteiros bem delimitados, sendo que boa parte da sua área apresenta alto grau de inclinação. Existem sete bancos de ferro e madeira, um telefone público, concha acústica e lixeiras. Possui também um pequeno "playground". Nessa área, ficam localizados o Banco do Povo, o Posto de Atendimento ao Trabalhador e a Secretaria Municipal de Habitação. É mais movimentada durante a semana como passagem ou para consultas aos órgãos ali existentes. É muito utilizada para eventos especiais por várias faixas etárias de público. O acesso é fácil, possuindo área de estacionamento. Apresenta boa iluminação e pavimentação. Encontra-se em bom estado de conservação. Estão ocorrendo pequenas invasões em áreas limítrofes (Figura 6).

\subsection{Praça B5P3 (Corazzari)}

Localizada no Centro, possui $700 \mathrm{~m}^{2}$ e 20 exemplares arbóreos com altura média de 5,65m e CAP médio de $0,66 \mathrm{~m}$, indicando que a área tem arborização jovem e está distribuída em pequenos maciços. Existem três bancos de alvenaria. Apresenta boa iluminação, pavimentação e encontra-se em bom estado de conservação. Apenas a limpeza está em situação razoável. Apesar do acesso fácil, é pouco utilizada pela população, sendo usada apenas como ponto de descanso para pedestres (Figura 6). 


\subsection{Praça B5P4 (sem nome)}

Também localizada no Centro, possui $4.000 \mathrm{~m}^{2}$ e 13 exemplares arbóreos com altura média de $8,01 \mathrm{~m}$ e CAP médio de $0,79 \mathrm{~m}$, indicando que a área tem arborização adulta consolidada, distribuída em canteiros delimitados. Existem 10 bancos de madeira e telefone público. Possuía um pequeno quiosque de lanches, que foi removido. É de difícil acesso, levando-se em consideração que está localizada entre as movimentadas ruas Manoel Mateus e Anésio A. do Amaral. Apresenta boa iluminação e pavimentação. Encontra-se em bom estado de conservação. É freqüentada por uma população de idosos que utiliza a área para contemplação e descanso (Figura 6).

\subsection{Praça B5P5 (sem nome)}

Localizada no Centro, ao lado da Santa Casa; atualmente está sendo utilizada como estacionamento. Seu acesso é fácil, porém não possui nenhum tipo de infraestrutura e sua vegetação é do ípo rasteiro. Possui $6.000 \mathrm{~m}^{2}$ e necessita de intervenção urgente (Figura 6).

\subsection{Praça B6P1 (Prefeito Jair Mendes de Barro)}

Localizada no bairro Jardim Três Irmãos, possui $1.700 \mathrm{~m}^{2}$ e 24 exemplares arbóreos com altura média de 5,41m e CAP médio de 0,49m, indicando que a área tem arborização jovem, distribuída em canteiros delimitados. Existem 11 bancos de alvenaria, "playground", palco, ponto de ônibus e um pergolado de madeira. Apresenta boa iluminação e pavimentação. Apresenta gramados e canteiros em razoável estado de conservação e limpeza razoável. De fácil acesso, é freqüentada por uma população composta de todas as faixas etárias advindas do entorno (Figura 7).

\subsection{Praça B6P2 (sem nome)}

Localiza-se no Bairro Jardim Três Irmãos, possui $540 \mathrm{~m}^{2}$ e oito exemplares arbóreos com altura média de 4,35m e CAP médio de 0,34m, indicando que a área tem arborização jovem, distribuída em todo o gramado. Seu piso é todo revestido de grama, não apresentando nenhum tipo de calçamento. Apresenta uma situação razoável de 
conservação de canteiros, gramados, arbustos e limpeza, sem iluminação ou pavimentação. É de fácil acesso porém não é utilizada pela população (Figura 7).

\subsection{Praça B6P3 (sem nome)}

Também está localizada no bairro Jardim Três Irmãos e possui $1.600 \mathrm{~m}^{2}$ com mudas novas de CAP menor que $10 \mathrm{~cm}$. Apresenta uma situação boa de gramados e limpeza em bom estado, porém, sem iluminação ou pavimentação. Apesar de ser de fácil acesso, não é utilizada pela população (Figura 7).

\subsection{Praça B6P4 (sem nome)}

Localizada no bairro Jardim Três Irmãos, possui $530 \mathrm{~m}^{2}$, com mudas novas de CAP menor que $10 \mathrm{~cm}$. Apresenta uma situação razoável de limpeza; estado de conservação de gramados e canteiros considerado ruim; não possui iluminação. Embora seja de fácil acesso, não é utilizada pela população (Figura 7).

\subsection{Praça B7P1 (sem nome)}

Localizada no bairro Von Zuben, possui $1.250 \mathrm{~m}^{2}$ com apenas três exemplares arbóreos com altura média de 2,50 m e CAP médio de $0,13 \mathrm{~m}$, indicando que a área tem arborização jovem, sendo restrita a apenas um ponto da praça. Possui "playground" e fácil acesso, porém é pouco utilizada pela população. Apresenta bom estado de conservação e pavimentação. Apresenta relevo acidentado, sendo que a praça é dividida por uma escada de madeira que se encontra em bom estado de conservação. Não possui iluminação. É recomendável que sejam efetuados novos plantios para a melhoria da relação entre sol e sombra da área (Figura 7). 

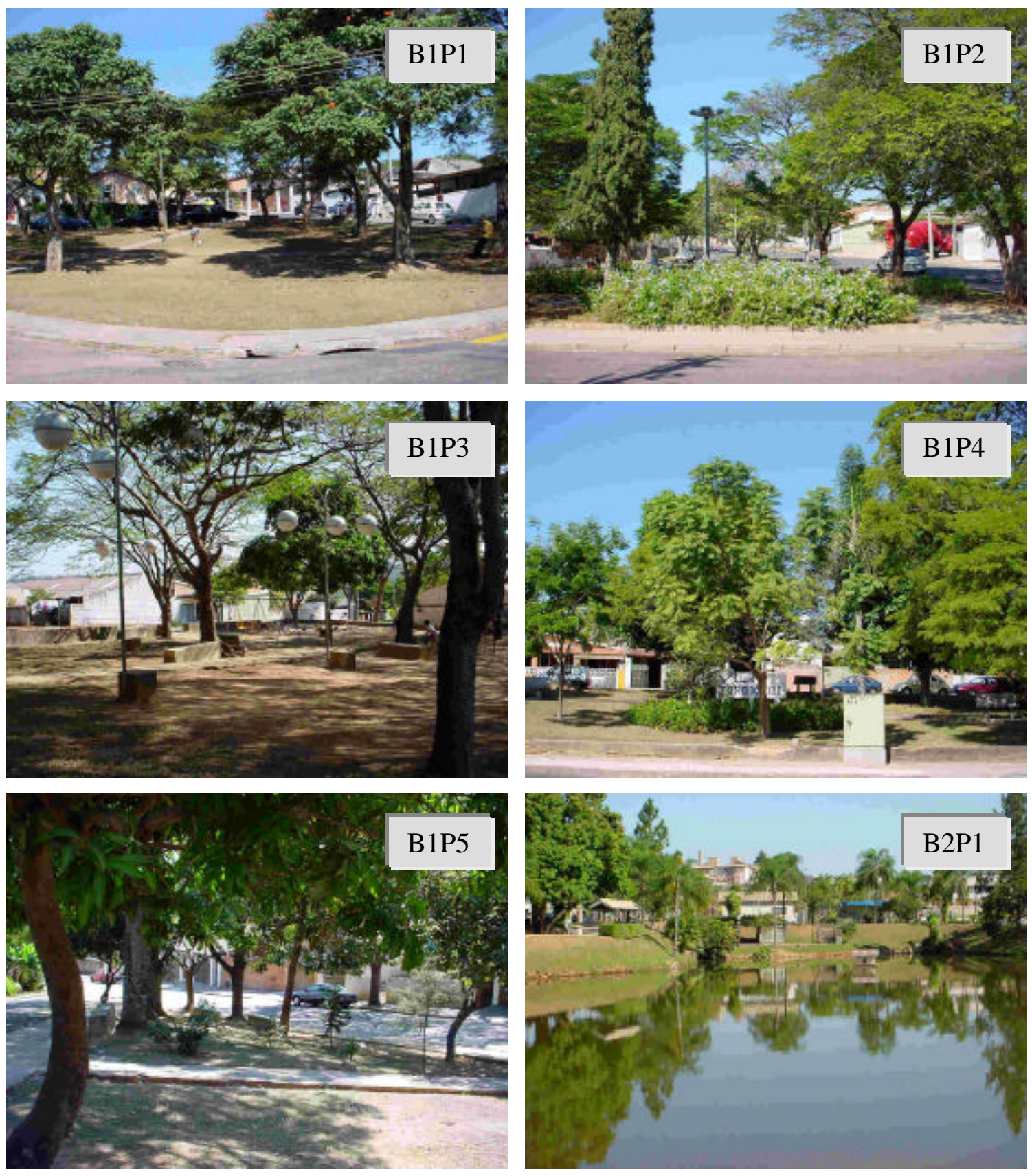

Figura 4 - Aspecto geral das praças B1P1 (Uderico Reichel), B1P2 (Padre Luiz Sais), B1P3 (sem nome), B1P4 (Vila João XXIII), B1P5 (Uderico Reichel) e B2P1 (Aquário) da cidade de Vinhedo (SP), 2002. 

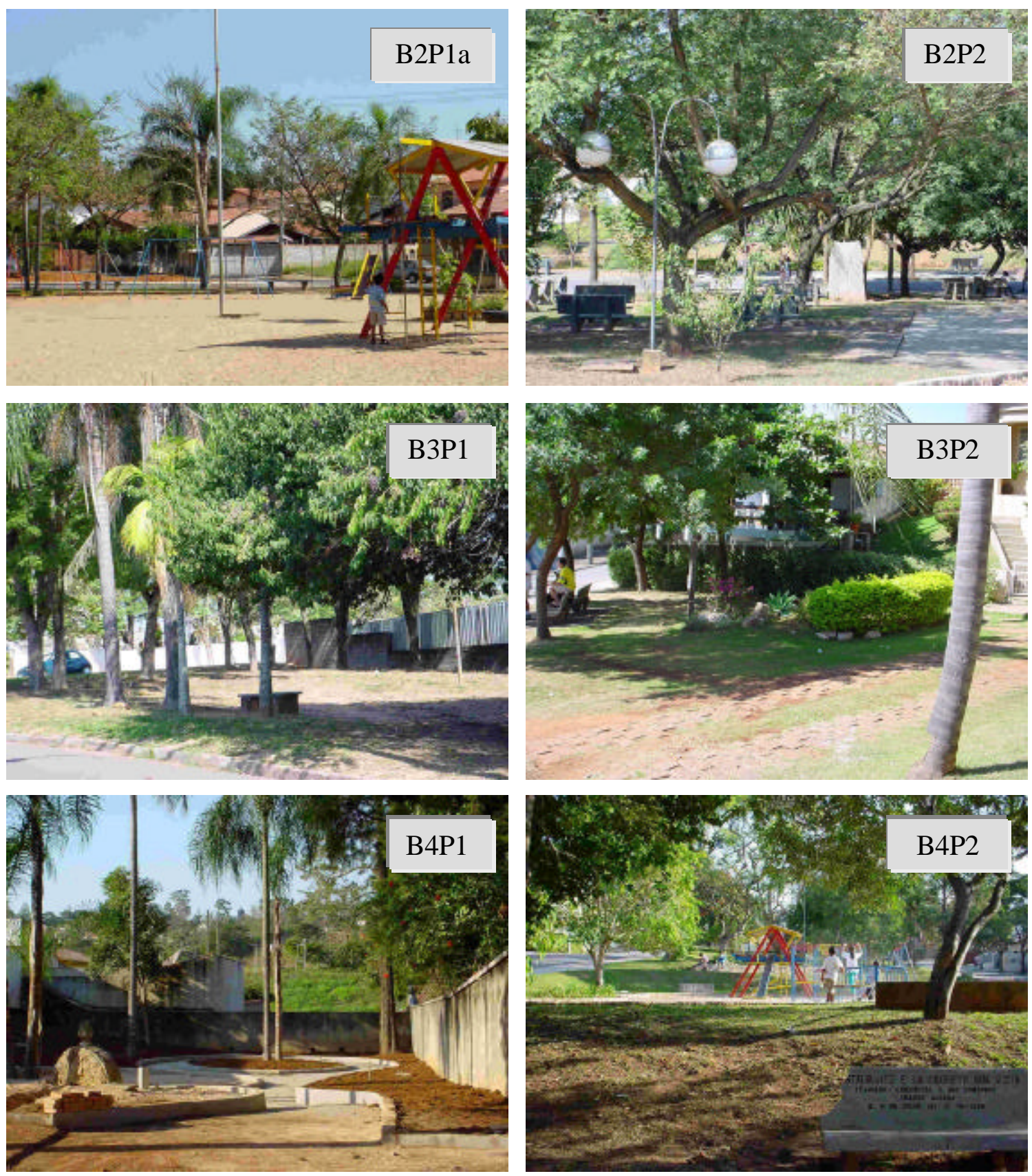

Figura 5 - Aspecto geral do "playground" da praça B2P1 (Aquário) e aspecto geral das praças B2P2 (sem nome), B3P1 (Dom Martinho Albert Roth), B3P2 (da Vitória), B4P1 (Biquinha) e B4P2 (Comendador Paulo Storani) da cidade de Vinhedo (SP), 2002. 

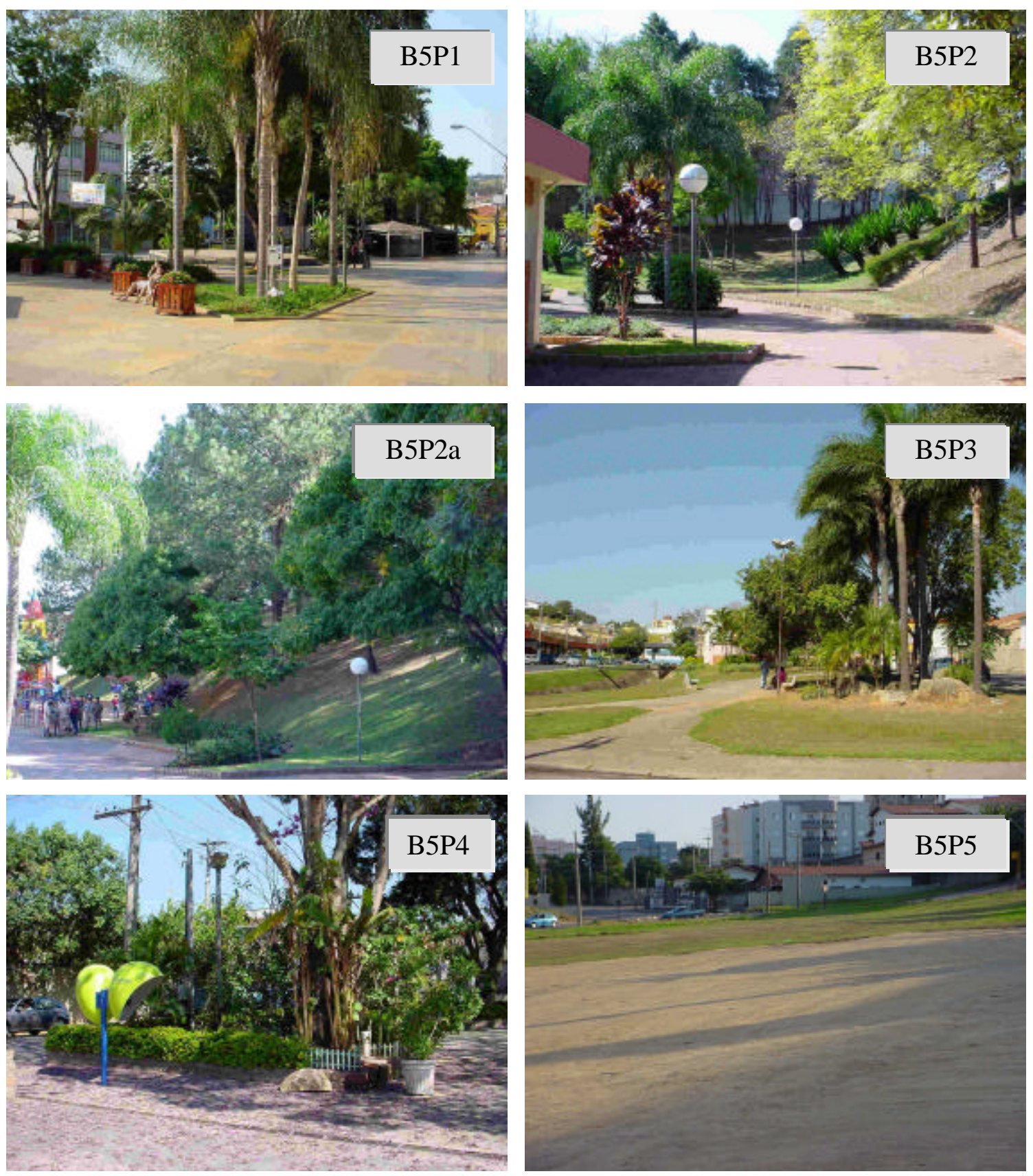

Figura 6 - Aspecto geral das praças B5P1 (Sant'Ana), B5P2 (Centro de Convivência), B5P2a (Centro de Convivência), B5P3 (Corazzari), B5P4 (sem nome) e B5P5 (sem nome) da cidade de Vinhedo (SP), 2002. 

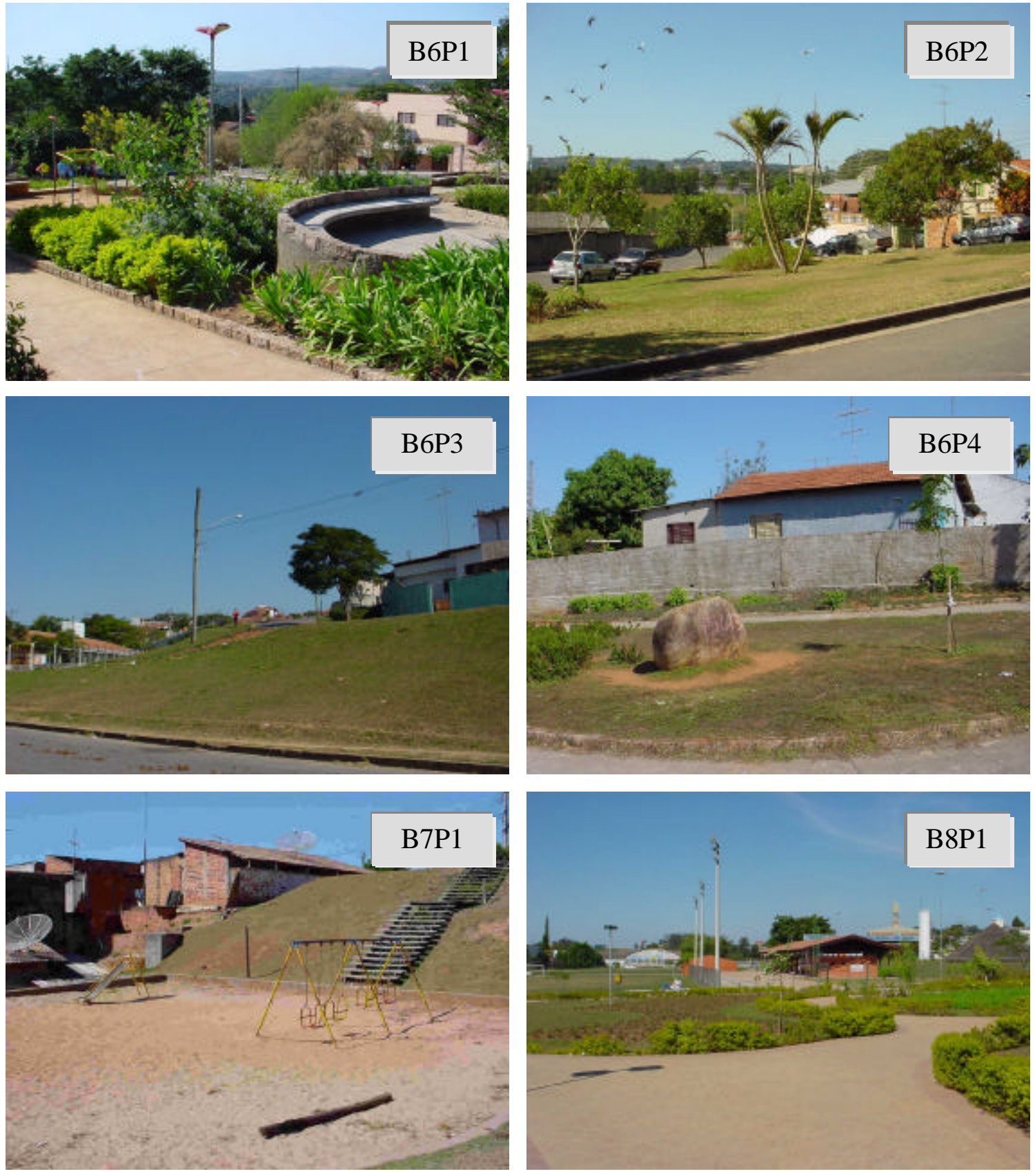

Figura 7 - Aspecto geral das praças B6P1 (Prefeito Jair Mendes de Barros), B6P2 (sem nome), B6P3 (sem nome), B6P4 (sem nome), B7P1 (sem nome) e B8P1 (Centro de Lazer do Trabalhador "Aurora Sudário") da cidade de Vinhedo (SP), 2002. 


\subsection{Praça B8P1 (Centro de Lazer do Trabalhador “Aurora Sudário")}

Localizada no bairro Capela, possui $29.400 \mathrm{~m}^{2}$, apresentando 31 exemplares arbóreos com altura média de 4,51m e CAP médio de $0,37 \mathrm{~m}$, indicando que a área tem arborização jovem. Há grande número de mudas novas com menos de $10 \mathrm{~cm}$ de CAP, por ter sido a praça criada no ano de 1999. Existem 11 bancos de alvenaria, "playground", área para esportes, banheiros, cancha de bocha e acesso para deficientes. É muito utilizada por várias faixas etárias de público e seu volume de utilização é alto. O acesso é fácil, possuindo áreas para estacionamento. Apresenta boa iluminação e pavimentação. Encontra-se em bom estado de conservação (Figura 7).

\subsection{Situação da arborização}

Nas 764 árvores inventariadas com CAP acima de 10cm, os itens analisados foram: espécie, procedência, conformação geral, ocorrência de poda, altura da primeira bifurcação, sanidade e localização geográfica das árvores com uso de GPS (Apêndice).

\subsubsection{Espécie}

Foram encontradas 23 famílias botânicas, divididas em 55 espécies. Destas, 32 indivíduos não foram identificados até o momento.

A Tabela 5 mostra as espécies encontradas, a quantidade de indivíduos por espécie e sua ocorrência (expressa em percentagem) em todas as praças de Vinhedo $(\mathrm{SP})$.

A espécie de maior ocorrência foi Syagrus romanzoffiana (jerivá) com 31,94\%, não ocorrendo apenas nos bairros B6 e B7, seguida por Pinus sp (pinus) com 11,65\%. O restante das espécies não ultrapassou 7\% de ocorrência, valor este que, segundo Grey \& Deneke (1978), está de acordo com a percentagem máxima recomendada de 10 a $15 \%$ por espécie da composição total.

Motta (1998), em Belo Horizonte (MG), também encontrou uma grande diversidade, sendo que, no seu caso, nenhuma espécie contribuiu com mais de $6 \%$. Resultado semelhante foi observado por Rodrigues et al. (1994) em Brasília (DF), que 
não encontraram nenhuma espécie com freqüência superior a 7\%, pois relatam Encontraram, em um universo de 6.515 árvores, um total de 230 espécies.

Tabela 5. Espécies inventariadas em todas as praças de Vinhedo (SP), quantidade de indivíduos por espécie e sua freqüência (expressa em percentagem), no ano 2002.

\begin{tabular}{|c|c|c|c|}
\hline Nome comum & Nome científico & Quantidade & $\begin{array}{c}\text { Freqüência } \\
(\%)\end{array}$ \\
\hline Abacateiro & Persea americana Mill. & 3 & 0,39 \\
\hline Aceroleira & Malpighia glabra L. & 1 & 0,13 \\
\hline Açoita cavalo & Luehea divaricata Mart. & 1 & 0,13 \\
\hline Amoreira & Morus nigra L. & 3 & 0,39 \\
\hline Aroeira-pimenteira & Schinus terebinthifolius Raddi & 14 & 1,83 \\
\hline Aroeira-salsa & Schinus molle L. & 3 & 0,39 \\
\hline Canela & Nectrandra rigida (Kunth.) Nees & 1 & 0,13 \\
\hline Cereja do Rio Grande & Eugenia involucrata DC. & 1 & 0,13 \\
\hline Cerejinha & Ficus microcarpa L. & 1 & 0,13 \\
\hline Cinamomo & Melia azedarach L. & 8 & 1,05 \\
\hline Cipreste italiano & Cupressus sempervirens Lam. & 1 & 0,13 \\
\hline Coração de negro & Poecilanthe parviflora Benth. & 3 & 0,39 \\
\hline Eritrina & Erythrina speciosa Andr. & 1 & 0,13 \\
\hline Espatódea & Spathodea campanulata Beauv. & 36 & 4,71 \\
\hline Eucalipto & Eucayiptus sp. & 2 & 0,26 \\
\hline Falsa murta & Murraya exotica $\mathrm{L}$. & 1 & 0,13 \\
\hline Fênix & Phoenix roebelenii $\mathrm{O}^{\prime}$ Brien & 2 & 0,26 \\
\hline Figueira & Ficus sp. & 1 & 0,13 \\
\hline Figueira benjamina & Ficus benjamina $\mathrm{L}$. & 14 & 1,83 \\
\hline Figueira branca & Ficus pohliana Miq. & 5 & 0,65 \\
\hline Flamboyant & Delonix regia (Boj. Ex Hook.) Raf. & 6 & 0,79 \\
\hline Jerivá & Syagrus romanzoffiana (Cham.) Glassm. & 244 & 31,94 \\
\hline Goiabeira & Psidium guajava $\mathrm{L}$ & 2 & 0,26 \\
\hline Grevília & Grevillea robusta A. Cunn. & 2 & 0,26 \\
\hline Guaraná paulista & Piscidia erythrina 1. & 1 & 0,13 \\
\hline Ipê amarelo & Tabebuia chrysotricha (Mart. ex DC.) Standl. & 45 & 5,89 \\
\hline Ipê de jardim & Stenolobium stans (L.) H. B. \& K. & 1 & 0,13 \\
\hline Ipê roxo & Tabebuia impetiginosa (Mart.) Standl. & 2 & 0,26 \\
\hline Jabuticabeira & Myrciaria cauliflora Berg. & 5 & 0,65 \\
\hline Jacarandá mimoso & Jacaranda mimosaefolia D .Don & 5 & 0,65 \\
\hline Jambolão & Eugenia jambolana Sam. & 1 & 0,13 \\
\hline Jenipapo & Genipa americana $\mathrm{L}$. & 1 & 0,13 \\
\hline Ligustro & Ligustrum japonicum Thumb. & 41 & 5,37 \\
\hline Limoeiro & Citrus aurantifolia Swing. & 1 & 0,13 \\
\hline Mangueira & Mangifera indica $\mathrm{L}$. & 6 & 0,79 \\
\hline Munguba & Pachira aquatica Aubl. & 2 & 0,26 \\
\hline Não identificado & Não identificado & 32 & 4,19 \\
\hline
\end{tabular}


Tabela 5. Espécies inventariadas em todas as praças de Vinhedo (SP), quantidade de indivíduos por espécie e sua freqüência (expressa em percentagem), no ano 2002 (continuação).

\begin{tabular}{|c|c|c|c|}
\hline Nome comum & Nome científico & Quantidade & $\begin{array}{l}\text { Freqüiência } \\
(\%)\end{array}$ \\
\hline Paineira & Chorisia speciosa A. St-Hil. & 16 & 2,09 \\
\hline Palmeira cariota & Caryota urens $\mathrm{L}$. & 1 & 0,13 \\
\hline Palmeira leque & Livistona chinensis (Jacq.) R.Br. & 1 & 0,13 \\
\hline Palmeira seafortia & $\begin{array}{l}\text { Archontophoenix cunninghamiana H. Wendl. } \\
\& \text { Drude }\end{array}$ & 22 & 2,88 \\
\hline Palmeira triangular & Dypsis decaryi (Jum.) Beentje \& J.Dransf. & 16 & 2,09 \\
\hline Pata de vaca & Bauhinia variegata $\mathrm{L}$. & 9 & 1,18 \\
\hline Pata de vaca branca & Bauhinia variegata L. var. candida & 1 & 0,13 \\
\hline Pau-brasil & Caesalpinia echinata Lam. & 9 & 1,18 \\
\hline Pau ferro & $\begin{array}{l}\text { Caesalpinia ferrea Mart. ex Tul.var. } \\
\text { leiostachya Benth. }\end{array}$ & 8 & 1,05 \\
\hline Peroba branca & $\begin{array}{l}\text { Chrysophyllum gonocarpum (Mart. \& Eichl.) } \\
\text { Engl. }\end{array}$ & 1 & 0,13 \\
\hline Pinus & Pinus sp. & 89 & 11,65 \\
\hline Pitangueira & Eugenia uniflora $\mathrm{L}$. & 2 & 0,26 \\
\hline Quaresmeira & Tibouchina granulosa Cogn. & 17 & 2,23 \\
\hline Resedá & Lagerstroemia indica $\mathrm{L}$. & 1 & 0,13 \\
\hline Romã & Punica granatum $\mathrm{L}$. & 1 & 0,13 \\
\hline Sete copas & Terminalia catappa $\mathrm{L}$. & 2 & 0,26 \\
\hline Sibipiruna & Caesalpinia peltophoroides Benth. & 46 & 6,02 \\
\hline Tipuana & Tipuana tipu (Benth.) O. Kuntze & 23 & 3,01 \\
\hline
\end{tabular}

A segunda espécie de maior ocorrência foi Caesalpinia peltophoroides, (sibipiruna) aparecendo em 27,27\% das praças da cidade de Vinhedo. Esta espécie caducifolia tem sido largamente utilizada em arborização urbana que com seus pequenos folíolos, pode causar o entupimento de calhas, causando ocasionais reclamações da população. Sousa et al. (1990), em levantamento realizado nas árvores de rua na cidade de Botucatu (SP), observaram que 70\% das árvores encontradas na parte central e antiga da cidade eram C. peltophoroides. Winters et al. (1992) também observaram alta percentagem de $C$. peltophoroides, 53,22\%, em trabalho realizado em ruas e avenidas em 295 municípios do Estado de São Paulo. O mesmo ocorreu em trabalho realizado por Milano et al. (1992c) em Vitória (ES), onde C. peltophoroides fazia parte de um grupo das três espécies, mais plantadas na cidade, perfazendo um total de 66,90\%. Michi \& 
Couto (1996) trabalhando no município de Piracicaba (SP) e Martins et al. (1992) em levantamento realizado nas ruas de Viçosa (MG), observaram que 17,90\% e 10,65\% respectivamente, das árvores inventariadas eram C. peltophoroides.

A terceira espécie de maior destaque, que ocorreu em 13,64\% das praças de Vinhedo (SP), foi o Ligustrum japonicum. Em Viçosa (MG) esta espécie teve 34,07\% de ocorrência (Martins et al., 1992). O mesmo gênero teve grande ocorrência em Santa Maria (RS) com 20,38\% (Santos \& Teixeira, 1990) e em Curitiba (PR) com 15,40\% (Milano et al. , 1992b), porém não a mesma espécie ocorrida em Vinhedo (SP).

Em nenhuma das áreas inventariadas em Vinhedo (SP) foi encontrada espécie de cerrado, vegetação nativa da região, conforme recomendam Toledo Filho \& Parente (1988) e Barbosa et al. (2001). Porém, segundo Lorenzi (1992), S. romanzoffiana (jerivá) ocorre em quase todas as formações vegetais, e é freqüentemente encontrada em capoeiras e áreas recém abandonadas.

Quando se compararam os bairros, a realidade da diversidade de espécies é outra, pois é possível observar que, além da grande ocorrência de certas espécies, estas se encontram concentradas por bairro, o que pode criar, conforme Milano et al. (1992a), um quadro delicado do ponto de vista fitossanitário, estético e paisagístico.

Na Tabela 6, estão demonstradas as espécies de maior freqüiência distribuídas por praça na cidade de Vinhedo (SP). 
Tabela 6. Espécies de maior freqüência, expressa em percentagem, observadas nas praças de Vinhedo (SP), 2002.

\begin{tabular}{|c|c|c|c|}
\hline Praça & Nome científico & Nome comum & $\begin{array}{c}\text { Freqüência } \\
(\%)\end{array}$ \\
\hline B1P1 & Caesalpinia peltophoroides Benth. & Sibipiruna & 54,55 \\
\hline B1P2 & Caesalpinia peltophoroides Benth. & Sibipiruna & 62,50 \\
\hline B1P3 & Caesalpinia peltophoroides Benth. & Sibipiruna & 61,54 \\
\hline $\mathrm{B} 1 \mathrm{P} 4$ & Caesalpinia peltophoroides Benth. & Sibipiruna & 27,27 \\
\hline B1P5 & Tipuana tipu (Benth.) O. Kuntze & Tipuana & 42,86 \\
\hline $\mathrm{B} 2 \mathrm{P} 1$ & Syagrus romanzoffiana (Cham.) Glassm. & Jerivá & 67,03 \\
\hline $\mathrm{B} 2 \mathrm{P} 2$ & Tipuana tipu (Benth.) O. Kuntze & Tipuana & 46,67 \\
\hline B3P1 & Caesalpinia peltophoroides Benth. & Sibipiruna & 29,41 \\
\hline B3P2 & Syagrus romanzoffiana (Cham.) Glassm. & Jerivá & 68,75 \\
\hline B4P1 & Syagrus romanzoffiana (Cham.) Glassm. & Jerivá & 66,67 \\
\hline \multirow[t]{2}{*}{ B4P2 } & Syagrus romanzoffiana (Cham.) Glassm. & Jerivá & 36,36 \\
\hline & Ligustrum japonicum Thumb. & Ligustro & 36,36 \\
\hline B5P1 & Syagrus romanzoffiana (Cham.) Glassm. & Jerivá & 48,39 \\
\hline B5P2 & Pinus sp. & Pinus & 30,42 \\
\hline B5P3 & Syagrus romanzoffiana (Cham.) Glassm. & Jerivá & 40,00 \\
\hline \multirow[t]{2}{*}{ B5P4 } & Tabebuia chrysotricha (Mart. ex DC.) Standl. & Ipê amarelo & 38,46 \\
\hline & Caesalpinia peltophoroides Benth. & Sibipiruna & 38,46 \\
\hline B5P5* & -- & -- & 0,00 \\
\hline B6P1 & Caesalpinia ferrea Mart. Ex Tul.var. leiostachya Benth. & Pau-ferro & 21,74 \\
\hline B6P2 & Ligustrum japonicum Thumb. & Ligustro & 87,50 \\
\hline В6Р3* & -- & -- & 0,00 \\
\hline B6P4* & -- & -- & 0,00 \\
\hline B7P1 & Ficus benjamina $\mathrm{L}$. & Figueira bejamina & 66,67 \\
\hline B8P1 & Ligustrum japonicum Thumb. & Ligustro & 25,81 \\
\hline
\end{tabular}

* Áreas com indivíduos com CAP menor que 10cm ou que não possuíam árvores

As espécies arbóreas que apresentaram maior freqüência (acima de 10\% por bairro) são apresentadas na Tabela 7. 
Tabela 7. Espécies arbóreas com frequiência acima de 10\%, presentes nos diferentes bairros da cidade de Vinhedo (SP), 2002.

\begin{tabular}{llcc}
\hline Bairro & Nome científico & Quantidade & Freqüência (\%) \\
\hline B1* & Caesalpinia peltophoroides Benth. & 28 & 38,89 \\
B2* & Syagrus romanzoffiana (Cham.) Glassm. & 123 & 62,76 \\
B3* & Caesalpinia peltophoroides Benth. & 10 & 20,00 \\
& Ligustrum japonicum Thumb. & 8 & 16,00 \\
& Syagrus romanzoffiana (Cham.) Glassm. & 13 & 26,00 \\
B4* & Ligustrum japonicum Thumb. & 12 & 26,67 \\
& Syagrus romanzoffiana (Cham.) Glassm. & 20 & 44,44 \\
B5* & Syagrus romanzoffiana (Cham.) Glassm. & 84 & 25,07 \\
B6* & Caesalpinia ferrea Mart. Ex Tul.var. leiostachya Benth. & 5 & 15,63 \\
& Ligustrum japonicum Thumb. & 7 & 21,88 \\
B7* & Ficus benjamina L. & 2 & 66,67 \\
& Schinus molle Linn. & 1 & 33,33 \\
B8* & Ligustrum japonicum Thumb. & 8 & 25,81 \\
& Myrciaria cauliflora Berg. & 5 & 16,13 \\
& Schinus terebinthifolius Raddi & 6 & 19,35
\end{tabular}

* Bairros: B1 João XXIII; B2 Aquário; B3 Santa Rosa; B4 Vila Planalto; B5 Centro; B6 Jardim Três Irmãos; B7 Jardim Von Zuben; Capela

\subsubsection{Procedência}

Analisando-se a procedência das árvores levantadas por praças, observa-se na Tabela 8 que na maioria das praças $(63,64 \%)$ menos de $50 \%$ das espécies são exóticas. A frequiência de espécies nativas e exóticas distribuídas por bairro encontra-se demonstrada na Figura 8.

Observando-se a Figura 8 é possível visualizar que, dos oito bairros estudados, apenas o Bairro 7 possui quantidade maior de espécies exóticas. Este dado, porém, não é de grande relevância, pois a área em questão é apenas uma praça com três exemplares arbóreos. 
Tabela 8. Frequiência das espécies por praças, classificadas em nativas, exóticas e não identificadas, na cidade de Vinhedo (SP), 2002.

\begin{tabular}{lccc}
\hline Praça & Nativa & $\begin{array}{c}\text { Procedência }(\%) \\
\text { Exótica }\end{array}$ & Não identificada \\
\hline B1P1 & 54,55 & 45,45 & 0,00 \\
B1P2 & 62,50 & 37,50 & 0,00 \\
B1P3 & 61,54 & 38,46 & 0,00 \\
B1P4 & 57,58 & 33,33 & 9,09 \\
B1P5 & 14,29 & 85,71 & 0,00 \\
B2P1 & 77,35 & 19,89 & 2,76 \\
B2P2 & 20,00 & 80,00 & 0,00 \\
B3P1 & 41,18 & 47,06 & 11,76 \\
B3P2 & 93,75 & 6,25 & 0,00 \\
B4P1 & 16,67 & 8,33 \\
B4P2 & 75,00 & 48,48 & 12,12 \\
B5P1 & 38,48 & 8,06 \\
B5P2 & 39,39 & 46,67 & 7,92 \\
B5P3 & 56,45 & 45,00 & 5,00 \\
B5P4 & 45,42 & 0,00 & 0,00 \\
B5P5 & 50,00 & 0,00 & 0,00 \\
B6P1 & 100,00 & 8,33 & 54,17 \\
B6P2 & 0,00 & 87,50 & 12,50 \\
B6P3 & 37,50 & 0,00 & 0,00 \\
B6P4 & 0,00 & 0,00 & 0,00 \\
B7P1 & 0,00 & 66,67 & 0,00 \\
B8P1 & 0,00 & 32,26 & 0,00 \\
\hline & 33,33 & &
\end{tabular}

\subsubsection{Conformação geral}

Como conformação geral foram, analisados CAP, altura da $1^{\text {a }}$ bifurcação, formato e diâmetro da copa, para verificação da manutenção das características naturais e condução apropriada de cada espécie.

A Figura 9 mostra a ocorrência de plantas com conformação geral normal e anormal distribuídas por bairro. Pode-se observar que, em todos os bairros, a maioria dos indivíduos apresentou conformação geral normal, demostrando a prática de tratos culturais adequados. 


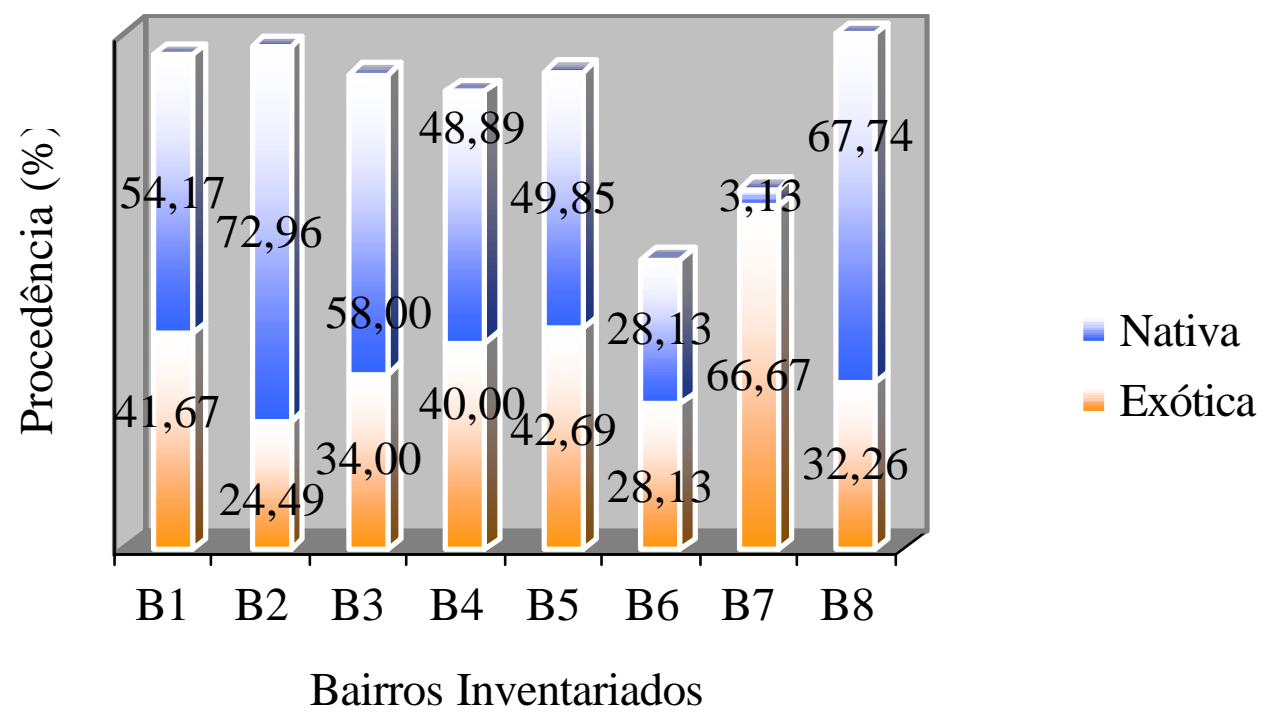

Figura 8 - Frequiência de espécies distribuídas por bairro e classificadas, em nativas e exóticas presentes na cidade de Vinhedo (SP), 2002.

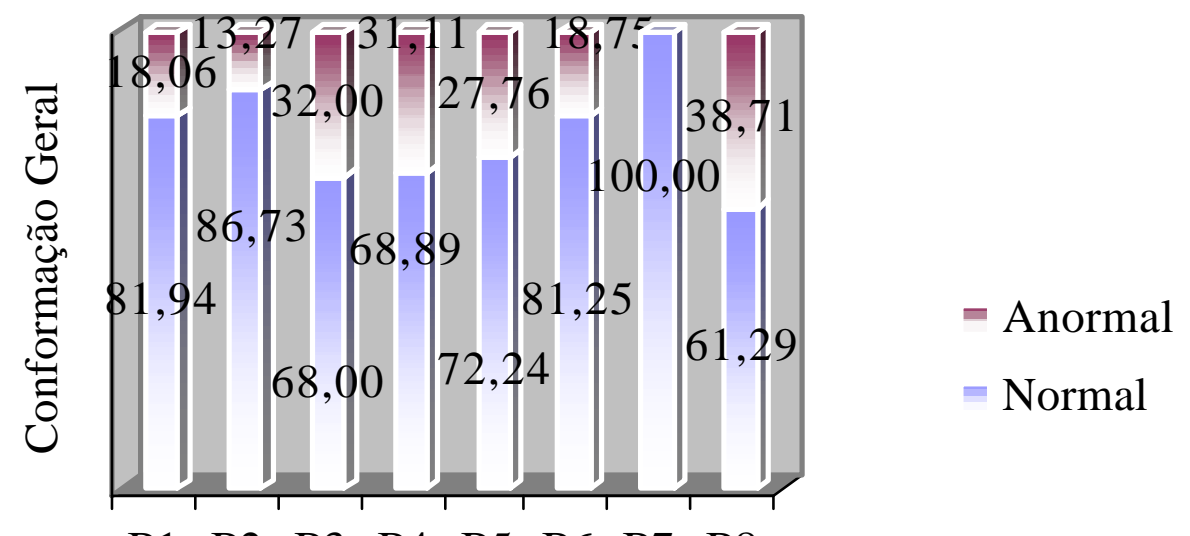

$\begin{array}{lllllllll}\text { B1 } & \text { B2 } & \text { B3 } & \text { B4 } & \text { B5 } & \text { B6 } & \text { B7 } & \text { B8 }\end{array}$

Bairros Inventariados

Figura 9 - Conformação geral das árvores, expressos em percentagem, presentes nas praças existentes nos bairros inventariados da cidade de Vinhedo (SP), 2002. 


\subsubsection{Ocorrência de podas}

A execução correta de podas de condução é, em grande parte, responsável pela manutenção das características naturais de cada indivíduo. Na Figura 10, pode-se notar que, na maioria dos casos, as podas foram feitas corretamente ou não houve a necessidade de nenhuma intervenção. Poucos foram os casos em que se aplicaram podas drásticas.

As plantas que não apresentaram podas foram, em sua maioria, palmeiras, que normalmente não aceitam intervenção dessa natureza.

Martins et al. (1992) observaram que 34,58\% das árvores inventariadas em Viçosa (MG) sofreram podas de limpeza (condução) e $23,71 \%$ poda total (drástica). Milano et al. (1992c) constataram que 42,30\% das árvores de ruas de Vitória (ES) sofreram podas que causaram mutilações diversas (poda drástica) e favoreceram apenas a fiação. Trindade \& Rocha (1990) verificaram que apenas 6,29\% dos indivíduos analisados na cidade de Curitiba (PR) apresentavam podas drásticas. Andrade (2002), em levantamento realizado na arborização viária da cidade de Campos do Jordão (SP), observou que $59,30 \%$ das árvores sofreram poda drástica e $81,80 \%$ sofreram poda de condução, sendo que apenas $18,20 \%$ não foram podadas.

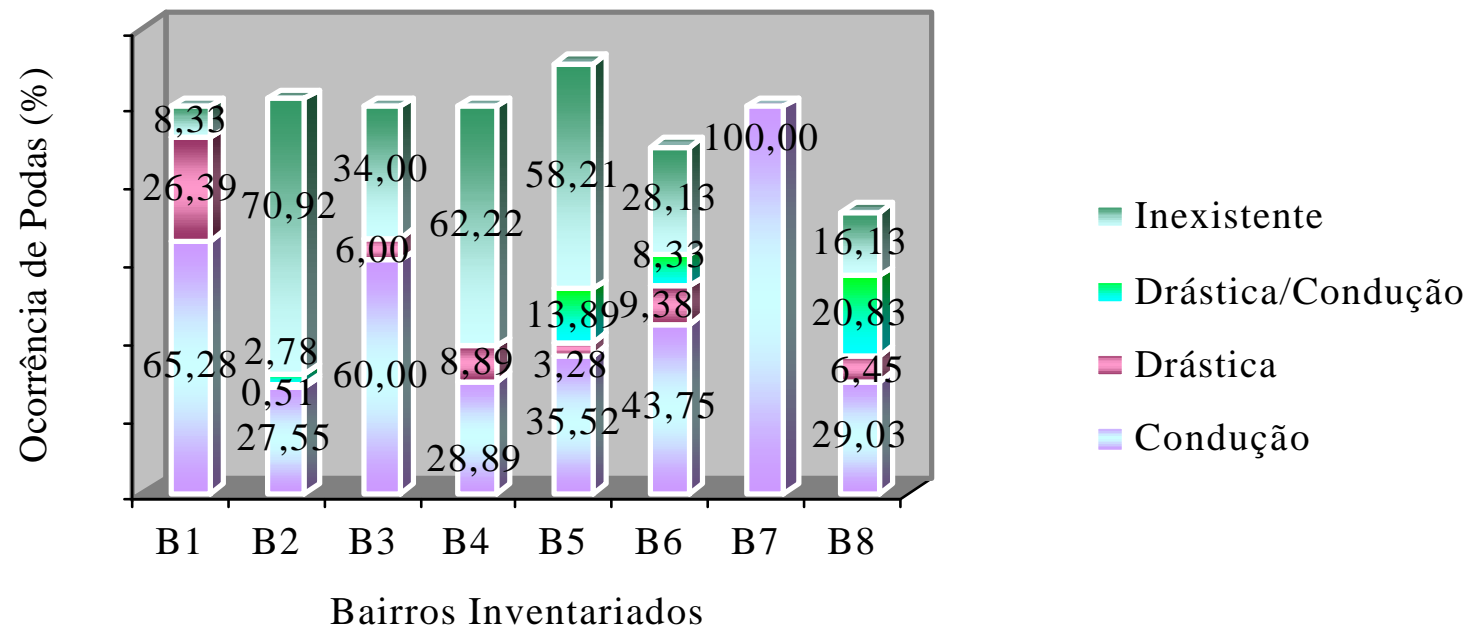

Figura 10 - Tipos de podas executadas nas árvores dos diferentes bairros (B1 a B8) das praças da cidade de Vinhedo (SP), 2002. 


\subsubsection{Altura da primeira bifurcação}

Em relação à altura de primeira bifurcação, verificou-se grande proporção de árvores com primeira ramificação abaixo de $2 \mathrm{~m}$, conforme se vê na Figura 11, porém estas plantas se encontram, na maioria dos casos, fora da área de circulação, portanto sem causar problemas aos pedestres ou veículos.

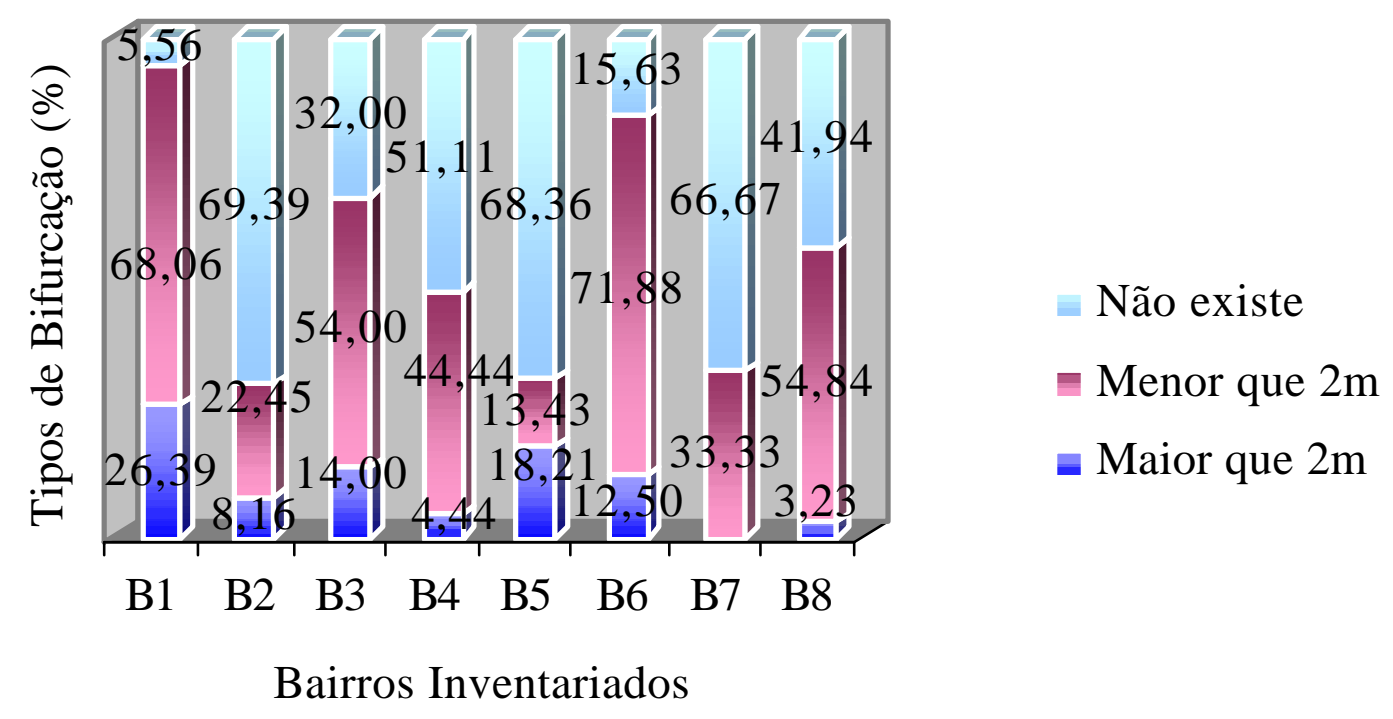

Figura 11 - Altura da primeira bifurcação observada em árvores existentes nas praças dos diferentes bairros (B1 a B8) da cidade de Vinhedo (SP), 2002.

\subsubsection{Sanidade}

Em Vinhedo 50,15\% das árvores inventariadas estavam saudáveis, 42,54\% eram recuperáveis e 7,33\% eram irrecuperáveis. Costa \& Higuchi (1999) em levantamento realizado na arborização de ruas de Manaus (AM) observaram que $10 \%$ das árvores estavam boas (saudáveis), 74\% regulares (recuperáveis) e 16\% ruins (irrecuperáveis). Milano et al. (1992b) encontraram 39,4\% de árvores em bom estado fitossanitário, $54,4 \%$ de árvores em estado satisfatório, 5\% ruim e 1,2\% de árvores mortas ou em estado irrecuperável em Curitiba (PR); Santos et al. (1991) em trabalho realizado em 
Bento Gonçalves (RS), encontram que $64,80 \%$ das árvores das ruas do centro estavam saudáveis; $21,49 \%$ recuperáveis e 13,71\% irrecuperáveis.

Os resultados obtidos foram distribuídos por bairro, conforme demonstrado na Figura 12. As plantas classificadas como "saudáveis" só necessitam de cuidados de manutenção, enquanto a classe "recuperável" indica a necessidade de intervenções direcionadas tais como podas de condução e tratamento fitossanitário e as “irrecuperáveis” deverão ser substituídas.

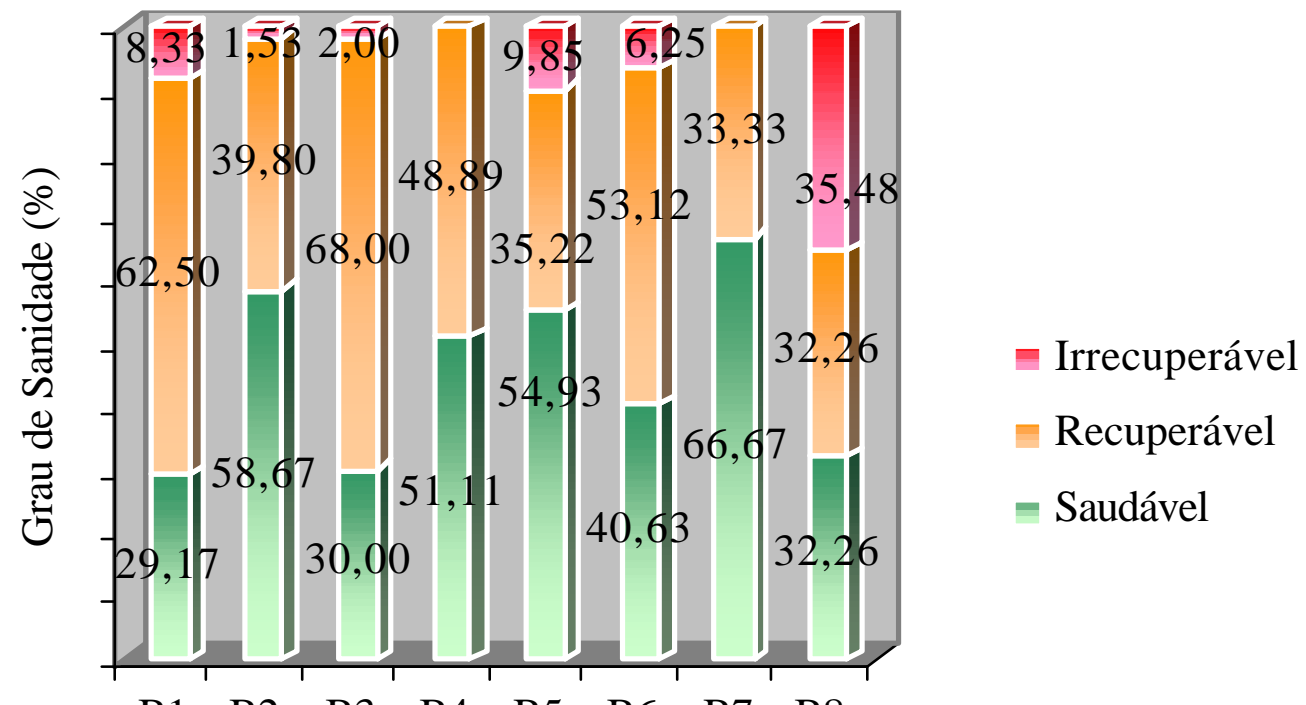

$\begin{array}{llllllll}\text { B1 } & \text { B2 } & \text { B3 } & \text { B4 } & \text { B5 } & \text { B6 } & \text { B7 } & \text { B8 }\end{array}$

Bairros Inventariados

Figura 12 - Grau de sanidade apresentado pelas árvores existentes nas praças dos diferentes bairros (B1 a B8) da cidade de Vinhedo (SP), 2002.

Pode-se observar, na Figura 12, que apenas o Bairro 8 apresentou alta percentagem de árvores irrecuperáveis $(35,48 \%)$, porém este fato é explicável, por se tratarem de exemplares antigos que foram mantidos após a implantação da Praça B8P1, sendo que estes indivíduos se apresentaram altamente debilitados.

Na Tabela 9 pode-se observar o grau de sanidade das árvores, classificado como saudável, recuperável e irrecuperável, nas praças de Vinhedo (SP). 
Tabela 9. Grau de sanidade (expresso em percentagem) das árvores, classificado como saudável, recuperável e irrecuperável, nas praças da cidade de Vinhedo (SP), 2002.

\begin{tabular}{lccc}
\hline Praça & Saudável & $\begin{array}{c}\text { Grau de Sanidade (\%) } \\
\text { Recuperável }\end{array}$ & Irrecuperável \\
\hline B1P1 & 45,45 & 36,36 & 18,18 \\
B1P2 & 12,50 & 87,50 & 0,00 \\
B1P3 & 30,77 & 53,85 & 15,38 \\
B1P4 & 33,33 & 63,64 & 3,03 \\
B1P5 & 0,00 & 85,71 & 14,29 \\
B2P1 & 62,98 & 36,46 & 0,55 \\
B2P2 & 6,67 & 80,00 & 13,33 \\
B3P1 & 14,71 & 82,35 & 2,94 \\
B3P2 & 62,50 & 37,50 & 0,00 \\
B4P1 & 75,00 & 25,00 & 0,00 \\
B4P2 & 42,42 & 57,58 & 0,00 \\
B5P1 & 82,26 & 17,74 & 0,00 \\
B5P2 & 46,25 & 40,83 & 12,92 \\
B5P3 & 70,00 & 20,00 & 10,00 \\
B5P4 & 61,54 & 38,46 & 0,00 \\
B5P5 & 0,00 & 0,00 & 0,00 \\
B6P1 & 41,67 & 50,00 & 8,33 \\
B6P2 & 37,50 & 62,50 & 0,00 \\
B6P3 & 0,00 & 0,00 & 0,00 \\
B6P4 & 0,00 & 0,00 & 0,00 \\
B7P1 & 66,67 & 33,33 & 0,00 \\
B8P1 & 32,26 & 32,26 & 35,48 \\
\hline
\end{tabular}

A praça B5P1 apresentou a maior percentagem de árvores saudáveis $(82,26 \%)$, apesar de ser a praça mais antiga da cidade indicando que foram utilizadas técnicas adequadas de manejo. A praça B1P2 apresentou a maior quantidade de árvores recuperáveis $(87,50 \%)$, o que mostrou a necessidade de melhoria das técnicas utilizadas de manejo e a praça B8P1 apresentou a maior percentagem de árvores irrecuperáveis $(35,48 \%)$, o que foi justificado pela presença de árvores antigas que foram mantidas na implantação da praça, porém sem a forma de condução adequada. 


\subsection{Infra-estrutura}

Das 22 praças levantadas, 19 possuíam boa infra-estrutura. Em todas, foram analisados os itens: pavimentação, iluminação e existência de equipamentos e construções. Os resultados obtidos foram:

- pavimentação: presente em $81,81 \%$ das praças (todas em bom estado), e inexistente em $18,19 \%$.

- iluminação: 54,54\% das praças apresentavam boa iluminação, 13,64\% estavam em situação regular, 4,55\% em estado ruim e 27,27\% apresentavam-se sem iluminação;

- equipamentos e construções: 81,82\% das áreas inventariadas possuíam algum tipo de equipamento, como banco, parque de diversão infantil, áreas para esporte, sanitários, pergolados, viveiros de pássaros, coreto e outros (vide item 4.1.1.1 Descrição das praças analisadas) e 18,18\% não apresentaram nenhum tipo.

As praças consideradas incompletas totalizaram 13,64\% e são aquelas que se apresentaram sem arborização, arbustos ou mesmo canteiros, o que ocasionava desequilíbrio paisagístico. Milano et al. (1992c) encontraram 48,07\% das áreas consideradas incompletas em Vitória (ES).

Comparando-se os resultados obtidos com o trabalho realizado por Carvalho (2001) na cidade de Lavras (MG), pode-se observar que 33,3\% das áreas apresentavam pavimentação em bom estado de conservação, contra 81,81 \% de Vinhedo (SP). Milano et al. (1992c), em levantamento realizado na cidade de Vitória (ES), observaram que 54 $(29,83 \%)$ delas estavam com pavimentação em bom estado, 60 (55,25\%) em estado regular, 50 (27,62\%) em estado ruim e 17 (9,39\%) não possuíam pavimentação.

Em Vinhedo (SP), 54,54\% das praças apresentavam uma boa iluminação, contra apenas 47\% em Lavras (Carvalho, 2001). Em Vitória, 43,05\% apresentaram uma boa iluminação, 13,81\% estavam em situação regular, 13,81\% em estado ruim e 29,28\% não possuíam iluminação (Milano et al., 1992c).

Comparando-se as praças B5P5, B6P2, B6P3 e B6P4, que não apresentaram equipamentos e são áreas deficientes em vegetação, com o trabalho de Carvalho (2001), observa-se que em Lavras, as praças que não possuíam equipamentos apresentavam 
algum tipo de vegetação, oferecendo uma função contemplativa, o que não ocorreu na cidade de Vinhedo. Milano et al. (1992c) constataram que 60,77\% das áreas levantadas apresentaram algum tipo de equipamento, tais como bancos áreas de recreação, sanitários, lanchonetes, comércio ambulante, bebedouros, fontes e outros.

$\mathrm{Na}$ Tabela 10 pode-se observar a distribuição dos itens pavimentação, iluminação, equipamentos e construções, nos diferentes bairros e nas respectivas praças de Vinhedo.

Tabela 10. Existência de pavimentação, iluminação, equipamentos e construções (expressos em percentagem) nas praças dos diferentes bairros (B1 a B8) da cidade de Vinhedo (SP), 2002.

\begin{tabular}{lccc}
\hline Bairro & Pavimentação (\%) & Iluminação (\%) & $\begin{array}{c}\text { Equipamentos e } \\
\text { construções (\%) }\end{array}$ \\
\hline B1 & 100 & 80 & 100 \\
B2 & 100 & 100 & 100 \\
B3 & 50 & 100 & 100 \\
B4 & 100 & 100 & 100 \\
B5 & 80 & 80 & 80 \\
B6 & 50 & 75 & 25 \\
B7 & 100 & 0 & 100 \\
B8 & 100 & 100 & 100 \\
\hline
\end{tabular}

Os bairros B5 e B6 apresentam praças com infra-estrutura inferior quando comparados aos outros bairros, pois em nenhum dos itens avaliados (pavimentação, iluminação, equipamentos e construções), estes bairros apresentaram $100 \%$ de ocorrência. Em compensação, os bairros B2, B4 e B8 apresentaram 100\% de ocorrência nos três itens analisados, demostrando melhor qualidade nas implantações dessas áreas e na sua manutenção.

A Tabela 11 mostra a ocorrência dos mesmos itens (pavimentação, iluminação e equipamentos e construções), porém observados em cada praça. É possível observar que a praça B5P5 necessita de intervenção urgente, pois não apresenta condições mínimas de uso. As praças B1P5, B5P5, B6P2, B6P3, B6P4 e B7P1 necessitam de poste de iluminação com urgência, principalmente por questões de segurança. 
Tabela 11. Existência de pavimentação, iluminação, equipamentos e construções nas praças dos diferentes bairros (B1 a B8) da cidade de Vinhedo (SP), 2002.

\begin{tabular}{|c|c|c|c|}
\hline Praças & Pavimentação & Iluminação & $\begin{array}{c}\text { Equipamentos e } \\
\text { construções }\end{array}$ \\
\hline $\mathrm{B} 1 \mathrm{P} 1$ & $\operatorname{sim}$ & Sim & $\operatorname{sim}$ \\
\hline B1P2 & $\operatorname{sim}$ & Sim & $\operatorname{sim}$ \\
\hline B1P3 & $\operatorname{sim}$ & Sim & $\operatorname{sim}$ \\
\hline B1P4 & $\operatorname{sim}$ & Sim & $\operatorname{sim}$ \\
\hline B1P5 & $\operatorname{sim}$ & Não & $\operatorname{sim}$ \\
\hline B2P1 & $\operatorname{sim}$ & $\operatorname{sim}$ & $\operatorname{sim}$ \\
\hline $\mathrm{B} 2 \mathrm{P} 2$ & $\operatorname{sim}$ & $\operatorname{sim}$ & $\operatorname{sim}$ \\
\hline B3P1 & não & $\operatorname{sim}$ & $\operatorname{sim}$ \\
\hline B3P2 & $\operatorname{sim}$ & $\operatorname{sim}$ & $\operatorname{sim}$ \\
\hline B4P1 & $\operatorname{sim}$ & $\operatorname{sim}$ & $\operatorname{sim}$ \\
\hline B4P2 & $\operatorname{sim}$ & $\operatorname{sim}$ & $\operatorname{sim}$ \\
\hline B5P1 & $\operatorname{sim}$ & $\operatorname{sim}$ & $\operatorname{sim}$ \\
\hline B5P2 & $\operatorname{sim}$ & $\operatorname{sim}$ & $\operatorname{sim}$ \\
\hline B5P3 & $\operatorname{sim}$ & $\operatorname{sim}$ & $\operatorname{sim}$ \\
\hline B5P4 & $\operatorname{sim}$ & $\operatorname{sim}$ & $\operatorname{sim}$ \\
\hline B5P5 & não & não & não \\
\hline B6P1 & $\operatorname{sim}$ & $\operatorname{sim}$ & $\operatorname{sim}$ \\
\hline B6P2 & $\operatorname{sim}$ & não & não \\
\hline B6P3 & $\operatorname{sim}$ & não & não \\
\hline B6P4 & $\operatorname{sim}$ & não & não \\
\hline B7P1 & $\operatorname{sim}$ & não & $\operatorname{sim}$ \\
\hline B8P1 & $\operatorname{sim}$ & $\operatorname{sim}$ & $\operatorname{sim}$ \\
\hline
\end{tabular}

Na Tabela 12, estão listadas as praças que apresentaram alguma infra-estrutura e indicados os equipamentos existentes. 
Tabela 12. Relação das praças da cidade de Vinhedo (SP) com seus equipamentos, 2002.

\begin{tabular}{|c|c|c|c|c|c|c|c|c|c|c|c|c|}
\hline Praça & Banco & Playground & $\begin{array}{c}\text { Área } \\
\text { de } \\
\text { Esportes }\end{array}$ & $\begin{array}{c}\text { Espelho } \\
\text { d'água }\end{array}$ & Fonte & Pérgula & $\begin{array}{c}\text { Quadra } \\
\text { esportiva }\end{array}$ & Banheiro & Construções & Lixeira & $\begin{array}{c}\begin{array}{c}\text { Telefone } \\
\text { público }\end{array} \\
\end{array}$ & $\begin{array}{c}\begin{array}{c}\text { Ausência } \\
\text { de } \\
\text { equipamentos }\end{array} \\
\end{array}$ \\
\hline $\begin{array}{l}\mathrm{B} 1 \mathrm{P} 1 \\
\mathrm{D} 1 \mathrm{D}\end{array}$ & $\begin{array}{l}\mathrm{X} \\
\mathrm{X}\end{array}$ & & & & & & & & & & & \\
\hline B1P2 & $\mathrm{X}$ & & & & & & & & & & & \\
\hline B1P3 & $\mathrm{X}$ & $\mathrm{X}$ & & & & & & & & & & \\
\hline B1P4 & $\mathrm{X}$ & & & & & & & & & & & \\
\hline B1P5 & $X$ & & & & & & & & & & & \\
\hline B2P1 & $\mathrm{X}$ & $\mathrm{X}$ & $\mathrm{X}$ & $\mathrm{X}$ & $\mathrm{X}$ & $\mathrm{X}$ & & $\mathrm{X}$ & $\mathrm{X}$ & $\mathrm{X}$ & & \\
\hline B2P2 & $\mathrm{X}$ & & & & & & & & $\mathrm{X}$ & $\mathrm{X}$ & & \\
\hline B3P1 & $\mathrm{X}$ & & & & & & & & & & & \\
\hline B3P2 & $\mathrm{X}$ & & & & & & & & & & & \\
\hline B4P1 & $\mathrm{X}$ & & & & & & & & $\mathrm{X}$ & & & \\
\hline B4P2 & $\mathrm{X}$ & $\mathrm{X}$ & & & & & & & & & & \\
\hline B5P1 & $X$ & & & $\mathrm{X}$ & & & & $X$ & $X$ & $X$ & $X$ & \\
\hline B5P2 & $\mathrm{X}$ & $\mathrm{X}$ & & & & & & & $\mathrm{X}$ & $\mathrm{X}$ & $\mathrm{X}$ & \\
\hline B5P3 & $\mathrm{X}$ & & & & & & & & & & & \\
\hline B5P4 & $\mathrm{X}$ & & & & & & & & & & $\mathrm{X}$ & \\
\hline B5P5 & & & & & & & & & & & & $\mathrm{X}$ \\
\hline B6P1 & $\mathrm{X}$ & $\mathrm{X}$ & & & & $\mathrm{X}$ & & & $\mathrm{X}$ & & & \\
\hline B6P2 & & & & & & & & & & & & $\mathrm{X}$ \\
\hline В6P3 & & & & & & & & & & & & $\mathrm{X}$ \\
\hline B6P4 & & & & & & & & & & & & $\mathrm{X}$ \\
\hline B7P1 & & $X$ & & & & & & & & & & \\
\hline B8P1 & $\mathrm{X}$ & $\mathrm{X}$ & $\mathrm{X}$ & & & & $\mathrm{X}$ & $\mathrm{X}$ & $\mathrm{X}$ & $\mathrm{X}$ & & \\
\hline
\end{tabular}




\subsubsection{Limpeza e estado de conservação de elementos naturais e construídos}

A limpeza e o estado de conservação de construções, arbustos, canteiros e gramados foram classificados em bom, razoável, ruim e inexistente.

A Tabela 13 mostra que as praças em B1 apresentaram 60\% de seus gramados, $20 \%$ dos canteiros, $40 \%$ dos arbustos, $60 \%$ da limpeza e $20 \%$ das construções em bom estado. Um total de $60 \%$ das praças não apresentaram canteiros e $80 \%$ não possuíam construções.

Em B2, 50\% dos gramados, $50 \%$ dos arbustos, $100 \%$ da limpeza e 100\% das construções estavam em bom estado. Todos os itens foram encontrados nas praças.

Em B3 o único item classificado como em bom estado foi o dos arbustos. Já em B4, os gramados, canteiros, arbustos e a limpeza, apresentam $50 \%$ de estado bom, ficando apenas o item "construções" classificado como ruim e inexistente.

Nos Bairros B5 e B6, todos os itens apresentaram-se em bom estado de conservação.

Em B7, apenas os gramados apresentaram-se em bom estado de conservação, porém é necessário ressaltar que existe somente uma pequena praça neste Bairro. Em B8, ocorre a mesma situação que em B7, porém, por ser uma área de grande interesse da população, o seu estado geral de conservação é muito bom.

No total de 22 praças, apenas cinco apresentam bom estado geral de conservação de elementos naturais e construídos, sendo que os Bairros B1, B2 e B5 apresentam apenas uma praça com a mesma classificação, enquanto B5 possui duas praças nesta situação.

Comparando-se com os dados de Carvalho (2001), verifica-se que em Lavras (MG), 9\% das áreas possuem algum tipo de delimitação dos canteiros, enquanto em Vinhedo (SP), 50\% dos canteiros apresentam-se delimitados. 
Tabela 13. Limpeza e estado de conservação de elementos naturais e construídos das praças do município de Vinhedo (SP), 2002 (dados em percentagem).

\begin{tabular}{|c|c|c|c|c|c|}
\hline Bairro & Elementos & $\operatorname{Bom}(\%)$ & Razoável (\%) & Ruim (\%) & Inexistente (\%) \\
\hline \multirow[t]{5}{*}{ B1 } & Gramados & 60 & 0 & 40 & 0 \\
\hline & Canteiros & 20 & 20 & 0 & 60 \\
\hline & Arbustos & 40 & 0 & 20 & 40 \\
\hline & Construções & 20 & 0 & 0 & 80 \\
\hline & Limpeza & 60 & 40 & 0 & 0 \\
\hline \multirow[t]{5}{*}{ B2 } & Gramados & 50 & 50 & 0 & 0 \\
\hline & Canteiros & 50 & 0 & 50 & 0 \\
\hline & Arbustos & 100 & 0 & 0 & 0 \\
\hline & Construções & 100 & 0 & 0 & 0 \\
\hline & Limpeza & 100 & 0 & 0 & 0 \\
\hline \multirow[t]{5}{*}{ B3 } & Gramados & 0 & 50 & 50 & 0 \\
\hline & Canteiros & 0 & 0 & 50 & 50 \\
\hline & Arbustos & 50 & 0 & 0 & 50 \\
\hline & Construções & 0 & 0 & 0 & 100 \\
\hline & Limpeza & 0 & 50 & 50 & 0 \\
\hline \multirow[t]{5}{*}{ B4 } & Gramados & 50 & 0 & 50 & 0 \\
\hline & Canteiros & 50 & 0 & 50 & 0 \\
\hline & Arbustos & 50 & 50 & 0 & 0 \\
\hline & Construções & 0 & 0 & 50 & 50 \\
\hline & Limpeza & 50 & 0 & 50 & 0 \\
\hline \multirow[t]{5}{*}{ B5 } & Gramados & 80 & 0 & 20 & 0 \\
\hline & Canteiros & 80 & 0 & 0 & 20 \\
\hline & Arbustos & 40 & 60 & 0 & 0 \\
\hline & Construções & 40 & 0 & 0 & 60 \\
\hline & Limpeza & 40 & 60 & 0 & 0 \\
\hline \multirow[t]{5}{*}{ B6 } & Gramados & 50 & 0 & 0 & 50 \\
\hline & Canteiros & 0 & 50 & 25 & 25 \\
\hline & Arbustos & 50 & 0 & 0 & 50 \\
\hline & Construções & 25 & 0 & 0 & 75 \\
\hline & Limpeza & 50 & 50 & 0 & 0 \\
\hline
\end{tabular}


Tabela 13. Limpeza e estado de conservação de elementos naturais e construídos das praças do município de Vinhedo, 2002 (dados em percentagem) (continuação).

\begin{tabular}{llcccc}
\hline Bairro & Elementos & Bom (\%) & Razoável (\%) & Ruim (\%) & Inexistente (\%) \\
\hline B7 & Gramados & 100 & 0 & 0 & 0 \\
& Canteiros & 0 & 0 & 0 & 0 \\
& Arbustos & 0 & 0 & 0 & 100 \\
& Construções & 0 & 0 & 0 & 0 \\
B8 & Limpeza & 0 & 100 & 0 & 0 \\
& Gramados & 100 & 0 & 0 & 0 \\
& Canteiros & 100 & 0 & 0 & 0 \\
& Arbustos & 100 & 0 & 0 & 0 \\
& Construções & 100 & 0 & 0 & 0 \\
\hline
\end{tabular}




\subsubsection{Estado de consolidação da vegetação arbórea}

Após a análise dos dados inventariados pode-se observar que 68,18\% das praças da cidade apresentam árvores com altura superior a $6 \mathrm{~m}$ e CAP acima de $50 \mathrm{~cm}$, mostrando que são áreas que necessitam apenas de procedimentos de manutenção de rotina; $22,72 \%$ das áreas necessitam de práticas de manutenção mais direcionadas ao desenvolvimento das plantas, tais como adubações periódicas, capina, podas de condução; e 13,64\% das praças devem sofrer intervenções tanto de manutenção como de recuperação por meio de novos plantios, ou mesmo, de planejamento para remodelação da área.

$\mathrm{Na}$ Tabela 14, foram apresentados os valores médios de altura e CAP para cada bairro inventariado.

Tabela 14. Valores médios de CAP (circunferência a altura do peito), altura $(\mathrm{H})$ das árvores inventariadas e estado de consolidação das praças, na cidade de Vinhedo (SP), 2002.

\begin{tabular}{lccc}
\hline Praça & CAP médio $(\mathbf{m})$ & H média $(\mathbf{m})$ & Estado de consolidação* \\
\hline B1P1 & 1,50 & 11,94 & $\mathrm{C}$ \\
B1P2 & 1,45 & 12,01 & $\mathrm{C}$ \\
B1P3 & 1,35 & 13,24 & $\mathrm{C}$ \\
B1P4 & 0,65 & 6,80 & $\mathrm{C}$ \\
B1P5 & 1,20 & 8,83 & $\mathrm{C}$ \\
B2P1 & 0,70 & 6,80 & $\mathrm{C}$ \\
B2P2 & 0,83 & 8,42 & $\mathrm{C}$ \\
B3P1 & 0,83 & 8,31 & $\mathrm{C}$ \\
B3P2 & 0,73 & 8,46 & $\mathrm{C}$ \\
B4P1 & 0,78 & 9,73 & $\mathrm{C}$ \\
B4P2 & 0,80 & 6,52 & $\mathrm{C}$ \\
B5P1 & 0,92 & 7,32 & $\mathrm{C}$ \\
B5P2 & 0,72 & 8,73 & $\mathrm{C}$ \\
B5P3 & 0,66 & 5,65 & $\mathrm{~B}$ \\
B5P4 & 0,79 & 8,01 & $\mathrm{C}$ \\
B5P5 & 0,00 & 0,00 & $\mathrm{~A}$ \\
B6P1 & 0,49 & 5,41 & $\mathrm{~B}$ \\
B6P2 & 0,34 & 4,35 & $\mathrm{~B}$ \\
B6P3 & 0,00 & 0,00 & $\mathrm{~A}$ \\
B6P4 & 0,00 & 0,00 & $\mathrm{~A}$ \\
B7P1 & 0,13 & 2,50 & $\mathrm{~B}$ \\
B8P1 & 0,34 & 4,35 & $\mathrm{~B}$ \\
\hline *A: & &
\end{tabular}

* A: não consolidada; B: em consolidação; C: consolidada 
As áreas analisadas foram classificadas em três tipos, nos diferentes bairros (B1 a B8) ,em não consolidada, em consolidação e consolidada, como mostra a Tabela 15.

Tabela 15. Estado de consolidação da vegetação arbórea, das praças dos bairros de Vinhedo (SP), 2002.

\begin{tabular}{lccc}
\hline Bairro & Não consolidada & Em consolidação & Consolidada \\
\hline B1 & 0 & 0 & 5 \\
B2 & 0 & 0 & 2 \\
B3 & 0 & 0 & 2 \\
B4 & 0 & 0 & 3 \\
B5 & 1 & 1 & 3 \\
B6 & 2 & 2 & 0 \\
B7 & 0 & 1 & 0 \\
B8 & 0 & 1 & 0 \\
\hline
\end{tabular}

\subsubsection{Classificação das praças em categorias}

As praças foram classificadas em diversas categorias de acordo com os índices urbanísticos para espaços livres, conforme o modelo de Jantzen citado por Cavalheiro \& Del Picchia (1992), obtendo-se o seguinte resultado:

- $\quad 86,36 \%$ das praças enquadram-se na categoria "vizinhança", pelo tamanho da área;

- $\quad 13,64 \%$ das áreas encaixaram-se na categoria "parque de bairro".

A classificação por categoria de cada praça pode ser observada na Tabela 16. 
Tabela 16. Área total e classificação por categoria das praças existentes nos diferentes bairros da cidade de Vinhedo (SP), 2002.

\begin{tabular}{lcc}
\hline Praças & Área total $\left(\mathbf{m}^{2}\right)$ & Categoria * \\
\hline B1P1 & 450 & Parque de vizinhança \\
B1P2 & 400 & Parque de vizinhança \\
B1P3 & 750 & Parque de vizinhança \\
B1P4 & 1000 & Parque de vizinhança \\
B1P5 & 400 & Parque de vizinhança \\
B2P1 & 32000 & Parque de Bairro \\
B2P2 & 800 & Parque de vizinhança \\
B3P1 & 2700 & Parque de vizinhança \\
B3P2 & 242 & Parque de vizinhança \\
B4P1 & 594 & Parque de vizinhança \\
B4P2 & 4000 & Parque de vizinhança \\
B5P1 & 2250 & Parque de vizinhança \\
B5P2 & 10000 & Parque de bairro \\
B5P3 & 700 & Parque de vizinhança \\
B5P4 & 4000 & Parque de vizinhança \\
B5P5 & 6000 & Parque de vizinhança \\
B6P1 & 1700 & Parque de vizinhança \\
B6P2 & 540 & Parque de vizinhança \\
B6P3 & 1600 & Parque de vizinhança \\
B6P4 & 530 & Parque de vizinhança \\
B7P1 & 1250 & Parque de vizinhança \\
B8P1 & 29400 & Parque de bairro \\
\hline
\end{tabular}

* Segundo classificação de Jantzen citada por Cavalheiro \& Del Picchia (1992).

$\mathrm{Na}$ Tabela 17, observa-se a área total de parques de vizinhança e de bairro distribuídos nos diferentes bairros (B1 a B8) levantados. 
Tabela 17. Áreas das praças classificadas em parques de vizinhança e de bairro, nos diferentes bairros estudados na cidade de Vinhedo (SP), 2002.

\begin{tabular}{lccc}
\hline Bairro & $\begin{array}{c}\text { Parque de vizinhança } \\
\left(\mathbf{m}^{\mathbf{2}}\right)\end{array}$ & $\begin{array}{c}\text { Parque de bairro } \\
\left(\mathbf{m}^{\mathbf{2}}\right)\end{array}$ & $\begin{array}{c}\text { Área total } \\
\left(\mathbf{m}^{\mathbf{2}}\right)\end{array}$ \\
\hline B1 & 3000 & 0 & 3000 \\
B2 & 800 & 32000 & 32800 \\
B3 & 2942 & 0 & 2942 \\
B4 & 4594 & 0 & 4594 \\
B5 & 12950 & 10000 & 22950 \\
B6 & 4370 & 0 & 4370 \\
B7 & 1250 & 0 & 1250 \\
B8 & 0 & 29400 & 29400 \\
\hline
\end{tabular}

A cidade de Vinhedo (SP) apresentou $29.906 \mathrm{~m}^{2}$ de parque de vizinhança e $71.400 \mathrm{~m}^{2}$ de parque de bairro, totalizando $101.360 \mathrm{~m}^{2}$ de áreas verdes

Os bairros B2 e B7 apresentam quantidade pouco significativa de parques de vizinhança e B8 não apresenta nenhum parque de vizinhança.

\section{4 Índices calculados}

Por meio da soma média da área da copa de cada espécie, foi possível contabilizar a área de cobertura vegetal arbórea das praças da cidade de Vinhedo.

A área total de copa encontrada foi de $25.428,45 \mathrm{~m}^{2}$. Considerando que o município possui uma população de 46.174 habitantes urbanos, tem-se o índice calculado a seguir.

\subsection{1 Índice de cobertura vegetal (ICV)}

Para obtenção do ICV, foi utilizado o somatório das áreas de copa (Anexo E), dividido pelo número total de habitantes da área urbana.

$$
\mathrm{ICV}=\quad 25.428,45 \mathrm{~m}^{2} \text { de área das copa }
$$


$\mathrm{ICV}=0,55 \mathrm{~m}^{2}$ de copa / habitantes da área urbana

Milano et al. (1992b) obtiveram o índice de 3,06 $\mathrm{m}^{2} /$ habitante para arborização de ruas da cidade de Curitiba (PR).

As áreas dos canteiros sem arborização não foram consideradas.

\subsection{2 Índice de áreas verdes (IAV)}

\subsubsection{1 Índice de áreas verdes total (IAVT)}

IAVT $=\frac{101.306 \mathrm{~m}^{2} \text { de praça }}{46.174 \text { habitantes da área urbana }}$

$\mathrm{IAVT}=2,19 \mathrm{~m}^{2}$ de praça/habitante da área urbana

Milano et al. (1992c) encontraram o índice de áreas verdes representado pela arborização de rua de $2,88 \mathrm{~m}^{2} /$ habitante e de $2,09 \mathrm{~m}^{2} /$ habitante de cobertura vegetal de áreas verdes públicas, para a cidade de Vitória (ES). Os autores comentaram que o índice para arborização de rua poderia crescer significativamente com o gradativo desenvolvimento das árvores, o que leva a crer que esse índice, provavelmente, seria mais adequado se considerado como índice de cobertura vegetal. Os autores também citaram o índice de $13,93 \mathrm{~m}^{2} /$ habitante para a cidade de Maringá (PR), índice este que estaria o mais próximo do recomendado pela Sociedade Brasileira de Arborização Urbana, ou seja de $15 \mathrm{~m}^{2} /$ habitante (Sociedade Brasileira de Arborização Urbana, 1996).

Carvalho (2001) comentou que, em Lavras (MG), o índice de áreas verdes indicou a existência de $0,34 \mathrm{~m}^{2} /$ habitante e Lima et al. (1990) encontraram o valor de 2,2 $\mathrm{m}^{2} /$ habitante para a cidade de Piracicaba (SP), sendo que o valor encontrado em Vinhedo está acima do de Lavras e praticamente igual ao de Piracicaba.

Segundo Macedo et al. (1997), em trabalho realizado em 291 municípios, foi possível obter, pela soma das áreas de praças e parques públicos das cidades envolvidas, 
um índice médio de $1,198 \mathrm{~m}^{2}$ de área verde para cada município estudado. Considerando esse índice médio, a cidade de Vinhedo apresenta índice duas vezes maior. Vale ressaltar que os parques públicos não foram computados.

Pode-se observar que o índice de Vinhedo está muito aquém do mínimo de $15 \mathrm{~m}^{2} /$ habitante para áreas verdes públicas destinadas a recreação, sugerido pela Sociedade Brasileira de Arborização Urbana (1996).

\subsubsection{2 Índice de áreas verdes para parque de vizinhança (IAVPV)}

$$
\mathrm{IAVPV}=29.906 \mathrm{~m}^{2} \text { de parque de vizinhança }
$$

46.174 habitantes da área urbana

$\mathrm{IAVPV}=0,65 \mathrm{~m}^{2}$ de parque de vizinhança /habitante da área urbana

Lima et al. (1990) encontraram o valor de $0,54 \mathrm{~m}^{2} / \mathrm{habitante}$ em Piracicaba (SP) e Sousa et al. (1992), o valor de $1,96 \mathrm{~m}^{2} /$ habitante em Botucatu (SP) para parque de vizinhança. Carvalho (2001) encontrou o valor de $0,12 \mathrm{~m}^{2} /$ habitante para parques de vizinhança em Lavras (MG). Vinhedo (SP) apresentou um índice aquém do da cidade de Botucatu .

\subsubsection{3 Índice de áreas verdes para parque de bairro (IAVPB)}

$\mathrm{IAVPB}=71.400 \mathrm{~m}^{2}$ de parques de vizinhança 46.174 habitantes da área urbana

$\mathrm{IAVPB}=1,55 \mathrm{~m}^{2}$ de parque de bairro/habitante da área urbana

Lima et al. (1990) encontraram o valor de $0,60 \mathrm{~m}^{2} /$ habitante em Piracicaba, e Sousa et al. (1992), o valor de $0,77 \mathrm{~m}^{2} /$ habitante em Botucatu para parque de bairro. Carvalho (2001) encontrou $0,19 \mathrm{~m}^{2} /$ habitante para parque de bairro em Lavras. Vinhedo (SP) apresentou um índice bem superior aos das três cidades. 


\subsection{3 Índice de áreas verdes utilizáveis (IAVU)}

O cálculo do índice de áreas verdes utilizáveis foi feito por meio do somatório das áreas totais das praças que apresentaram índice bom e razoável quanto ao estado de conservação de elementos naturais e construídos, dividido pelo número de habitantes residentes no perímetro urbano.

Por observação in loco, pode-se afirmar que estas áreas são efetivamente utilizadas pela população. São estas as seguintes áreas: B1P1, B1P2, B1P4, B2P1, B4P1, B4P2, B5P1, B5P2, B5P3, B5P4, B6P1, B6P2, B6P3, B7P1 e B8P1.

$$
\text { IAVU }=\frac{89.884 \mathrm{~m}^{2} \text { de praças em bom estado }}{46.174 \text { habitantes da área urbana }}
$$

IAVU $=1,95 \mathrm{~m}^{2}$ de praças utilizáveis/habitante da área urbana

\subsection{4 Índice de área verde por bairro (IAVB)}

Como não foi possível obter dados numéricos sobre a população de cada bairro, optou-se por calcular o índice de área verde por bairro, por meio da quantidade de praças por bairro e a área de cada bairro, como pode ser observado na Tabela 18.

Tabela 18. Índice de área verde por bairro obtido nas praças dos diferentes bairros da cidade de Vinhedo (SP), 2002

\begin{tabular}{lccc}
\hline Bairro & Área das praças $\left(\mathbf{m}^{\mathbf{2}}\right)$ & Área do bairro $\left(\mathbf{m}^{\mathbf{2}}\right)$ & IAVB $\left.\mathbf{( m}^{\mathbf{2}}\right)$ \\
\hline B1 & 3000 & 800000 & 0,0038 \\
B2 & 32800 & 765000 & 0,0429 \\
B3 & 2942 & 750000 & 0,0039 \\
B4 & 4594 & 302500 & 0,0152 \\
B5 & 22950 & 300000 & 0,0765 \\
B6 & 4370 & 490000 & 0,0089 \\
B7 & 1250 & 906250 & 0,0014 \\
B8 & 29400 & 2718750 & 0,0108 \\
\hline
\end{tabular}


Os bairros B2, B4 e B5 apresentaram os maiores índices de área verde por bairro, sendo que estes bairros possuíam vegetação consolidada. Os bairros B1, B3 e B7 apresentaram índices muito pequenos, tendendo a zero.

Vinhedo apresentou índice de $0,1633 \mathrm{~m}^{2}$ de área verde por bairro.

\subsection{Setorização de bairros}

Dos oito bairros levantados, apenas os bairro João XXIII (B1) e Santa Rosa encontraram-se no setor S3, ou seja, área mista onde coexistem residências, comércio e serviços; os bairros Aquário (B2), Vila Planalto (B4) e Centro (B5) estavam localizados em S2, região residencial, próxima ao centro, ou localizadas em bairros onde há apenas comércio local, e os bairros Jardim Três Irmãos (B6), Jardim Von Zuben (B7) e Capela (B8) estavam em S4, ou seja, em áreas predominantemente industriais, com poucas residências, em sua maioria de baixo padrão.

Os bairros levantados foram distribuídos conforme a sua localização dentro da setorização (Anexo D), indicando a quantidade de praças e a área de cobertura vegetal arbórea, por bairro, conforme demonstra a Tabela 19:

Tabela 19. Localização dos bairros dentro da setorização, indicando a quantidade de praças e sua área de cobertura vegetal arbórea, na cidade de Vinhedo (SP), 2002.

\begin{tabular}{llcc}
\hline Setorização & Bairro & Praças por bairro (\%) & Cobertura vegetal $\left(\mathbf{m}^{\mathbf{2}}\right)$ \\
\hline S2 & B2, B4 e B5 & 40,91 & $19.466,04$ \\
S3 & B1 e B3 & 31,82 & $4.336,15$ \\
S4 & B6, B7 e B8 & 27,27 & $1.626,26$ \\
\hline
\end{tabular}

A Tabela 19 mostra que os bairros localizados em S2 possuíam maior percentagem de praças $(40,91 \%)$ e de cobertura vegetal $\left(19.466,04 \mathrm{~m}^{2}\right)$. Esses bairros apresentaram arborização superior aos de outros setores, principalmente em relação aos localizados em áreas predominantemente industriais, com poucas residências, em sua 
maioria de baixo padrão, como é o caso de S4. Os setores S2 e S3 apresentaram quantidade de praças e área de cobertura vegetal superiores, em relação a S4.

\subsection{Correlação entre o nível sócio-econômico do bairro e a arborização de praças}

De acordo com o Decreto n 149 da Prefeitura Municipal de Vinhedo, analisouse, por bairro, a correlação entre a quantidade de praças, a quantidade total de árvores, a área de cobertura vegetal arbórea existente nas praça e o custo médio do metro quadrado $\left(\mathrm{m}^{2}\right)$ do terreno, conforme a Tabela 20.

Pode-se confirmar, observando a Tabela 20, que, apesar de a frequiência do número de praças ser igual nos Bairros B1 e B5, a cobertura vegetal foi quase dez vezes maior em B5 e o valor da metragem de terreno foi quase três vezes superior.

Tabela 20. Correlação por bairro da frequiência de praças, freqüência total de árvores, área de cobertura vegetal arbórea existente nas praças e custo médio do metro quadrado de terreno, na cidade de Vinhedo (SP), 2002.

\begin{tabular}{lcccc}
\hline Bairro & $\begin{array}{c}\text { Freqüiência de } \\
\text { praças }(\boldsymbol{\%})\end{array}$ & $\begin{array}{c}\text { Freqüiência de } \\
\text { árvores }(\boldsymbol{\%})\end{array}$ & Cobertura vegetal $\mathbf{( m}^{\mathbf{2})}$ & $\begin{array}{c}\text { Valor médio do } \\
\text { terreno }(\mathbf{R} \mathbf{\text { /m}} \mathbf{2})\end{array}$ \\
\hline B1 & 22,73 & 9,42 & 1050,37 & 27,86 \\
B2 & 9,09 & 25,65 & 6597,51 & 69,13 \\
B3 & 9,09 & 6,54 & 3285,78 & 47,16 \\
B4 & 9,09 & 5,89 & 2208,51 & 79,32 \\
B5 & 22,73 & 43,85 & 10660,02 & 86,82 \\
B6 & 18,18 & 4,19 & 1036,04 & 28,40 \\
B7 & 4,55 & 0,39 & 11,78 & 27,33 \\
B8 & 4,55 & 4,06 & 578,44 & 25,18 \\
\hline
\end{tabular}

Os bairros B2 e B5 apresentaram o maior valor da metragem de terreno e a maior cobertura vegetal. Em B4, houve baixa frequiência de árvores, o que é explicado pelo número reduzido de praças, somente duas; mesmo assim, o bairro apresentou a quarta área de cobertura vegetal. Os três são bairros de populações com nível sócio econômico de médio a alto. 
O bairro B1 apresentou baixa cobertura vegetal. Já B3 apresentou boa cobertura vegetal, mas precisava de intervenção urgente na praça $\mathrm{B} 3 \mathrm{P} 1$. O valor da metragem de B3 é mais alto que B1, pois B3 está localizado próximo ao centro. A população residente nos dois bairros é de nível sócio-econômico médio a baixo.

Os bairros B6, B7 e B8 apresentam população de baixa renda, o que foi possível constatar pelo valor da metragem do terreno e pela a localização dos três em S4. Os bairros B7 e B8 possuíam exemplares jovens de árvores, mostrando que estas áreas foram arborizadas recentemente.

Através da Planta de Valores Imobiliários pode-se observar que os terrenos localizados no entorno da praça $\mathrm{B} 5 \mathrm{P} 1$, foram os de maior valor por metro quadrado $\left(\mathrm{m}^{2}\right)$, sendo que este valor vai diminuindo a medida que os terrenos vão se distanciado desta praça. O mesmo foi verificado em relação a praça B4P2.

Foi possível observar que a arborização está diretamente ligada ao valor do imóvel e, consequentemente, ao poder aquisitivo da população. As praças com melhor situação estavam localizadas em bairros de nível sócio-econômico mais alto. 


\section{CONCLUSÕES}

Com base no levantamento realizado nas vinte e duas praças da cidade de Vinhedo (SP) e na análise dos resultados obtidos, pode-se chegar às conclusões que seguem.

a) Vinhedo apresenta carência de praças em muitos bairros, pois, dos 31 existentes apenas oito possuem alguma área destinada a praças.

b) Há boa diversificação de espécies no geral, porém ocorre concentração de uma mesma espécie em determinados bairros.

c) Há predominância de espécies arbóreas nativas, porém nenhuma das espécies encontradas tem ocorrência natural no cerrado, fisionomia típica do município de Vinhedo (SP).

d) A maioria dos indivíduos apresenta quase todas as características naturais da espécie mantidas, mostrando que as técnicas culturais utilizadas, principalmente em relação ao tipo e período de poda, são adequadas.

e) Existe nas praças um número muito pequeno de árvores que sofreram injúrias mecânicas graves ou que apresentaram alto nível de infestação de pragas, doenças ou parasitas.

f) Apenas cinco praças apresentaram situação boa de conservação dos elementos naturais e construídos.

g) Os bairros B1, B2, B3, B4 e B5 apresentaram áreas consolidadas quanto à vegetação arbórea, pois apresentaram indivíduos com altura superior a 6m e CAP acima de $50 \mathrm{~cm}$.

h) Os bairros localizados no setor S2 apresentaram arborização superior aos demais setores, principalmente em relação aos localizados em áreas predominantemente 
industriais, com poucas residências, em sua maioria de baixo padrão, como é o caso de S4.

i) A pouca variação entre os índices IAV $=2,19 \mathrm{~m}^{2}$ e o IAVU $=1,95 \mathrm{~m}^{2}$ indica que a maioria das áreas verdes é utilizável.

j) Bairros com o mesmo número de parças, caso de B1 e B5, diferiram em relação à cobertura vegetal e ao valor do terreno, maiores em B5.

k) Os bairros dos setores $\mathrm{S} 2$, de maior valor territorial, apresentaram índice de áreas verdes por bairro superiores aos de menor valor territorial.

1) As praças com melhor situação de limpeza e de elementos naturais e construídos estavam localizadas em bairros de maior valor territorial.

m) A presença de equipamentos e construções não garante a freqüência da população, como ocorre na praça B7P1 que, apesar de possuir "playground", não é utilizada pelo público.

Seguem abaixo algumas recomendações para melhor conservação das praças existentes e para o planejamento de áreas futuras.

a) Evitar o predomínio de espécies que apresentem pequena área de sombra, como Syagrus romanzoffiana (jerivá), optando-se por espécies que forneçam área maior de sombra, procurando manter ou ampliar a diversidade de espécies.

b) Incentivar o plantio de espécies nativas do município de Vinhedo, passando a priorizar espécies endêmicas da região, com o objetivo de contribuir para sua conservação.

c) Manter os procedimentos de podas de condução, evitando-se as podas drásticas. Não é necessário que sejam feitas podas de condução em espécies arbóreas que não estejam em áreas destinadas ao tráfego de pedestres.

d) Executar o monitoramento periódico que permita a avaliação de aspectos qualiquantitativos a partir das características das árvores e seus respectivos locais de plantio, para que estas informações sirvam de instrumento tanto para o planejamento de novos plantios como para a adequação de práticas de manejo. 
e) Implantar programas de educação ambiental.

f) Estimular a população do entorno das praças existentes e futuras a se envolver no processo de implantação e manutenção, porém sob orientação técnica da Prefeitura Municipal.

g) Implantar cursos de treinamento em jardinagem, para qualificar a população que, em alguns casos, já é responsável pela manutenção de algumas áreas. 
ANEXOS 
Anexo A - Formulário para caracterização das praças da cidade de Vinhedo (SP), 2002.

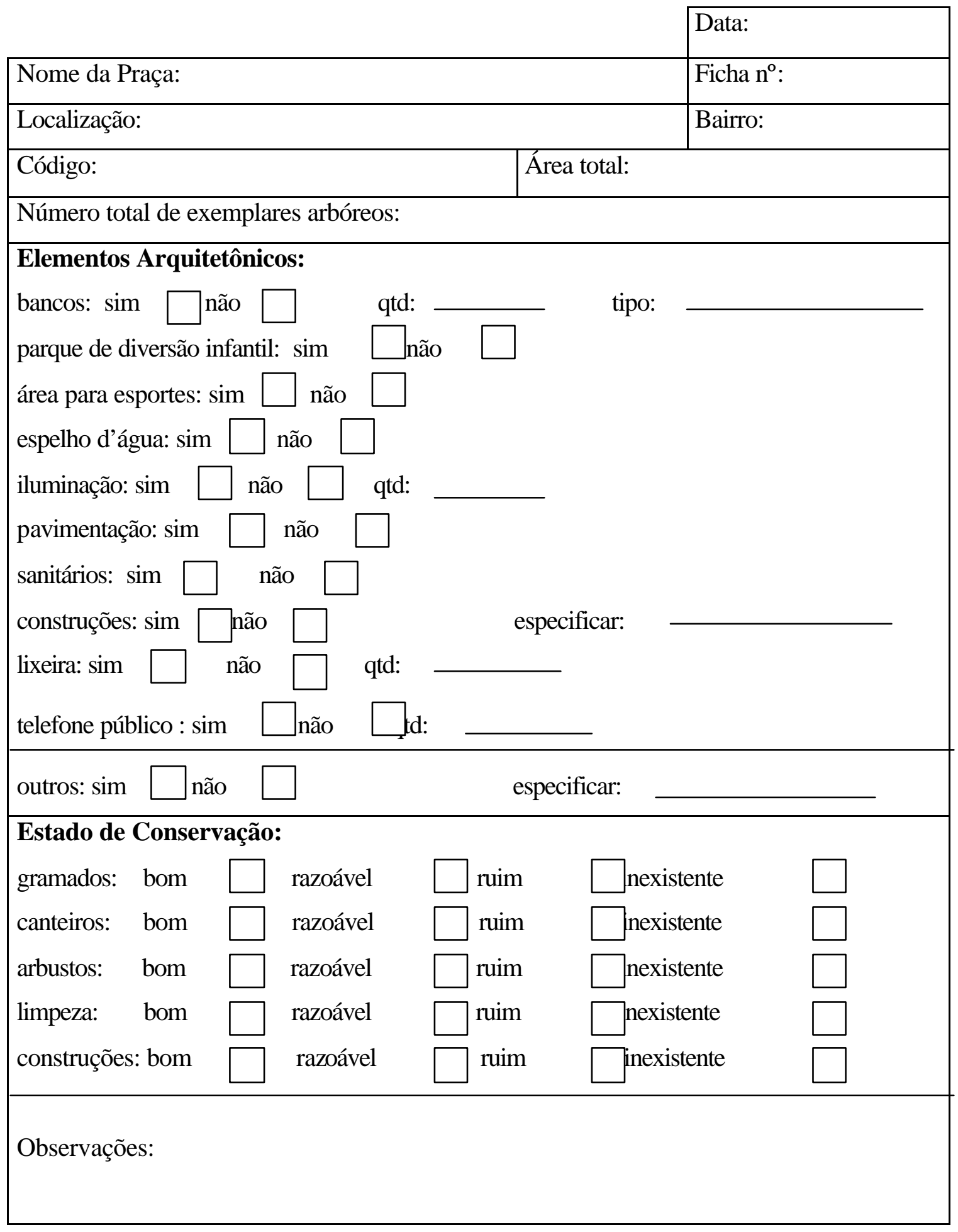


Anexo B - Formulário para caracterização dos indivíduos arbóreos das praças da cidade de Vinhedo (SP), 2002.

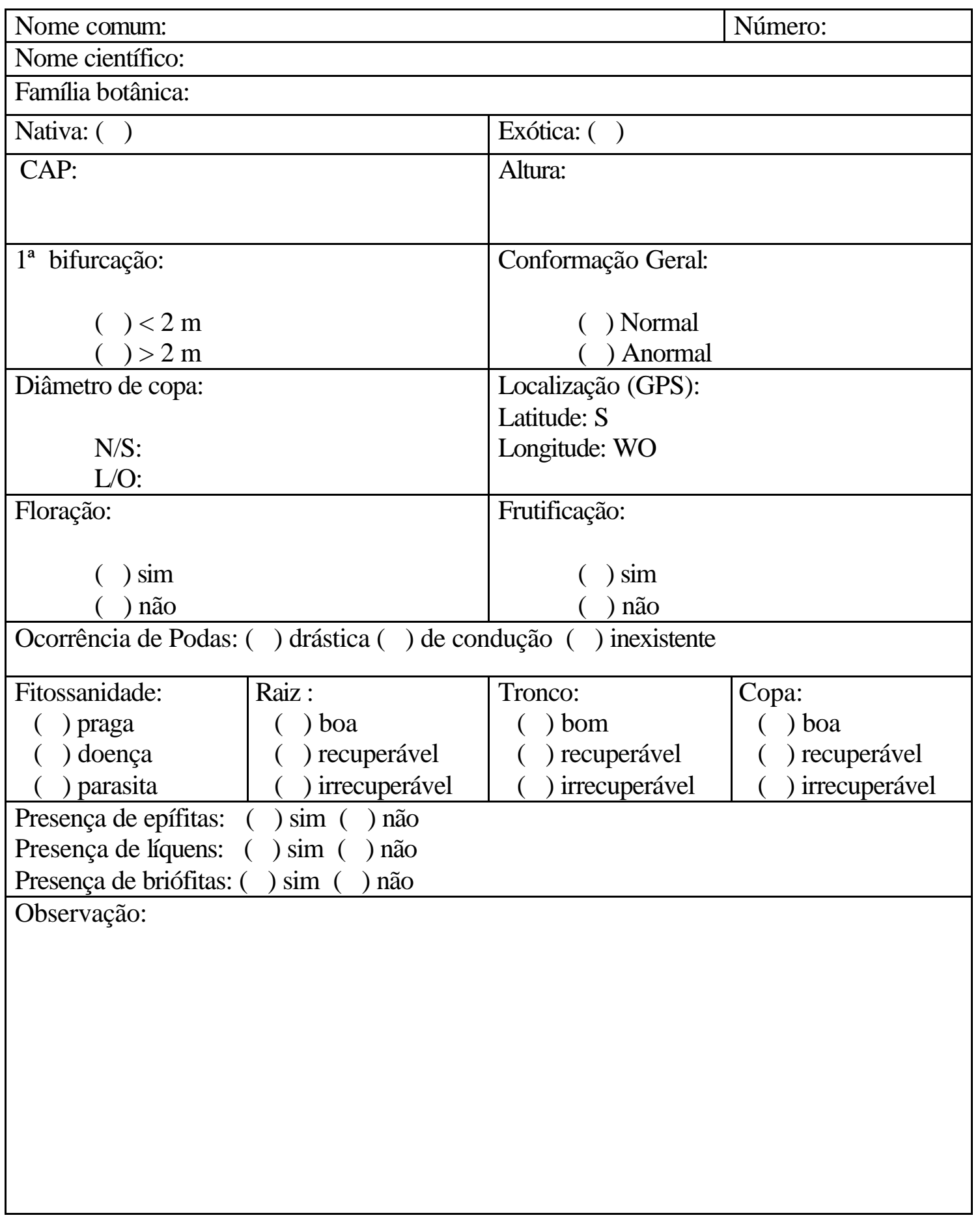


Anexo C - Localização de plantas não identificadas, contendo o CAP, altura $(\mathrm{H})$ e diâmetro médio da copa, na cidade de Vinhedo, 2002.

\begin{tabular}{|c|c|c|c|c|c|}
\hline \multirow{2}{*}{$\begin{array}{l}\text { Praça } \\
\text { B2P1 }\end{array}$} & \multicolumn{2}{|c|}{$\begin{array}{l}\text { Localização } \\
\text { (Coordenadas) }\end{array}$} & \multirow{2}{*}{$\begin{array}{c}\text { CAP (m) } \\
0,10\end{array}$} & \multirow{2}{*}{$\begin{array}{l}\mathrm{h}(\mathrm{m}) \\
2,20\end{array}$} & \multirow{2}{*}{$\begin{array}{c}\text { Diâmetro médio de } \\
\text { copa }(\mathrm{m})\end{array}$} \\
\hline & S 23ㅇ 01'29.8" & WO 46 58' 58.2" & & & \\
\hline B2P1 & $\mathrm{S} 23^{\circ} 01^{\prime} 37.7^{\prime \prime}$ & WO 46 59' $04.0^{\prime \prime}$ & 0,15 & 2,30 & 4,05 \\
\hline B5P2 & $\mathrm{S} 23^{\circ} 01^{\prime} 53.9^{\prime \prime}$ & WO 46 $58^{\prime} 30.8^{\prime \prime}$ & 0,25 & 2,50 & 2,50 \\
\hline B5P2 & $\mathrm{S} 23^{\circ} 01^{\prime} 53.8^{\prime \prime}$ & WO 46 $58^{\prime} 30.9^{\prime \prime}$ & 0,30 & 2,50 & 3,30 \\
\hline B5P2 & $\mathrm{S} 23^{\circ} 01^{\prime} 55.9^{\prime \prime}$ & WO 46 $58^{\prime} 30.0^{\prime \prime}$ & 0,40 & 10,00 & 3,85 \\
\hline B5P2 & S $23^{\circ} 01^{\prime} 56.9^{\prime \prime}$ & WO 46 $58^{\prime} 31.6^{\prime \prime}$ & 0,65 & 8,00 & 6,50 \\
\hline $\mathrm{B} 5 \mathrm{P} 2$ & $\mathrm{~S} 23^{\circ} 01^{\prime} 56.7^{\prime \prime}$ & WO $46^{\circ} 58^{\prime} 31.8^{\prime \prime}$ & 0,80 & 8,50 & 6,50 \\
\hline B5P3 & S $23^{\circ} 01^{\prime} 57.4^{\prime \prime}$ & WO 46 $58^{\prime} 41.0^{\prime \prime}$ & 1,70 & 12,10 & 12,55 \\
\hline B6P1 & $\mathrm{S} 23^{\circ} 00^{\prime} 51.5^{\prime \prime}$ & WO 46 59' 29.2" & 0,90 & 7,90 & 9,35 \\
\hline B6P1 & $\mathrm{S} 23^{\circ} 00^{\prime} 51.7^{\prime \prime}$ & WO 46 59' 29.9" & 0,10 & 2,00 & 2,20 \\
\hline B6P1 & S $23^{\circ} 00^{\prime} 51.7^{\prime \prime}$ & WO 46 $59^{\prime} 29.8^{\prime \prime}$ & 0,25 & 3,20 & 3,70 \\
\hline B6P1 & $\mathrm{S} 23^{\circ} 00^{\prime} 51.5^{\prime \prime}$ & WO 46 $59^{\prime} 29.8^{\prime \prime}$ & 0,20 & 2,50 & 3,10 \\
\hline B6P1 & $\mathrm{S} 23^{\circ} 00^{\prime} 51.1^{\prime \prime}$ & WO 46 59' $29.8^{\prime \prime}$ & 0,25 & 3,00 & 2,95 \\
\hline B6P1 & $\mathrm{S} 23^{\circ} 00^{\prime} 51.1^{\prime \prime}$ & WO 46 59'30.2" & 0,25 & 3,00 & 4,25 \\
\hline B6P1 & $\mathrm{S} 23^{\circ} 00^{\prime} 51.1^{\prime \prime}$ & WO 46 $59^{\prime} 30.3^{\prime \prime}$ & 0,75 & 5,70 & 3,80 \\
\hline B6P1 & $\mathrm{S} 23^{\circ} 00^{\prime} 51.1^{\prime \prime}$ & WO 46 59' $30.5^{\prime \prime}$ & 0,15 & 3,50 & 3,60 \\
\hline B6P1 & $\mathrm{S} 23^{\circ} 00^{\prime} 51.0^{\prime \prime}$ & WO 46 59' $30.5^{\prime \prime}$ & 0,45 & 3,50 & 3,45 \\
\hline B6P1 & $\mathrm{S} 23^{\circ} 00^{\prime} 50.0^{\prime \prime}$ & WO 46 59' $30.4^{\prime \prime}$ & 0,85 & 7,10 & 8,80 \\
\hline B6P1 & $\mathrm{S} 23^{\circ} 00^{\prime} 50.0^{\prime \prime}$ & WO 46 59' $30.3^{\prime \prime}$ & 0,70 & 7,50 & 7,55 \\
\hline B6P1 & $\mathrm{S} 23^{\circ} 00^{\prime} 50.1^{\prime \prime}$ & WO 46 59' 29.6" & 0,25 & 2,60 & 3,85 \\
\hline B6P1 & $\mathrm{S} 23^{\circ} 00^{\prime} 50.5^{\prime \prime}$ & WO 46 59' 29.5" & 0,20 & 2,30 & 4,10 \\
\hline B6P2 & $\mathrm{S} 23^{\circ} 01^{\prime} 01.0^{\prime \prime}$ & WO 46 $59^{\prime} 28.5^{\prime \prime}$ & 0,45 & 4,80 & 6,95 \\
\hline $\mathrm{B} 2 \mathrm{P} 1$ & $\mathrm{~S} 23^{\circ} 01^{\prime} 35.1 "$ & WO 46 59' 01.3" & 0,25 & 3,10 & 3,30 \\
\hline B3P1 & $\mathrm{S} 23^{\circ} 01^{\prime} 46.4^{\prime \prime}$ & WO $46^{\circ} 58^{\prime} 59.5^{\prime \prime}$ & 0,25 & 3,50 & 3,35 \\
\hline B4P1 & S $23^{\circ} 01^{\prime} 54.7^{\prime \prime}$ & WO $46^{\circ} 58^{\prime} 13.1^{\prime \prime}$ & 0,55 & 7,20 & 5,80 \\
\hline B4P2 & $\mathrm{S} 23^{\circ} 01^{\prime} 57,9^{\prime \prime}$ & WO 46 $58^{\prime} 14,7^{\prime \prime}$ & 2,70 & 9,50 & 15,95 \\
\hline B4P2 & S $23^{\circ} 01^{\prime} 57.9^{\prime \prime}$ & WO 46' $58^{\prime} 14.5^{\prime \prime}$ & 1,95 & 10,50 & 14,00 \\
\hline B4P2 & $\mathrm{S} 23^{\circ} 01^{\prime} 58.0^{\prime \prime}$ & WO 46 $58^{\prime} 14.3^{\prime \prime}$ & 2,20 & 9,50 & 16,85 \\
\hline $\mathrm{B} 4 \mathrm{P} 2$ & S $23^{\circ} 01^{\prime} 57.4^{\prime \prime}$ & WO 46 $58^{\circ} 13.3^{\prime \prime}$ & 0,10 & 2,50 & 3,95 \\
\hline B5P1 & $\mathrm{S} 23^{\circ} 01^{\prime} 46.5^{\prime \prime}$ & WO 46 $58^{\prime} 29.1^{\prime \prime}$ & 0,50 & 9,10 & 6,20 \\
\hline B5P2 & S $23^{\circ} 01^{\prime} 54.3^{\prime \prime}$ & WO 46 $58^{\prime} 32.9^{\prime \prime}$ & 0,35 & 7,00 & 4,20 \\
\hline B5P2 & S $23^{\circ} 01^{\prime} 54.6^{\prime \prime}$ & WO 46 $58^{\prime} 32.9^{\prime \prime}$ & 0,75 & 11,00 & 7,40 \\
\hline
\end{tabular}


Planta de setorização e de estado de consolidação da vegetação arbórea.

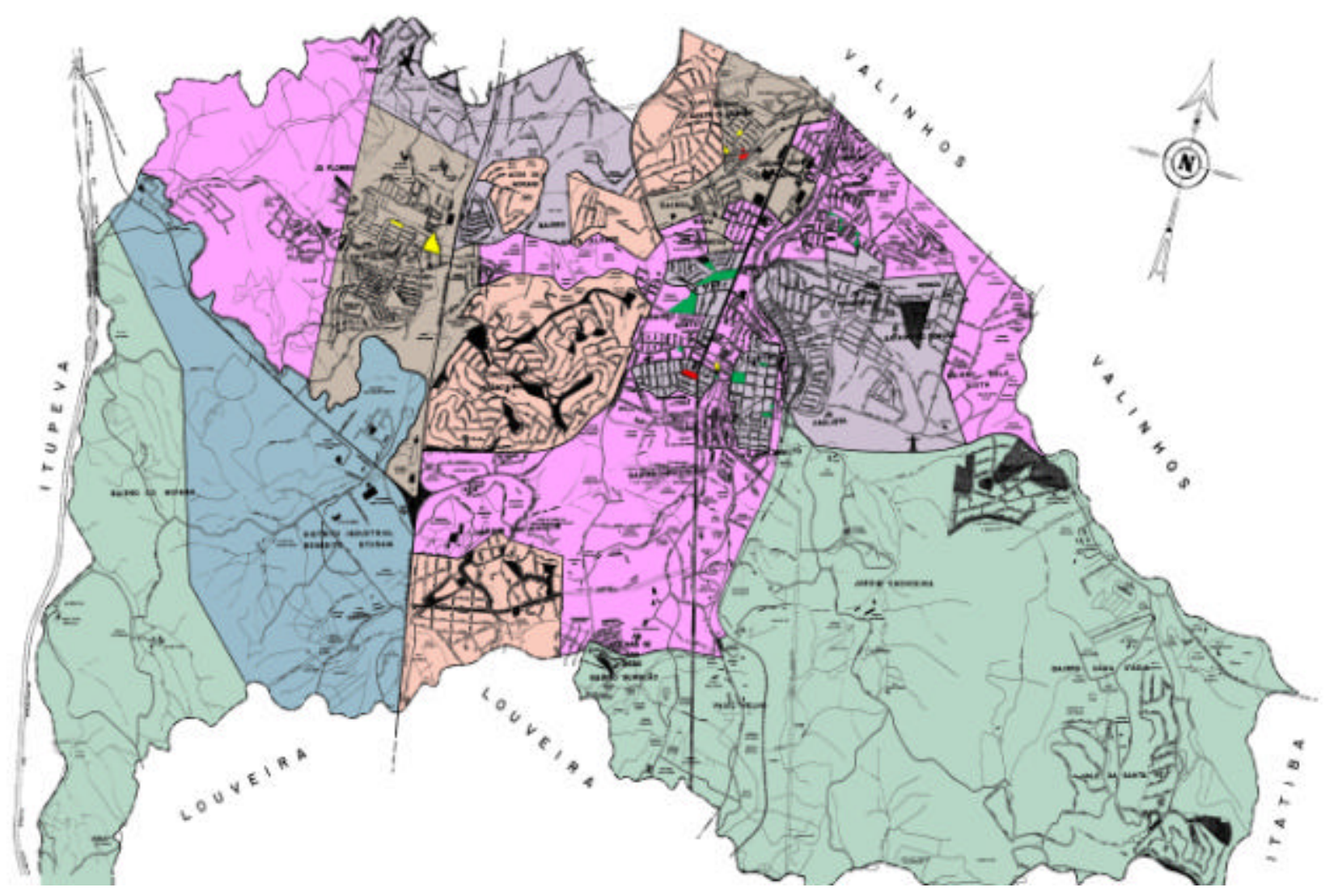

\section{Setorização}

Estritamente residencial

Residencial

Misto (Residencial/Comercial/Serviços)

Predominante industrial

Industrial

Preservação de manancial

Estado de conservação da vegetação arbórea

Consolidada

Em consolidação

Não consolidada 


\section{REFERÊNCIAS BIBLIOGRÁFICAS}

ANDRADE, T.O. de. Inventário e análise da arborização viária da estância turística de Campos do Jordão, SP. Piracicaba, 2002. 112p. Dissertação (Mestrado) Escola Superior de Agricultura “Luiz de Queiroz”, Universidade de São Paulo.

BARBOSA, L.M; MARTINS, S.E.; MATIOLLI, D.S.; BARBOSA, K.C. Conceitos e sugestões para conservação da diversidade biológica em áreas urbanas. Caderno UniABC Ciências Biológicas, v.3, n. 7, p.44-62, mar. 2001.

BATISTA, J.L.F. Mensuração de árvores: uma introdução à dendrometria. Piracicaba: ESALQ, Departamento de Ciências Florestais, s.d. 77p.

BIANCHI, C.G.; GRAZIANO, T.T. Caracterização e análise das áreas verdes urbanas de Jaboticabal - SP. In: CONGRESSO BRASILEIRO SOBRE ARBORIZAÇÃO URBANA, 1; ENCONTRO NACIONAL SOBRE ARBORIZAÇÃO URBANA, 4., Vitória, 1992. Anais. Vitória: Prefeitura, 1992. v.2, p. 225-237.

BIONDI, D.; BATISTA, A.C.; FERREIRA, R.L.C. Plano de arborização para o bairro de Brasília Teimosa - Recife - PE. In: ENCONTRO NACIONAL SOBRE ARBORIZAÇÃO URBANA, 3., Curitiba, 1990. Anais. Curitiba: FUPEF do Paraná, 1990. p. 211-219.

BRAGA, M.A. Evolução dos jardins. s.n.t. 37p.

BUSARELLO, O. Planejamento urbano e arborização In: ENCONTRO NACIONAL SOBRE ARBORIZAÇÃO URBANA, 3., Curitiba, 1990. Anais. Curitiba: FUPEF do Paraná, 1990. p.54-59. 
CARVALHO, L.M de. Áreas verdes da cidade de Lavras/MG: caracterização, usos e necessidades. Lavras, 2001. 115 p. Dissertação (Mestrado) - Universidade Federal de Lavras.

CAVALHEIRO, F. Arborização urbana: planejamento, implantação e condução. In: CONGRESSO BRASILEIRO DE ARBORIZAÇÃO URBANA, 2; ENCONTRO NACIONAL SOBRE ARBORIZAÇÃO URBANA, 5., São Luís, 1994. Anais. São Luís: Sociedade Brasileira de Arborização Urbana, 1994. p. $227-231$.

CAVALHEIRO, F.; DEL PICCHIA, P.C.D. Áreas verdes: conceitos, objetivos e diretrizes para o planejamento. In: CONGRESSO BRASILEIRO SOBRE ARBORIZAÇÃO URBANA, 1.; ENCONTRO NACIONAL SOBRE ARBORIZAÇÃO URBANA, 4., Vitória, 1992. Anais. Vitória: Prefeitura, 1992. v.1, p. 29-37.

CAVALHEIRO, F; NUCCI, J.C. Espaços livres e qualidade de vida urbana. Paisagem Ambiente Ensaios, n.11, p. 279-288, dez. 1998.

CHIMENTI, B.N. Componentes básicos para projetos de espaços livres de uso público. In: ENCONTRO NACIONAL SOBRE ARBORIZAÇÃO URBANA, 6., Brasília, 6., (compact disc). 2001. Anais. Brasília: s. ed., 2001.

COSTA, L.A da; HIGUCHI, N. Arborização de ruas de Manaus: avaliação qualitativa e quantitativa. Revista Árvore, v.23, n.2, p.223-232, 1999.

DEMATTÊ, M.E.S.P. Princípios de paisagismo. Jaboticabal: Funep, 1997. 104p.

DETZEL, V.A. Avaliação monetária de árvores urbanas. In: ENCONTRO NACIONAL SOBRE ARBORIZAÇÃO URBANA, 3., Curitiba, 1990. Anais. Curitiba: FUPEF do Paraná, 1990. p. 140-152

DETZEL, V.A. Arborização urbana: importância e avaliação econômica. In: CONGRESSO BRASILEIRO SOBRE ARBORIZAÇÃO URBANA, 1.; ENCONTRO NACIONAL SOBRE ARBORIZAÇÃO URBANA, 4., Vitória, 1992. Anais. Vitória: Prefeitura, 1992. v.1, p. 39-52. 
FELICIANO, A.L.P.; BEZERRA, I.F.F.; CARVALHO, M. de F. de A.; MEUNIER, I.M.J.; LIMA, A.G.V. de; NASCIMENTO, L.M. do. Uso de espécies arbóreas da Mata Atlântica na arborização da cidade de Recife. In: CONGRESSO BRASILEIRO SOBRE ARBORIZAÇÃO URBANA, 1.; ENCONTRO NACIONAL SOBRE ARBORIZAÇÃO URBANA, 4., Vitória, 1992. Anais. Vitória: Prefeitura, 1992. v.2, p. 379-387.

GEISER, R.R.; OLIVEIRA, M.C. de; BRUCK, E.C.; SANTOS, J.B. dos. Implantação de áreas verdes em grandes cidades. São Paulo: Escola Paulista de Arte e Decoração, 1976. 1v.

GONÇALVES, W. Florestas urbanas. Ação Ambiental, v.2, n.9, p. 17-19, dez. 1999/jan. 2000.

GOYA, C.R. Levantamento sistemático das áreas públicas livres de edificação \& e padrões de urbanização na cidade de Bauru. In: ENCONTRO NACIONAL SOBRE ARBORIZAÇÃO URBANA, 3., Curitiba, 1990. Anais. Curitiba: FUPEF do Paraná, 1990. p. 188-196.

GOYA, C.R. Relato histórico da arborização na cidade de São Paulo. In: CONGRESSO BRASILEIRO SOBRE ARBORIZAÇÃO URBANA, 1; ENCONTRO NACIONAL SOBRE ARBORIZAÇÃO URBANA, 4., Vitória, 1992. Anais. Vitória: Prefeitura, 1992. v.2, p. 403-408.

GREY, G.W.; DENEKE, F.J. Urban forestry. New York: John Wiley, 1978. 279 p.

GRIFFITH, J.J.; SILVA, S.M.F. da. Mitos e métodos no planejamento de sistemas de áreas verdes. In: ENCONTRO NACIONAL SOBRE ARBORIZAÇÃO URBANA, Maringá, 1987. Anais. Maringá: Prefeitura, 1987. p. 34-42.

HOEHNE, F.C. Arborização urbana. In: INSTITUTO DE BOTÂNICA. Relatório anual. São Paulo: Secretaria da Agricultura, Indústria e Comércio, 1944. p. $56-104$.

INSTITUTO BRASILEIRO DE GEOGRAFIA E ESTATÍSTICA. http://www.ibge.gov.br (31de mar. de 2002). 
KIRCHNER,F.F.; DETZEL,V.A.; MITISHITA, E.A. Mapeamento da vegetação urbana. In: ENCONTRO NACIONAL SOBRE ARBORIZAÇÃO URBANA, 3., Curitiba, 1990. Anais. Curitiba: FUPEF do Paraná; UFPR. 1990. p. 72-86.

LAPOIX, F. Cidades verdes e abertas. In: ENCICLOPÉDIA de ecologia. São Paulo: EDUSP, 1979. p. 324336.

LIMA, A.M.L.P.; CAVAlHEIRO, F.; CAMPOS, S.A.; MALÉSSIO, K.V.B. As áreas verdes de Piracicaba. In: ENCONTRO NACIONAL SOBRE ARBORIZAÇÃO URBANA, 3. Curitiba, 1990. Anais. Curitiba: FUPEF do Paraná, 1990. p. 181-187.

LIMA, A.M.L.P.; CAVALHEIRO, F.; NUCCI, J.C.; SOUSA, M.A.deL.B.; FIALHO, N.de.O.; DEL PICCHIA, P.C.D. Problemas de utilização na conceituação de termos como espaços livres, áreas verdes e correlatos. In: CONGRESSO BRASILEIRO DE ARBORIZAÇÃO URBANA, 2; ENCONTRO NACIONAL SOBRE ARBORIZAÇÃO URBANA, 5., São Luís, 1994. Anais. São Luís: Sociedade Brasileira de Arborização Urbana, 1994. p. 539-553.

LONGHI, S.J.; TEIXEIRA, I.F.; SANTOS, N.R.Z. dos. Caracterização qualitativa das áreas de lazer públicas de Veranópolis (RS). In: ENCONTRO NACIONAL SOBRE ARBORIZAÇÃO URBANA, 6.,Brasília (compact disc). 2001. Anais. Brasília: s. ed., 2001.

LORENZI, H. Árvores brasileiras: manual de identificação e cultivo de plantas arbóreas nativas do Brasil. Nova Odessa: Editora Plantarum, 1992. 352 p.

LORENZI, H. Árvores brasileiras: manual de identificação e cultivo de plantas arbóreas nativas do Brasil. 2.ed. Nova Odessa: Editora Plantarum, 1998. 352 p.

LORUSSO, D.C. S. Arborização urbana - medidas legais e fiscais - ocaso de Curitiba. In: ENCONTRO NACIONAL SOBRE ARBORIZAÇÃO URBANA, 3., Curitiba, 1990. Anais. Curitiba: FUPEF do Paraná, 1990. p.134-139. 
LORUSSO, D.C.S. Gestão de áreas verdes urbanas. In: CONGRESSO BRASILEIRO SOBRE ARBORIZAÇÃO URBANA, 1.; ENCONTRO NACIONAL SOBRE ARBORIZAÇÃO URBANA, 4., Vitória, 1992. Anais. Vitória: Prefeitura, 1992. v. 1, p. 105-118.

MACEDO, S.S. Quadro de paisagismo no Brasil. São Paulo: Macedo, 1999. 144 p. (Coleção Quapá, 1).

MACEDO, S.S.; NUCCI, J.C.; WINTERS, G.; RESENDE, A.P.S.; TANGARI, V.R.; GOYA, C.R. Planejamento da paisagem urbana. In: ENCONTRO PARA CONSERVÇÃO DA NATUREZA, 1., Viçosa, 1997. Anais. Viçosa: CMCN, 1997. p. 323-58.

MARTINS, S.V.; PAIVA, H.N. de; SOARES, C.P.B.; JACOVINE, L.A.G. Avaliação quali-quantitativa da arborização de ruas de Viçosa-MG. In: CONGRESSO BRASILEIRO SOBRE ARBORIZAÇÃO URBANA, 1., Vitória, 1992. Anais. Vitória: Prefeitura, 1992. v.2, p.317-326.

MELlO FILHO, L.E. de. Vegetação e espaço urbano. Boletim da FBCN, n.17, p. $5-15,1982$.

MELLO FILHO, L.E. de. Arborização urbana. In: ENCONTRO NACIONAL SOBRE ARBORIZAÇÃO URBANA, Porto Alegre, 1985. Contribuições técnico-científicas. Porto Alegre: Secretaria Municipal do Meio Ambiente, 1985. p.117-127.

MICHI, S.M.P.; COUTO, H.T.Z. do. Estudo de dois métodos de amostragem de árvores de rua na cidade de Piracicaba - SP. In: CONGRESSO BRASILEIRO DE ARBORIZAÇÃO URBANA, Salvador, 1996. Anais. Salvador: s. ed., 1996. p. 89-96.

MILANO, M.S. Planejamento da arborização urbana: relações entre áreas verdes e ruas arborizadas. In: ENCONTRO NACIONAL SOBRE ARBORIZAÇÃO URBANA, 3., Curitiba, 1990. Anais. Curitiba: FUPEF do Paraná, 1990. p.60-71. 
MILANO, M. S.; DALCIN, E. Arborização de vias públicas. Rio de Janeiro: Light 2000. 226 p.

MILANO, M.S.; SOARES, R.V. Aplicação de técnicas de amostragem aleatória para avaliação da arborização de ruas da Maringá (PR). In ENCONTRO NACIONAL SOBRE ARBORIZAÇÃO URBANA, 3., Curitiba, 1990. Anais. Curitiba: FUPEF do Paraná, 1990. p. 244-251.

MILANO, M.S.; SARNOWSKI FILHO, O.; ROBAYO, J.A.M. Estudo comparativo de unidades amostrais utilizadas para inventário quali-quantitativo de arborização de ruas em Curitiba. In: CONGRESSO BRASILEIRO SOBRE ARBORIZAÇÃO URBANA, 1.; ENCONTRO NACIONAL SOBRE ARBORIZAÇÃO URBANA, 4., Vitória, 1992. Anais. Vitória: Prefeitura, 1992a. v. 2, p.343-350.

MILANO, M.S.; NUNES, M. L.; SANTOS L.A. dos; SARNOWSKI FILHO, O.; ROBAYO, J.A.M. Aspectos quali-quantitativos da arborização de ruas de Curitiba (1991). In: CONGRESSO BRASILEIRO SOBRE ARBORIZAÇÃO URBANA, 1.; ENCONTRO NACIONAL SOBRE ARBORIZAÇÃO URBANA, 4., Vitória, 1992. Anais. Vitória: Prefeitura, 1992b, v.2, p.199-210.

MILANO, M.S.; WANDEMBRUCK, A.; DALLA, A.C.; SIQUEIRA, E.S.; KALIL,F.A., ZECCHINELLI, I.S.; GATTI, M.; MORES, M.; LINHARES, M.A.; HORTA, M.M.M.; SANT'ANNA, A.L.V.; BRITO, F.A.N.; SIMÕES,J.M.; SADETTI, M.; CEBIN, R.; CONEGIAN, S.J.G.; PEREIRA, S.V.; RESENDE, S.A. Situação da arborização de Vitória - ES. In: CONGRESSO BRASILEIRO SOBRE ARBORIZAÇÃO URBANA, 1; ENCONTRO NACIONAL SOBRE ARBORIZAÇÃO URBANA, 4., Vitória, 1992. Anais. Vitória: Prefeitura, 1992c. v.1, p. 147-159.

MILLER, R.W. Urban forestry: planning and managing urban greenspaces. 2.ed. New Jersey: Prentice-Hall, 1996. 502 p.

MOTTA, G.L.O. Inventário da arborização de áreas, utilizando um sistema hierárquico para endereço impreciso. Viçosa, 1998. 124 p. Dissertação (Mestrado) - Universidade Federal de Viçosa. 
NUCCI, J.C. Qualidade ambiental e adensamento urbano: um estudo de ecologia e planejamento da paisagem aplicado ao distrito de Santa Cecília (MSP). São Paulo: USP, FFLCH, 2001. 236 p.

NUCCI, J.C.; CAVALHEIRO, F. Espaços livres e qualidade de vida urbana. In: CONGRESSO BRASILEIRO DE ARBORIZAÇÃO URBANA, 3., Salvador, 1996. Anais. Salvador: Plantarum, 1996. p. 172-176.

OLIVEIRA, J.B. de. Solos do Estado de São Paulo: descrição das classes registradas no mapa pedológico. Campinas: Instituto Agronômico, 1999. 112p. (IAC. Boletim Científico, 45.).

OLIVEIRA, J.B. de; CAMARGO, M.N.; ROSSI, M.; CALDERANO FILHO, B. Mapa pedológico do Estado de São Paulo: legenda expandida. Campinas: Instituto Agronômico de Campinas; Rio de Janeiro: Embrapa Solos, 1999. 64p. Escala 1:100.000.

PORTO ALEGRE. Prefeitura Municipal. Secretaria Municipal de Meio Ambiente. Cartilha dos conselheiros. Porto Alegre, 2001. 13p.

RACHID, C. Estudo da eficiência de dois métodos de amostragem de árvores de rua na cidade de São Carlos - SP. Piracicaba, 1999. 99 p. Dissertação (Mestrado) Escola Superior de Agricultura “Luiz de Queiroz”, Universidade de São Paulo.

RODRIGUES, M.G.R.; BREDT, A.; UIEDA, W. Arborização de Brasília, Distrito Federal, e possíveக் fontes para morcegos fitófagos. In: CONGRESSO BRASILEIRO DE ARBORIZAÇÃO URBANA, 2.; ENCONTRO NACIONAL SOBRE ARBORIZAÇÃO URBANA, 5., São Luís, 1994. Anais. São Luís: Sociedade Brasileira de Arborização Urbana, 1994. p. 331-326.

SANCHOTENE, M.C. Desenvolvimento e perspectivas da arborização urbana no Brasil. In: CONGRESSO BRASILEIRO DE ARBORIZAÇÃO URBANA, 2.; ENCONTRO NACIONAL SOBRE ARBORIZAÇÃO URBANA, 5., São Luís, 1994. Anais. São Luís: Sociedade Brasileira de Arborização Urbana, 1994. p. $15-26$. 
SANTIAGO, A.C. Arborização das cidades. Campinas: CATI, 1985. 18p. n.90.

SANTOS, N.R.Z. dos; TEIXEIRA I.F. Levantamento quantitativo e qualitativo da arborização do bairro centro da cidade de Santa Maria - RS. In: ENCONTRO NACIONAL SOBRE ARBORIZAÇÃO URBANA, 3., Curitiba, 1990. Anais. Curitiba: FUPEF do Paraná, 1990. p. 263-275.

SANTOS, N.R.Z. dos; TEIXEIRA, I.F. Avaliação plástica da vegetação das praças de Veranópolis (RS). In: ENCONTRO NACIONAL SOBRE ARBORIZAÇÃO URBANA, 6.,Brasília (compact disc). 2001. Anais. Brasília: s. ed., 2001.

SANTOS, N.R.Z. dos; TEIXEIRA I.F.; VACARRO, S. Avaliação qualitativa da arborização da cidade de Bento Gonçalves, RS. Ciência Florestal, v.1, n.1, p 88-99, 1991.

SÃO PAULO (cidade). Eletropaulo Metropolitana Eletricidade de São Paulo S.A./Prefeitura do Município de São Paulo. Guia de arborização urbana: manual de poda. São Paulo, s.d. 71p.

SÃO PAULO (Estado). Secretaria do Meio Ambiente. Coordenadoria de Informações Técnicas. Instituto Florestal. Inventário Florestal do Estado de São Paulo. São Paulo: 1993. p.65.

SOCIEDADE BRASILEIRA DE ARBORIZAÇÃO URBANA. "Carta a Londrina e Ibiporã”. Boletim Informativo, v.3 , n.5, p.3, mar., 1996.

SEGAWA, H. Ao amor do público: jardins do Brasil. São Paulo: Studio Nobel; FAPESP, 1996. 255p.

SERAFIM, L. Considerações gerais sobre arborização e ornamentação de ruas e praças do Estado de São Paulo. São Paulo, 1951. São Paulo: Secretaria da Agricultura, Serviço Florestal do Estado, 1951. 4p.

SILVA, A.G. Avaliação da arborização no perímetro urbano de Cajuri-MG, pelo método do quadro sintético. Viçosa, 2000. 150 p. Dissertação (M.S.) Universidade Federal de Viçosa. 
SOARES, M.P. Verdes urbanos e rurais: orientação para arborização de cidades e sítios campesinos. Porto Alegre: Cinco Continentes,1998. 242 p.

SOUSA, M.A.L.B.; BUENO, O.C. Planejamento da arborização urbana. In: CONGRESSO BRASILEIRO DE ARBORIZAÇÃO URBANA, 5., Rio de Janeiro, 2000. Minicurso. Rio de Janeiro: Prefeitura, 2000. p.1-31.

SOUSA, M.A.L.B.; FIORAVANTE,A.P.; CRUZ, R.A. Levantamento e classificação das áreas verdes da zona urbana de Botucatu, SP. In: CONGRESSO BRASILEIRO SOBRE ARBORIZAÇÃO URBANA, 1.; ENCONTRO NACIONAL SOBRE ARBORIZAÇÃO URBANA, 4., Vitória, 1992. Anais. Vitória: Prefeitura, 1992. v.2, p.239-252.

SOUSA, M.A.L.B.; CONTE, A.M.; BARDELLI, G.; LATINI, M. Análise e caracterização da arborização viária da parte central da cidade de Botucatu - SP. In: ENCONTRO NACIONAL SOBRE ARBORIZAÇÃO URBANA, 3., Curitiba, 1990. Anais. Curitiba: FUPEF do Paraná, 1990. p. 236-243.

TAKAHASHI, L.Y. Arborização urbana: inventário. In: CONGRESSO BRASILEIRO DE ARBORIZAÇÃO URBANA, 2.; ENCONTRO NACIONAL SOBRE ARBORIZAÇÃO URBANA, 5., São Luís, 1994. Anais. São Luís: Sociedade Brasileira de Arborização Urbana, 1994. p. 193-199.

TEIXEIRA, I.F.; SANTOS, N.R.Z. dos; HURTADO, R.R. de. Avaliação da Vegetação das ruas e áreas verdes nos loteamentos da cidade de Santa Maria RS. In: CONGRESSO BRASILEIRO DE ARBORIZAÇÃO URBANA, 2.; ENCONTRO NACIONAL SOBRE ARBORIZAÇÃO URBANA, 5., São Luís, 1994. Anais. São Luís: Sociedade Brasileira de Arborização Urbana, 1994. p. 389-401.

TERRA, C.G. Os jardins no Brasil no século XIX: Glaziou revisitado. 2.ed. Rio de Janeiro: EBA;UUFRJ, 2000. 166 p.

TOLEDO FILHO, D.V. de; PARENTE, P.R. Arborização urbana com essências nativas. São Paulo: Instituto Florestal, 1988. 19-31p.(IF. Boletim Técnico, 42.). 
TRINDADE, A.V.C.; ROCHA, M.P. Avaliação da situação fitossanitária das árvores de praças em Curitiba. In: ENCONTRO NACIONAL SOBRE ARBORIZAÇÃO URBANA, 3., Curitiba, 1990. Anais. Curitiba: FUPEF, 1990. p.324-30.

VELOSO, H.P.; RANGEL FILHO, A.L.R.; LIMA, J.C.A. Classificação da vegetação brasileira, adaptada a um sistema universal. Rio de Janeiro: IBGE, Departamento de Recursos Naturais e Estudos Ambientais, 1991. 124p.

VERAS, L.M.S.C. Plano de arborização de cidades - metodologia. In: CONGRESSO NORDESTINO DE ECOLOGIA, Recife, 1986. Anais. Recife: UFRPE, Departamento de Biologia, 1986. p. 8-14.

VINHEDO. Prefeitura Municipal. Secretaria do Comércio, Indústria e Turismo. Histórico do município de Vinhedo. Vinhedo, 2000. 15p.

VINHEDO. Prefeitura Municipal. Secretaria de Obras. Planta do município. Vinhedo, 1997. Escala 1:10.000.

WINTERS, G.H.M.; PERRENOUD, L.A.S.; MOHAMED, E.M.H.M. A arborização urbana em 295 municípios de São Paulo. In: CONGRESSO BRASILEIRO SOBRE ARBORIZAÇÃO URBANA, 1; ENCONTRO NACIONAL SOBRE ARBORIZAÇÃO URBANA, 4., Vitória, 1992. Anais. Vitória: Prefeitura, 1992. v. 2, p. 175-192. 
APÊNDICE 
Coordenadas das espécies arbóreas existentes nas praças da cidade de Vinhedo (SP), 2002. (*)

\begin{tabular}{|c|c|c|c|}
\hline Praça & Nome Comum & Latitude & Longitude \\
\hline B1P1 & Sibipiruna & $\mathrm{S} 23^{\circ} 00^{\prime} 51.8^{\prime \prime}$ & WO 46 $58^{\prime} 32.2^{\prime \prime}$ \\
\hline B1P1 & Espatódea & S $23^{\circ} 00^{\prime} 51.4^{\prime \prime}$ & WO $46^{\circ} 58^{\prime} 31.8^{\prime \prime}$ \\
\hline B1P1 & Sibipiruna & S $23^{\circ} 00^{\prime} 51.7^{\prime \prime}$ & WO $46^{\circ} 58^{\prime} 31.6^{\prime \prime}$ \\
\hline B1P1 & Sibipiruna & S $23^{\circ} 00^{\prime} 51.6^{\prime \prime}$ & WO $46^{\circ} 58^{\prime} 31.1^{\prime \prime}$ \\
\hline B1P1 & Espatódea & S $23^{\circ} 00^{\prime} 51.4^{\prime \prime}$ & WO $46^{\circ} 58^{\prime} 31.3^{\prime \prime}$ \\
\hline B1P1 & Sibipiruna & $\mathrm{S} 23^{\circ} 00^{\prime} 51.3^{\prime \prime}$ & WO $46^{\circ} 58^{\prime} 31.4^{\prime \prime}$ \\
\hline B1P1 & Espatódea & S $23^{\circ} 00^{\prime} 51.2^{\prime \prime}$ & WO $46^{\circ} 58^{\prime} 31.6^{\prime \prime}$ \\
\hline B1P1 & Espatódea & $\mathrm{S} 23^{\circ} 00^{\prime} 51.0^{\prime \prime}$ & WO $46^{\circ} 58^{\prime} 31.8^{\prime \prime}$ \\
\hline B1P1 & Sibipiruna & $\mathrm{S} 23^{\circ} 00^{\prime} 51.0^{\prime \prime}$ & WO $46^{\circ} 58^{\prime} 32.0^{\prime \prime}$ \\
\hline B1P1 & Sibipiruna & $\mathrm{S} 23^{\circ} 00^{\prime} 51.4^{\prime \prime}$ & WO $46^{\circ} 58^{\prime} 32.1^{\prime \prime}$ \\
\hline B1P1 & Espatódea & S $23^{\circ} 00^{\prime} 51.3^{\prime \prime}$ & WO $46^{\circ} 58^{\prime} 32.1^{\prime \prime}$ \\
\hline B1P2 & Sibipiruna & S $23^{\circ} 00^{\prime} 52.8^{\prime \prime}$ & WO $46^{\circ} 58^{\prime} 39.4^{\prime \prime}$ \\
\hline B1P2 & Pata de vaca & $\mathrm{S} 23^{\circ} 00^{\prime} 52.6^{\prime \prime}$ & WO $46^{\circ} 58^{\prime} 39.6^{\prime \prime}$ \\
\hline B1P2 & Sibipiruna & $\mathrm{S} 23^{\circ} 00^{\prime} 52.0^{\prime \prime}$ & WO $46^{\circ} 58^{\prime} 39.3^{\prime \prime}$ \\
\hline B1P2 & Sibipiruna & S $23^{\circ} 00^{\prime} 52.5^{\prime \prime}$ & WO $46^{\circ} 58^{\prime} 39.5^{\prime \prime}$ \\
\hline B1P2 & Cinamomo & S $23^{\circ} 00^{\prime} 52.3^{\prime \prime}$ & WO $46^{\circ} 58^{\prime} 39.8^{\prime \prime}$ \\
\hline B1P2 & Sibipiruna & S $23^{\circ} 00^{\prime} 51.3^{\prime \prime}$ & WO $46^{\circ} 58^{\prime} 39.5^{\prime \prime}$ \\
\hline B1P2 & Cipreste italiano & S $23^{\circ} 00^{\prime} 51.5^{\prime \prime}$ & WO $46^{\circ} 58^{\prime} 39.5^{\prime \prime}$ \\
\hline B1P2 & Sibipiruna & S $23^{\circ} 00^{\prime} 51.8^{\prime \prime}$ & WO $46^{\circ} 58^{\prime} 40.1^{\prime \prime}$ \\
\hline B1P3 & Sibipiruna & S $23^{\circ} 00^{\prime} 53.6^{\prime \prime}$ & WO $46^{\circ} 58^{\prime} 37.6^{\prime \prime}$ \\
\hline B1P3 & Flamboyant & S $23^{\circ} 00^{\prime} 53.6^{\prime \prime}$ & WO $46^{\circ} 58^{\prime} 37.5^{\prime \prime}$ \\
\hline B1P3 & Sibipiruna & $\mathrm{S} 23^{\circ} 00^{\prime} 53.5^{\prime \prime}$ & WO $46^{\circ} 58^{\prime} 37.8^{\prime \prime}$ \\
\hline B1P3 & Sibipiruna & $\mathrm{S} 23^{\circ} 00^{\prime} 53.6^{\prime \prime}$ & WO $46^{\circ} 58^{\prime} 38.5^{\prime \prime}$ \\
\hline B1P3 & Sibipiruna & $\mathrm{S} 23^{\circ} 00^{\prime} 54.0^{\prime \prime}$ & WO $46^{\circ} 58^{\prime} 38.3^{\prime \prime}$ \\
\hline B1P3 & Sibipiruna & $\mathrm{S} 23^{\circ} 00^{\prime} 54.2^{\prime \prime}$ & WO $46^{\circ} 58^{\prime} 38.0^{\prime \prime}$ \\
\hline B1P3 & Flamboyant & $\mathrm{S} 23^{\circ} 00^{\prime} 54.0^{\prime \prime}$ & WO $46^{\circ} 58^{\prime} 37.9^{\prime \prime}$ \\
\hline B1P3 & Mangueira & $\mathrm{S} 23^{\circ} 00^{\prime} 53.9^{\prime \prime}$ & WO $46^{\circ} 58^{\prime} 38.0^{\prime \prime}$ \\
\hline B1P3 & Flamboyant & $\mathrm{S} 23^{\circ} 00^{\prime} 53.9^{\prime \prime}$ & WO $46^{\circ} 58^{\prime} 37.9^{\prime \prime}$ \\
\hline B1P3 & Sibipiruna & $\mathrm{S} 23^{\circ} 00^{\prime} 53.0^{\prime \prime}$ & WO $46^{\circ} 58^{\prime} 37.7^{\prime \prime}$ \\
\hline B1P3 & Sibipiruna & S $23^{\circ} 00^{\prime} 54.1^{\prime \prime}$ & WO $46^{\circ} 58^{\prime} 37.5^{\prime \prime}$ \\
\hline B1P3 & Sibipiruna & $\mathrm{S} 23^{\circ} 00^{\prime} 54.3^{\prime \prime}$ & WO $46^{\circ} 58^{\prime} 37.5^{\prime \prime}$ \\
\hline B1P3 & Flamboyant & $\mathrm{S} 23^{\circ} 00^{\prime} 54.4^{\prime \prime}$ & WO $46^{\circ} 58^{\prime} 37.4^{\prime \prime}$ \\
\hline B1P4 & Sibipiruna & $\mathrm{S} 23^{\circ} 00^{\prime} 53.0^{\prime \prime}$ & WO $46^{\circ} 58^{\prime} 44.4^{\prime \prime}$ \\
\hline B1P4 & Palmeira seafortia & $\mathrm{S} 23^{\circ} 00^{\prime} 52.9^{\prime \prime}$ & WO $46^{\circ} 58^{\prime} 44.4^{\prime \prime}$ \\
\hline B1P4 & Pata de vaca & $\mathrm{S} 23^{\circ} 00^{\prime} 52.6^{\prime \prime}$ & WO $46^{\circ} 58^{\prime} 44.3^{\prime \prime}$ \\
\hline B1P4 & Figueira benjamina & $\mathrm{S} 23^{\circ} 00^{\prime} 52.7^{\prime \prime}$ & WO $46^{\circ} 58^{\prime} 44.3^{\prime \prime}$ \\
\hline B1P4 & Jerivá & S $23^{\circ} 00^{\prime} 52.7^{\prime \prime}$ & WO $46^{\circ} 58^{\prime} 43.9^{\prime \prime}$ \\
\hline B1P4 & Sibipiruna & S $23^{\circ} 00^{\prime} 52.6^{\prime \prime}$ & WO $46^{\circ} 58^{\prime} 44.2^{\prime \prime}$ \\
\hline B1P4 & Jacarandá mimoso & S $23^{\circ} 00^{\prime} 52.2^{\prime \prime}$ & WO $46^{\circ} 58^{\prime} 44.0^{\prime \prime}$ \\
\hline B1P4 & Sibipiruna & S $23^{\circ} 00^{\prime} 52.4^{\prime \prime}$ & WO $46^{\circ} 58^{\prime} 43.6^{\prime \prime}$ \\
\hline B1P4 & Pau-Brasil & S $23^{\circ} 00^{\prime} 52.2^{\prime \prime}$ & WO $46^{\circ} 58^{\prime} 43.7^{\prime \prime}$ \\
\hline B1P4 & Sibipiruna & S $23^{\circ} 00^{\prime} 52.0^{\prime \prime}$ & WO $46^{\circ} 58^{\prime} 42.8^{\prime \prime}$ \\
\hline B1P4 & Ligustro & S $23^{\circ} 00^{\prime} 51.9^{\prime \prime}$ & WO $46^{\circ} 58^{\prime} 43.5^{\prime \prime}$ \\
\hline B1P4 & Peroba branca & $\mathrm{S} 23^{\circ} 00^{\prime} 52.0^{\prime \prime}$ & WO $46^{\circ} 58^{\prime} 42.6^{\prime \prime}$ \\
\hline B1P4 & Chapéu de napoleão & S $23^{\circ} 00^{\prime} 52.6^{\prime \prime}$ & WO $46^{\circ} 58^{\prime} 41.9^{\prime \prime}$ \\
\hline
\end{tabular}




\begin{tabular}{|c|c|c|c|}
\hline Praça & Nome Comum & Latitude & Longitude \\
\hline B1P4 & Sibipiruna & $\mathrm{S} 23^{\circ} 00^{\prime} 52.6^{\prime \prime}$ & WO 46 58' 41.7" \\
\hline B1P4 & Guaraná Paulista & $\mathrm{S} 23^{\circ} 00^{\prime} 51.7^{\prime \prime}$ & WO $46^{\circ} 58^{\prime} 42.5^{\prime \prime}$ \\
\hline B1P4 & Pinus & $\mathrm{S} 23^{\circ} 00^{\prime} 52.0^{\prime \prime}$ & WO $46^{\circ} 58^{\prime} 41.9^{\prime \prime}$ \\
\hline B1P4 & Jambolão & $\mathrm{S} 23^{\circ} 00^{\prime} 51.9^{\prime \prime}$ & WO $46^{\circ} 58^{\prime} 41.8^{\prime \prime}$ \\
\hline B1P4 & Cereja do Rio Grande & $\mathrm{S} 23^{\circ} 00^{\prime} 51.8^{\prime \prime}$ & WO $46^{\circ} 58^{\prime} 42.0^{\prime \prime}$ \\
\hline B1P4 & Ipê amarelo & $\mathrm{S} 23^{\circ} 00^{\prime} 52.1^{\prime \prime}$ & WO $46^{\circ} 58^{\prime} 42.1^{\prime \prime}$ \\
\hline B1P4 & Chapéu de Napoleão & $\mathrm{S} 23^{\circ} 00^{\prime} 52.3^{\prime \prime}$ & WO $46^{\circ} 58^{\prime} 42.3^{\prime \prime}$ \\
\hline B1P4 & Figueira benjamina & $\mathrm{S} 23^{\circ} 00^{\prime} 51.8^{\prime \prime}$ & WO $46^{\circ} 58^{\prime} 42.0^{\prime \prime}$ \\
\hline B1P4 & Pata de vaca & $\mathrm{S} 23^{\circ} 00^{\prime} 52.1^{\prime \prime}$ & WO $46^{\circ} 58^{\prime} 41.4^{\prime \prime}$ \\
\hline B1P4 & Cerejinha & $\mathrm{S} 23^{\circ} 00^{\prime} 52.2^{\prime \prime}$ & WO $46^{\circ} 58^{\prime} 42.3^{\prime \prime}$ \\
\hline B1P4 & Palmeira & $\mathrm{S} 23^{\circ} 00^{\prime} 52.0^{\prime \prime}$ & WO $46^{\circ} 58^{\prime} 42.0^{\prime \prime}$ \\
\hline B1P4 & Sibipiruna & $\mathrm{S} 23^{\circ} 00^{\prime} 52.4^{\prime \prime}$ & WO $46^{\circ} 58^{\prime} 42.8^{\prime \prime}$ \\
\hline B1P4 & Sibipiruna & $\mathrm{S} 23^{\circ} 00^{\prime} 52.2^{\prime \prime}$ & WO $46^{\circ} 58^{\prime} 42.5^{\prime \prime}$ \\
\hline B1P4 & Falsa murta & $\mathrm{S} 23^{\circ} 00^{\prime} 52.3^{\prime \prime}$ & WO $46^{\circ} 58^{\prime} 43.2^{\prime \prime}$ \\
\hline B1P4 & Sibipiruna & $\mathrm{S} 23^{\circ} 00^{\prime} 52.8^{\prime \prime}$ & WO $46^{\circ} 58^{\prime} 43.2^{\prime \prime}$ \\
\hline B1P4 & Munguba & $\mathrm{S} 23^{\circ} 00^{\prime} 52.5^{\prime \prime}$ & WO $46^{\circ} 58^{\prime} 43.0^{\prime \prime}$ \\
\hline B1P4 & Espatódea & $\mathrm{S} 23^{\circ} 00^{\prime} 52.6^{\prime \prime}$ & WO $46^{\circ} 58^{\prime} 43.5^{\prime \prime}$ \\
\hline B1P4 & Sibipiruna & $\mathrm{S} 23^{\circ} 00^{\prime} 52.7^{\prime \prime}$ & WO $46^{\circ} 58^{\prime} 43.5^{\prime \prime}$ \\
\hline B1P4 & Figueira benjamina & $\mathrm{S} 23^{\circ} 00^{\prime} 52.4^{\prime \prime}$ & WO $46^{\circ} 58^{\prime} 44.0^{\prime \prime}$ \\
\hline B1P4 & Pata de vaca & $\mathrm{S} 23^{\circ} 00^{\prime} 53.1^{\prime \prime}$ & WO $46^{\circ} 58^{\prime} 44.1^{\prime \prime}$ \\
\hline B1P5 & Mangueira & $\mathrm{S} 23^{\circ} 00^{\prime} 53.4^{\prime \prime}$ & WO $46^{\circ} 58^{\prime} 30.4^{\prime \prime}$ \\
\hline B1P5 & Paineira & $\mathrm{S} 23^{\circ} 00^{\prime} 53.3^{\prime \prime}$ & WO $46^{\circ} 58^{\prime} 30.2^{\prime \prime}$ \\
\hline B1P5 & Tipuana & $\mathrm{S} 23^{\circ} 00^{\prime} 52.8^{\prime \prime}$ & WO $46^{\circ} 58^{\prime} 30.1^{\prime \prime}$ \\
\hline B1P5 & Tipuana & $\mathrm{S} 23^{\circ} 00^{\prime} 52.9^{\prime \prime}$ & WO $46^{\circ} 58^{\prime} 30.2^{\prime \prime}$ \\
\hline B1P5 & Abacateiro & $\mathrm{S} 23^{\circ} 00^{\prime} 52.9^{\prime \prime}$ & WO $46^{\circ} 58^{\prime} 30.0^{\prime \prime}$ \\
\hline B1P5 & Tipuana & $\mathrm{S} 23^{\circ} 00^{\prime} 53.1^{\prime \prime}$ & WO 46 $58^{\prime} 29.9^{\prime \prime}$ \\
\hline B1P5 & Abacateiro & $\mathrm{S} 23^{\circ} 00^{\prime} 53.2^{\prime \prime}$ & WO $46^{\circ} 58^{\prime} 30.1^{\prime \prime}$ \\
\hline $\mathrm{B} 2 \mathrm{P} 1$ & Resedá & $\mathrm{S} 23^{\circ} 01^{\prime} 36.9^{\prime \prime}$ & WO 46 59' 04.6" \\
\hline $\mathrm{B} 2 \mathrm{P} 1$ & Jerivá & S $23^{\circ} 01^{\prime} 36.7^{\prime \prime}$ & WO 46 $59^{\prime} 04.6^{\prime \prime}$ \\
\hline $\mathrm{B} 2 \mathrm{P} 1$ & Jerivá & S $23^{\circ} 01^{\prime} 36.6^{\prime \prime}$ & WO 46 $59^{\prime} 04.5^{\prime \prime}$ \\
\hline $\mathrm{B} 2 \mathrm{P} 1$ & Jerivá & S $23^{\circ} 01^{\prime} 36.7^{\prime \prime}$ & WO 46 $59^{\prime} 04.4^{\prime \prime}$ \\
\hline $\mathrm{B} 2 \mathrm{P} 1$ & Jerivá & $\mathrm{S} 23^{\circ} 01 ' 36.9^{\prime \prime}$ & WO $46^{\circ} 59^{\prime} 04.5^{\prime \prime}$ \\
\hline $\mathrm{B} 2 \mathrm{P} 1$ & Jerivá & $\mathrm{S} 23^{\circ} 01^{\prime} 38.0 "$ & WO $46^{\circ} 59^{\prime} 03.1^{\prime \prime}$ \\
\hline $\mathrm{B} 2 \mathrm{P} 1$ & Tipuana & $\mathrm{S} 23^{\circ} 01^{\prime} 37.4 "$ & WO 46 $59^{\prime} 03.2^{\prime \prime}$ \\
\hline B2P1 & Jerivá & $\mathrm{S} 23^{\circ} 011^{\prime} 37.0 "$ & WO 46 $59^{\prime} 02.8^{\prime \prime}$ \\
\hline $\mathrm{B} 2 \mathrm{P} 1$ & Jerivá & $\mathrm{S} 23^{\circ} 01^{\prime} 36.8^{\prime \prime}$ & WO 46 $59^{\prime} 03.1^{\prime \prime}$ \\
\hline $\mathrm{B} 2 \mathrm{P} 1$ & Jerivá & $\mathrm{S} 23^{\circ} 01^{\prime} 37.1 "$ & WO 46 $59^{\prime} 03.4^{\prime \prime}$ \\
\hline $\mathrm{B} 2 \mathrm{P} 1$ & Ipê de jardim & $\mathrm{S} 23^{\circ} 01^{\prime} 37.0 "$ & WO 46 $59^{\prime} 03.5^{\prime \prime}$ \\
\hline $\mathrm{B} 2 \mathrm{P} 1$ & Jerivá & $\mathrm{S} 23^{\circ} 01^{\prime} 36.9^{\prime \prime}$ & WO 46 $59^{\prime} 03.7^{\prime \prime}$ \\
\hline $\mathrm{B} 2 \mathrm{P} 1$ & Ligustro & S $23^{\circ} 01^{\prime} 36.9^{\prime \prime}$ & WO $46^{\circ} 59^{\prime} 03.7^{\prime \prime}$ \\
\hline $\mathrm{B} 2 \mathrm{P} 1$ & Jerivá & $\mathrm{S} 23^{\circ} 01^{\prime} 36.3$ " & WO 46 $59^{\prime} 03.1^{\prime \prime}$ \\
\hline $\mathrm{B} 2 \mathrm{P} 1$ & Pau Brasil & $\mathrm{S} 23^{\circ} 01 ' 36.6^{\prime \prime}$ & WO 46 $59^{\prime} 03.2^{\prime \prime}$ \\
\hline B2P1 & Pinus & $\mathrm{S} 23^{\circ} 01^{\prime} 36.5^{\prime \prime}$ & WO 46 $59^{\prime} 03.3^{\prime \prime}$ \\
\hline $\mathrm{B} 2 \mathrm{P} 1$ & Jerivá & S $23^{\circ} 01^{\prime} 36.4^{\prime \prime}$ & WO 46 $59^{\circ} 02.8^{\prime \prime}$ \\
\hline $\mathrm{B} 2 \mathrm{P} 1$ & Jerivá & $\mathrm{S} 23^{\circ} 01^{\prime} 33.2^{\prime \prime}$ & WO 46 $59^{\circ} 02.7^{\prime \prime}$ \\
\hline $\mathrm{B} 2 \mathrm{P} 1$ & Jerivá & $\mathrm{S} 23^{\circ} 01^{\prime} 35.9^{\prime \prime}$ & WO 46 $59^{\circ} 02.5^{\prime \prime}$ \\
\hline $\mathrm{B} 2 \mathrm{P} 1$ & Jerivá & $\mathrm{S} 23^{\circ} 01^{\prime} 35.8^{\prime \prime}$ & WO 46 $59^{\circ} 02.1^{\prime \prime}$ \\
\hline $\mathrm{B} 2 \mathrm{P} 1$ & Jenipapo & S $23^{\circ} 01^{\prime} 35.6^{\prime \prime}$ & WO 46 59' 01.9" \\
\hline $\mathrm{B} 2 \mathrm{P} 1$ & Jerivá & $\mathrm{S} 23^{\circ} 01^{\prime} 35.5^{\prime \prime}$ & WO 46 59' 01.7" \\
\hline $\mathrm{B} 2 \mathrm{P} 1$ & Pinus & $\mathrm{S} 23^{\circ} 01 ' 35,3^{\prime \prime}$ & WO 46 59' 01.5" \\
\hline
\end{tabular}




\begin{tabular}{|c|c|c|c|}
\hline Praça & Nome Comum & Latitude & Longitude \\
\hline $\mathrm{B} 2 \mathrm{P} 1$ & Jerivá & $\mathrm{S} \mathrm{23^{ \circ } 0 1 ^ { \prime } 3 5 . 2 ^ { \prime \prime }}$ & WO 46 59' 01.4" \\
\hline $\mathrm{B} 2 \mathrm{P} 1$ & Jerivá & $\mathrm{S} 23^{\circ} 01^{\prime} 35.3^{\prime \prime}$ & WO 46 59' 01.4" \\
\hline $\mathrm{B} 2 \mathrm{P} 1$ & Não identificado & $\mathrm{S} 23^{\circ} 01^{\prime} 35.1^{\prime \prime}$ & WO 46 $59^{\prime} 01.3^{\prime \prime}$ \\
\hline $\mathrm{B} 2 \mathrm{P} 1$ & Jerivá & $\mathrm{S} 23^{\circ} 01^{\prime} 34.9^{\prime \prime}$ & WO 46 $59^{\prime} 01.2^{\prime \prime}$ \\
\hline $\mathrm{B} 2 \mathrm{P} 1$ & Jerivá & $\mathrm{S} 23^{\circ} 01^{\prime} 34.6^{\prime \prime}$ & WO 46 $59^{\prime} 00.9^{\prime \prime}$ \\
\hline $\mathrm{B} 2 \mathrm{P} 1$ & Tipuana & $\mathrm{S} 23^{\circ} 01^{\prime} 34.5^{\prime \prime}$ & WO 46 $59^{\prime} 00.9^{\prime \prime}$ \\
\hline $\mathrm{B} 2 \mathrm{P} 1$ & Jerivá & $\mathrm{S} 23^{\circ} 01^{\prime} 34.0 "$ & WO 46 $59^{\prime} 01.1^{\prime \prime}$ \\
\hline $\mathrm{B} 2 \mathrm{P} 1$ & Jerivá & $\mathrm{S} 23^{\circ} 01^{\prime} 333.9^{\prime \prime}$ & WO 46 $59^{\prime} 01.4^{\prime \prime}$ \\
\hline $\mathrm{B} 2 \mathrm{P} 1$ & Figueira & $\mathrm{S} 23^{\circ} 01^{\prime} 33.7^{\prime \prime}$ & WO 46 59' 01.7" \\
\hline $\mathrm{B} 2 \mathrm{P} 1$ & Jerivá & $\mathrm{S} 23^{\circ} 01^{\prime} 33.4^{\prime \prime}$ & WO 46 $59^{\prime} 02.0^{\prime \prime}$ \\
\hline $\mathrm{B} 2 \mathrm{P} 1$ & Jerivá & $\mathrm{S} 23^{\circ} 01^{\prime} 33.4^{\prime \prime}$ & WO 46 $59^{\circ} 02.1^{\prime \prime}$ \\
\hline $\mathrm{B} 2 \mathrm{P} 1$ & Tipuana & S $23^{\circ} 01^{\prime} 33.4^{\prime \prime}$ & WO 46 $59^{\prime} 02.4^{\prime \prime}$ \\
\hline $\mathrm{B} 2 \mathrm{P} 1$ & Jerivá & $\mathrm{S} 23^{\circ} 01^{\prime} 33.5^{\prime \prime}$ & WO 46 $59^{\circ} 02.5^{\prime \prime}$ \\
\hline $\mathrm{B} 2 \mathrm{P} 1$ & Jerivá & S $23^{\circ} 01^{\prime} 33.9^{\prime \prime}$ & WO 46 $59^{\prime} 02.9^{\prime \prime}$ \\
\hline $\mathrm{B} 2 \mathrm{P} 1$ & Pinus & $\mathrm{S} 23^{\circ} 01^{\prime} 34.0^{\prime \prime}$ & WO 46 $59^{\prime} 03.3^{\prime \prime}$ \\
\hline $\mathrm{B} 2 \mathrm{P} 1$ & Pinus & $\mathrm{S} 23^{\circ} 01^{\prime} 34.0^{\prime \prime}$ & WO $46^{\circ} 59^{\prime} 03.0^{\prime \prime}$ \\
\hline $\mathrm{B} 2 \mathrm{P} 1$ & Jerivá & $\mathrm{S} 23^{\circ} 01^{\prime} 33.8^{\prime \prime}$ & WO 46 $59^{\prime} 03.1^{\prime \prime}$ \\
\hline $\mathrm{B} 2 \mathrm{P} 1$ & Jerivá & S $23^{\circ} 01^{\prime} 34.3^{\prime \prime}$ & WO 46 $59^{\prime} 03.4^{\prime \prime}$ \\
\hline $\mathrm{B} 2 \mathrm{P} 1$ & Jerivá & S $23^{\circ} 01^{\prime} 34.7^{\prime \prime}$ & WO 46 $59^{\prime} 03.6^{\prime \prime}$ \\
\hline $\mathrm{B} 2 \mathrm{P} 1$ & Jerivá & S $23^{\circ} 01^{\prime} 34.7^{\prime \prime}$ & WO 46 $59^{\prime} 03.4^{\prime \prime}$ \\
\hline $\mathrm{B} 2 \mathrm{P} 1$ & Jerivá & S $23^{\circ} 01^{\prime} 34.7^{\prime \prime}$ & WO $46^{\circ} 59^{\prime} 03.5^{\prime \prime}$ \\
\hline $\mathrm{B} 2 \mathrm{P} 1$ & Jerivá & $\mathrm{S} 23^{\circ} 01^{\prime} 34.7^{\prime \prime}$ & WO 46 $59^{\prime} 03.6^{\prime \prime}$ \\
\hline $\mathrm{B} 2 \mathrm{P} 1$ & Pinus & $\mathrm{S} 23^{\circ} 01^{\prime} 34.8^{\prime \prime}$ & WO 46 59'03.7" \\
\hline B2P1 & Jerivá & $\mathrm{S} 23^{\circ} 01^{\prime} 35.1^{\prime \prime}$ & WO 46 $59^{\prime} 03.7^{\prime \prime}$ \\
\hline $\mathrm{B} 2 \mathrm{P} 1$ & Jerivá & $\mathrm{S} 23^{\circ} 01^{\prime} 35.1^{\prime \prime}$ & WO 46 $59^{\prime} 03.7^{\prime \prime}$ \\
\hline $\mathrm{B} 2 \mathrm{P} 1$ & Jerivá & $\mathrm{S} 23^{\circ} 01^{\prime} 35.1^{\prime \prime}$ & WO 46 $59^{\prime} 03.7^{\prime \prime}$ \\
\hline $\mathrm{B} 2 \mathrm{P} 1$ & Jerivá & S $23^{\circ} 01^{\prime} 35.4^{\prime \prime}$ & WO 46 59' 03.9" \\
\hline B2P1 & Cinamomo & S $23^{\circ} 01^{\prime} 35.7^{\prime \prime}$ & WO 46 59' 04.4" \\
\hline $\mathrm{B} 2 \mathrm{P} 1$ & Pinus & S $23^{\circ} 01^{\prime} 35.8^{\prime \prime}$ & WO 46 $59^{\prime} 04.2^{\prime \prime}$ \\
\hline $\mathrm{B} 2 \mathrm{P} 1$ & Jerivá & $\mathrm{S} 23^{\circ} 01^{\prime} 35.8^{\prime \prime}$ & WO 46 $59^{\prime} 04.2^{\prime \prime}$ \\
\hline $\mathrm{B} 2 \mathrm{P} 1$ & Jerivá & S $23^{\circ} 01^{\prime} 36.0^{\prime \prime}$ & WO 46 $59^{\prime} 04.3^{\prime \prime}$ \\
\hline $\mathrm{B} 2 \mathrm{P} 1$ & Jerivá & S $23^{\circ} 01^{\prime} 36.3^{\prime \prime}$ & WO 46 $59^{\prime} 04.3^{\prime \prime}$ \\
\hline $\mathrm{B} 2 \mathrm{P} 1$ & Jerivá & $\mathrm{S} 23^{\circ} 01^{\prime} 36.5^{\prime \prime}$ & WO $46^{\circ} 59^{\prime} 04.1^{\prime \prime}$ \\
\hline $\mathrm{B} 2 \mathrm{P} 1$ & Pau-Brasil & $\mathrm{S} 23^{\circ} 01^{\prime} 36.7^{\prime \prime}$ & WO $46^{\circ} 59^{\prime} 04.0^{\prime \prime}$ \\
\hline $\mathrm{B} 2 \mathrm{P} 1$ & Mangueira & $\mathrm{S} 23^{\circ} 01^{\prime} 36.1^{\prime \prime}$ & WO 46 $59^{\prime} 02.2^{\prime \prime}$ \\
\hline B2P1 & Tipuana & S $23^{\circ} 01^{\prime} 35.3^{\prime \prime}$ & WO 46 59' 01.3" \\
\hline $\mathrm{B} 2 \mathrm{P} 1$ & Jerivá & S $23^{\circ} 01^{\prime} 33.1^{\prime \prime}$ & WO 46 $59^{\prime} 03.7^{\prime \prime}$ \\
\hline $\mathrm{B} 2 \mathrm{P} 1$ & Tipuana & S $23^{\circ} 01 ' 32.4^{\prime \prime}$ & WO $46^{\circ} 59^{\prime} 01.1^{\prime \prime}$ \\
\hline $\mathrm{B} 2 \mathrm{P} 1$ & Jerivá & S $23^{\circ} 01^{\prime} 32.4^{\prime \prime}$ & WO 46 $59^{\prime} 01.2^{\prime \prime}$ \\
\hline $\mathrm{B} 2 \mathrm{P} 1$ & Tipuana & $\mathrm{S} 23^{\circ} 01^{\prime} 32.5^{\prime \prime}$ & WO 46 $59^{\circ} 01.2^{\prime \prime}$ \\
\hline $\mathrm{B} 2 \mathrm{P} 1$ & Jerivá & $\mathrm{S} 23^{\circ} 01^{\prime} 32.5^{\prime \prime}$ & WO 46 $59^{\prime} 01.5^{\prime \prime}$ \\
\hline $\mathrm{B} 2 \mathrm{P} 1$ & Aroeira & $\mathrm{S} 23^{\circ} 01^{\prime} 32.8^{\prime \prime}$ & WO 46 $59^{\prime} 01.5^{\prime \prime}$ \\
\hline B2P1 & Quaresmeira & S 23 01'32.9" & WO 46 $59^{\circ} 01.7^{\prime \prime}$ \\
\hline $\mathrm{B} 2 \mathrm{P} 1$ & Jerivá & $\mathrm{S} 23^{\circ} 01^{\prime} 33.0^{\prime \prime}$ & WO 46 59'01.8" \\
\hline $\mathrm{B} 2 \mathrm{P} 1$ & Jerivá & $\mathrm{S} 23^{\circ} 01^{\prime} 33.2^{\prime \prime}$ & WO 46 59' 01.8" \\
\hline $\mathrm{B} 2 \mathrm{P} 1$ & Quaresmeira & S $23^{\circ} 01 ' 33.2^{\prime \prime}$ & WO 46 59' 01.3" \\
\hline $\mathrm{B} 2 \mathrm{P} 1$ & Jerivá & $\mathrm{S} 23^{\circ} 01^{\prime} 33.5^{\prime \prime}$ & WO 46 $59^{\circ} 01.6^{\prime \prime}$ \\
\hline B2P1 & Quaresmeira & S $23^{\circ} 01^{\prime} 33.4^{\prime \prime}$ & WO 46 $59^{\prime} 01.5^{\prime \prime}$ \\
\hline $\mathrm{B} 2 \mathrm{P} 1$ & Jerivá & S $23^{\circ} 01 ' 33.7^{\prime \prime}$ & WO $46^{\circ} 59^{\prime} 01.3^{\prime \prime}$ \\
\hline $\mathrm{B} 2 \mathrm{P} 1$ & Quaresmeira & $\mathrm{S} 23^{\circ} 01^{\prime} 33.7^{\prime \prime}$ & WO $46^{\circ} 59^{\prime} 01.2^{\prime \prime}$ \\
\hline
\end{tabular}




\begin{tabular}{|c|c|c|c|}
\hline Praça & Nome Comum & Latitude & Longitude \\
\hline $\mathrm{B} 2 \mathrm{P} 1$ & Quaresmeira & S 23 01'33.9" & WO 46 59' 01.0" \\
\hline $\mathrm{B} 2 \mathrm{P} 1$ & Jerivá & $\mathrm{S} 23^{\circ} 01^{\prime} 33.9^{\prime \prime}$ & WO $46^{\circ} 59^{\prime} 01.1^{\prime \prime}$ \\
\hline $\mathrm{B} 2 \mathrm{P} 1$ & Quaresmeira & $\mathrm{S} 23^{\circ} 01^{\prime} 33.8^{\prime \prime}$ & WO $46^{\circ} 59^{\prime} 00.8^{\prime \prime}$ \\
\hline $\mathrm{B} 2 \mathrm{P} 1$ & Pinus & $\mathrm{S} 23^{\circ} 01^{\prime} 33.9^{\prime \prime}$ & WO $46^{\circ} 59^{\prime} 00.9^{\prime \prime}$ \\
\hline $\mathrm{B} 2 \mathrm{P} 1$ & Pata de vaca & $\mathrm{S} 23^{\circ} 01^{\prime} 33.6^{\prime \prime}$ & WO $46^{\circ} 59^{\prime} 00.6^{\prime \prime}$ \\
\hline $\mathrm{B} 2 \mathrm{P} 1$ & Paineira & $\mathrm{S} 23^{\circ} 01^{\prime} 33.8^{\prime \prime}$ & WO 46 $59^{\prime} 00.7^{\prime \prime}$ \\
\hline $\mathrm{B} 2 \mathrm{P} 1$ & Jerivá & $\mathrm{S} 23^{\circ} 01^{\prime} 34.0^{\prime \prime}$ & WO $46^{\circ} 59^{\prime} 00.4^{\prime \prime}$ \\
\hline B2P1 & Pinus & $\mathrm{S} 23^{\circ} 01^{\prime} 33.6^{\prime \prime}$ & WO $46^{\circ} 59^{\prime} 00.2^{\prime \prime}$ \\
\hline $\mathrm{B} 2 \mathrm{P} 1$ & Pinus & $\mathrm{S} 23^{\circ} 01^{\prime} 33.6^{\prime \prime}$ & WO $46^{\circ} 59^{\prime} 00.2^{\prime \prime}$ \\
\hline $\mathrm{B} 2 \mathrm{P} 1$ & Jerivá & $\mathrm{S} 23^{\circ} 01^{\prime} 33.6^{\prime \prime}$ & WO $46^{\circ} 59^{\prime} 00.1^{\prime \prime}$ \\
\hline $\mathrm{B} 2 \mathrm{P} 1$ & Jerivá & $\mathrm{S} 23^{\circ} 01^{\prime} 33.4^{\prime \prime}$ & WO $46^{\circ} 58^{\prime} 59.8^{\prime \prime}$ \\
\hline $\mathrm{B} 2 \mathrm{P} 1$ & Jerivá & $\mathrm{S} 23^{\circ} 01^{\prime} 33.1^{\prime \prime}$ & WO $46^{\circ} 58^{\prime} 59.4^{\prime \prime}$ \\
\hline $\mathrm{B} 2 \mathrm{P} 1$ & Jerivá & 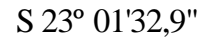 & WO $46^{\circ} 58^{\prime} 59.2^{\prime \prime}$ \\
\hline B2P1 & Figueira branca & $\mathrm{S} 23^{\circ} 01^{\prime} 32.7^{\prime \prime}$ & WO $46^{\circ} 58^{\prime} 59.1^{\prime \prime}$ \\
\hline $\mathrm{B} 2 \mathrm{P} 1$ & Jerivá & $\mathrm{S} 23^{\circ} 01^{\prime} 32.5^{\prime \prime}$ & WO $46^{\circ} 58^{\prime} 58.9^{\prime \prime}$ \\
\hline B2P1 & Jerivá & $\mathrm{S} 23^{\circ} 01^{\prime} 32.2^{\prime \prime}$ & WO $46^{\circ} 58^{\prime} 58.6^{\prime \prime}$ \\
\hline $\mathrm{B} 2 \mathrm{P} 1$ & Jerivá & $\mathrm{S} 23^{\circ} 01^{\prime} 31.9^{\prime \prime}$ & WO $46^{\circ} 58^{\prime} 58.5^{\prime \prime}$ \\
\hline $\mathrm{B} 2 \mathrm{P} 1$ & Tipuana & $\mathrm{S} 23^{\circ} 01^{\prime} 32.0^{\prime \prime}$ & WO $46^{\circ} 58^{\prime} 58.2^{\prime \prime}$ \\
\hline $\mathrm{B} 2 \mathrm{P} 1$ & Jerivá & $\mathrm{S} 23^{\circ} 01^{\prime} 31.7^{\prime \prime}$ & WO $46^{\circ} 58^{\prime} 58.3^{\prime \prime}$ \\
\hline $\mathrm{B} 2 \mathrm{P} 1$ & Jerivá & $\mathrm{S} 23^{\circ} 01^{\prime} 31.0^{\prime \prime}$ & WO $46^{\circ} 58^{\prime} 58.3^{\prime \prime}$ \\
\hline $\mathrm{B} 2 \mathrm{P} 1$ & Jerivá & $\mathrm{S} 23^{\circ} 01^{\prime} 30.8^{\prime \prime}$ & WO $46^{\circ} 58^{\prime} 58.0^{\prime \prime}$ \\
\hline B2P1 & Jerivá & $\mathrm{S} 23^{\circ} 01^{\prime} 30.9^{\prime \prime}$ & WO $46^{\circ} 58^{\prime} 58.3^{\prime \prime}$ \\
\hline $\mathrm{B} 2 \mathrm{P} 1$ & Jerivá & S 23 01'30.9" & WO $46^{\circ} 58^{\prime} 58.3^{\prime \prime}$ \\
\hline $\mathrm{B} 2 \mathrm{P} 1$ & Jerivá & $\mathrm{S} 23^{\circ} 01^{\prime} 31.2^{\prime \prime}$ & WO $46^{\circ} 58^{\prime} 58.4^{\prime \prime}$ \\
\hline $\mathrm{B} 2 \mathrm{P} 1$ & Palmeira seafortia & $\mathrm{S} 23^{\circ} 01^{\prime} 30.6^{\prime \prime}$ & WO $46^{\circ} 58^{\prime} 58.1^{\prime \prime}$ \\
\hline $\mathrm{B} 2 \mathrm{P} 1$ & Jerivá & $\mathrm{S} 23^{\circ} 01^{\prime} 30.5^{\prime \prime}$ & WO $46^{\circ} 58^{\prime} 58.1^{\prime \prime}$ \\
\hline $\mathrm{B} 2 \mathrm{P} 1$ & Figueira branca & 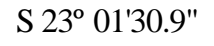 & WO $46^{\circ} 58^{\prime} 57.7^{\prime \prime}$ \\
\hline $\mathrm{B} 2 \mathrm{P} 1$ & Figueira branca & S $23^{\circ} 01^{\prime} 30.9^{\prime \prime}$ & WO $46^{\circ} 58^{\prime} 57.7^{\prime \prime}$ \\
\hline $\mathrm{B} 2 \mathrm{P} 1$ & Jerivá & S $23^{\circ} 01^{\prime 29.9 "}$ & WO $46^{\circ} 58^{\prime} 58.7^{\prime \prime}$ \\
\hline $\mathrm{B} 2 \mathrm{P} 1$ & Jerivá & $\mathrm{S} 23^{\circ} 01^{\prime} 29.8^{\prime \prime}$ & WO $46^{\circ} 59^{\prime} 59.0^{\prime \prime}$ \\
\hline $\mathrm{B} 2 \mathrm{P} 1$ & Tipuana & $\mathrm{S} 23^{\circ} 01^{\prime} 30.0^{\prime \prime}$ & WO $46^{\circ} 58^{\prime} 59.2^{\prime \prime}$ \\
\hline $\mathrm{B} 2 \mathrm{P} 1$ & Jerivá & $\mathrm{S} 23^{\circ} 01^{\prime} 30.1^{\prime \prime}$ & WO $46^{\circ} 58^{\prime} 59.4^{\prime \prime}$ \\
\hline $\mathrm{B} 2 \mathrm{P} 1$ & Munguba & $\mathrm{S} 23^{\circ} 01^{\prime} 30.2^{\prime \prime}$ & WO $46^{\circ} 58^{\prime} 59.5^{\prime \prime}$ \\
\hline $\mathrm{B} 2 \mathrm{P} 1$ & Jerivá & $\mathrm{S} 23^{\circ} 01^{\prime} 30.2^{\prime \prime}$ & WO $46^{\circ} 58^{\prime} 59.8^{\prime \prime}$ \\
\hline B2P1 & Pau Brasil & S 23 01'30.4" & WO $46^{\circ} 58^{\prime} 59.8^{\prime \prime}$ \\
\hline $\mathrm{B} 2 \mathrm{P} 1$ & Jerivá & $\mathrm{S} 23^{\circ} 01^{\prime} 30.5^{\prime \prime}$ & WO $46^{\circ} 59^{\prime} 00.0^{\prime \prime}$ \\
\hline $\mathrm{B} 2 \mathrm{P} 1$ & Figueira branca & $\mathrm{S} 23^{\circ} 01^{\prime} 30.8^{\prime \prime}$ & WO $46^{\circ} 59^{\prime} 00.2^{\prime \prime}$ \\
\hline $\mathrm{B} 2 \mathrm{P} 1$ & Jerivá & $\mathrm{S} 23^{\circ} 01^{\prime} 30.8^{\prime \prime}$ & WO $46^{\circ} 59^{\prime} 00.3^{\prime \prime}$ \\
\hline $\mathrm{B} 2 \mathrm{P} 1$ & Pitangueira & $\mathrm{S} 23^{\circ} 01^{\prime} 31.0^{\prime \prime}$ & WO $46^{\circ} 59^{\prime} 00.4^{\prime \prime}$ \\
\hline B2P1 & Paineira & $\mathrm{S} 23^{\circ} 01^{\prime} 31.3^{\prime \prime}$ & WO $46^{\circ} 59^{\prime} 00.4^{\prime \prime}$ \\
\hline $\mathrm{B} 2 \mathrm{P} 1$ & Jerivá & $\mathrm{S} 23^{\circ} 01^{\prime} 31.3^{\prime \prime}$ & WO $46^{\circ} 59^{\prime} 00.4^{\prime \prime}$ \\
\hline $\mathrm{B} 2 \mathrm{P} 1$ & Jerivá & $\mathrm{S} 23^{\circ} 01^{\prime} 31.6^{\prime \prime}$ & WO 46 59' 00.6" \\
\hline B2P1 & Jerivá & S 230 01'31.9" & WO $46^{\circ} 59^{\prime} 00.8^{\prime \prime}$ \\
\hline $\mathrm{B} 2 \mathrm{P} 1$ & Jerivá & $\mathrm{S} 23^{\circ} 01^{\prime} 32.4^{\prime \prime}$ & WO $46^{\circ} 59^{\prime} 01.1 "$ \\
\hline $\mathrm{B} 2 \mathrm{P} 1$ & Goiabeira & $\mathrm{S} 23^{\circ} 01^{\prime} 32.6^{\prime \prime}$ & WO $46^{\circ} 59^{\prime} 01.0^{\prime \prime}$ \\
\hline $\mathrm{B} 2 \mathrm{P} 1$ & Jerivá & S $23^{\circ} 01^{\prime} 32.6^{\prime \prime}$ & WO $46^{\circ} 59^{\prime} 01.0^{\prime \prime}$ \\
\hline $\mathrm{B} 2 \mathrm{P} 1$ & Pinus & $\mathrm{S} 23^{\circ} 01^{\prime} 33.0^{\prime \prime}$ & WO $46^{\circ} 59^{\prime} 00.9^{\prime \prime}$ \\
\hline $\mathrm{B} 2 \mathrm{P} 1$ & Jerivá & $\mathrm{S} 23^{\circ} 01^{\prime} 32.9^{\prime \prime}$ & WO $46^{\circ} 59^{\prime} 01.0^{\prime \prime}$ \\
\hline $\mathrm{B} 2 \mathrm{P} 1$ & Pata de vaca & $\mathrm{S} 23^{\circ} 01^{\prime} 33.2^{\prime \prime}$ & WO $46^{\circ} 59^{\prime} 00.7^{\prime \prime}$ \\
\hline $\mathrm{B} 2 \mathrm{P} 1$ & Jerivá & $\mathrm{S} 23^{\circ} 01^{\prime} 29.0^{\prime \prime}$ & WO $46^{\circ} 58^{\prime} 58.0^{\prime \prime}$ \\
\hline
\end{tabular}




\begin{tabular}{|c|c|c|c|}
\hline Praça & Nome Comum & Latitude & Longitude \\
\hline $\mathrm{B} 2 \mathrm{P} 1$ & Jerivá & S 23ㅇ 01'29.2" & WO 46 58' 58.1" \\
\hline $\mathrm{B} 2 \mathrm{P} 1$ & Jerivá & S $23^{\circ} 01^{\prime} 29.2^{\prime \prime}$ & WO $46^{\circ} 58^{\prime} 57.9^{\prime \prime}$ \\
\hline $\mathrm{B} 2 \mathrm{P} 1$ & Jerivá & $\mathrm{S} 23^{\circ} 01^{\prime 28.9^{\prime \prime}}$ & WO $46^{\circ} 58^{\prime} 57.8^{\prime \prime}$ \\
\hline $\mathrm{B} 2 \mathrm{P} 1$ & Jerivá & $\mathrm{S} 23^{\circ} 01^{\prime} 28.8^{\prime \prime}$ & WO 46 $58^{\prime} 57.9^{\prime \prime}$ \\
\hline $\mathrm{B} 2 \mathrm{P} 1$ & Jerivá & $\mathrm{S} 23^{\circ} 00^{\prime} 28.8^{\prime \prime}$ & WO $46^{\circ} 58^{\prime} 58.0^{\prime \prime}$ \\
\hline $\mathrm{B} 2 \mathrm{P} 1$ & Jerivá & $\mathrm{S} 23^{\circ} 01^{\prime} 29.1^{\prime \prime}$ & WO $46^{\circ} 58^{\prime} 58.2^{\prime \prime}$ \\
\hline $\mathrm{B} 2 \mathrm{P} 1$ & Jerivá & S $23^{\circ} 01 ' 29.4^{\prime \prime}$ & WO $46^{\circ} 58^{\prime} 58.5^{\prime \prime}$ \\
\hline $\mathrm{B} 2 \mathrm{P} 1$ & Jerivá & S $23^{\circ} 01 ' 29.6^{\prime \prime}$ & WO $46^{\circ} 58^{\prime} 58.4^{\prime \prime}$ \\
\hline B2P1 & Jerivá & S $23^{\circ} 01^{\prime 29.7 "}$ & WO $46^{\circ} 58^{\prime} 58.3^{\prime \prime}$ \\
\hline $\mathrm{B} 2 \mathrm{P} 1$ & Não identificada & $\mathrm{S} 23^{\circ} 01^{\prime} 29.8^{\prime \prime}$ & WO $46^{\circ} 58^{\prime} 58.2^{\prime \prime}$ \\
\hline $\mathrm{B} 2 \mathrm{P} 1$ & Palmeira cariota & $\mathrm{S} 23^{\circ} 01^{\prime} 30.0^{\prime \prime}$ & WO 46 $58^{\prime} 57.9^{\prime \prime}$ \\
\hline $\mathrm{B} 2 \mathrm{P} 1$ & Pata de vaca & S $23^{\circ} 01 ' 29.7^{\prime \prime}$ & WO $46^{\circ} 58^{\prime} 57.7^{\prime \prime}$ \\
\hline $\mathrm{B} 2 \mathrm{P} 1$ & Jerivá & $\mathrm{S} 23^{\circ} 01^{\prime} 30.2^{\prime \prime}$ & WO $46^{\circ} 58^{\prime} 57.8^{\prime \prime}$ \\
\hline $\mathrm{B} 2 \mathrm{P} 1$ & Jerivá & S $23^{\circ} 01^{\prime} 30.6^{\prime \prime}$ & WO $46^{\circ} 58^{\prime} 57.4^{\prime \prime}$ \\
\hline B2P1 & Pau Brasil & S $23^{\circ} 01^{\prime 29.4 "}$ & WO $46^{\circ} 58^{\prime} 58.8^{\prime \prime}$ \\
\hline B2P1 & Jerivá & $\mathrm{S} 23^{\circ} 01^{\prime} 37.1^{\prime \prime}$ & WO 46 $59^{\prime} 03.5^{\prime \prime}$ \\
\hline B2P1 & Jerivá & S $23^{\circ} 01^{\prime} 37.7^{\prime \prime}$ & WO 46 59' 03.7" \\
\hline $\mathrm{B} 2 \mathrm{P} 1$ & Não identificada & S $23^{\circ} 01^{\prime} 37.7^{\prime \prime}$ & WO $46^{\circ} 59^{\prime} 04.0^{\prime \prime}$ \\
\hline $\mathrm{B} 2 \mathrm{P} 1$ & Jerivá & $\mathrm{S} 23^{\circ} 01^{\prime} 37.7^{\prime \prime}$ & WO 46 $59^{\prime} 04.0^{\prime \prime}$ \\
\hline $\mathrm{B} 2 \mathrm{P} 1$ & Jerivá & S $23^{\circ} 01^{\prime} 37.6^{\prime \prime}$ & WO 46 $59^{\prime} 04.1^{\prime \prime}$ \\
\hline $\mathrm{B} 2 \mathrm{P} 1$ & Figueira benjamina & $\mathrm{S} 23^{\circ} 01^{\prime} 37.8^{\prime \prime}$ & WO 46 $59^{\prime} 04.3^{\prime \prime}$ \\
\hline $\mathrm{B} 2 \mathrm{P} 1$ & Jerivá & S $23^{\circ} 01^{\prime} 37.7^{\prime \prime}$ & WO $46^{\circ} 59^{\prime} 04.5^{\prime \prime}$ \\
\hline B2P1 & Jerivá & S $23^{\circ} 01^{\prime} 37.6^{\prime \prime}$ & WO 46 $59^{\prime} 04.6^{\prime \prime}$ \\
\hline B2P1 & Jerivá & $\mathrm{S} 23^{\circ} 01^{\prime} 37.6^{\prime \prime}$ & WO 46 $59^{\prime} 04.8^{\prime \prime}$ \\
\hline $\mathrm{B} 2 \mathrm{P} 1$ & Jerivá & $\mathrm{S} 23^{\circ} 01^{\prime} 37.6^{\prime \prime}$ & WO 46 $59^{\prime} 05.2^{\prime \prime}$ \\
\hline $\mathrm{B} 2 \mathrm{P} 1$ & Jerivá & $\mathrm{S} 23^{\circ} 01^{\prime} 38,1^{\prime \prime}$ & WO $46^{\circ} 59^{\prime} 05.3^{\prime \prime}$ \\
\hline $\mathrm{B} 2 \mathrm{P} 1$ & Jerivá & $\mathrm{S} 23^{\circ} 01^{\prime} 38.5^{\prime \prime}$ & WO 46 $59^{\prime} 05.4^{\prime \prime}$ \\
\hline B2P1 & Jerivá & $\mathrm{S} 23^{\circ} 01^{\prime} 38,3^{\prime \prime}$ & WO $46^{\circ} 59^{\prime} 05.1^{\prime \prime}$ \\
\hline $\mathrm{B} 2 \mathrm{P} 1$ & Jerivá & S $23^{\circ} 01^{\prime} 38.4^{\prime \prime}$ & WO 46 $59^{\prime} 05.1^{\prime \prime}$ \\
\hline $\mathrm{B} 2 \mathrm{P} 1$ & Tipuana & $\mathrm{S} 23^{\circ} 01^{\prime} 38.0^{\prime \prime}$ & WO 46 59' 04.7" \\
\hline $\mathrm{B} 2 \mathrm{P} 1$ & Tipuana & $\mathrm{S} 23^{\circ} 01^{\prime} 37.8^{\prime \prime}$ & WO 46 $59^{\prime} 04.2^{\prime \prime}$ \\
\hline $\mathrm{B} 2 \mathrm{P} 1$ & Jerivá & $\mathrm{S} 23^{\circ} 01^{\prime} 38.5^{\prime \prime}$ & WO 46 $59^{\prime} 04.6^{\prime \prime}$ \\
\hline $\mathrm{B} 2 \mathrm{P} 1$ & Jerivá & $\mathrm{S} 23^{\circ} 01^{\prime} 38.6^{\prime \prime}$ & WO 46 $59^{\prime} 04.3^{\prime \prime}$ \\
\hline $\mathrm{B} 2 \mathrm{P} 1$ & Tipuana & $\mathrm{S} 23^{\circ} 01^{\prime} 38,4^{\prime \prime}$ & WO $46^{\circ} 59^{\prime} 04.3^{\prime \prime}$ \\
\hline $\mathrm{B} 2 \mathrm{P} 1$ & Jerivá & $\mathrm{S} 23^{\circ} 01^{\prime} 38.6^{\prime \prime}$ & WO $46^{\circ} 59^{\prime} 04.2^{\prime \prime}$ \\
\hline $\mathrm{B} 2 \mathrm{P} 1$ & Jerivá & $\mathrm{S} 23^{\circ} 01^{\prime} 38.2^{\prime \prime}$ & WO 46 $59^{\prime} 03.6^{\prime \prime}$ \\
\hline $\mathrm{B} 2 \mathrm{P} 1$ & Jerivá & $\mathrm{S} 23^{\circ} 01^{\prime} 37.9^{\prime \prime}$ & WO 46 59' 03.7" \\
\hline $\mathrm{B} 2 \mathrm{P} 1$ & Jerivá & $\mathrm{S} 23^{\circ} 01^{\prime} 38.6^{\prime \prime}$ & WO 46 $59^{\prime} 04.2^{\prime \prime}$ \\
\hline $\mathrm{B} 2 \mathrm{P} 1$ & Jerivá & $\mathrm{S} 23^{\circ} 01^{\prime} 38.7^{\prime \prime}$ & WO 46 $59^{\prime} 04.3^{\prime \prime}$ \\
\hline $\mathrm{B} 2 \mathrm{P} 1$ & Jerivá & $\mathrm{S} 23^{\circ} 01^{\prime} 39.3^{\prime \prime}$ & WO 46 $59^{\prime} 04.7^{\prime \prime}$ \\
\hline $\mathrm{B} 2 \mathrm{P} 1$ & Jerivá & $\mathrm{S} 23^{\circ} 01^{\prime} 39.8^{\prime \prime}$ & WO 46 $59^{\prime} 05.2^{\prime \prime}$ \\
\hline $\mathrm{B} 2 \mathrm{P} 1$ & Jerivá & $\mathrm{S} 23^{\circ} 01^{\prime} 40.3^{\prime \prime}$ & WO 46 $59^{\prime} 05.0^{\prime \prime}$ \\
\hline $\mathrm{B} 2 \mathrm{P} 1$ & Jerivá & $\mathrm{S} 23^{\circ} 01^{\prime} 40.4^{\prime \prime}$ & WO 46 $59^{\prime} 05.4^{\prime \prime}$ \\
\hline $\mathrm{B} 2 \mathrm{P} 1$ & Jerivá & $\mathrm{S} 23^{\circ} 01^{\prime} 40.0^{\prime \prime}$ & WO 46 $59^{\prime} 05.6^{\prime \prime}$ \\
\hline $\mathrm{B} 2 \mathrm{P} 1$ & Jerivá & $\mathrm{S} 23^{\circ} 01^{\prime} 40.3^{\prime \prime}$ & WO 46 $59^{\prime} 05.5^{\prime \prime}$ \\
\hline $\mathrm{B} 2 \mathrm{P} 1$ & Jerivá & $\mathrm{S} 23^{\circ} 01^{\prime} 39.9^{\prime \prime}$ & WO 46 $59^{\prime} 05.8^{\prime \prime}$ \\
\hline $\mathrm{B} 2 \mathrm{P} 1$ & Jerivá & $\mathrm{S} 23^{\circ} 01^{\prime} 39.5^{\prime \prime}$ & WO 46 $59^{\circ} 05.8^{\prime \prime}$ \\
\hline $\mathrm{B} 2 \mathrm{P} 1$ & Paineira & S $23^{\circ} 01^{\prime} 39.4^{\prime \prime}$ & WO 46 59' 05.7" \\
\hline $\mathrm{B} 2 \mathrm{P} 1$ & Jerivá & S $23^{\circ} 01^{\prime} 39.4^{\prime \prime}$ & WO 46 $59^{\prime} 05.6^{\prime \prime}$ \\
\hline $\mathrm{B} 2 \mathrm{P} 1$ & Jerivá & $\mathrm{S} 23^{\circ} 01^{\prime} 39.1^{\prime \prime}$ & WO 46 $59^{\prime} 05.6^{\prime \prime}$ \\
\hline
\end{tabular}




\begin{tabular}{|c|c|c|c|}
\hline Praça & Nome Comum & Latitude & Longitude \\
\hline $\mathrm{B} 2 \mathrm{P} 1$ & Jerivá & 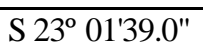 & WO 46 59' 05.4" \\
\hline $\mathrm{B} 2 \mathrm{P} 1$ & Jerivá & S $23^{\circ} 01^{\prime} 38.7^{\prime \prime}$ & WO $46^{\circ} 59^{\prime} 05.5^{\prime \prime}$ \\
\hline $\mathrm{B} 2 \mathrm{P} 1$ & Jerivá & $\mathrm{S} 23^{\circ} 01^{\prime} 38.3^{\prime \prime}$ & WO 46 $59^{\prime} 05.5^{\prime \prime}$ \\
\hline B2P1 & Jerivá & $\mathrm{S} 23^{\circ} 01^{\prime} 38.3^{\prime \prime}$ & WO 46 $59^{\prime} 05.3^{\prime \prime}$ \\
\hline $\mathrm{B} 2 \mathrm{P} 1$ & Jerivá & S $23^{\circ} 01^{\prime} 38.4^{\prime \prime}$ & WO 46 $59^{\prime} 05.1^{\prime \prime}$ \\
\hline $\mathrm{B} 2 \mathrm{P} 1$ & Jerivá & $\mathrm{S} 23^{\circ} 01^{\prime} 38.3^{\prime \prime}$ & WO 46 59' 04.9" \\
\hline $\mathrm{B} 2 \mathrm{P} 1$ & Jerivá & S $23^{\circ} 01^{\prime} 38.7^{\prime \prime}$ & WO 46 $59^{\prime} 04.6^{\prime \prime}$ \\
\hline $\mathrm{B} 2 \mathrm{P} 1$ & Tipuana & $\mathrm{S} 23^{\circ} 01^{\prime} 39.5^{\prime \prime}$ & WO 46 $59^{\prime} 05.4^{\prime \prime}$ \\
\hline $\mathrm{B} 2 \mathrm{P} 2$ & Tipuana & S $23^{\circ} 01^{\prime} 32.4^{\prime \prime}$ & WO 46 $59^{\prime} 03.8^{\prime \prime}$ \\
\hline $\mathrm{B} 2 \mathrm{P} 2$ & Tipuana & $\mathrm{S} 23^{\circ} 01^{\prime} 32.1^{\prime \prime}$ & WO 46 $59^{\prime} 03.1^{\prime \prime}$ \\
\hline $\mathrm{B} 2 \mathrm{P} 2$ & Tipuana & $\mathrm{S} 23^{\circ} 01^{\prime} 32.5^{\prime \prime}$ & WO 46 $59^{\circ} 03.0^{\prime \prime}$ \\
\hline $\mathrm{B} 2 \mathrm{P} 2$ & Paineira & $\mathrm{S} 23^{\circ} 01^{\prime} 31.7^{\prime \prime}$ & WO 46 $59^{\prime} 04.7^{\prime \prime}$ \\
\hline $\mathrm{B} 2 \mathrm{P} 2$ & Tipuana & $\mathrm{S} 23^{\circ} 01^{\prime} 32.4^{\prime \prime}$ & WO 46 $59^{\prime} 02.7^{\prime \prime}$ \\
\hline $\mathrm{B} 2 \mathrm{P} 2$ & Tipuana & $\mathrm{S} 23^{\circ} 01^{\prime} 32.3^{\prime \prime}$ & WO 46 $59^{\prime} 02.4^{\prime \prime}$ \\
\hline $\mathrm{B} 2 \mathrm{P} 2$ & Açoita cavalo & $\mathrm{S} 23^{\circ} 01^{\prime} 31.8^{\prime \prime}$ & WO 46 $59^{\prime} 02.6^{\prime \prime}$ \\
\hline $\mathrm{B} 2 \mathrm{P} 2$ & Espatódea & $\mathrm{S} 23^{\circ} 01^{\prime} 31.9^{\prime \prime}$ & WO 46 $59^{\prime} 02.5^{\prime \prime}$ \\
\hline $\mathrm{B} 2 \mathrm{P} 2$ & Pata de vaca & $\mathrm{S} 23^{\circ} 01^{\prime} 33.1^{\prime \prime}$ & WO 46 $59^{\prime} 02.4^{\prime \prime}$ \\
\hline $\mathrm{B} 2 \mathrm{P} 2$ & Jerivá & S $23^{\circ} 01^{\prime} 32.7^{\prime \prime}$ & WO 46 $59^{\prime} 02.6^{\prime \prime}$ \\
\hline $\mathrm{B} 2 \mathrm{P} 2$ & Figueira branca & $\mathrm{S} 23^{\circ} 01^{\prime} 31.6^{\prime \prime}$ & WO 46 $59^{\prime} 02.5^{\prime \prime}$ \\
\hline $\mathrm{B} 2 \mathrm{P} 2$ & Tipuana & $\mathrm{S} 23^{\circ} 01^{\prime} 32.1^{\prime \prime}$ & WO 46 $59^{\prime} 03.3^{\prime \prime}$ \\
\hline $\mathrm{B} 2 \mathrm{P} 2$ & Ligustro & $\mathrm{S} 23^{\circ} 01^{\prime} 31.9^{\prime \prime}$ & WO 46 $59^{\prime} 03.4^{\prime \prime}$ \\
\hline $\mathrm{B} 2 \mathrm{P} 2$ & Ligustro & S $23^{\circ} 01^{\prime} 31.8^{\prime \prime}$ & WO $46^{\circ} 59^{\prime} 03.2^{\prime \prime}$ \\
\hline $\mathrm{B} 2 \mathrm{P} 2$ & Tipuana & S $23^{\circ} 01^{\prime} 31.6^{\prime \prime}$ & WO $46^{\circ} 59^{\prime} 03.7^{\prime \prime}$ \\
\hline B3P1 & Sibipiruna & $\mathrm{S} 23^{\circ} 01^{\prime} 48.1^{\prime \prime}$ & WO $46^{\circ} 58^{\prime} 58.6^{\prime \prime}$ \\
\hline B3P1 & Sibipiruna & $\mathrm{S} 23^{\circ} 01^{\prime} 47.9^{\prime \prime}$ & WO 46 $58^{\prime} 59.4^{\prime \prime}$ \\
\hline B3P1 & Sibipiruna & $\mathrm{S} 23^{\circ} 01^{\prime} 48.2^{\prime \prime}$ & WO $46^{\circ} 58^{\prime} 58.7^{\prime \prime}$ \\
\hline B3P1 & Sibipiruna & $\mathrm{S} 23^{\circ} 01^{\prime} 46^{\prime \prime}$ & WO $46^{\circ} 58^{\prime} 58.4^{\prime \prime}$ \\
\hline B3P1 & Sibipiruna & $\mathrm{S} 23^{\circ} 01^{\prime} 47.6^{\prime \prime}$ & WO $46^{\circ} 58^{\prime} 59.1^{\prime \prime}$ \\
\hline B3P1 & Sibipiruna & S $23^{\circ} 01^{\prime} 47.2^{\prime \prime}$ & WO 46 $58^{\prime} 58.9^{\prime \prime}$ \\
\hline B3P1 & Sibipiruna & $\mathrm{S} 23^{\circ} 01^{\prime} 47.5^{\prime \prime}$ & WO 46 $58^{\prime} 59.5^{\prime \prime}$ \\
\hline B3P1 & Goiabeira & $\mathrm{S} 23^{\circ} 01^{\prime} 47.3^{\prime \prime}$ & WO 46 $58^{\prime} 59.7^{\prime \prime}$ \\
\hline B3P1 & Sibipiruna & $\mathrm{S} 23^{\circ} 01^{\prime} 47.6^{\prime \prime}$ & WO $46^{\circ} 58^{\prime} 59.0^{\prime \prime}$ \\
\hline B3P1 & Sibipiruna & $\mathrm{S} 23^{\circ} 01^{\prime} 47.1^{\prime \prime}$ & WO $46^{\circ} 58^{\prime} 58.9^{\prime \prime}$ \\
\hline B3P1 & Sibipiruna & $\mathrm{S} 23^{\circ} 01^{\prime} 47.2^{\prime \prime}$ & WO $46^{\circ} 58^{\prime} 58.7^{\prime \prime}$ \\
\hline B3P1 & Jerivá & $\mathrm{S} 23^{\circ} 01^{\prime} 47.3^{\prime \prime}$ & WO $46^{\circ} 58^{\prime} 59.0^{\prime \prime}$ \\
\hline B3P1 & Jerivá & $\mathrm{S} 23^{\circ} 01^{\prime} 47.1^{\prime \prime}$ & WO $46^{\circ} 58^{\prime} 59.3^{\prime \prime}$ \\
\hline B3P1 & Palmeira seafortia & S $23^{\circ} 01^{\prime} 47.2^{\prime \prime}$ & WO 46 $58^{\prime} 59.5^{\prime \prime}$ \\
\hline B3P1 & Palmeira seafortia & $\mathrm{S} 23^{\circ} 01^{\prime} 47.1^{\prime \prime}$ & WO 46 $58^{\prime} 59.4^{\prime \prime}$ \\
\hline B3P1 & Ligustro & $\mathrm{S} 23^{\circ} 01^{\prime} 47.0^{\prime \prime}$ & WO 46 $58^{\prime} 59.7^{\prime \prime}$ \\
\hline B3P1 & Ligustro & $\mathrm{S} 23^{\circ} 01^{\prime} 46.1^{\prime \prime}$ & WO 46 58' 59.4" \\
\hline B3P1 & Ligustro & $\mathrm{S} 23^{\circ} 01^{\prime} 46.3^{\prime \prime}$ & WO $46^{\circ} 58^{\prime} 59.5^{\prime \prime}$ \\
\hline B3P1 & Ligustro & $\mathrm{S} 23^{\circ} 01^{\prime} 46.4^{\prime \prime}$ & WO $46^{\circ} 58^{\prime} 59.0^{\prime \prime}$ \\
\hline B3P1 & Ligustro & $\mathrm{S} 23^{\circ} 01^{\prime} 46.5^{\prime \prime}$ & WO 46 $58^{\prime} 59.5^{\prime \prime}$ \\
\hline B3P1 & Ligustro & $\mathrm{S} 23^{\circ} 01^{\prime} 47.2^{\prime \prime}$ & WO 46 $58^{\prime} 59.0^{\prime \prime}$ \\
\hline B3P1 & Ligustro & $\mathrm{S} 23^{\circ} 01^{\prime} 47.4^{\prime \prime}$ & WO $46^{\circ} 59^{\prime} 00.0^{\prime \prime}$ \\
\hline B3P1 & Ligustro & $\mathrm{S} 23^{\circ} 01^{\prime} 46.4^{\prime \prime}$ & WO $46^{\circ} 58^{\prime} 59.3^{\prime \prime}$ \\
\hline B3P1 & Não identificado & $\mathrm{S} 23^{\circ} 01^{\prime} 46.4^{\prime \prime}$ & WO $46^{\circ} 58^{\prime} 59.5^{\prime \prime}$ \\
\hline B3P1 & Eritrina & $\mathrm{S} 23^{\circ} 01^{\prime} 46.5^{\prime \prime}$ & WO $46^{\circ} 58^{\prime} 59.2^{\prime \prime}$ \\
\hline B3P1 & Sete copas & $\mathrm{S} 23^{\circ} 01^{\prime} 46.4^{\prime \prime}$ & WO $46^{\circ} 58^{\prime} 59.4^{\prime \prime}$ \\
\hline B3P1 & Flamboyant & $\mathrm{S} 23^{\circ} 01^{\prime} 46.8^{\prime \prime}$ & WO $46^{\circ} 58^{\prime} 59.2^{\prime \prime}$ \\
\hline
\end{tabular}




\begin{tabular}{|c|c|c|c|}
\hline Praça & Nome Comum & Latitude & Longitude \\
\hline B3P1 & Palmeira seafortia & S 23 01'46.6" & WO $46^{\circ} 58^{\prime} 59.4^{\prime \prime}$ \\
\hline B3P1 & Figueira benjamina & $\mathrm{S} 23^{\circ} 01^{\prime} 46.0^{\prime \prime}$ & WO $46^{\circ} 58^{\prime} 59.7^{\prime \prime}$ \\
\hline B3P1 & Flamboyant & $\mathrm{S} 23^{\circ} 01^{\prime} 46.2^{\prime \prime}$ & WO $46^{\circ} 59^{\prime} 00.7^{\prime \prime}$ \\
\hline B3P1 & Abacateiro & $\mathrm{S} 23^{\circ} 01^{\prime} 45.6^{\prime \prime}$ & WO $46^{\circ} 59^{\prime} 00.2^{\prime \prime}$ \\
\hline B3P1 & Mangueira & $\mathrm{S} 23^{\circ} 01^{\prime} 45.5^{\prime \prime}$ & WO $46^{\circ} 59^{\prime} 00.2^{\prime \prime}$ \\
\hline B3P1 & Limoeiro & $\mathrm{S} 23^{\circ} 01^{\prime} 45.4^{\prime \prime}$ & WO $46^{\circ} 59^{\prime} 00.0^{\prime \prime}$ \\
\hline B3P1 & Tipuana & $\mathrm{S} 23^{\circ} 01^{\prime} 45.5^{\prime \prime}$ & WO $46^{\circ} 59^{\prime} 00.3^{\prime \prime}$ \\
\hline B3P2 & Jerivá & $\mathrm{S} 23^{\circ} 02^{\prime} 01.2^{\prime \prime}$ & WO $46^{\circ} 58^{\prime} 56.0^{\prime \prime}$ \\
\hline $\mathrm{B} 3 \mathrm{P} 2$ & Jerivá & $\mathrm{S} 23^{\circ} 02^{\prime} 01.2^{\prime \prime}$ & WO $46^{\circ} 58^{\prime} 55.9^{\prime \prime}$ \\
\hline $\mathrm{B} 3 \mathrm{P} 2$ & Jerivá & $\mathrm{S} 23^{\circ} 02^{\prime} 01.2^{\prime \prime}$ & WO $46^{\circ} 58^{\prime} 55.9^{\prime \prime}$ \\
\hline $\mathrm{B} 3 \mathrm{P} 2$ & Jerivá & $\mathrm{S} 23^{\circ} 02^{\prime} 01.2^{\prime \prime}$ & WO $46^{\circ} 58^{\prime} 56.0^{\prime \prime}$ \\
\hline B3P2 & Jerivá & $\mathrm{S} 23^{\circ} 02^{\prime} 01.2^{\prime \prime}$ & WO $46^{\circ} 58^{\prime} 55.9^{\prime \prime}$ \\
\hline B3P2 & Jerivá & $\mathrm{S} 23^{\circ} 02^{\prime} 01.2^{\prime \prime}$ & WO $46^{\circ} 58^{\prime} 55.9^{\prime \prime}$ \\
\hline B3P2 & Jerivá & $\mathrm{S} 23^{\circ} 02^{\prime} 01.2^{\prime \prime}$ & WO $46^{\circ} 58^{\prime} 55.8^{\prime \prime}$ \\
\hline B3P2 & Jerivá & $\mathrm{S} 23^{\circ} 02^{\prime} 01.3^{\prime \prime}$ & WO $46^{\circ} 58^{\prime} 55.8^{\prime \prime}$ \\
\hline B3P2 & Jerivá & $\mathrm{S} 23^{\circ} 02^{\prime} 01.3^{\prime \prime}$ & WO $46^{\circ} 58^{\prime} 55.7^{\prime \prime}$ \\
\hline $\mathrm{B} 3 \mathrm{P} 2$ & Jerivá & S $23^{\circ} 02^{\prime} 01.4^{\prime \prime}$ & WO $46^{\circ} 58^{\prime} 55.7^{\prime \prime}$ \\
\hline $\mathrm{B} 3 \mathrm{P} 2$ & Jerivá & S $23^{\circ} 02^{\prime} 01.4^{\prime \prime}$ & WO $46^{\circ} 58^{\prime} 55.7^{\prime \prime}$ \\
\hline $\mathrm{B} 3 \mathrm{P} 2$ & Aroeira & $\mathrm{S} 23^{\circ} 02^{\prime} 01.2^{\prime \prime}$ & WO $46^{\circ} 58^{\prime} 55.6^{\prime \prime}$ \\
\hline B3P2 & Aroeira & $\mathrm{S} 23^{\circ} 02^{\prime} 00.9^{\prime \prime}$ & WO $46^{\circ} 58^{\prime} 55.5^{\prime \prime}$ \\
\hline B3P2 & Aroeira & $\mathrm{S} 23^{\circ} 02^{\prime} 00.8^{\prime \prime}$ & WO $46^{\circ} 58^{\prime} 55.5^{\prime \prime}$ \\
\hline B3P2 & Aroeira & $\mathrm{S} 23^{\circ} 02^{\prime} 00.8^{\prime \prime}$ & WO $46^{\circ} 58^{\prime} 55.4^{\prime \prime}$ \\
\hline $\mathrm{B} 3 \mathrm{P} 2$ & Sete copas & $\mathrm{S} 23^{\circ} 02^{\prime} 00.9^{\prime \prime}$ & WO $46^{\circ} 58^{\prime} 55.5^{\prime \prime}$ \\
\hline B4P1 & Jerivá & $\mathrm{S} 23^{\circ} 01^{\prime} 55.2^{\prime \prime}$ & WO $46^{\circ} 58^{\prime} 13.8^{\prime \prime}$ \\
\hline B4P1 & Jerivá & $\mathrm{S} 23^{\circ} 01^{\prime} 55.1^{\prime \prime}$ & WO $46^{\circ} 58^{\prime} 13.6^{\prime \prime}$ \\
\hline B4P1 & Jerivá & $\mathrm{S} 23^{\circ} 01^{\prime} 55.1^{\prime \prime}$ & WO $46^{\circ} 58^{\prime} 13.7^{\prime \prime}$ \\
\hline B4P1 & Jerivá & $\mathrm{S} 23^{\circ} 01^{\prime} 54.8^{\prime \prime}$ & WO $46^{\circ} 58^{\prime} 13.3^{\prime \prime}$ \\
\hline B4P1 & Não identificado & $\mathrm{S} 23^{\circ} 01^{\prime} 54.7^{\prime \prime}$ & WO $46^{\circ} 58^{\prime} 13.1^{\prime \prime}$ \\
\hline B4P1 & Pitangueira** & & \\
\hline B4P1 & Pinus & S $23^{\circ} 01^{\prime} 54.9^{\prime \prime}$ & WO $46^{\circ} 58^{\prime} 13.0^{\prime \prime}$ \\
\hline B4P1 & Palmeira leque** & & \\
\hline B4P1 & Jerivá & $\mathrm{S} 23^{\circ} 01^{\prime} 55.0^{\prime \prime}$ & WO $46^{\circ} 58^{\prime} 13.2^{\prime \prime}$ \\
\hline B4P1 & Jerivá & $\mathrm{S} 23^{\circ} 01^{\prime} 55.0^{\prime \prime}$ & WO $46^{\circ} 58^{\prime} 13.3^{\prime \prime}$ \\
\hline B4P1 & Jerivá & $\mathrm{S} 23^{\circ} 01^{\prime} 55.1^{\prime \prime}$ & WO $46^{\circ} 58^{\prime} 13.9^{\prime \prime}$ \\
\hline B4P1 & Jerivá & $\mathrm{S} 23^{\circ} 01^{\prime} 55.0^{\prime \prime}$ & WO $46^{\circ} 58^{\prime} 13.9^{\prime \prime}$ \\
\hline B4P2 & Espatódea & $\mathrm{S} 23^{\circ} 01^{\prime} 58.0^{\prime \prime}$ & WO $46^{\circ} 58^{\prime} 15.1^{\prime \prime}$ \\
\hline B4P2 & Jerivá & S $23^{\circ} 01^{\prime} 59.1^{\prime \prime}$ & WO $46^{\circ} 58^{\prime} 15.5^{\prime \prime}$ \\
\hline B4P2 & Jerivá & S $23^{\circ} 01^{\prime} 59.1^{\prime \prime}$ & WO $46^{\circ} 58^{\prime} 15.8^{\prime \prime}$ \\
\hline B4P2 & Jerivá & $\mathrm{S} 23^{\circ} 01^{\prime} 59.0^{\prime \prime}$ & WO $46^{\circ} 58^{\prime} 15.9^{\prime \prime}$ \\
\hline B4P2 & Jerivá & $\mathrm{S} 23^{\circ} 01^{\prime} 59.1^{\prime \prime}$ & WO $46^{\circ} 58^{\prime} 15.8^{\prime \prime}$ \\
\hline B4P2 & Jerivá & $\mathrm{S} 23^{\circ} 01^{\prime} 59.0^{\prime \prime}$ & WO $46^{\circ} 58^{\prime} 15.9^{\prime \prime}$ \\
\hline B4P2 & Jerivá & $\mathrm{S} 23^{\circ} 01^{\prime} 58.9^{\prime \prime}$ & WO $46^{\circ} 58^{\prime} 16.0^{\prime \prime}$ \\
\hline B4P2 & Ipê amarelo & S $23^{\circ} 01^{\prime} 58.6^{\prime \prime}$ & WO $46^{\circ} 58^{\prime} 16.3^{\prime \prime}$ \\
\hline B4P2 & Figueira benjamina & $\mathrm{S} 23^{\circ} 01^{\prime} 58.5^{\prime \prime}$ & WO $46^{\circ} 58^{\prime} 16.1^{\prime \prime}$ \\
\hline B4P2 & Ligustro & $\mathrm{S} 23^{\circ} 01^{\prime} 58,3^{\prime \prime}$ & WO $46^{\circ} 58^{\prime} 15.8^{\prime \prime}$ \\
\hline B4P2 & Ligustro & S $23^{\circ} 01^{\prime} 58.4^{\prime \prime}$ & WO $46^{\circ} 58^{\prime} 15.2^{\prime \prime}$ \\
\hline B4P2 & Ligustro & $\mathrm{S} 23^{\circ} 01^{\prime} 58.4^{\prime \prime}$ & WO $46^{\circ} 58^{\prime} 15.2^{\prime \prime}$ \\
\hline B4P2 & Jerivá & $\mathrm{S} 23^{\circ} 01^{\prime} 58.0^{\prime \prime}$ & WO $46^{\circ} 58^{\prime} 15.2^{\prime \prime}$ \\
\hline B4P2 & Jerivá & S $23^{\circ} 01^{\prime} 57.9^{\prime \prime}$ & WO $46^{\circ} 58^{\prime} 15.3^{\prime \prime}$ \\
\hline $\mathrm{B} 4 \mathrm{P} 2$ & Jerivá & $\mathrm{S} 23^{\circ} 01^{\prime} 57.6^{\prime \prime}$ & WO $46^{\circ} 58^{\prime} 15.5^{\prime \prime}$ \\
\hline
\end{tabular}




\begin{tabular}{|c|c|c|c|}
\hline Praça & Nome Comum & Latitude & Longitude \\
\hline B4P2 & Jerivá & 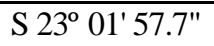 & WO $46^{\circ} 58^{\prime} 15.4^{\prime \prime}$ \\
\hline B4P2 & Jerivá & S $23^{\circ} 01^{\prime} 57.7^{\prime \prime}$ & WO $46^{\circ} 58^{\prime} 15.2^{\prime \prime}$ \\
\hline B4P2 & Jerivá & $\mathrm{S} 23^{\circ} 01^{\prime} 57,7^{\prime \prime}$ & WO $46^{\circ} 58^{\prime} 15.1^{\prime \prime}$ \\
\hline B4P2 & Ligustro & S $23^{\circ} 01^{\prime} 57.9^{\prime \prime}$ & WO $46^{\circ} 58^{\prime} 14.8^{\prime \prime}$ \\
\hline B4P2 & Não identificado & $\mathrm{S} 23^{\circ} 01^{\prime} 57,9^{\prime \prime}$ & WO $46^{\circ} 58^{\prime} 14,7^{\prime \prime}$ \\
\hline B4P2 & Não identificado & $\mathrm{S} 23^{\circ} 01^{\prime} 57.9^{\prime \prime}$ & WO $46^{\circ} 58^{\prime} 14.5^{\prime \prime}$ \\
\hline B4P2 & Não identificado & $\mathrm{S} 23^{\circ} 01^{\prime} 58.0^{\prime \prime}$ & WO $46^{\circ} 58^{\prime} 14.3^{\prime \prime}$ \\
\hline B4P2 & Ligustro & $\mathrm{S} 23^{\circ} 01^{\prime} 58.2^{\prime \prime}$ & WO $46^{\circ} 58^{\prime} 14,5^{\prime \prime}$ \\
\hline B4P2 & Romã & $\mathrm{S} 23^{\circ} 01^{\prime} 58.3^{\prime \prime}$ & WO $46^{\circ} 58^{\prime} 14,6^{\prime \prime}$ \\
\hline B4P2 & Ligustro & $\mathrm{S} 23^{\circ} 01^{\prime} 58.0^{\prime \prime}$ & WO $46^{\circ} 58^{\prime} 14.6^{\prime \prime}$ \\
\hline B4P2 & Pinus & S $23^{\circ} 01^{\prime} 57,7^{\prime \prime}$ & WO $46^{\circ} 58^{\prime} 14,5^{\prime \prime}$ \\
\hline B4P2 & Ligustro & S $23^{\circ} 01^{\prime} 57.4^{\prime \prime}$ & WO $46^{\circ} 58^{\prime} 14.3^{\prime \prime}$ \\
\hline B4P2 & Ligustro & $\mathrm{S} 23^{\circ} 01^{\prime} 57.1$ & WO $46^{\circ} 58^{\prime} 13.4^{\prime \prime}$ \\
\hline B4P2 & Ligustro & S $23^{\circ} 01^{\prime} 57.2^{\prime \prime}$ & WO $46^{\circ} 58^{\prime} 13.4^{\prime \prime}$ \\
\hline B4P2 & Ligustro & $\mathrm{S} 23^{\circ} 01^{\prime} 57.2^{\prime \prime}$ & WO $46^{\circ} 58^{\prime} 13.4^{\prime \prime}$ \\
\hline B4P2 & Não identificado & S $23^{\circ} 01^{\prime} 57.4^{\prime \prime}$ & WO $46^{\circ} 58^{\prime} 13.3^{\prime \prime}$ \\
\hline B4P2 & Ligustro & S $23^{\circ} 01^{\prime} 57.6^{\prime \prime}$ & WO $46^{\circ} 58^{\prime} 13.7^{\prime \prime}$ \\
\hline B4P2 & Ligustro & S $23^{\circ} 01^{\prime} 57.6^{\prime \prime}$ & WO $46^{\circ} 58^{\prime} 13.7^{\prime \prime}$ \\
\hline B5P1 & Jerivá & $\mathrm{S} 23^{\circ} 01^{\prime} 45.6^{\prime \prime}$ & WO $46^{\circ} 58^{\prime} 27.3^{\prime \prime}$ \\
\hline B5P1 & Jerivá & $\mathrm{S} 23^{\circ} 01^{\prime} 45.5^{\prime \prime}$ & WO $46^{\circ} 58^{\prime} 27.0^{\prime \prime}$ \\
\hline B5P1 & Jerivá & $\mathrm{S} 23^{\circ} 01^{\prime} 45.4^{\prime \prime}$ & WO $46^{\circ} 58^{\prime} 26.9^{\prime \prime}$ \\
\hline B5P1 & Jerivá & $\mathrm{S} 23^{\circ} 01^{\prime} 45.4^{\prime \prime}$ & WO $46^{\circ} 58^{\prime} 26.8^{\prime \prime}$ \\
\hline B5P1 & Jerivá & $\mathrm{S} 23^{\circ} 01^{\prime} 45.4^{\prime \prime}$ & WO $46^{\circ} 58^{\prime} 26.7^{\prime \prime}$ \\
\hline B5P1 & Jerivá & $\mathrm{S} 23^{\circ} 01^{\prime} 45.4^{\prime \prime}$ & WO $46^{\circ} 58^{\prime} 26.5^{\prime \prime}$ \\
\hline B5P1 & Coração de negro & $\mathrm{S} 23^{\circ} 01^{\prime} 45.2^{\prime \prime}$ & WO $46^{\circ} 58^{\prime} 26.6^{\prime \prime}$ \\
\hline B5P1 & Jerivá & $\mathrm{S} 23^{\circ} 01^{\prime} 45.3^{\prime \prime}$ & WO $46^{\circ} 58^{\prime} 27.0^{\prime \prime}$ \\
\hline B5P1 & Jerivá & $\mathrm{S} 23^{\circ} 01^{\prime} 45.2^{\prime \prime}$ & WO $46^{\circ} 58^{\prime} 27.0^{\prime \prime}$ \\
\hline B5P1 & Jerivá & $\mathrm{S} 23^{\circ} 01^{\prime} 45.3^{\prime \prime}$ & WO $46^{\circ} 58^{\prime} 26.9^{\prime \prime}$ \\
\hline B5P1 & Jerivá & $\mathrm{S} 23^{\circ} 01^{\prime} 46.0^{\prime \prime}$ & WO $46^{\circ} 58^{\prime} 26.5^{\prime \prime}$ \\
\hline B5P1 & Jerivá & $\mathrm{S} 23^{\circ} 01^{\prime} 45.9^{\prime \prime}$ & WO $46^{\circ} 58^{\prime} 26.5^{\prime \prime}$ \\
\hline B5P1 & Jerivá & $\mathrm{S} 23^{\circ} 01^{\prime} 45.9^{\prime \prime}$ & WO $46^{\circ} 58^{\prime} 26.4^{\prime \prime}$ \\
\hline B5P1 & Jerivá & $\mathrm{S} 23^{\circ} 01^{\prime} 45.8^{\prime \prime}$ & WO $46^{\circ} 58^{\prime} 26.4^{\prime \prime}$ \\
\hline B5P1 & Jerivá & $\mathrm{S} 23^{\circ} 01^{\prime} 45.8^{\prime \prime}$ & WO $46^{\circ} 58^{\prime} 26.3^{\prime \prime}$ \\
\hline B5P1 & Coração de negro & $\mathrm{S} 23^{\circ} 01^{\prime} 45.7^{\prime \prime}$ & WO $46^{\circ} 58^{\prime} 26.4^{\prime \prime}$ \\
\hline B5P1 & Jerivá & $\mathrm{S} 23^{\circ} 01^{\prime} 45.8^{\prime \prime}$ & WO $46^{\circ} 58^{\prime} 26.5^{\prime \prime}$ \\
\hline B5P1 & Jerivá & $\mathrm{S} 23^{\circ} 01^{\prime} 45.6^{\prime \prime}$ & WO $46^{\circ} 58^{\prime} 26.4^{\prime \prime}$ \\
\hline B5P1 & Jerivá & $\mathrm{S} 23^{\circ} 01^{\prime} 45.6^{\prime \prime}$ & WO $46^{\circ} 58^{\prime} 26.5^{\prime \prime}$ \\
\hline B5P1 & Jerivá & $\mathrm{S} 23^{\circ} 01^{\prime} 45.8^{\prime \prime}$ & WO $46^{\circ} 58^{\prime} 26.5^{\prime \prime}$ \\
\hline B5P1 & Figueira benjamina & $\mathrm{S} 23^{\circ} 01^{\prime} 45.7^{\prime \prime}$ & WO $46^{\circ} 58^{\prime} 27.0^{\prime \prime}$ \\
\hline B5P1 & Figueira benjamina & $\mathrm{S} 23^{\circ} 01^{\prime} 45.8^{\prime \prime}$ & WO $46^{\circ} 58^{\prime} 27.2^{\prime \prime}$ \\
\hline B5P1 & Figueira benjamina & $\mathrm{S} 23^{\circ} 01^{\prime} 46.3^{\prime \prime}$ & WO $46^{\circ} 58^{\prime} 26.8^{\prime \prime}$ \\
\hline B5P1 & Figueira benjamina & $\mathrm{S} 23^{\circ} 01^{\prime} 46.3^{\prime \prime}$ & WO $46^{\circ} 58^{\prime} 26.8^{\prime \prime}$ \\
\hline B5P1 & Figueira benjamina & $\mathrm{S} 23^{\circ} 01^{\prime} 46.3^{\prime \prime}$ & WO $46^{\circ} 58^{\prime} 26.8^{\prime \prime}$ \\
\hline B5P1 & Figueira benjamina & $\mathrm{S} 23^{\circ} 01^{\prime} 46.3^{\prime \prime}$ & WO $46^{\circ} 58^{\prime} 27.5^{\prime \prime}$ \\
\hline B5P1 & Palmeira triangular & $\mathrm{S} 23^{\circ} 01^{\prime} 46.6^{\prime \prime}$ & WO $46^{\circ} 58^{\prime} 27.2^{\prime \prime}$ \\
\hline B5P1 & Palmeira triangular & $\mathrm{S} 23^{\circ} 01^{\prime} 46.4^{\prime \prime}$ & WO $46^{\circ} 58^{\prime} 27.2^{\prime \prime}$ \\
\hline B5P1 & Palmeira triangular & $\mathrm{S} 23^{\circ} 01^{\prime} 46.1^{\prime \prime}$ & WO $46^{\circ} 58^{\prime} 27.3^{\prime \prime}$ \\
\hline B5P1 & Palmeira triangular & $S 23^{\circ} 01^{\prime} 45.6^{\prime \prime}$ & WO $46^{\circ} 58^{\prime} 28.1^{\prime \prime}$ \\
\hline B5P1 & Palmeira triangular & $\mathrm{S} 23^{\circ} 01^{\prime} 45.8^{\prime \prime}$ & WO $46^{\circ} 58^{\prime} 28.0^{\prime \prime}$ \\
\hline B5P1 & Palmeira triangular & $\mathrm{S} 23^{\circ} 01^{\prime} 46.1^{\prime \prime}$ & WO $46^{\circ} 58^{\prime} 27.5^{\prime \prime}$ \\
\hline
\end{tabular}




\begin{tabular}{|c|c|c|c|}
\hline Praça & Nome Comum & Latitude & Longitude \\
\hline $\mathrm{B} 5 \mathrm{P} 1$ & Palmeira triangular & $\mathrm{S} 23^{\circ} 01^{\prime} 45.9^{\prime \prime}$ & WO $46^{\circ} 58^{\prime} 27.5^{\prime \prime}$ \\
\hline B5P1 & Palmeira triangular & $\mathrm{S} 23^{\circ} 01^{\prime} 46.1^{\prime \prime}$ & WO $46^{\circ} 58^{\prime} 27.6^{\prime \prime}$ \\
\hline B5P1 & Palmeira triangular & $\mathrm{S} 23^{\circ} 01^{\prime} 46.0^{\prime \prime}$ & WO $46^{\circ} 58^{\prime} 27.7^{\prime \prime}$ \\
\hline B5P1 & Palmeira triangular & $\mathrm{S} 23^{\circ} 01^{\prime} 45.9^{\prime \prime}$ & WO $46^{\circ} 58^{\prime} 27.7^{\prime \prime}$ \\
\hline B5P1 & Palmeira triangular & $\mathrm{S} 23^{\circ} 01^{\prime} 46.0^{\prime \prime}$ & WO $46^{\circ} 58^{\prime} 27.7^{\prime \prime}$ \\
\hline B5P1 & Palmeira triangular & $\mathrm{S} 23^{\circ} 01^{\prime} 46.0^{\prime \prime}$ & WO $46^{\circ} 58^{\prime} 27.8^{\prime \prime}$ \\
\hline B5P1 & Palmeira triangular & $\mathrm{S} 23^{\circ} 01^{\prime} 45.8^{\prime \prime}$ & WO $46^{\circ} 58^{\prime} 27.9^{\prime \prime}$ \\
\hline B5P1 & Palmeira triangular & $\mathrm{S} 23^{\circ} 01^{\prime} 45.9^{\prime \prime}$ & WO $46^{\circ} 58^{\prime} 28.0^{\prime \prime}$ \\
\hline B5P1 & Palmeira triangular & $\mathrm{S} 23^{\circ} 01^{\prime} 45.8^{\prime \prime}$ & WO $46^{\circ} 58^{\prime} 28.0^{\prime \prime}$ \\
\hline B5P1 & Palmeira triangular & $\mathrm{S} 23^{\circ} 01^{\prime} 45.7^{\prime \prime}$ & WO $46^{\circ} 58^{\prime} 27.7^{\prime \prime}$ \\
\hline B5P1 & Jerivá & $\mathrm{S} 23^{\circ} 01^{\prime} 46.6^{\prime \prime}$ & WO $46^{\circ} 58^{\prime} 29.3^{\prime \prime}$ \\
\hline B5P1 & Não identificado & $\mathrm{S} 23^{\circ} 01^{\prime} 46.5^{\prime \prime}$ & WO $46^{\circ} 58^{\prime} 29.1^{\prime \prime}$ \\
\hline B5P1 & Jerivá & $\mathrm{S} 23^{\circ} 01^{\prime} 46.5^{\prime \prime}$ & WO $46^{\circ} 58^{\prime} 29.1^{\prime \prime}$ \\
\hline B5P1 & Jerivá & $\mathrm{S} 23^{\circ} 01^{\prime} 46.5^{\prime \prime}$ & WO $46^{\circ} 58^{\prime} 29.1^{\prime \prime}$ \\
\hline B5P1 & Jerivá & $\mathrm{S} 23^{\circ} 01^{\prime} 46.9^{\prime \prime}$ & WO $46^{\circ} 58^{\prime} 29.1^{\prime \prime}$ \\
\hline B5P1 & Jerivá & $\mathrm{S} 23^{\circ} 01^{\prime} 47.1^{\prime \prime}$ & WO $46^{\circ} 58^{\prime} 29.3^{\prime \prime}$ \\
\hline B5P1 & Palmeira seafortia & $\mathrm{S} 23^{\circ} 01^{\prime} 46.6^{\prime \prime}$ & WO $46^{\circ} 58^{\prime} 29.1^{\prime \prime}$ \\
\hline B5P1 & Palmeira seafortia & $\mathrm{S} 23^{\circ} 01^{\prime} 47.3^{\prime \prime}$ & WO $46^{\circ} 58^{\prime} 28.8^{\prime \prime}$ \\
\hline B5P1 & Palmeira seafortia & $\mathrm{S} 23^{\circ} 01^{\prime} 47.0^{\prime \prime}$ & WO $46^{\circ} 58^{\prime} 28.8^{\prime \prime}$ \\
\hline B5P1 & Palmeira seafortia & $\mathrm{S} 23^{\circ} 01^{\prime} 47.1^{\prime \prime}$ & WO $46^{\circ} 58^{\prime} 28.6^{\prime \prime}$ \\
\hline B5P1 & Jerivá & $\mathrm{S} 23^{\circ} 01^{\prime} 47.1^{\prime \prime}$ & WO $46^{\circ} 58^{\prime} 28.9^{\prime \prime}$ \\
\hline B5P1 & Jerivá & $\mathrm{S} 23^{\circ} 01^{\prime} 47.3^{\prime \prime}$ & WO $46^{\circ} 58^{\prime} 28.8^{\prime \prime}$ \\
\hline B5P1 & Jerivá & $\mathrm{S} 23^{\circ} 01^{\prime} 47.3^{\prime \prime}$ & WO $46^{\circ} 58^{\prime} 28.9^{\prime \prime}$ \\
\hline B5P1 & Jerivá & $\mathrm{S} 23^{\circ} 01^{\prime} 47.1^{\prime \prime}$ & WO $46^{\circ} 58^{\prime} 28.7^{\prime \prime}$ \\
\hline B5P1 & Coração de negro & $\mathrm{S} 23^{\circ} 01^{\prime} 47.2^{\prime \prime}$ & WO $46^{\circ} 58^{\prime} 28.8^{\prime \prime}$ \\
\hline B5P1 & Jerivá & $\mathrm{S} 23^{\circ} 01^{\prime} 47.1^{\prime \prime}$ & WO $46^{\circ} 58^{\prime} 29.0^{\prime \prime}$ \\
\hline B5P1 & Sibipiruna & $\mathrm{S} 23^{\circ} 01^{\prime} 46.4^{\prime \prime}$ & WO $46^{\circ} 58^{\prime} 27.9^{\prime \prime}$ \\
\hline B5P1 & Sibipiruna & $\mathrm{S} 23^{\circ} 01^{\prime} 46.6^{\prime \prime}$ & WO $46^{\circ} 58^{\prime} 29.2^{\prime \prime}$ \\
\hline B5P1 & Jerivá & $\mathrm{S} 23^{\circ} 01^{\prime} 45.7^{\prime \prime}$ & WO $46^{\circ} 58^{\prime} 28.0^{\prime \prime}$ \\
\hline B5P1 & Jerivá & $\mathrm{S} 23^{\circ} 01^{\prime} 46.0^{\prime \prime}$ & WO $46^{\circ} 58^{\prime} 28.5^{\prime \prime}$ \\
\hline B5P2 & Pinus & S $23^{\circ} 01^{\prime} 55.4^{\prime \prime}$ & WO $46^{\circ} 58^{\prime} 34.2^{\prime \prime}$ \\
\hline B5P2 & Pinus & $\mathrm{S} 23^{\circ} 01^{\prime} 55.3^{\prime \prime}$ & WO $46^{\circ} 58^{\prime} 34.2^{\prime \prime}$ \\
\hline B5P2 & Pinus & $\mathrm{S} 23^{\circ} 01^{\prime} 55.0^{\prime \prime}$ & WO $46^{\circ} 58^{\prime} 34.2^{\prime \prime}$ \\
\hline B5P2 & Pinus & $\mathrm{S} 23^{\circ} 01^{\prime} 54.9^{\prime \prime}$ & WO $46^{\circ} 58^{\prime} 34.0^{\prime \prime}$ \\
\hline B5P2 & Pinus & $\mathrm{S} 23^{\circ} 01^{\prime} 55.0^{\prime \prime}$ & WO $46^{\circ} 58^{\prime} 33.7^{\prime \prime}$ \\
\hline B5P2 & Pinus & $\mathrm{S} 23^{\circ} 01^{\prime} 55.1^{\prime \prime}$ & WO $46^{\circ} 58^{\prime} 33.5^{\prime \prime}$ \\
\hline B5P2 & Espatódea & $\mathrm{S} 23^{\circ} 01^{\prime} 54.8^{\prime \prime}$ & WO $46^{\circ} 58^{\prime} 33.4^{\prime \prime}$ \\
\hline B5P2 & Espatódea & S $23^{\circ} 01^{\prime} 54.6^{\prime \prime}$ & WO $46^{\circ} 58^{\prime} 33.5^{\prime \prime}$ \\
\hline B5P2 & Pinus & $\mathrm{S} 23^{\circ} 01^{\prime} 54.5^{\prime \prime}$ & WO $46^{\circ} 58^{\prime} 33.5^{\prime \prime}$ \\
\hline B5P2 & Espatódea & $\mathrm{S} 23^{\circ} 01^{\prime} 54.3^{\prime \prime}$ & WO $46^{\circ} 58^{\prime} 33.8^{\prime \prime}$ \\
\hline B5P2 & Espatódea & S $23^{\circ} 01^{\prime} 54.2^{\prime \prime}$ & WO $46^{\circ} 58^{\prime} 32.7^{\prime \prime}$ \\
\hline B5P2 & Espatódea & $\mathrm{S} 23^{\circ} 01^{\prime} 54.5^{\prime \prime}$ & WO $46^{\circ} 58^{\prime} 32.5^{\prime \prime}$ \\
\hline B5P2 & Espatódea & S $23^{\circ} 01^{\prime} 54.4^{\prime \prime}$ & WO $46^{\circ} 58^{\prime} 32.5^{\prime \prime}$ \\
\hline B5P2 & Espatódea & $\mathrm{S} 23^{\circ} 01^{\prime} 54.2^{\prime \prime}$ & WO $46^{\circ} 58^{\prime} 33.4^{\prime \prime}$ \\
\hline B5P2 & Pinus & $\mathrm{S} 23^{\circ} 01^{\prime} 54.1^{\prime \prime}$ & WO $46^{\circ} 58^{\prime} 33.0^{\prime \prime}$ \\
\hline B5P2 & Espatódea & S $23^{\circ} 01^{\prime} 54.4^{\prime \prime}$ & WO $46^{\circ} 58^{\prime} 32.8^{\prime \prime}$ \\
\hline B5P2 & Espatódea & $\mathrm{S} 23^{\circ} 01^{\prime} 54.6^{\prime \prime}$ & WO $46^{\circ} 58^{\prime} 32.8^{\prime \prime}$ \\
\hline B5P2 & Espatódea & $\mathrm{S} 23^{\circ} 01^{\prime} 54.2^{\prime \prime}$ & WO $46^{\circ} 58^{\prime} 33.0^{\prime \prime}$ \\
\hline B5P2 & Não identificado & $\mathrm{S} 23^{\circ} 01^{\prime} 54.3^{\prime \prime}$ & WO $46^{\circ} 58^{\prime} 32.9^{\prime \prime}$ \\
\hline $\mathrm{B} 5 \mathrm{P} 2$ & Espatódea & $\mathrm{S} 23^{\circ} 01^{\prime} 54.2^{\prime \prime}$ & WO $46^{\circ} 58^{\prime} 32.8^{\prime \prime}$ \\
\hline
\end{tabular}




\begin{tabular}{|c|c|c|c|}
\hline Praça & Nome Comum & Latitude & Longitude \\
\hline $\mathrm{B} 5 \mathrm{P} 2$ & Espatódea & $\mathrm{S} \mathrm{23}^{\circ} 01^{\prime} 54.3^{\prime \prime}$ & WO $46^{\circ} 58^{\prime} 32.8^{\prime \prime}$ \\
\hline B5P2 & Pinus & $\mathrm{S} 23^{\circ} 01^{\prime} 54.3^{\prime \prime}$ & WO $46^{\circ} 58^{\prime} 32.8^{\prime \prime}$ \\
\hline B5P2 & Espatódea & $\mathrm{S} 23^{\circ} 01^{\prime} 54.1^{\prime \prime}$ & WO $46^{\circ} 58^{\prime} 32.8^{\prime \prime}$ \\
\hline B5P2 & Espatódea & $\mathrm{S} 23^{\circ} 01^{\prime} 54.0^{\prime \prime}$ & WO $46^{\circ} 58^{\prime} 32.8^{\prime \prime}$ \\
\hline $\mathrm{B} 5 \mathrm{P} 2$ & Pinus & $\mathrm{S} 23^{\circ} 01^{\prime} 54.3^{\prime \prime}$ & WO $46^{\circ} 58^{\prime} 32.8^{\prime \prime}$ \\
\hline B5P2 & Espatódea & $\mathrm{S} 23^{\circ} 01^{\prime} 54.0^{\prime \prime}$ & WO $46^{\circ} 58^{\prime} 32.3^{\prime \prime}$ \\
\hline B5P2 & Espatódea & S $23^{\circ} 01^{\prime} 53.6^{\prime \prime}$ & WO $46^{\circ} 58^{\prime} 32.6^{\prime \prime}$ \\
\hline B5P2 & Espatódea & $\mathrm{S} 23^{\circ} 01^{\prime} 54.0^{\prime \prime}$ & WO $46^{\circ} 58^{\prime} 32.4^{\prime \prime}$ \\
\hline B5P2 & Espatódea & $\mathrm{S} 23^{\circ} 01^{\prime} 54.0^{\prime \prime}$ & WO $46^{\circ} 58^{\prime} 32.6^{\prime \prime}$ \\
\hline B5P2 & Espatódea & $\mathrm{S} 23^{\circ} 01^{\prime} 54.0^{\prime \prime}$ & WO $46^{\circ} 58^{\prime} 32.3^{\prime \prime}$ \\
\hline B5P2 & Pinus & $\mathrm{S} 23^{\circ} 01^{\prime} 54.1^{\prime \prime}$ & WO $46^{\circ} 58^{\prime} 32.1^{\prime \prime}$ \\
\hline B5P2 & Pinus & $\mathrm{S} 23^{\circ} 01^{\prime} 54.3^{\prime \prime}$ & WO $46^{\circ} 58^{\prime} 32,7^{\prime \prime}$ \\
\hline B5P2 & Espatódea & $\mathrm{S} 23^{\circ} 01^{\prime} 53.7^{\prime \prime}$ & WO $46^{\circ} 58^{\prime} 32.8^{\prime \prime}$ \\
\hline B5P2 & Grevília & $\mathrm{S} 23^{\circ} 01^{\prime} 54.5^{\prime \prime}$ & WO $46^{\circ} 58^{\prime} 32.7^{\prime \prime}$ \\
\hline B5P2 & Pinus & $\mathrm{S} 23^{\circ} 01^{\prime} 54.6^{\prime \prime}$ & WO $46^{\circ} 58^{\prime} 32.5^{\prime \prime}$ \\
\hline B5P2 & Pinus & $\mathrm{S} 23^{\circ} 01^{\prime} 54.7^{\prime \prime}$ & WO $46^{\circ} 58^{\prime} 32.4^{\prime \prime}$ \\
\hline B5P2 & Pinus & $\mathrm{S} 23^{\circ} 01^{\prime} 54.9^{\prime \prime}$ & WO $46^{\circ} 58^{\prime} 33.1^{\prime \prime}$ \\
\hline B5P2 & Pinus & $\mathrm{S} 23^{\circ} 01^{\prime} 54.8^{\prime \prime}$ & WO $46^{\circ} 58^{\prime} 33.0^{\prime \prime}$ \\
\hline B5P2 & Não identificado & S $23^{\circ} 01^{\prime} 54.6^{\prime \prime}$ & WO $46^{\circ} 58^{\prime} 32.9^{\prime \prime}$ \\
\hline B5P2 & Pau Brasil & $\mathrm{S} 23^{\circ} 01^{\prime} 54.7^{\prime \prime}$ & WO $46^{\circ} 58^{\prime} 32.8^{\prime \prime}$ \\
\hline B5P2 & Cinamomo & $\mathrm{S} 23^{\circ} 01^{\prime} 54.9^{\prime \prime}$ & WO $46^{\circ} 58^{\prime} 33.0^{\prime \prime}$ \\
\hline B5P2 & Cinamomo & $\mathrm{S} 23^{\circ} 01^{\prime} 55.0^{\prime \prime}$ & WO $46^{\circ} 58^{\prime} 33.1^{\prime \prime}$ \\
\hline B5P2 & Pau Brasil & S $23^{\circ} 01^{\prime} 55.4^{\prime \prime}$ & WO $46^{\circ} 58^{\prime} 33.2^{\prime \prime}$ \\
\hline B5P2 & Aroeira & S $23^{\circ} 01^{\prime} 55.4^{\prime \prime}$ & WO $46^{\circ} 58^{\prime} 33.2^{\prime \prime}$ \\
\hline B5P2 & Canela & $\mathrm{S} 23^{\circ} 01^{\prime} 55.5^{\prime \prime}$ & WO $46^{\circ} 58^{\prime} 34.1^{\prime \prime}$ \\
\hline B5P2 & Pau Brasil & S $23^{\circ} 01^{\prime} 55.6^{\prime \prime}$ & WO $46^{\circ} 58^{\prime} 34.1^{\prime \prime}$ \\
\hline B5P2 & Palmeira seafortia & $\mathrm{S} 23^{\circ} 01^{\prime} 56.0^{\prime \prime}$ & WO $46^{\circ} 58^{\prime} 33.9^{\prime \prime}$ \\
\hline B5P2 & Palmeira seafortia & $\mathrm{S} 23^{\circ} 01^{\prime} 56.2^{\prime \prime}$ & WO $46^{\circ} 58^{\prime} 33.7^{\prime \prime}$ \\
\hline B5P2 & Palmeira seafortia & $\mathrm{S} 23^{\circ} 01^{\prime} 56.1^{\prime \prime}$ & WO $46^{\circ} 58^{\prime} 33.7^{\prime \prime}$ \\
\hline B5P2 & Palmeira seafortia & $\mathrm{S} 23^{\circ} 01^{\prime} 56.1^{\prime \prime}$ & WO $46^{\circ} 58^{\prime} 33.6^{\prime \prime}$ \\
\hline B5P2 & Palmeira seafortia & $\mathrm{S} 23^{\circ} 01^{\prime} 55.5^{\prime \prime}$ & WO $46^{\circ} 58^{\prime} 33.7^{\prime \prime}$ \\
\hline B5P2 & Palmeira seafortia & $\mathrm{S} 23^{\circ} 01^{\prime} 56.1^{\prime \prime}$ & WO $46^{\circ} 58^{\prime} 33.5^{\prime \prime}$ \\
\hline B5P2 & Palmeira seafortia & S $23^{\circ} 01^{\prime} 56.1^{\prime \prime}$ & WO $46^{\circ} 58^{\prime} 33.5^{\prime \prime}$ \\
\hline B5P2 & Palmeira seafortia & $\mathrm{S} 23^{\circ} 01^{\prime} 56.2^{\prime \prime}$ & WO $46^{\circ} 58^{\prime} 33.6^{\prime \prime}$ \\
\hline B5P2 & Palmeira seafortia & $\mathrm{S} 23^{\circ} 01^{\prime} 56.3^{\prime \prime}$ & WO $46^{\circ} 58^{\prime} 33.6^{\prime \prime}$ \\
\hline B5P2 & Palmeira seafortia & S $23^{\circ} 01^{\prime} 56.4^{\prime \prime}$ & WO $46^{\circ} 58^{\prime} 33.3^{\prime \prime}$ \\
\hline B5P2 & Palmeira seafortia & $\mathrm{S} 23^{\circ} 01^{\prime} 56.5^{\prime \prime}$ & WO $46^{\circ} 58^{\prime} 33.3^{\prime \prime}$ \\
\hline B5P2 & Jerivá & $\mathrm{S} 23^{\circ} 01^{\prime} 57.0^{\prime \prime}$ & WO $46^{\circ} 58^{\prime} 33.1^{\prime \prime}$ \\
\hline B5P2 & Jerivá & $\mathrm{S} 23^{\circ} 01^{\prime} 57.1^{\prime \prime}$ & WO $46^{\circ} 58^{\prime} 32.9^{\prime \prime}$ \\
\hline B5P2 & Jerivá & $\mathrm{S} 23^{\circ} 01^{\prime} 57.1^{\prime \prime}$ & WO $46^{\circ} 58^{\prime} 33.2^{\prime \prime}$ \\
\hline B5P2 & Jerivá & $\mathrm{S} 23^{\circ} 01^{\prime} 57.1^{\prime \prime}$ & WO $46^{\circ} 58^{\prime} 33.1^{\prime \prime}$ \\
\hline B5P2 & Jerivá & $\mathrm{S} 23^{\circ} 01^{\prime} 57.0^{\prime \prime}$ & WO $46^{\circ} 58^{\prime} 32.9^{\prime \prime}$ \\
\hline B5P2 & Jerivá & $\mathrm{S} 23^{\circ} 01^{\prime} 57.0^{\prime \prime}$ & WO $46^{\circ} 58^{\prime} 32.7^{\prime \prime}$ \\
\hline B5P2 & Jerivá & $\mathrm{S} 23^{\circ} 01^{\prime} 57.3^{\prime \prime}$ & WO $46^{\circ} 58^{\prime} 32.9^{\prime \prime}$ \\
\hline B5P2 & Jerivá & S $23^{\circ} 01^{\prime} 57.4^{\prime \prime}$ & WO $46^{\circ} 58^{\prime} 32.8^{\prime \prime}$ \\
\hline B5P2 & Palmeira seafortia & $\mathrm{S} 23^{\circ} 01^{\prime} 57.4^{\prime \prime}$ & WO $46^{\circ} 58^{\prime} 32.7^{\prime \prime}$ \\
\hline B5P2 & Jerivá & S $23^{\circ} 01^{\prime} 57.4^{\prime \prime}$ & WO $46^{\circ} 58^{\prime} 32.7^{\prime \prime}$ \\
\hline B5P2 & Jerivá & $\mathrm{S} 23^{\circ} 01^{\prime} 57.5^{\prime \prime}$ & WO $46^{\circ} 58^{\prime} 32.8^{\prime \prime}$ \\
\hline B5P2 & Jerivá & $\mathrm{S} 23^{\circ} 01^{\prime} 57.6^{\prime \prime}$ & WO $46^{\circ} 58^{\prime} 33.0^{\prime \prime}$ \\
\hline B5P2 & Jerivá & $\mathrm{S} 23^{\circ} 01^{\prime} 57.4^{\prime \prime}$ & WO $46^{\circ} 58^{\prime} 32.8^{\prime \prime}$ \\
\hline
\end{tabular}




\begin{tabular}{|c|c|c|c|}
\hline Praça & Nome Comum & Latitude & Longitude \\
\hline B5P2 & Jerivá & S $23^{\circ} 01^{\prime} 57.3^{\prime \prime}$ & WO $46^{\circ} 58^{\prime} 32.8^{\prime \prime}$ \\
\hline B5P2 & Jerivá & S $23^{\circ} 01^{\prime} 57.4^{\prime \prime}$ & WO $46^{\circ} 58^{\prime} 32.9^{\prime \prime}$ \\
\hline B5P2 & Jerivá & S $23^{\circ} 01^{\prime} 57.5^{\prime \prime}$ & WO $46^{\circ} 58^{\prime} 32.9^{\prime \prime}$ \\
\hline B5P2 & Jerivá & S $23^{\circ} 01^{\prime} 57,2^{\prime \prime}$ & WO $46^{\circ} 58^{\prime} 32.4^{\prime \prime}$ \\
\hline B5P2 & Jerivá & S $23^{\circ} 01^{\prime} 57.2^{\prime \prime}$ & WO $46^{\circ} 58^{\prime} 32.3^{\prime \prime}$ \\
\hline B5P2 & Jerivá & S $23^{\circ} 01^{\prime} 57.0^{\prime \prime}$ & WO $46^{\circ} 58^{\prime} 33.2^{\prime \prime}$ \\
\hline B5P2 & Jerivá & S $23^{\circ} 01^{\prime} 56.8^{\prime \prime}$ & WO $46^{\circ} 58^{\prime} 32.0^{\prime \prime}$ \\
\hline B5P2 & Jerivá & S $23^{\circ} 01^{\prime} 56.7^{\prime \prime}$ & WO $46^{\circ} 58^{\prime} 32.0^{\prime \prime}$ \\
\hline B5P2 & Jerivá & S $23^{\circ} 01^{\prime} 56.7^{\prime \prime}$ & WO $46^{\circ} 58^{\prime} 32.1^{\prime \prime}$ \\
\hline B5P2 & Jerivá & S $23^{\circ} 01^{\prime} 56.1^{\prime \prime}$ & WO $46^{\circ} 58^{\prime} 31.4^{\prime \prime}$ \\
\hline B5P2 & Jerivá & S $23^{\circ} 01^{\prime} 55.9^{\prime \prime}$ & WO $46^{\circ} 58^{\prime} 31.1^{\prime \prime}$ \\
\hline B5P2 & Jerivá & S $23^{\circ} 01^{\prime} 56.0^{\prime \prime}$ & WO $46^{\circ} 58^{\prime} 31.3^{\prime \prime}$ \\
\hline B5P2 & Jerivá & S $23^{\circ} 01^{\prime} 56.0^{\prime \prime}$ & WO $46^{\circ} 58^{\prime} 31.3^{\prime \prime}$ \\
\hline B5P2 & Jerivá & $\mathrm{S} 23^{\circ} 01^{\prime} 55.9^{\prime \prime}$ & WO $46^{\circ} 58^{\prime} 31.1^{\prime \prime}$ \\
\hline B5P2 & Jerivá & $\mathrm{S} 23^{\circ} 01^{\prime} 55.5^{\prime \prime}$ & WO $46^{\circ} 58^{\prime} 31.3^{\prime \prime}$ \\
\hline B5P2 & Jerivá & $\mathrm{S} 23^{\circ} 01^{\prime} 55.6^{\prime \prime}$ & WO $46^{\circ} 58^{\prime} 31.4^{\prime \prime}$ \\
\hline B5P2 & Jerivá & $\mathrm{S} 23^{\circ} 01^{\prime} 55.3^{\prime \prime}$ & WO $46^{\circ} 58^{\prime} 31.5^{\prime \prime}$ \\
\hline B5P2 & Jerivá & S $23^{\circ} 01^{\prime} 55.6^{\prime \prime}$ & WO $46^{\circ} 58^{\prime} 31.5^{\prime \prime}$ \\
\hline B5P2 & Jerivá & S $23^{\circ} 01^{\prime} 55.5^{\prime \prime}$ & WO $46^{\circ} 58^{\prime} 31.5^{\prime \prime}$ \\
\hline B5P2 & Jerivá & S $23^{\circ} 01^{\prime} 55.3^{\prime \prime}$ & WO $46^{\circ} 58^{\prime} 31.8^{\prime \prime}$ \\
\hline B5P2 & Jerivá & S $23^{\circ} 01^{\prime} 55.3^{\prime \prime}$ & WO $46^{\circ} 58^{\prime} 32.0^{\prime \prime}$ \\
\hline B5P2 & Jerivá & S $23^{\circ} 01^{\prime} 55.3^{\prime \prime}$ & WO $46^{\circ} 58^{\prime} 31.8^{\prime \prime}$ \\
\hline B5P2 & Jerivá & S $23^{\circ} 01^{\prime} 55.9^{\prime \prime}$ & WO $46^{\circ} 58^{\prime} 32.5^{\prime \prime}$ \\
\hline B5P2 & Jerivá & S $23^{\circ} 01^{\prime} 55.1^{\prime \prime}$ & WO $46^{\circ} 58^{\prime} 31.6^{\prime \prime}$ \\
\hline B5P2 & Jerivá & S $23^{\circ} 01^{\prime} 55.1^{\prime \prime}$ & WO $46^{\circ} 58^{\prime} 31.8^{\prime \prime}$ \\
\hline B5P2 & Jerivá & S $23^{\circ} 01^{\prime} 56.3^{\prime \prime}$ & WO $46^{\circ} 58^{\prime} 32.4^{\prime \prime}$ \\
\hline B5P2 & Jerivá & S $23^{\circ} 01^{\prime} 56.3^{\prime \prime}$ & WO $46^{\circ} 58^{\prime} 32.3^{\prime \prime}$ \\
\hline B5P2 & Jerivá & $\mathrm{S} 23^{\circ} 01^{\prime} 56.3^{\prime \prime}$ & WO $46^{\circ} 58^{\prime} 32.3^{\prime \prime}$ \\
\hline B5P2 & Jerivá & $\mathrm{S} 23^{\circ} 01^{\prime} 56.1^{\prime \prime}$ & WO $46^{\circ} 58^{\prime} 32.5^{\prime \prime}$ \\
\hline B5P2 & Jerivá & $\mathrm{S} 23^{\circ} 01^{\prime} 56.0^{\prime \prime}$ & WO $46^{\circ} 58^{\prime} 32.4^{\prime \prime}$ \\
\hline B5P2 & Jerivá & $\mathrm{S} 23^{\circ} 01^{\prime} 56.1^{\prime \prime}$ & WO $46^{\circ} 58^{\prime} 32.4^{\prime \prime}$ \\
\hline B5P2 & Jerivá & $\mathrm{S} 23^{\circ} 01^{\prime} 56.2^{\prime \prime}$ & WO $46^{\circ} 58^{\prime} 32.3^{\prime \prime}$ \\
\hline B5P2 & Espatódea & $\mathrm{S} 23^{\circ} 01^{\prime} 53.4^{\prime \prime}$ & WO $46^{\circ} 58^{\prime} 31.9^{\prime \prime}$ \\
\hline B5P2 & Pinus & $\mathrm{S} 23^{\circ} 01^{\prime} 52.4^{\prime \prime}$ & WO $46^{\circ} 58^{\prime} 32.0^{\prime \prime}$ \\
\hline B5P2 & Pinus & $\mathrm{S} 23^{\circ} 01^{\prime} 53.5^{\prime \prime}$ & WO $46^{\circ} 58^{\prime} 32.0^{\prime \prime}$ \\
\hline B5P2 & Pinus & $\mathrm{S} 23^{\circ} 01^{\prime} 53.5^{\prime \prime}$ & WO $46^{\circ} 58^{\prime} 31.9^{\prime \prime}$ \\
\hline B5P2 & Espatódea & S $23^{\circ} 01^{\prime} 53.6^{\prime \prime}$ & WO $46^{\circ} 58^{\prime} 31.8^{\prime \prime}$ \\
\hline B5P2 & Pinus & S $23^{\circ} 01^{\prime} 54.0^{\prime \prime}$ & WO $46^{\circ} 58^{\prime} 38.5^{\prime \prime}$ \\
\hline B5P2 & Pinus & S $23^{\circ} 01^{\prime} 53.8^{\prime \prime}$ & WO $46^{\circ} 58^{\prime} 31.6^{\prime \prime}$ \\
\hline B5P2 & Pinus & $\mathrm{S} 23^{\circ} 01^{\prime} 53.7^{\prime \prime}$ & WO $46^{\circ} 58^{\prime} 31.8^{\prime \prime}$ \\
\hline B5P2 & Espatódea & $\mathrm{S} 23^{\circ} 01^{\prime} 53.8^{\prime \prime}$ & WO $46^{\circ} 58^{\prime} 31.8^{\prime \prime}$ \\
\hline B5P2 & Ipê amarelo & $\mathrm{S} 23^{\circ} 01^{\prime} 53.8^{\prime \prime}$ & WO $46^{\circ} 58^{\prime} 31.7^{\prime \prime}$ \\
\hline B5P2 & Espatódea & $\mathrm{S} 23^{\circ} 01^{\prime} 53.8^{\prime \prime}$ & WO $46^{\circ} 58^{\prime} 31.9^{\prime \prime}$ \\
\hline B5P2 & Ipê amarelo & $\mathrm{S} 23^{\circ} 01^{\prime} 55.4^{\prime \prime}$ & WO $46^{\circ} 58^{\prime} 31.8^{\prime \prime}$ \\
\hline B5P2 & Pinus & S $23^{\circ} 01^{\prime} 54.1^{\prime \prime}$ & WO $46^{\circ} 58^{\prime} 31.9^{\prime \prime}$ \\
\hline B5P2 & Pinus & S $23^{\circ} 01^{\prime} 53.8^{\prime \prime}$ & WO $46^{\circ} 58^{\prime} 31.9^{\prime \prime}$ \\
\hline B5P2 & Pinus & $\mathrm{S} 23^{\circ} 01^{\prime} 53.8^{\prime \prime}$ & WO $46^{\circ} 58^{\prime} 31.8^{\prime \prime}$ \\
\hline B5P2 & Espatódea & $\mathrm{S} 23^{\circ} 01^{\prime} 53.8^{\prime \prime}$ & WO $46^{\circ} 58^{\prime} 31.8^{\prime \prime}$ \\
\hline B5P2 & Ipê amarelo & $\mathrm{S} 23^{\circ} 01^{\prime} 53.9^{\prime \prime}$ & WO $46^{\circ} 58^{\prime} 31.9^{\prime \prime}$ \\
\hline $\mathrm{B} 5 \mathrm{P} 2$ & Pinus & $\mathrm{S} 23^{\circ} 01^{\prime} 54.1^{\prime \prime}$ & WO $46^{\circ} 58^{\prime} 31.9^{\prime \prime}$ \\
\hline
\end{tabular}




\begin{tabular}{|c|c|c|c|}
\hline Praça & Nome Comum & Latitude & Longitude \\
\hline $\mathrm{B} 5 \mathrm{P} 2$ & Ipê amarelo & $\mathrm{S} \mathrm{23^{ \circ } 0 1 ^ { \prime } 5 4 . 0 ^ { \prime \prime }}$ & WO $46^{\circ} 58^{\prime} 31.7^{\prime \prime}$ \\
\hline B5P2 & Ipê amarelo & $\mathrm{S} 23^{\circ} 01^{\prime} 54.1^{\prime \prime}$ & WO $46^{\circ} 58^{\prime} 31.7^{\prime \prime}$ \\
\hline B5P2 & Pinus & $\mathrm{S} 23^{\circ} 01^{\prime} 54.1^{\prime \prime}$ & WO $46^{\circ} 58^{\prime} 31.6^{\prime \prime}$ \\
\hline B5P2 & Pinus & $\mathrm{S} 23^{\circ} 01^{\prime} 54.1^{\prime \prime}$ & WO $46^{\circ} 58^{\prime} 31.7^{\prime \prime}$ \\
\hline $\mathrm{B} 5 \mathrm{P} 2$ & Pinus & $\mathrm{S} 23^{\circ} 01^{\prime} 54.1^{\prime \prime}$ & WO $46^{\circ} 58^{\prime} 31.4^{\prime \prime}$ \\
\hline B5P2 & Pinus & S $23^{\circ} 01^{\prime} 54.2^{\prime \prime}$ & WO $46^{\circ} 58^{\prime} 31.4^{\prime \prime}$ \\
\hline B5P2 & Pinus & $\mathrm{S} 23^{\circ} 01^{\prime} 54.1^{\prime \prime}$ & WO $46^{\circ} 58^{\prime} 31.3^{\prime \prime}$ \\
\hline B5P2 & Pinus & $\mathrm{S} 23^{\circ} 01^{\prime} 54.1^{\prime \prime}$ & WO $46^{\circ} 58^{\prime} 31.3^{\prime \prime}$ \\
\hline B5P2 & Ipê amarelo & $\mathrm{S} 23^{\circ} 01^{\prime} 54.1^{\prime \prime}$ & WO $46^{\circ} 58^{\prime} 31.3^{\prime \prime}$ \\
\hline B5P2 & Espatódea & $\mathrm{S} 23^{\circ} 01^{\prime} 54.3^{\prime \prime}$ & WO 46 $58^{\prime} 31.7^{\prime \prime}$ \\
\hline B5P2 & Ipê amarelo & $\mathrm{S} 23^{\circ} 01^{\prime} 54.3^{\prime \prime}$ & WO $46^{\circ} 58^{\prime} 31.4^{\prime \prime}$ \\
\hline B5P2 & Ipê amarelo & $\mathrm{S} 23^{\circ} 01^{\prime} 54.3^{\prime \prime}$ & WO $46^{\circ} 58^{\prime} 31.4^{\prime \prime}$ \\
\hline B5P2 & Ipê amarelo & $\mathrm{S} 23^{\circ} 01^{\prime} 54.3^{\prime \prime}$ & WO $46^{\circ} 58^{\prime} 31.5^{\prime \prime}$ \\
\hline B5P2 & Pinus & S $23^{\circ} 01^{\prime} 54.4^{\prime \prime}$ & WO 46 58' $31.7^{\prime \prime}$ \\
\hline B5P2 & Pinus & $\mathrm{S} 23^{\circ} 01^{\prime} 54.5^{\prime \prime}$ & WO $46^{\circ} 58^{\prime} 31.6^{\prime \prime}$ \\
\hline B5P2 & Cinamomo & $\mathrm{S} 23^{\circ} 01^{\prime} 54.5^{\prime \prime}$ & WO $46^{\circ} 58^{\prime} 31.6^{\prime \prime}$ \\
\hline B5P2 & Grevília & $\mathrm{S} 23^{\circ} 01^{\prime} 54.5^{\prime \prime}$ & WO $46^{\circ} 58^{\prime} 31.5^{\prime \prime}$ \\
\hline B5P2 & Cinamomo & $\mathrm{S} 23^{\circ} 01^{\prime} 54.6^{\prime \prime}$ & WO $46^{\circ} 58^{\prime} 32.2^{\prime \prime}$ \\
\hline B5P2 & Cinamomo & S $23^{\circ} 01^{\prime} 54.7^{\prime \prime}$ & WO $46^{\circ} 58^{\prime} 32.1^{\prime \prime}$ \\
\hline B5P2 & Aroeira & $\mathrm{S} 23^{\circ} 01^{\prime} 54.7^{\prime \prime}$ & WO $46^{\circ} 58^{\prime} 31.9^{\prime \prime}$ \\
\hline B5P2 & Mangueira & $\mathrm{S} 23^{\circ} 01^{\prime} 54.5^{\prime \prime}$ & WO $46^{\circ} 58^{\prime} 31.9^{\prime \prime}$ \\
\hline B5P2 & Quaresmeira & $\mathrm{S} 23^{\circ} 01^{\prime} 54.6^{\prime \prime}$ & WO $46^{\circ} 58^{\prime} 31.2^{\prime \prime}$ \\
\hline B5P2 & Quaresmeira & S $23^{\circ} 01^{\prime} 54.6^{\prime \prime}$ & WO $46^{\circ} 58^{\prime} 31.1^{\prime \prime}$ \\
\hline B5P2 & Quaresmeira & $\mathrm{S} 23^{\circ} 01^{\prime} 54.8^{\prime \prime}$ & WO $46^{\circ} 58^{\prime} 31.1^{\prime \prime}$ \\
\hline B5P2 & Quaresmeira & $\mathrm{S} 23^{\circ} 01^{\prime} 54.7^{\prime \prime}$ & WO $46^{\circ} 58^{\prime} 31.2^{\prime \prime}$ \\
\hline B5P2 & Paineira & $\mathrm{S} 23^{\circ} 01^{\prime} 54.9^{\prime \prime}$ & WO $46^{\circ} 58^{\prime} 30.8^{\prime \prime}$ \\
\hline B5P2 & Paineira & $\mathrm{S} 23^{\circ} 01^{\prime} 54.8^{\prime \prime}$ & WO 46 $58^{\prime} 30.9^{\prime \prime}$ \\
\hline B5P2 & Paineira & $\mathrm{S} 23^{\circ} 01^{\prime} 54.8^{\prime \prime}$ & WO $46^{\circ} 58^{\prime} 30.9^{\prime \prime}$ \\
\hline B5P2 & Paineira & $\mathrm{S} 23^{\circ} 01^{\prime} 54.8^{\prime \prime}$ & WO $46^{\circ} 58^{\prime} 30.9^{\prime \prime}$ \\
\hline B5P2 & Pinus & S $23^{\circ} 01^{\prime} 54.7^{\prime \prime}$ & WO $46^{\circ} 58^{\prime} 30.9^{\prime \prime}$ \\
\hline B5P2 & Amoreira & S $23^{\circ} 01^{\prime} 54.9^{\prime \prime}$ & WO $46^{\circ} 58^{\prime} 30.6^{\prime \prime}$ \\
\hline B5P2 & Amoreira & $\mathrm{S} 23^{\circ} 01^{\prime} 54.5^{\prime \prime}$ & WO $46^{\circ} 58^{\prime} 30.6^{\prime \prime}$ \\
\hline B5P2 & Amoreira & $\mathrm{S} 23^{\circ} 01^{\prime} 54.5^{\prime \prime}$ & WO $46^{\circ} 58^{\prime} 30.9^{\prime \prime}$ \\
\hline B5P2 & Aceroleira & $\mathrm{S} 23^{\circ} 01^{\prime} 54.0^{\prime \prime}$ & WO $46^{\circ} 58^{\prime} 30.6^{\prime \prime}$ \\
\hline B5P2 & Não identificada & $\mathrm{S} 23^{\circ} 01^{\prime} 53.9^{\prime \prime}$ & WO $46^{\circ} 58^{\prime} 30.8^{\prime \prime}$ \\
\hline B5P2 & Não identificada & $\mathrm{S} 23^{\circ} 01^{\prime} 53.8^{\prime \prime}$ & WO $46^{\circ} 58^{\prime} 30.9^{\prime \prime}$ \\
\hline B5P2 & Paineira & $\mathrm{S} 23^{\circ} 01^{\prime} 55.7^{\prime \prime}$ & WO $46^{\circ} 58^{\prime} 30.6^{\prime \prime}$ \\
\hline B5P2 & Pinus & $\mathrm{S} 23^{\circ} 01^{\prime} 55.0^{\prime \prime}$ & WO $46^{\circ} 58^{\prime} 31.0^{\prime \prime}$ \\
\hline B5P2 & Pinus & S $23^{\circ} 01^{\prime} 54.9^{\prime \prime}$ & WO $46^{\circ} 58^{\prime} 30.7^{\prime \prime}$ \\
\hline B5P2 & Pinus & $\mathrm{S} 23^{\circ} 01^{\prime} 54.9^{\prime \prime}$ & WO $46^{\circ} 58^{\prime} 30.6^{\prime \prime}$ \\
\hline B5P2 & Pinus & $\mathrm{S} 23^{\circ} 01^{\prime} 54.5^{\prime \prime}$ & WO $46^{\circ} 58^{\prime} 30.6^{\prime \prime}$ \\
\hline B5P2 & Pinus & $\mathrm{S} 23^{\circ} 01^{\prime} 54.2^{\prime \prime}$ & WO $46^{\circ} 58^{\prime} 30.7^{\prime \prime}$ \\
\hline B5P2 & Pinus & $\mathrm{S} 23^{\circ} 01^{\prime} 54.2^{\prime \prime}$ & WO $46^{\circ} 58^{\prime} 30.7^{\prime \prime}$ \\
\hline B5P2 & Pinus & S $23^{\circ} 01^{\prime} 55.4^{\prime \prime}$ & WO $46^{\circ} 58^{\prime} 30.8^{\prime \prime}$ \\
\hline B5P2 & Pinus & $\mathrm{S} 23^{\circ} 01^{\prime} 55.2^{\prime \prime}$ & WO 46 $58^{\prime} 30.7^{\prime \prime}$ \\
\hline B5P2 & Pinus & $\mathrm{S} 23^{\circ} 01^{\prime} 55.1^{\prime \prime}$ & WO 46 $58^{\prime} 30.6^{\prime \prime}$ \\
\hline B5P2 & Pinus & $\mathrm{S} 23^{\circ} 01^{\prime} 55.4^{\prime \prime}$ & WO $46^{\circ} 58^{\prime} 30.5^{\prime \prime}$ \\
\hline B5P2 & Pinus & $\mathrm{S} 23^{\circ} 01^{\prime} 55.5^{\prime \prime}$ & WO $46^{\circ} 58^{\prime} 30.0^{\prime \prime}$ \\
\hline B5P2 & Pinus & $\mathrm{S} 23^{\circ} 01^{\prime} 55.1^{\prime \prime}$ & WO $46^{\circ} 58^{\prime} 30.3^{\prime \prime}$ \\
\hline B5P2 & Pinus & $\mathrm{S} 23^{\circ} 01^{\prime} 55.0^{\prime \prime}$ & WO $46^{\circ} 58^{\prime} 30.4^{\prime \prime}$ \\
\hline
\end{tabular}




\begin{tabular}{|c|c|c|c|}
\hline Praça & Nome Comum & Latitude & Longitude \\
\hline $\mathrm{B} 5 \mathrm{P} 2$ & Paineira & 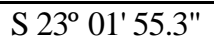 & WO $46^{\circ} 58^{\prime} 31.0^{\prime \prime}$ \\
\hline B5P2 & Pinus & $\mathrm{S} 23^{\circ} 01^{\prime} 55.3^{\prime \prime}$ & WO $46^{\circ} 58^{\prime} 30.7^{\prime \prime}$ \\
\hline B5P2 & Pinus & $\mathrm{S} 23^{\circ} 01^{\prime} 55.5^{\prime \prime}$ & WO $46^{\circ} 58^{\prime} 30.4^{\prime \prime}$ \\
\hline B5P2 & Pinus & $\mathrm{S} 23^{\circ} 01^{\prime} 55.2^{\prime \prime}$ & WO $46^{\circ} 58^{\prime} 30.5^{\prime \prime}$ \\
\hline B5P2 & Pinus & $\mathrm{S} 23^{\circ} 01^{\prime} 55.1^{\prime \prime}$ & WO $46^{\circ} 58^{\prime} 30.5^{\prime \prime}$ \\
\hline B5P2 & Paineira & $\mathrm{S} 23^{\circ} 01^{\prime} 55.3^{\prime \prime}$ & WO $46^{\circ} 58^{\prime} 30.3^{\prime \prime}$ \\
\hline B5P2 & Paineira & $\mathrm{S} 23^{\circ} 01^{\prime} 55.2^{\prime \prime}$ & WO $46^{\circ} 58^{\prime} 30.3^{\prime \prime}$ \\
\hline B5P2 & Pinus & $\mathrm{S} 23^{\circ} 01^{\prime} 55.1^{\prime \prime}$ & WO $46^{\circ} 58^{\prime} 30.5^{\prime \prime}$ \\
\hline B5P2 & Pinus & S $23^{\circ} 01^{\prime} 55.2^{\prime \prime}$ & WO $46^{\circ} 58^{\prime} 30.3^{\prime \prime}$ \\
\hline B5P2 & Pinus & $\mathrm{S} 23^{\circ} 01^{\prime} 55.2^{\prime \prime}$ & WO $46^{\circ} 58^{\prime} 30.5^{\prime \prime}$ \\
\hline B5P2 & Pinus & S $23^{\circ} 01^{\prime} 55.4^{\prime \prime}$ & WO $46^{\circ} 58^{\prime} 30.4^{\prime \prime}$ \\
\hline B5P2 & Pinus & $\mathrm{S} 23^{\circ} 01^{\prime} 55.5^{\prime \prime}$ & WO $46^{\circ} 58^{\prime} 30.2^{\prime \prime}$ \\
\hline B5P2 & Pinus & $\mathrm{S} 23^{\circ} 01^{\prime} 55.5^{\prime \prime}$ & WO $46^{\circ} 58^{\prime} 30.2^{\prime \prime}$ \\
\hline B5P2 & Pinus & $\mathrm{S} 23^{\circ} 01^{\prime} 55.5^{\prime \prime}$ & WO $46^{\circ} 58^{\prime} 30.1^{\prime \prime}$ \\
\hline B5P2 & Pinus & $\mathrm{S} 23^{\circ} 01^{\prime} 55.7^{\prime \prime}$ & WO $46^{\circ} 58^{\prime} 30.0^{\prime \prime}$ \\
\hline B5P2 & Pinus & $\mathrm{S} 23^{\circ} 01^{\prime} 55.8^{\prime \prime}$ & WO $46^{\circ} 58^{\prime} 30.8^{\prime \prime}$ \\
\hline B5P2 & Pinus & S $23^{\circ} 01^{\prime} 55.7^{\prime \prime}$ & WO $46^{\circ} 58^{\prime} 30.2^{\prime \prime}$ \\
\hline B5P2 & Pinus & $\mathrm{S} 23^{\circ} 01^{\prime} 55.8^{\prime \prime}$ & WO $46^{\circ} 58^{\prime} 30.2^{\prime \prime}$ \\
\hline B5P2 & Pinus & $\mathrm{S} 23^{\circ} 01^{\prime} 55.5^{\prime \prime}$ & WO $46^{\circ} 58^{\prime} 30.4^{\prime \prime}$ \\
\hline B5P2 & Pinus & $\mathrm{S} 23^{\circ} 01^{\prime} 55.6^{\prime \prime}$ & WO $46^{\circ} 58^{\prime} 30.3^{\prime \prime}$ \\
\hline B5P2 & Pinus & $\mathrm{S} 23^{\circ} 01^{\prime} 55.6^{\prime \prime}$ & WO $46^{\circ} 58^{\prime} 30.3^{\prime \prime}$ \\
\hline B5P2 & Pinus & $\mathrm{S} 23^{\circ} 01^{\prime} 55.8^{\prime \prime}$ & WO $46^{\circ} 58^{\prime} 30.2^{\prime \prime}$ \\
\hline B5P2 & Pinus & $\mathrm{S} 23^{\circ} 01^{\prime} 55.9^{\prime \prime}$ & WO $46^{\circ} 58^{\prime} 30.2^{\prime \prime}$ \\
\hline B5P2 & Pinus & $\mathrm{S} 23^{\circ} 01^{\prime} 55.8^{\prime \prime}$ & WO $46^{\circ} 58^{\prime} 30.2^{\prime \prime}$ \\
\hline B5P2 & Pinus & $\mathrm{S} 23^{\circ} 01^{\prime} 55.9^{\prime \prime}$ & WO $46^{\circ} 58^{\prime} 30.0^{\prime \prime}$ \\
\hline B5P2 & Espatódea & $\mathrm{S} 23^{\circ} 01^{\prime} 55.9^{\prime \prime}$ & WO $46^{\circ} 58^{\prime} 30.1^{\prime \prime}$ \\
\hline B5P2 & Não identificada & $\mathrm{S} 23^{\circ} 01^{\prime} 55.9^{\prime \prime}$ & WO $46^{\circ} 58^{\prime} 30.0^{\prime \prime}$ \\
\hline B5P2 & Pinus & $\mathrm{S} 23^{\circ} 01^{\prime} 56.1^{\prime \prime}$ & WO $46^{\circ} 58^{\prime} 30.0^{\prime \prime}$ \\
\hline B5P2 & Quaresmeira & $\mathrm{S} 23^{\circ} 01^{\prime} 56.5^{\prime \prime}$ & WO $46^{\circ} 58^{\prime} 30.1^{\prime \prime}$ \\
\hline B5P2 & Quaresmeira & S $23^{\circ} 01^{\prime} 56.6^{\prime \prime}$ & WO $46^{\circ} 58^{\prime} 30.1^{\prime \prime}$ \\
\hline B5P2 & Ipê amarelo & $\mathrm{S} 23^{\circ} 01^{\prime} 56.5^{\prime \prime}$ & WO $46^{\circ} 58^{\prime} 30.1^{\prime \prime}$ \\
\hline B5P2 & Ipê amarelo & $\mathrm{S} 23^{\circ} 01^{\prime} 55.3^{\prime \prime}$ & WO $46^{\circ} 58^{\prime} 30.3^{\prime \prime}$ \\
\hline B5P2 & Paineira & $\mathrm{S} 23^{\circ} 01^{\prime} 55.8^{\prime \prime}$ & WO $46^{\circ} 58^{\prime} 30.1^{\prime \prime}$ \\
\hline B5P2 & Pinus & $\mathrm{S} 23^{\circ} 01^{\prime} 55.6^{\prime \prime}$ & WO $46^{\circ} 58^{\prime} 30.3^{\prime \prime}$ \\
\hline B5P2 & Paineira & S $23^{\circ} 01^{\prime} 55.6^{\prime \prime}$ & WO $46^{\circ} 58^{\prime} 30.5^{\prime \prime}$ \\
\hline B5P2 & Ipê amarelo & $\mathrm{S} 23^{\circ} 01^{\prime} 55.8^{\prime \prime}$ & WO $46^{\circ} 58^{\prime} 30.7^{\prime \prime}$ \\
\hline B5P2 & Ipê amarelo & S $23^{\circ} 01^{\prime} 53.2^{\prime \prime}$ & WO $46^{\circ} 58^{\prime} 30.5^{\prime \prime}$ \\
\hline B5P2 & Ipê amarelo & $\mathrm{S} 23^{\circ} 01^{\prime} 56.1^{\prime \prime}$ & WO $46^{\circ} 58^{\prime} 30.6^{\prime \prime}$ \\
\hline B5P2 & Paineira & S $23^{\circ} 01^{\prime} 55.7^{\prime \prime}$ & WO $46^{\circ} 58^{\prime} 30.4^{\prime \prime}$ \\
\hline B5P2 & Ipê amarelo & $\mathrm{S} 23^{\circ} 01^{\prime} 55.9^{\prime \prime}$ & WO $46^{\circ} 58^{\prime} 30.4^{\prime \prime}$ \\
\hline B5P2 & Ipê amarelo & S $23^{\circ} 01^{\prime} 56.2^{\prime \prime}$ & WO $46^{\circ} 58^{\prime} 30.4^{\prime \prime}$ \\
\hline B5P2 & Ipê amarelo & $\mathrm{S} 23^{\circ} 01^{\prime} 56.2^{\prime \prime}$ & WO $46^{\circ} 58^{\prime} 30.3^{\prime \prime}$ \\
\hline B5P2 & Quaresmeira & S $23^{\circ} 01^{\prime} 56.4^{\prime \prime}$ & WO $46^{\circ} 58^{\prime} 30.3^{\prime \prime}$ \\
\hline B5P2 & Ipê amarelo & S $23^{\circ} 01^{\prime} 56.2^{\prime \prime}$ & WO $46^{\circ} 58^{\prime} 30.4^{\prime \prime}$ \\
\hline B5P2 & Pau Brasil & S $23^{\circ} 01^{\prime} 56.4^{\prime \prime}$ & WO $46^{\circ} 58^{\prime} 30.8^{\prime \prime}$ \\
\hline B5P2 & Sibipiruna & $\mathrm{S} 23^{\circ} 01^{\prime} 56.2^{\prime \prime}$ & WO $46^{\circ} 58^{\prime} 31.1^{\prime \prime}$ \\
\hline B5P2 & Quaresmeira & $\mathrm{S} 23^{\circ} 01^{\prime} 56.5^{\prime \prime}$ & WO $46^{\circ} 58^{\prime} 30.5^{\prime \prime}$ \\
\hline B5P2 & Ipê amarelo & $\mathrm{S} 23^{\circ} 01^{\prime} 56.0^{\prime \prime}$ & WO $46^{\circ} 58^{\prime} 31.0^{\prime \prime}$ \\
\hline B5P2 & Ipê amarelo & $\mathrm{S} 23^{\circ} 01^{\prime} 56.3^{\prime \prime}$ & WO $46^{\circ} 58^{\prime} 31.2^{\prime \prime}$ \\
\hline $\mathrm{B} 5 \mathrm{P} 2$ & Pinus & $\mathrm{S} 23^{\circ} 01^{\prime} 53.4^{\prime \prime}$ & WO $46^{\circ} 58^{\prime} 30.5^{\prime \prime}$ \\
\hline
\end{tabular}




\begin{tabular}{|c|c|c|c|}
\hline Praça & Nome Comum & Latitude & Longitude \\
\hline $\mathrm{B} 5 \mathrm{P} 2$ & Jacarandá mimoso & 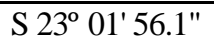 & WO $46^{\circ} 58^{\prime} 30.6^{\prime \prime}$ \\
\hline B5P2 & Ipê amarelo & $\mathrm{S} 23^{\circ} 01^{\prime} 57.2^{\prime \prime}$ & WO $46^{\circ} 58^{\prime} 31.3^{\prime \prime}$ \\
\hline B5P2 & Ipê amarelo & $\mathrm{S} 23^{\circ} 01^{\prime} 58.8^{\prime \prime}$ & WO $46^{\circ} 58^{\prime} 31.4^{\prime \prime}$ \\
\hline B5P2 & Não identificada & S $23^{\circ} 01^{\prime} 56.9^{\prime \prime}$ & WO $46^{\circ} 58^{\prime} 31.6^{\prime \prime}$ \\
\hline B5P2 & Não identificada & $\mathrm{S} 23^{\circ} 01^{\prime} 56.7^{\prime \prime}$ & WO $46^{\circ} 58^{\prime} 31.8^{\prime \prime}$ \\
\hline B5P2 & Ipê amarelo & $\mathrm{S} 23^{\circ} 01^{\prime} 56.9^{\prime \prime}$ & WO $46^{\circ} 58^{\prime} 31.6^{\prime \prime}$ \\
\hline B5P2 & Ipê amarelo & S $23^{\circ} 01^{\prime} 57.2^{\prime \prime}$ & WO $46^{\circ} 58^{\prime} 32.0^{\prime \prime}$ \\
\hline B5P2 & Ipê amarelo & $\mathrm{S} 23^{\circ} 01^{\prime} 57.0^{\prime \prime}$ & WO $46^{\circ} 58^{\prime} 31.8^{\prime \prime}$ \\
\hline B5P2 & Ipê amarelo & S $23^{\circ} 01^{\prime} 57.2^{\prime \prime}$ & WO $46^{\circ} 58^{\prime} 32.2^{\prime \prime}$ \\
\hline B5P2 & Ipê amarelo & S $23^{\circ} 01^{\prime} 57.3^{\prime \prime}$ & WO $46^{\circ} 58^{\prime} 31.9^{\prime \prime}$ \\
\hline B5P2 & Ipê amarelo & S $23^{\circ} 01^{\prime} 57.4^{\prime \prime}$ & WO $46^{\circ} 58^{\prime} 32.0^{\prime \prime}$ \\
\hline B5P2 & Ipê amarelo & $\mathrm{S} 23^{\circ} 01^{\prime} 57.2^{\prime \prime}$ & WO $46^{\circ} 58^{\prime} 32.3^{\prime \prime}$ \\
\hline B5P2 & Ipê amarelo & $\mathrm{S} 23^{\circ} 01^{\prime} 57.3^{\prime \prime}$ & WO $46^{\circ} 58^{\prime} 32.3^{\prime \prime}$ \\
\hline B5P2 & Ipê amarelo & S $23^{\circ} 01^{\prime} 57.4^{\prime \prime}$ & WO $46^{\circ} 58^{\prime} 32.2^{\prime \prime}$ \\
\hline B5P2 & Espatódea & $\mathrm{S} 23^{\circ} 01^{\prime} 56.8^{\prime \prime}$ & WO $46^{\circ} 58^{\prime} 32.0^{\prime \prime}$ \\
\hline B5P2 & Ipê amarelo & $\mathrm{S} 23^{\circ} 01^{\prime} 57.0^{\prime \prime}$ & WO $46^{\circ} 58^{\prime} 32.2^{\prime \prime}$ \\
\hline B5P2 & Jacarandá mimoso & S $23^{\circ} 01^{\prime} 56.9^{\prime \prime}$ & WO $46^{\circ} 58^{\prime} 31.5^{\prime \prime}$ \\
\hline B5P2 & Ipê amarelo & S $23^{\circ} 01^{\prime} 56.6^{\prime \prime}$ & WO $46^{\circ} 58^{\prime} 31.3^{\prime \prime}$ \\
\hline B5P2 & Jerivá & S $23^{\circ} 01^{\prime} 55.7^{\prime \prime}$ & WO $46^{\circ} 58^{\prime} 33.0^{\prime \prime}$ \\
\hline B5P2 & Jerivá & $\mathrm{S} 23^{\circ} 01^{\prime} 55.9^{\prime \prime}$ & WO $46^{\circ} 58^{\prime} 33.1^{\prime \prime}$ \\
\hline B5P3 & Pata de vaca branca & $\mathrm{S} 23^{\circ} 01^{\prime} 58.9^{\prime \prime}$ & WO $46^{\circ} 58^{\prime} 40.6^{\prime \prime}$ \\
\hline B5P3 & Ligustro & $\mathrm{S} 23^{\circ} 01^{\prime} 58.2^{\prime \prime}$ & WO $46^{\circ} 58^{\prime} 40.4^{\prime \prime}$ \\
\hline B5P3 & Pinus & $\mathrm{S} 23^{\circ} 01^{\prime} 57.8^{\prime \prime}$ & WO $46^{\circ} 58^{\prime} 40.6^{\prime \prime}$ \\
\hline B5P3 & Pinus & $\mathrm{S} 23^{\circ} 01^{\prime} 57.7^{\prime \prime}$ & WO $46^{\circ} 58^{\prime} 40.5^{\prime \prime}$ \\
\hline B5P3 & Pinus & $\mathrm{S} 23^{\circ} 01^{\prime} 57.5^{\prime \prime}$ & WO $46^{\circ} 58^{\prime} 40.9^{\prime \prime}$ \\
\hline B5P3 & Não identificada & $\mathrm{S} 23^{\circ} 01^{\prime} 57.4^{\prime \prime}$ & WO $46^{\circ} 58^{\prime} 41.0^{\prime \prime}$ \\
\hline B5P3 & Ligustro & $\mathrm{S} 23^{\circ} 01^{\prime} 57.4^{\prime \prime}$ & WO $46^{\circ} 58^{\prime} 40.4^{\prime \prime}$ \\
\hline B5P3 & Jerivá & $\mathrm{S} 23^{\circ} 01^{\prime} 57.1^{\prime \prime}$ & WO $46^{\circ} 58^{\prime} 41.2^{\prime \prime}$ \\
\hline B5P3 & Jerivá & $\mathrm{S} 23^{\circ} 01^{\prime} 57.1^{\prime \prime}$ & WO $46^{\circ} 58^{\prime} 41.2^{\prime \prime}$ \\
\hline B5P3 & Jerivá & $\mathrm{S} 23^{\circ} 01^{\prime} 57.3^{\prime \prime}$ & WO $46^{\circ} 58^{\prime} 41.3^{\prime \prime}$ \\
\hline B5P3 & Aroeira & $\mathrm{S} 23^{\circ} 01^{\prime} 57.2^{\prime \prime}$ & WO $46^{\circ} 58^{\prime} 41.4^{\prime \prime}$ \\
\hline B5P3 & Jerivá & $\mathrm{S} 23^{\circ} 01^{\prime} 57.6^{\prime \prime}$ & WO $46^{\circ} 58^{\prime} 40.8^{\prime \prime}$ \\
\hline B5P3 & Jerivá & $\mathrm{S} 23^{\circ} 01^{\prime} 59.6^{\prime \prime}$ & WO $46^{\circ} 58^{\prime} 40.6^{\prime \prime}$ \\
\hline B5P3 & Jerivá & $\mathrm{S} 23^{\circ} 01^{\prime} 57.0^{\prime \prime}$ & WO $46^{\circ} 58^{\prime} 41.5^{\prime \prime}$ \\
\hline B5P3 & Jerivá & $\mathrm{S} 23^{\circ} 01^{\prime} 57.0^{\prime \prime}$ & WO $46^{\circ} 58^{\prime} 41.7^{\prime \prime}$ \\
\hline B5P3 & Jerivá & $\mathrm{S} 23^{\circ} 01^{\prime} 56.5^{\prime \prime}$ & WO $46^{\circ} 58^{\prime} 41.4^{\prime \prime}$ \\
\hline B5P3 & Fênix & $\mathrm{S} 23^{\circ} 01^{\prime} 55.8^{\prime \prime}$ & WO $46^{\circ} 58^{\prime} 41.3^{\prime \prime}$ \\
\hline B5P3 & Cinamomo & S $23^{\circ} 01^{\prime} 57.4^{\prime \prime}$ & WO $46^{\circ} 58^{\prime} 41.3^{\prime \prime}$ \\
\hline B5P3 & Fênix & $\mathrm{S} 23^{\circ} 01^{\prime} 56.9^{\prime \prime}$ & WO $46^{\circ} 58^{\prime} 41.3^{\prime \prime}$ \\
\hline B5P3 & Ipê amarelo & $\mathrm{S} 23^{\circ} 01^{\prime} 58.2^{\prime \prime}$ & WO $46^{\circ} 58^{\prime} 40.5^{\prime \prime}$ \\
\hline B5P4 & Ipê amarelo & $\mathrm{S} 23^{\circ} 02^{\prime} 00.2^{\prime \prime}$ & WO $46^{\circ} 58^{\prime} 38.7^{\prime \prime}$ \\
\hline B5P4 & Sibipiruna & $\mathrm{S} 23^{\circ} 02^{\prime} 00.0^{\prime \prime}$ & WO $46^{\circ} 58^{\prime} 38.4^{\prime \prime}$ \\
\hline B5P4 & Sibipiruna & $\mathrm{S} 23^{\circ} 02^{\prime} 00.0^{\prime \prime}$ & WO $46^{\circ} 58^{\prime} 38.4^{\prime \prime}$ \\
\hline B5P4 & Sibipiruna & $\mathrm{S} 23^{\circ} 02^{\prime} 00.1^{\prime \prime}$ & WO $46^{\circ} 58^{\prime} 38.5^{\prime \prime}$ \\
\hline B5P4 & Jacarandá mimoso & $\mathrm{S} 23^{\circ} 02^{\prime} 00.5^{\prime \prime}$ & WO $46^{\circ} 58^{\prime} 38.5^{\prime \prime}$ \\
\hline B5P4 & Sibipiruna & $\mathrm{S} 23^{\circ} 02^{\prime} 00.4^{\prime \prime}$ & WO $46^{\circ} 58^{\prime} 38.5^{\prime \prime}$ \\
\hline B5P4 & Ipê amarelo & $\mathrm{S} 23^{\circ} 02^{\prime} 00.7^{\prime \prime}$ & WO $46^{\circ} 58^{\prime} 38.1^{\prime \prime}$ \\
\hline B5P4 & Sibipiruna & $\mathrm{S} 23^{\circ} 02^{\prime} 00.4^{\prime \prime}$ & WO $46^{\circ} 58^{\prime} 38.5^{\prime \prime}$ \\
\hline B5P4 & Ipê roxo & $\mathrm{S} 23^{\circ} 02^{\prime} 00.2^{\prime \prime}$ & WO $46^{\circ} 58^{\prime} 38.5^{\prime \prime}$ \\
\hline B5P4 & Ipê roxo & $\mathrm{S} 23^{\circ} 01^{\prime} 59.9^{\prime \prime}$ & WO $46^{\circ} 58^{\prime} 38.3^{\prime \prime}$ \\
\hline
\end{tabular}




\begin{tabular}{|c|c|c|c|}
\hline Praça & Nome Comum & Latitude & Longitude \\
\hline $\mathrm{B} 5 \mathrm{P} 4$ & Ipê amarelo & ${\mathrm{S} 23^{\circ} 02^{\prime} 00.4^{\prime \prime}}$ & WO $46^{\circ} 58^{\prime} 37.6^{\prime \prime}$ \\
\hline B5P4 & Ipê amarelo & $\mathrm{S} 23^{\circ} 02^{\prime} 00.9^{\prime \prime}$ & WO $46^{\circ} 58^{\prime} 37.6^{\prime \prime}$ \\
\hline B5P4 & Ipê amarelo & S $23^{\circ} 01^{\prime} 59.9^{\prime \prime}$ & WO $46^{\circ} 58^{\prime} 38.9^{\prime \prime}$ \\
\hline B6P1 & Jacarandá mimoso & $\mathrm{S} 23^{\circ} 00^{\prime} 52.0^{\prime \prime}$ & WO $46^{\circ} 59^{\prime} 29.6^{\prime \prime}$ \\
\hline B6P1 & Pau ferro & $\mathrm{S} 23^{\circ} 00^{\prime} 52.0^{\prime \prime}$ & WO $46^{\circ} 59^{\prime} 29.6^{\prime \prime}$ \\
\hline B6P1 & Pata de vaca & $\mathrm{S} 23^{\circ} 00^{\prime} 51.7^{\prime \prime}$ & WO 46 $59^{\prime} 29.6^{\prime \prime}$ \\
\hline B6P1 & Não identificada & $\mathrm{S} 23^{\circ} 00^{\prime} 51.5^{\prime \prime}$ & WO $46^{\circ} 59^{\prime} 29.2^{\prime \prime}$ \\
\hline B6P1 & Quaresmeira & $\mathrm{S} 23^{\circ} 00^{\prime} 50.9^{\prime \prime}$ & WO $46^{\circ} 59^{\prime} 29.7^{\prime \prime}$ \\
\hline B6P1 & Não identificada & $\mathrm{S} 23^{\circ} 00^{\prime} 51.7^{\prime \prime}$ & WO $46^{\circ} 59^{\prime} 29.9^{\prime \prime}$ \\
\hline B6P1 & Não identificada & $\mathrm{S} 23^{\circ} 00^{\prime} 51.7^{\prime \prime}$ & WO $46^{\circ} 59^{\prime} 29.8^{\prime \prime}$ \\
\hline B6P1 & Não identificada & $\mathrm{S} 23^{\circ} 00^{\prime} 51.5^{\prime \prime}$ & WO $46^{\circ} 59^{\prime} 29.8^{\prime \prime}$ \\
\hline B6P1 & Não identificada & $\mathrm{S} 23^{\circ} 00^{\prime} 51.1^{\prime \prime}$ & WO $46^{\circ} 59^{\prime} 29.8^{\prime \prime}$ \\
\hline B6P1 & Não identificada & $\mathrm{S} 23^{\circ} 00^{\prime} 51.1^{\prime \prime}$ & WO $46^{\circ} 59^{\prime} 30.2^{\prime \prime}$ \\
\hline B6P1 & Mangueira & $\mathrm{S} 23^{\circ} 00^{\prime} 51.5^{\prime \prime}$ & WO $46^{\circ} 59^{\prime} 30.2^{\prime \prime}$ \\
\hline B6P1 & Não identificada & $\mathrm{S} 23^{\circ} 00^{\prime} 51.1^{\prime \prime}$ & WO $46^{\circ} 59^{\prime} 30.3^{\prime \prime}$ \\
\hline B6P1 & Não identificada & $\mathrm{S} 23^{\circ} 00^{\prime} 51.1^{\prime \prime}$ & WO $46^{\circ} 59^{\prime} 30.5^{\prime \prime}$ \\
\hline B6P1 & Quaresmeira & $\mathrm{S} 23^{\circ} 00^{\prime} 50.9^{\prime \prime}$ & WO $46^{\circ} 59^{\prime} 30.3^{\prime \prime}$ \\
\hline B6P1 & Quaresmeira & $\mathrm{S} 23^{\circ} 00^{\prime} 50.8^{\prime \prime}$ & WO $46^{\circ} 59^{\prime} 30.3^{\prime \prime}$ \\
\hline B6P1 & Não identificada & $\mathrm{S} 23^{\circ} 00^{\prime} 51.0^{\prime \prime}$ & WO $46^{\circ} 59^{\prime} 30.5^{\prime \prime}$ \\
\hline B6P1 & Não identificada & $\mathrm{S} 23^{\circ} 00^{\prime} 50.0^{\prime \prime}$ & WO $46^{\circ} 59^{\prime} 30.4^{\prime \prime}$ \\
\hline B6P1 & Não identificada & $\mathrm{S} 23^{\circ} 00^{\prime} 50.0^{\prime \prime}$ & WO $46^{\circ} 59^{\prime} 30.3^{\prime \prime}$ \\
\hline B6P1 & Pau ferro & $\mathrm{S} 23^{\circ} 00^{\prime} 50.8^{\prime \prime}$ & WO $46^{\circ} 59^{\prime} 30.5^{\prime \prime}$ \\
\hline B6P1 & Não identificada & $\mathrm{S} 23^{\circ} 00^{\prime} 50.1^{\prime \prime}$ & WO $46^{\circ} 59^{\prime} 29.6^{\prime \prime}$ \\
\hline B6P1 & Pau ferro & $\mathrm{S} 23^{\circ} 00^{\prime} 50.3^{\prime \prime}$ & WO $46^{\circ} 59^{\prime} 29.8^{\prime \prime}$ \\
\hline B6P1 & Pau ferro & $\mathrm{S} 23^{\circ} 00^{\prime} 50.4^{\prime \prime}$ & WO $46^{\circ} 59^{\prime} 29.1^{\prime \prime}$ \\
\hline B6P1 & Pau ferro & $\mathrm{S} 23^{\circ} 00^{\prime} 50.5^{\prime \prime}$ & WO $46^{\circ} 59^{\prime} 29.6^{\prime \prime}$ \\
\hline B6P1 & Não identificada & $\mathrm{S} 23^{\circ} 00^{\prime} 50.5^{\prime \prime}$ & WO $46^{\circ} 59^{\prime} 29.5^{\prime \prime}$ \\
\hline B6P2 & Ligustro & $\mathrm{S} 23^{\circ} 01^{\prime} 01.2^{\prime \prime}$ & WO $46^{\circ} 59^{\prime} 28.8^{\prime \prime}$ \\
\hline B6P2 & Ligustro & $\mathrm{S} 23^{\circ} 01^{\prime} 01.1^{\prime \prime}$ & WO $46^{\circ} 59^{\prime} 28.7^{\prime \prime}$ \\
\hline B6P2 & Não identificada & $\mathrm{S} 23^{\circ} 01^{\prime} 01.0^{\prime \prime}$ & WO $46^{\circ} 59^{\prime} 28.5^{\prime \prime}$ \\
\hline B6P2 & Ligustro & $\mathrm{S} 23^{\circ} 01^{\prime} 01.1^{\prime \prime}$ & WO $46^{\circ} 59^{\prime} 28.5^{\prime \prime}$ \\
\hline B6P2 & Ligustro & $\mathrm{S} 23^{\circ} 01^{\prime} 00.5^{\prime \prime}$ & WO $46^{\circ} 59^{\prime} 28.2^{\prime \prime}$ \\
\hline B6P2 & Ligustro & $\mathrm{S} 23^{\circ} 01^{\prime} 00.7^{\prime \prime}$ & WO $46^{\circ} 59^{\prime} 28.5^{\prime \prime}$ \\
\hline B6P2 & Ligustro & $\mathrm{S} 23^{\circ} 01^{\prime} 00.5^{\prime \prime}$ & WO $46^{\circ} 59^{\prime} 28.9^{\prime \prime}$ \\
\hline B6P2 & Ligustro & $\mathrm{S} 23^{\circ} 01^{\prime} 00.6^{\prime \prime}$ & WO $46^{\circ} 59^{\prime} 29.7^{\prime \prime}$ \\
\hline B7P1 & Figueira benjamina & $\mathrm{S} 23^{\circ} 02^{\prime} 38.4^{\prime \prime}$ & WO $47^{\circ} 00^{\prime} 48.8^{\prime \prime}$ \\
\hline B7P1 & Figueira benjamina & $\mathrm{S} 23^{\circ} 02^{\prime} 38.4^{\prime \prime}$ & WO $47^{\circ} 00^{\prime} 48.4^{\prime \prime}$ \\
\hline B7P1 & Chapéu de napoleão & $\mathrm{S} 23^{\circ} 02^{\prime} 38.4^{\prime \prime}$ & WO $47^{\circ} 00^{\prime} 48.8^{\prime \prime}$ \\
\hline B8P1 & Pau ferro & $\mathrm{S} 23^{\circ} 02^{\prime} 31.6^{\prime \prime}$ & WO $47^{\circ} 00^{\prime} 32.2^{\prime \prime}$ \\
\hline B8P1 & Pau ferro & $\mathrm{S} 23^{\circ} 02^{\prime} 30.4^{\prime \prime}$ & WO $47^{\circ} 00^{\prime} 33.6^{\prime \prime}$ \\
\hline B8P1 & Ipê amarelo & $\mathrm{S} 23^{\circ} 02^{\prime} 30.3^{\prime \prime}$ & WO $47^{\circ} 00^{\prime} 33.9^{\prime \prime}$ \\
\hline B8P1 & Ipê amarelo & $\mathrm{S} 23^{\circ} 02^{\prime} 30.6^{\prime \prime}$ & WO $47^{\circ} 00^{\prime} 34.5^{\prime \prime}$ \\
\hline B8P1 & Ipê amarelo & $\mathrm{S} 23^{\circ} 02^{\prime} 31.0^{\prime \prime}$ & WO $47^{\circ} 00^{\prime} 34.0^{\prime \prime}$ \\
\hline B8P1 & Aroeira & $\mathrm{S} 23^{\circ} 02^{\prime} 32.3^{\prime \prime}$ & WO $47^{\circ} 00^{\prime} 34.4^{\prime \prime}$ \\
\hline B8P1 & Aroeira & $\mathrm{S} 23^{\circ} 02^{\prime} 31.7^{\prime \prime}$ & WO $47^{\circ} 00^{\prime} 34.2^{\prime \prime}$ \\
\hline B8P1 & Aroeira & $\mathrm{S} 23^{\circ} 02^{\prime} 31.7^{\prime \prime}$ & WO $47^{\circ} 00^{\prime} 34.1^{\prime \prime}$ \\
\hline B8P1 & Aroeira & $\mathrm{S} 23^{\circ} 02^{\prime} 31.8^{\prime \prime}$ & WO $47^{\circ} 00^{\prime} 34.0^{\prime \prime}$ \\
\hline B8P1 & Aroeira & $\mathrm{S} 23^{\circ} 02^{\prime} 31.9^{\prime \prime}$ & WO $47^{\circ} 00^{\prime} 34.6^{\prime \prime}$ \\
\hline B8P1 & Jabuticabeira & $\mathrm{S} 23^{\circ} 02^{\prime} 31.7^{\prime \prime}$ & WO $47^{\circ} 00^{\prime} 34.1^{\prime \prime}$ \\
\hline B8P1 & Jabuticabeira & $\mathrm{S} 23^{\circ} 02^{\prime} 31.8^{\prime \prime}$ & WO $47^{\circ} 00^{\prime} 34.0^{\prime \prime}$ \\
\hline
\end{tabular}




\begin{tabular}{|c|c|c|c|}
\hline Praça & Nome Comum & Latitude & Longitude \\
\hline B8P1 & Jabuticabeira & 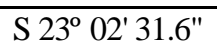 & WO $47^{\circ} 00^{\prime} 34.1^{\prime \prime}$ \\
\hline B8P1 & Jabuticabeira & S $23^{\circ} 02^{\prime} 31.8^{\prime \prime}$ & WO $47^{\circ} 00^{\prime} 34.0^{\prime \prime}$ \\
\hline B8P1 & Jabuticabeira & S $23^{\circ} 02^{\prime} 32.0^{\prime \prime}$ & WO $47^{\circ} 00^{\prime} 34.1^{\prime \prime}$ \\
\hline B8P1 & Aroeira & S $23^{\circ} 02^{\prime} 31.9^{\prime \prime}$ & WO $47^{\circ} 00^{\prime} 34.0^{\prime \prime}$ \\
\hline B8P1 & Jerivá & S $23^{\circ} 02^{\prime} 30.5^{\prime \prime}$ & WO $47^{\circ} 00^{\prime} 33.7^{\prime \prime}$ \\
\hline B8P1 & Jerivá & $\mathrm{S} 23^{\circ} 02^{\prime} 30.9^{\prime \prime}$ & WO $47^{\circ} 00^{\prime} 33.2^{\prime \prime}$ \\
\hline B8P1 & Jerivá & S $23^{\circ} 02^{\prime} 32.3^{\prime \prime}$ & WO $47^{\circ} 00^{\prime} 34.0^{\prime \prime}$ \\
\hline B8P1 & Ipê amarelo & S $23^{\circ} 02^{\prime} 33.7^{\prime \prime}$ & WO $47^{\circ} 00^{\prime} 34.1^{\prime \prime}$ \\
\hline B8P1 & Pau ferro & S $23^{\circ} 02^{\prime} 33.7^{\prime \prime}$ & WO $47^{\circ} 00^{\prime} 33.0^{\prime \prime}$ \\
\hline B8P1 & Ligustro & $\mathrm{S} 23^{\circ} 02^{\prime} 33.7^{\prime \prime}$ & WO $47^{\circ} 00^{\prime} 30.2^{\prime \prime}$ \\
\hline B8P1 & Eucalipto & $\mathrm{S} 23^{\circ} 02^{\prime} 33.5^{\prime \prime}$ & WO $47^{\circ} 00^{\prime} 29.4^{\prime \prime}$ \\
\hline B8P1 & Eucalipto & $\mathrm{S} 23^{\circ} 02^{\prime} 33.5^{\prime \prime}$ & WO $47^{\circ} 00^{\prime} 29.4^{\prime \prime}$ \\
\hline B8P1 & Ligustro & S $23^{\circ} 02^{\prime} 33.7^{\prime \prime}$ & WO $47^{\circ} 00^{\prime} 30.1^{\prime \prime}$ \\
\hline B8P1 & Ligustro & S $23^{\circ} 02^{\prime} 33.7^{\prime \prime}$ & WO $47^{\circ} 00^{\prime} 30.0^{\prime \prime}$ \\
\hline B8P1 & Ligustro & S $23^{\circ} 02^{\prime} 34.2^{\prime \prime}$ & WO $47^{\circ} 00^{\prime} 29.6^{\prime \prime}$ \\
\hline B8P1 & Ligustro & S $23^{\circ} 02^{\prime} 34.3^{\prime \prime}$ & WO $47^{\circ} 00^{\prime} 29.9^{\prime \prime}$ \\
\hline B8P1 & Ligustro & S $23^{\circ} 02^{\prime} 34.5^{\prime \prime}$ & WO $47^{\circ} 00^{\prime} 29.3^{\prime \prime}$ \\
\hline B8P1 & Ligustro & S $23^{\circ} 02^{\prime} 34.6^{\prime \prime}$ & WO $47^{\circ} 00^{\prime} 29.1^{\prime \prime}$ \\
\hline B8P1 & Ligustro & S $23^{\circ} 02^{\prime} 34.7^{\prime \prime}$ & WO $47^{\circ} 00^{\prime} 29.3^{\prime \prime}$ \\
\hline
\end{tabular}

* Para nomes científicos vide Tabela 5

**Árvores que foram removidas durante a realização do inventário 